\title{
Geochemical and Isotopic Interpretations of Groundwater Flow in the Oasis Valley Flow System, Southern Nevada
}

\author{
prepared by \\ J.M. Thomas, F.C. Benedict Jr., T.P. Rose, R.L. Hershey, J.B. Paces, Z.E. Peterman, \\ I.M. Farnham, K.H. Johannesson, A.K. Singh, K.J. Stetzenbach, G.B. Hudson, J.M. Kenneally, \\ G.F. Eaton, and D.K. Smith
}

\author{
submitted to \\ Nevada Operations Office \\ National Nuclear Security Administration \\ U.S. Department of Energy \\ Las Vegas, Nevada
}

August 2002

Publication No. 45190 
Reference herein to any specific commercial product, process, or service by trade name, trademark, manufacturer, or otherwise, does not necessarily constitute or imply its endorsement, recommendation, or favoring by the United States Government or any agency thereof or its contractors or subcontractors. The views and opinions of authors expressed herein do not necessarily state or reflect those of the United States Government or any agency thereof.

This report has been reproduced directly from the best available copy.

Available for sale to the public, in paper, from:

\author{
U.S. Department of Commerce \\ National Technical Information Service \\ 5285 Port Royal Rd. \\ Springfield, VA 22161 \\ phone: 800.553 .6847 \\ fax: 703.605.6000 \\ email: order@ntis.fedworld.gov \\ online ordering: http://www.ntis.gov/ordering.htm
}

Available electronically at http://www.doe.gov/bridge

Available for a processing fee to the U.S. Department of Energy and its contractors, in paper, from:

\author{
U.S. Department of Energy \\ Office of Scientific and Technical Information \\ P.O. Box 62 \\ Oak Ridge, TN 37831-0062 \\ phone: 423.576.8401 \\ fax: 423.576.5728 \\ email: reports@adonis.osti.gov
}




\title{
Geochemical and Isotopic Interpretations of Groundwater Flow in the Oasis Valley Flow System, Southern Nevada
}

\author{
prepared by \\ J.M. Thomas ${ }^{1}$, F.C. Benedict Jr. ${ }^{2}$, T.P. Rose ${ }^{3}$, R.L. Hershey ${ }^{1}$, J.B. Paces ${ }^{4}$, Z.E. Peterman ${ }^{4}$, \\ I.M. Farnham ${ }^{5}$, K.H. Johannesson ${ }^{5}$, A.K. Singh ${ }^{6}$, K.J. Stetzenbach ${ }^{5}$, G.B. Hudson ${ }^{3}$, \\ M. Kenneally ${ }^{3}$, G.F. Eaton ${ }^{3}$, and D.K. Smith ${ }^{3}$
}

Publication No. 45190

Submitted to

Nevada Operations Office

National Nuclear Security Administration

U.S. Department of Energy

Las Vegas, Nevada

August 2002

\footnotetext{
${ }^{1}$ Desert Research Institute, University and Community College System of Nevada

${ }^{2}$ Geotrans Inc., Reno, NV

${ }^{3}$ Analytical and Nuclear Chemistry Division, Lawrence Livermore National Laboratory, Livermore, CA

${ }^{4}$ U.S. Geological Survey, Denver, CO

${ }^{5}$ Harry Reid Center for Environmental Studies, University of Nevada, Las Vegas

${ }^{6}$ Department of Mathematical Sciences, University of Nevada, Las Vegas
} Contract \#DE-AC08-95NV11508. Approved for public release; further dissemination unlimited. 


\section{Executive Summary}

This report summarizes the findings of a geochemical investigation of the Pahute MesaOasis Valley groundwater flow system in southwestern Nevada, funded by the Underground Test Area project of the U.S. Department of Energy, National Nuclear Security Administration Nevada Operations Office. This work is intended to provide geochemical data and interpretations in support of flow and contaminant transport modeling for the Western and Central Pahute Mesa Corrective Action Units. The principal conclusions of this study are as follows:

$>$ Geochemical and isotopic data in the Oasis Valley flow system are consistent with a direct groundwater flowpath between Pahute Mesa and Oasis Valley. This conclusion is in accord with hydraulic gradients and current hydrogeologic framework models of the area.

$>$ The geochemical and isotopic data indicate that groundwater discharge in central Oasis Valley consists predominantly of deep regional groundwater flow beneath Pahute Mesa mixed with a smaller amount of local recharge. Geochemical signatures in the Oasis Valley discharge area are further affected by shallow groundwater recirculation or gas exchange through the unsaturated zone.

$>$ Available data suggest that groundwater in northwestern Oasis Valley originates from north of Oasis Valley, and that groundwater from southeastern Pahute Mesa flows both into the Beatty Wash area of Oasis Valley and down Fortymile Canyon.

$>$ The lack of tritium in groundwater indicates that travel times from Pahute Mesa to Oasis Valley are greater than 50 years.

$>$ Corrected dissolved inorganic carbon and dissolved organic carbon ${ }^{14} \mathrm{C}$ groundwater ages indicate that average travel times from Pahute Mesa to Oasis Valley range from modern (greater than 50 years) to 8,500 years.

$>$ Trace element data and $\mathrm{U}$ and $\mathrm{Sr}$ isotopic data are consistent with the proposed source areas, flowpaths, and mixing of groundwaters that discharge in Oasis Valley. 


\section{Contents}

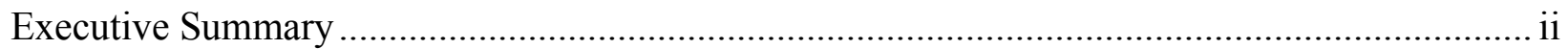

List of Oversized Figures Located in the Back of the Report................................................... v

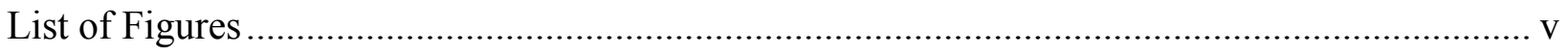

List of Tables Located in the Back of the Report ...................................................................... vii

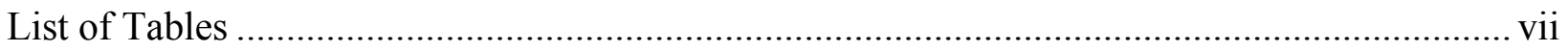

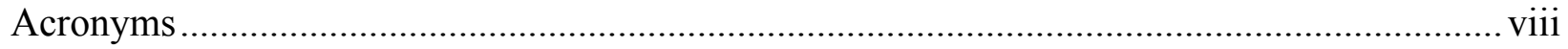

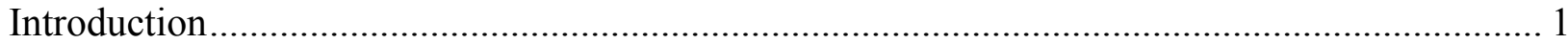

Chapter 1: Hydrogeologic Framework of the Pahute Mesa - Oasis Valley Flow System: Effects of Fracture-coating Mineral Phases on Groundwater Composition .................................... 2

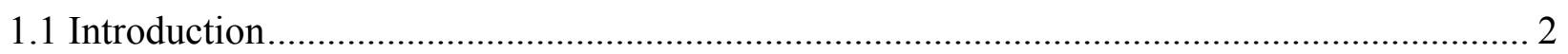

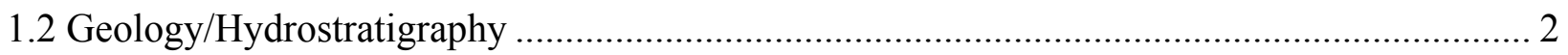

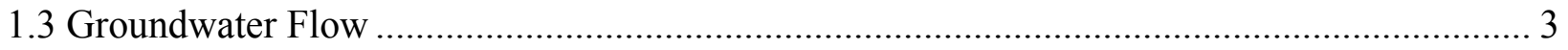

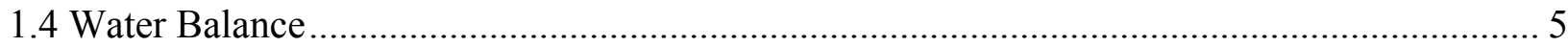

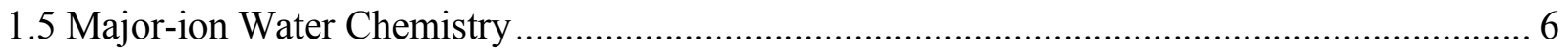

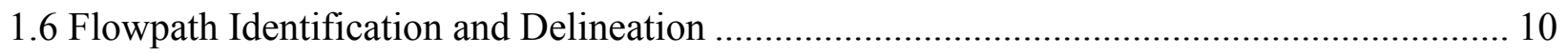

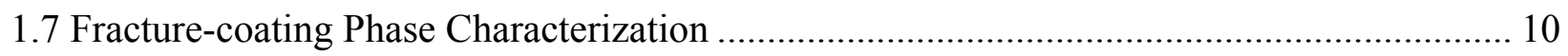

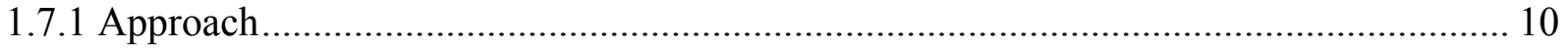

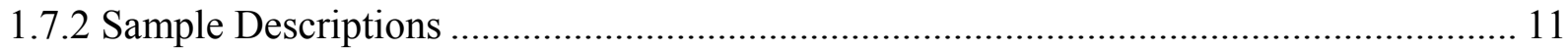

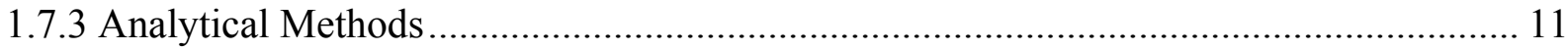

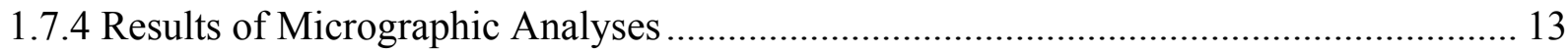

1.8 Results of Isotopic Analyses of Fracture-coating Calcite .................................................... 18

1.8.1 Stable Isotope Results - Distinction Between Saturated and Unsaturated Conditions ... 18

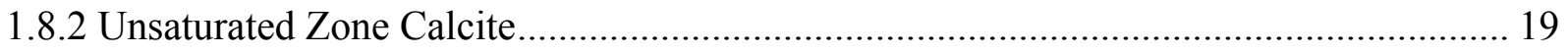

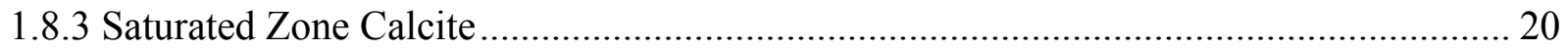

1.8.4 Paleo-temperature Estimates from Calcite $\delta^{18} \mathrm{O}$ Results .............................................. 20

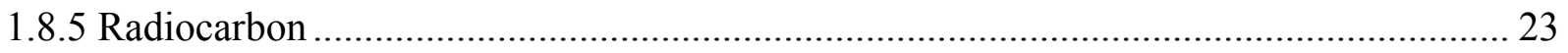

1.9 Summary

Chapter 2: Chemical and Isotopic Composition of Groundwater Recharge to the Oasis Valley

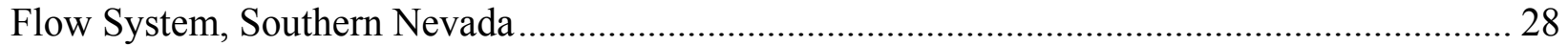

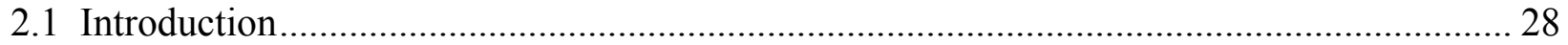

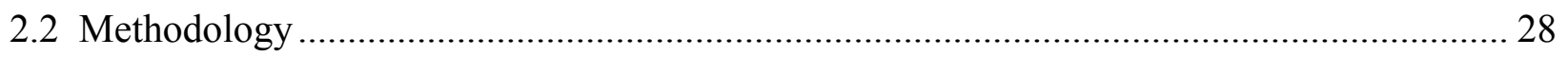

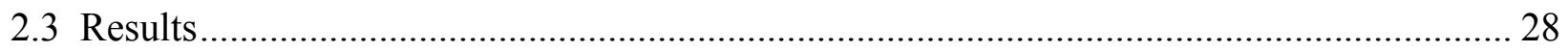


2.3.1 Chemical and Isotopic Composition of Precipitation .................................................. 28

2.3.2 Chemical and Isotopic Composition of Groundwater Recharge ................................... 34

2.3.2.1 Kawich Range and Cactus Range ....................................................................... 34

2.3.2.2 Pahute Mesa and Timber Mountain ..................................................................... 36

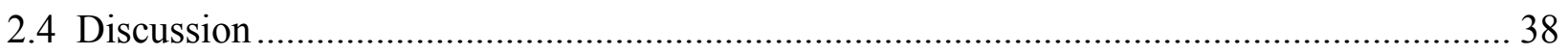

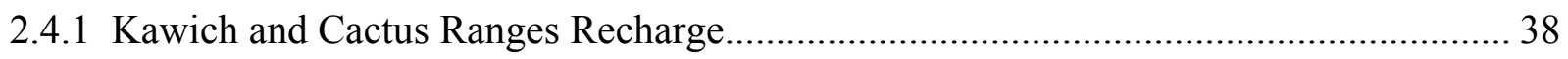

2.4.2 Pahute Mesa Recharge .......................................................................................... 39

2.4.3 Comparison of Recent Recharge to Groundwater ........................................................ 40

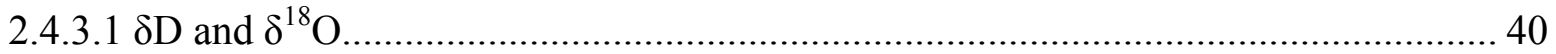

2.4.3.2. Major-ion Chemistry …………………………………………………..... 41

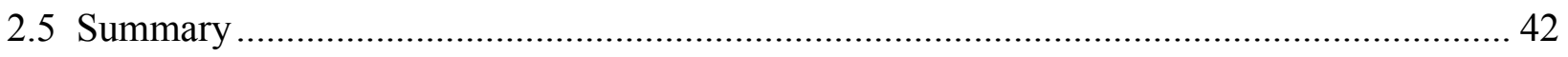

Chapter 3: Groundwater Geochemistry - Analytical Results ................................................... 44

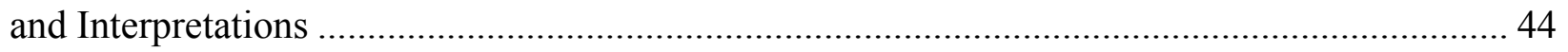

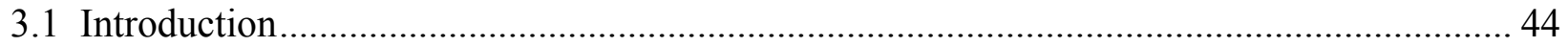

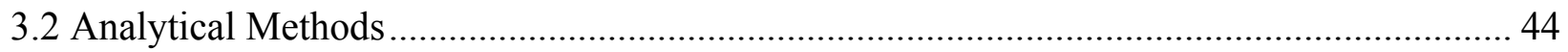

3.2.1 Stable Isotopes of Hydrogen and Oxygen ............................................................. 44

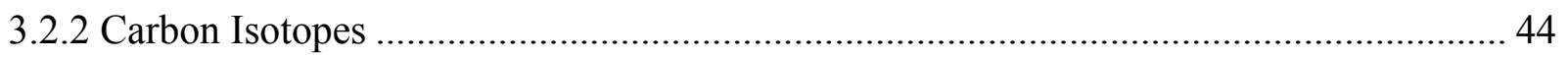

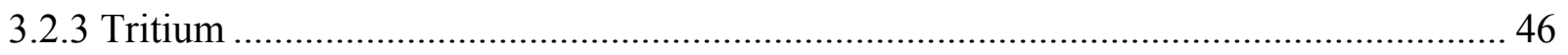

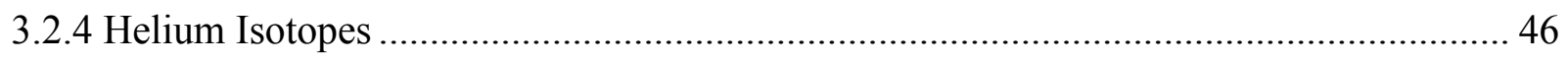

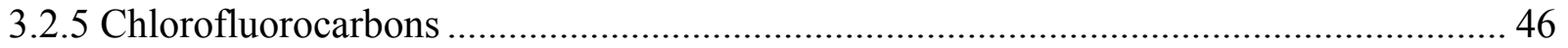

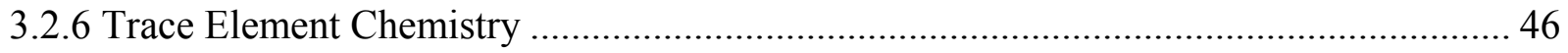

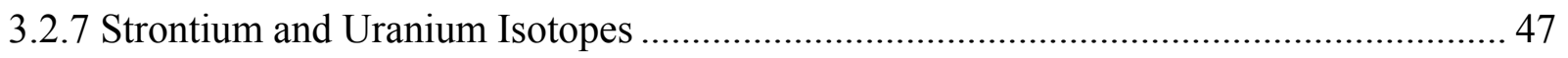

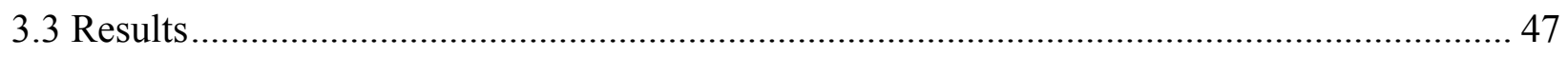

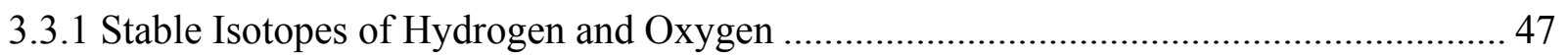

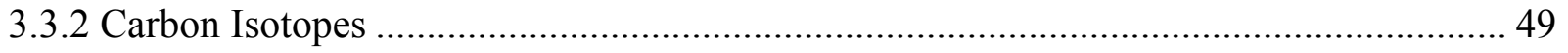

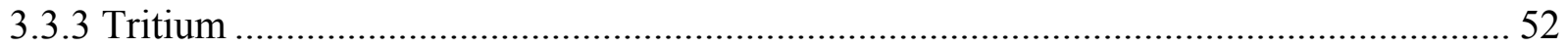

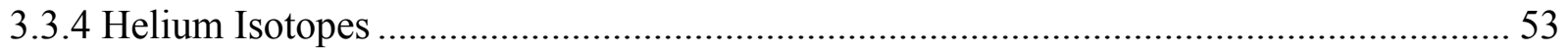

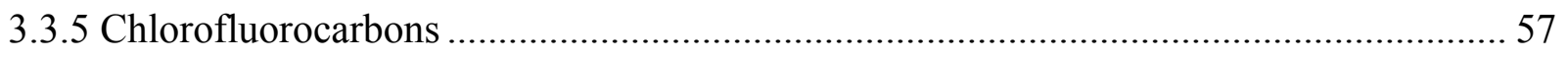

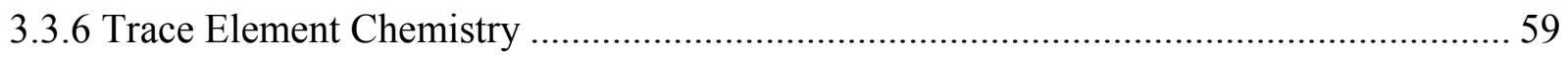

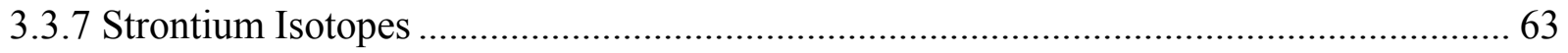

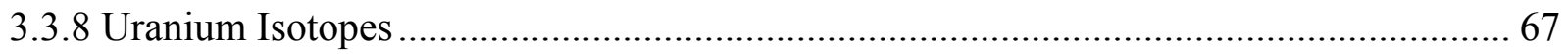

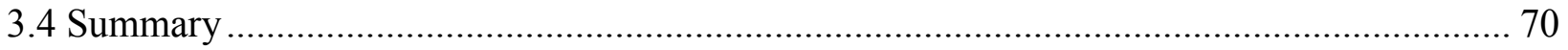


Chapter 4: Geochemical Evaluation of Sources, Flowpaths, and Travel Times of Groundwater Flow to Oasis Valley, Nevada ......................................................................... 73

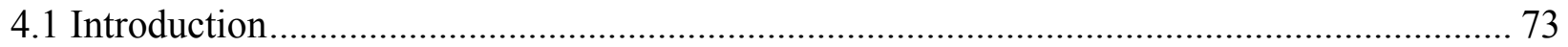

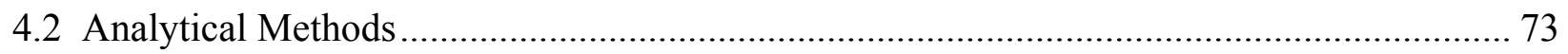

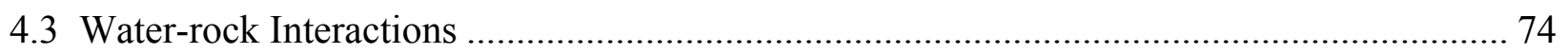

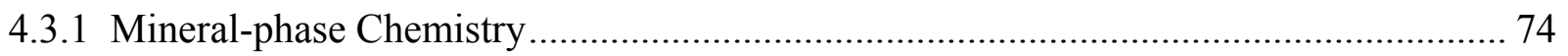

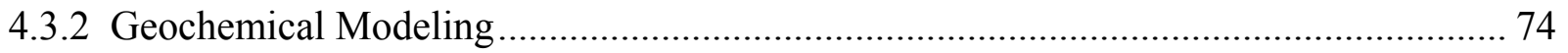

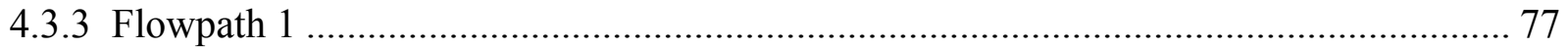

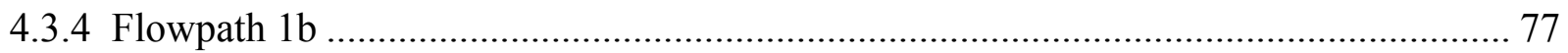

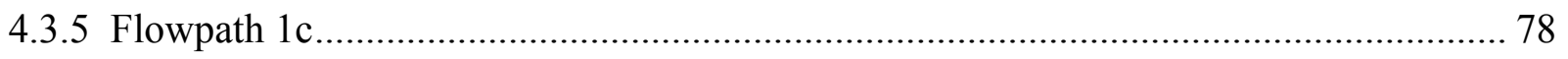

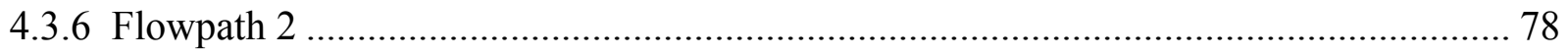

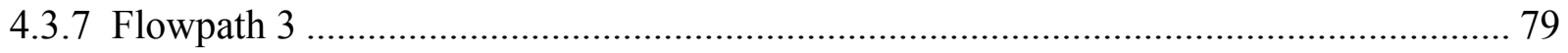

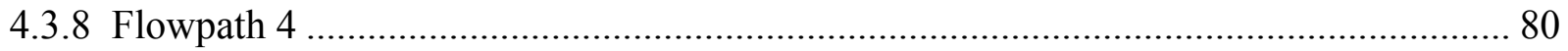

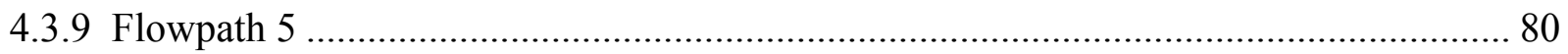

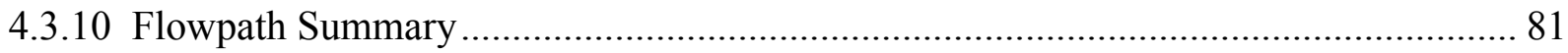

4.3.11 Limitations of the Geochemical Models................................................................. 81

4.4 Groundwater Travel-time Estimates .......................................................................... 82

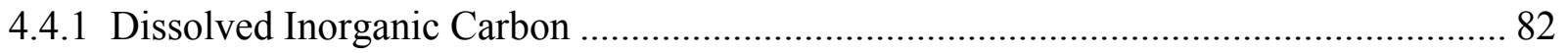

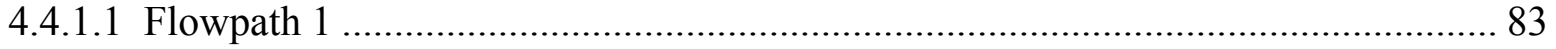

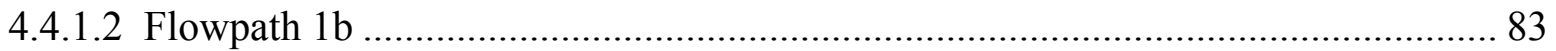

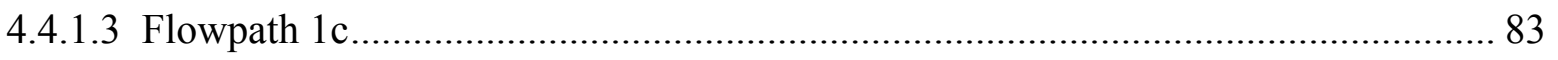

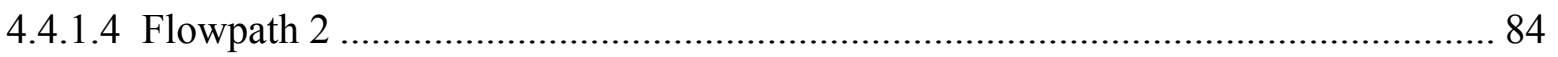

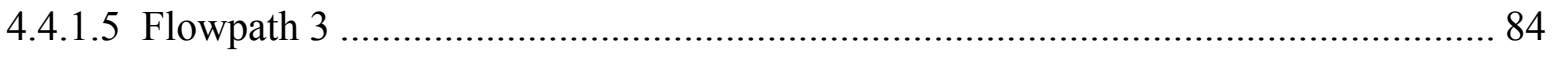

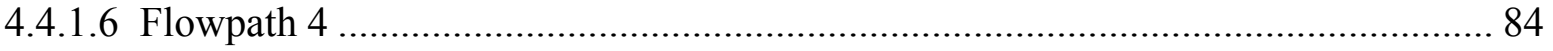

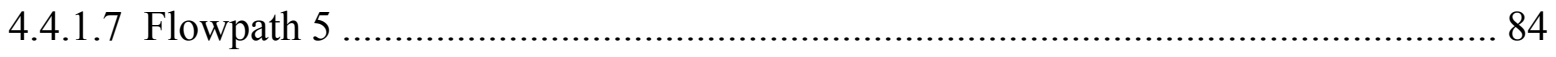

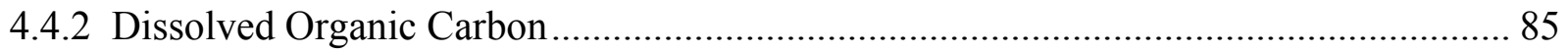

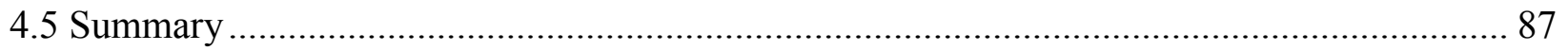

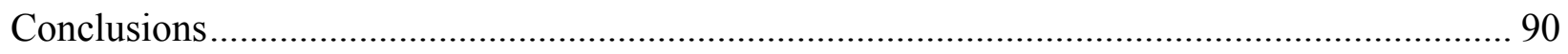

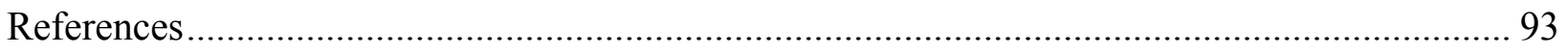

Appendices

A: Well completion data and spring discharge area lithologies for the PM-OV area.

B: Oasis Valley geochemistry sample location data and analytical results.

$\mathrm{C}$ : Oasis Valley geochemistry reference information. 


\section{List of Oversized Figures Located in the Back of the Report}

1-1. Pahute Mesa-Oasis Valley groundwater flow system.

1-8. Major-ion chemistry displayed by Stiff diagrams for wells and springs in the Oasis Valley flow system.

2-1. Map of precipitation sampling locations for the Oasis Valley flow system.

3-2. $\delta \mathrm{D}$ and $\delta^{18} \mathrm{O}$ values for wells and springs in the Oasis Valley flow system.

\section{List of Figures}

1-2. Nested east-west schematic cross sections of the NTS and adjacent areas..................... 4

1-3. Southwest-northeast schematic cross section from Pahute Mesa to the Amargosa

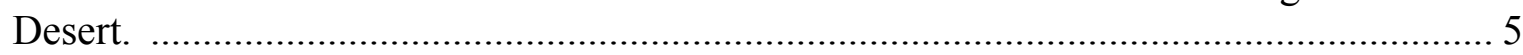

1-4. Water quality types in the Oasis Valley flow system. ............................................ 7

1-5. Major-ion chemistry of groundwater at Pahute Mesa, Rainier Mesa, and Fortymile

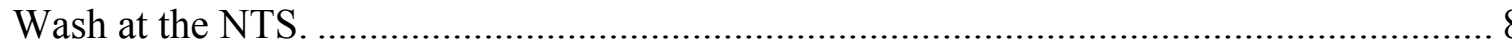

1-6. Major-ion chemistry of groundwater at the Kawich Range, Cactus Range, and Cactus Flat north of Oasis Valley and the NTS. ...................................................... 8

1-7. Major-ion chemistry of groundwater at Oasis Valley................................................ 9

1-9. Plot of $\delta^{18} \mathrm{O}$ versus $\delta^{13} \mathrm{C}$ values for Pahute Mesa calcite samples. .................................. 18

1-10. Plot of $\delta^{18} \mathrm{O}$ versus $\delta^{13} \mathrm{C}$ for calcite samples from Pahute Mesa and Yucca Mountain..... 19

1-11. Plot of $\delta^{18} \mathrm{O}$ versus sample depth for Pahute Mesa calcite samples ............................... 21

1-12. Same plot as shown in Figure 1-11, but with curves indicating the $\delta^{18} \mathrm{O}$ values of saturated zone calcites in equilibrium with $-15 \%$ groundwater along geothermal

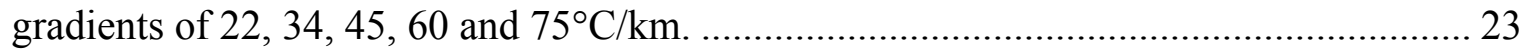

1-13. Plot of $\delta^{13} \mathrm{C}$ versus sample depth for Pahute Mesa calcite samples................................ 26

2-2. $\delta \mathrm{D}$ and $\delta^{18} \mathrm{O}$ of precipitation for the Oasis Valley flow system. .................................... 30

2-3. Mean $\delta \mathrm{D}$ weighted by precipitation amount vs. elevation for each precipitation sampling

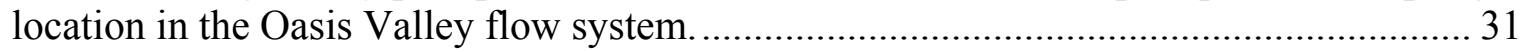

2-4. Mean $\delta^{18} \mathrm{O}$ weighted by precipitation amount vs. elevation for each precipitation sampling

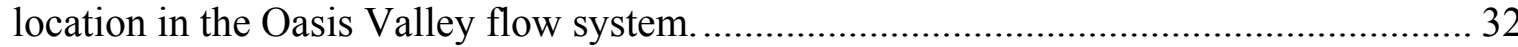

2-5. $\delta \mathrm{D}$ and $\delta^{18} \mathrm{O}$ of cool-season precipitation (October - June) in the Oasis Valley flow system.

2-6. $\delta \mathrm{D}$ and $\delta^{18} \mathrm{O}$ of warm-season precipitation (July - September) in the Oasis Valley flow system.

2-7. $\delta \mathrm{D}$ and $\delta^{18} \mathrm{O}$ of springs in the Kawich and Cactus ranges, Oasis Valley flow system. ..... 35

2-8. Major-ion chemistry of springs in the Kawich and Cactus ranges in the northern Oasis Valley flow system. 


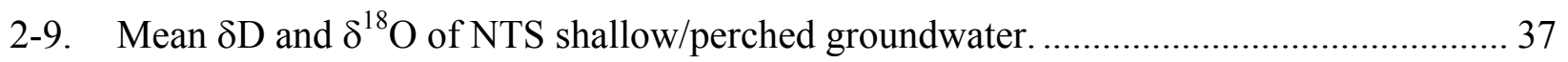

2-10. Major-ion chemistry of shallow/perched groundwater at the NTS................................... 38

2-11. $\delta \mathrm{D}$ and of precipitation and spring discharge in the Kawich and Cactus ranges.............. 39

2-12. $\delta \mathrm{D}$ and $\delta^{18} \mathrm{O}$ of precipitation and shallow/perched groundwater at the NTS. ................... 40

2-13. $\delta \mathrm{D}$ and $\delta^{18} \mathrm{O}$ of recent recharge and deep groundwater in the Oasis Valley flow system.

2-14. Major-ion chemistry or recent recharge, deep Pahute Mesa groundwater and central

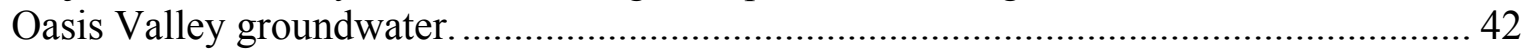

3-1. Location of groundwater sampling locations used in this investigation............................ 45

3-3. Comparison of $\delta \mathrm{D}$ and $\delta^{18} \mathrm{O}$ of groundwater in the Pahute Mesa-Oasis Valley region. ... 49

3-4. Carbon isotopic values of groundwater in the Pahute Mesa-Oasis Valley region.............. 51

3-5. Comparison of percent modern carbon and $\delta^{13} \mathrm{C}$ of groundwater in the Pahute Mesa-Oasis Valley region....................................................................................... 52

3-6. Tritium activity of groundwater in the Pahute Mesa-Oasis Valley region. ........................ 54

3-7. Helium isotopes of groundwater in the Pahute Mesa-Oasis Valley region. ........................ 55

3-8. Comparison of helium isotopes and helium concentrations in groundwater in the

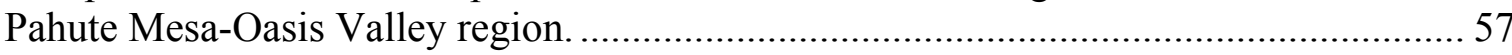

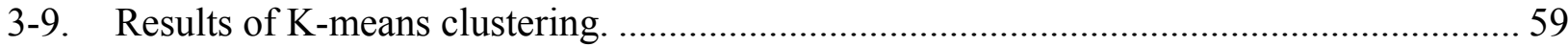

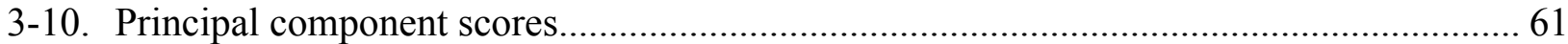

3-11. Spatial interpolation and population partitioning results for $\mathrm{PC} 1$ scores.............................. 62

3-12. Comparison of calcium and strontium concentrations in groundwater in the

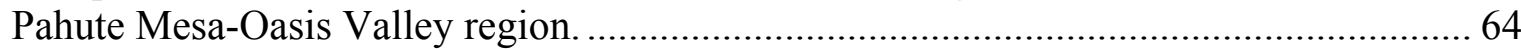

3-13. Strontium isotopic values of groundwater in the Pahute Mesa-Oasis Valley region.......... 65

3-14. Uranium concentrations in groundwater in the Pahute Mesa-Oasis Valley region. ........... 68

3-15. Comparison of sodium and uranium concentrations in groundwater in the

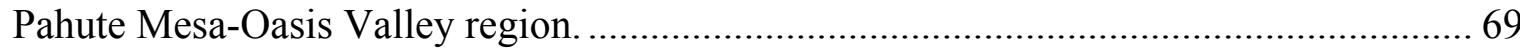

3-16. Uranium activity ratios in groundwater in the Pahute Mesa-Oasis Valley region.............. 70

3-17. Comparison of uranium concentrations and activity ratios in groundwater in the Pahute Mesa-Oasis Valley region. 


\section{List of Tables Located in the Back of the Report}

1-1. Hydrogeologic framework for the Pahute Mesa area.

4-1. Geochemical mass balance models for proposed flowpaths.

\section{List of Tables}

1-2. Summary of fracture-coating phase distribution as a function of hydrostratigraphy........ 12

1-3. Summary of micrographic and isotopic analyses of fracture-coating phases.................. 14

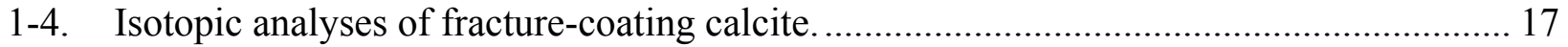

2-1. Precipitation sampling location, collection dates, and number of samples for each location for the Oasis Valley flow system. ............................................................. 29

2-2. Ranges, means, and standard deviation of precipitation $\delta^{18} \mathrm{O}$ and $\delta \mathrm{D}$ for each geographic recharge area for the Oasis Valley flow system. 30

2-3. Isotopic means weighted by precipitation amount for each sampling location for the Oasis Valley flow system............................................................................. 31

2-4. Major-ion chemistry of precipitation collected at the NTS. ......................................... 34

2-5. $\delta \mathrm{D}$ and $\delta^{18} \mathrm{O}$ of springs in the Kawich and Cactus ranges, Oasis Valley flow system..... 35

2-6. $\quad \delta \mathrm{D}$ and $\delta^{18} \mathrm{O}$ of Topopah and Whiterock springs, Raniner Mesa Tunnels U12n.03 and U12n.05, and wells UE-29a\#1 and UE-29a\#2 _......................................................... 37

4-2. Results of thermodynamic speciation calculations from NETPATH............................ 76

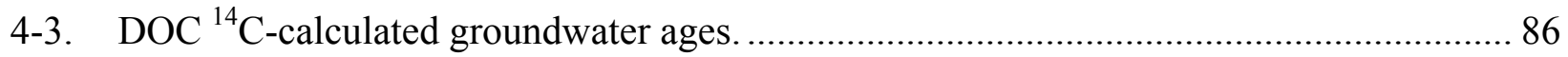

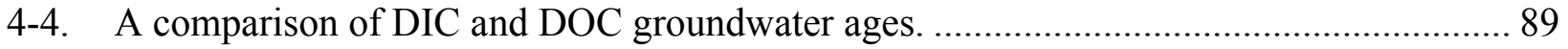




\section{Acronyms}

BSE backscattered electron

bgs below ground surface

CAU Corrective Action Unit

CFC chlorofluorocarbon

DIC dissolved inorganic carbon

DOC dissolved organic carbon

DOE U.S. Department of Energy

DRI Desert Research Institute

EDS energy dispersive spectroscopy

FFACO Federal Facility Agreement and Consent Order

GMWL global meteoric water line

HRTEM high-resolution transmission electron microscope

HSU hydrostratigraphic unit

ICP-MS inductively coupled plasma mass sprectrometer

$\mathrm{Kg} \quad$ kilogram

LLNL Lawrence Livermore National Laboratory

NAFR Nellis Air Force Range

NTS Nevada Test Site

PCA principal components analysis

$\mathrm{pCi} / \mathrm{L} \quad$ picoCuries per liter

PDB Pee Dee Belemnite

PM Pahute Mesa

pmc percent modern carbon

REE rare earth element

SEM scanning electron microscope

SMOW standard mean ocean water

TDS total dissolved solids

TU tritium unit

UGTA Underground Test Area

USGS U.S. Geological Survey

WDS wavelength dispersive spectroscopy 


\section{INTRODUCTION}

The Pahute Mesa-Oasis Valley flow system is of particular importance because of the potential movement of radionuclides through the system from the Nevada Test Site (NTS), principally from the Pahute Mesa underground nuclear testing area, to springs and wells in Oasis Valley (Figure 1-1 oversized; see back of report). Groundwater flow between Pahute Mesa and Oasis Valley is of concern because of the short travel distance to off-site water users. Groundwater flow and transport modeling simulations (DOE, 1997) show rapid tritium transport in the fractured volcanic rock aquifers along potential flowpaths in this region. These rapid transport estimates were based on limited water level and hydraulic conductivity data, estimates of groundwater recharge on Pahute Mesa and groundwater discharge rates in Oasis Valley, assumed porosities, and estimated retardation rates. Many of these parameters are constrained by limited data and may vary considerably within the area of interest. Geochemical investigations of the Oasis Valley flow system are focused on developing an environmental chemical and isotopic methodology that can be used to independently verify numerical groundwater flow modeling efforts (DOE, 1997).

This geochemical evaluation of the Pahute Mesa-Oasis Valley groundwater system fulfills several needs for the Underground Test Area (UGTA) project of the U.S. Department of Energy (DOE), National Nuclear Security Administration. The data set compiled for this task serves as a repository for groundwater geochemical data pertaining to the Western Pahute Mesa Corrective Action Unit (CAU). This evaluation also provides a baseline interpretation of the groundwater geochemistry for this region that will support verification of the UGTA regional hydrologic flow and transport model (DOE, 1997). Geochemical characterizations are vital to our understanding of the fate and transport of contaminants in the subsurface environment. The data described in this report were assembled by a consortium of geochemists including individuals from the Desert Research Institute (DRI), HSI-Geotrans, Lawrence Livermore National Laboratory (LLNL), the U.S. Geological Survey (USGS), and the Harry Reid Center for Environmental Studies at the University of Nevada, Las Vegas. The types of analyses include major-ion and trace element chemistry, stable isotopes of hydrogen, oxygen and carbon, carbon-14, tritium, dissolved noble gases, chlorofluorocarbons, strontium isotopes and uranium isotopes. As such, it represents a comprehensive evaluation of the groundwater geochemical characteristics of this flow system

This report is presented as four chapters. Chapter one introduces the hydrogeologic framework of the Pahute Mesa-Oasis Valley flow system and the effects of fracture-coating mineralogical phases on groundwater chemistry. Chapter two presents the chemical and isotopic compositions of groundwater recharge to the Pahute Mesa-Oasis Valley flow system. The recharge end members needed for geochemical modeling in later chapters are defined in this chapter. Chapter three presents new water chemistry and isotopic data collected for this study and geochemical and isotopic interpretations of groundwater flow in the Pahute Mesa-Oasis Valley flow system using both new and historical geochemical data. Chapter four presents geochemical modeling of the flowpaths delineated in chapter three to determine if the proposed flowpaths and mixing of groundwater from different sources are geochemically valid. In this chapter, travel times of groundwater to the Oasis Valley discharge area are calculated using the geochemical models developed for the major-ion chemistry. 


\section{CHAPTER 1 \\ HYDROGEOLOGIC FRAMEWORK OF THE PAHUTE MESA - OASIS VALLEY FLOW SYSTEM: EFFECTS OF FRACTURE-COATING MINERAL PHASES ON GROUNDWATER COMPOSITION}

\subsection{Introduction}

The viability of potential groundwater flowpaths in the Pahute Mesa-Oasis Valley flow system can be evaluated by using geochemical reaction path models to simulate the interaction between known aquifer mineralogy and the water compositions at different points along the flowpath. Considering that fracture flow is the predominant mechanism for groundwater and solute flow in the volcanic aquifers typical in the area, fracture-coating phases are likely to exert a significant influence on the composition of through-going water. Groundwater age constraints are provided by radiocarbon $\left({ }^{14} \mathrm{C}\right)$ measurements of dissolved inorganic carbon. One drawback to the ${ }^{14} \mathrm{C}$ dating method is that dissolved inorganic carbon can react with minerals in the aquifer, thereby modifying the ${ }^{14} \mathrm{C}$ age recorded by the groundwater. Calcite veins and fracture fillings in the volcanic aquifers on Pahute Mesa represent one potential source of exchangeable carbon (via equilibrium dissolution/precipitation). It is therefore of interest to examine the occurrence and isotopic composition of secondary calcite from Pahute Mesa to provide constraints for groundwater modeling efforts.

\subsection{Geology/Hydrostratigraphy}

Groundwater flow in this area occurs predominantly within Tertiary volcanic rocks of the southwest Nevada volcanic field (Christiansen et al., 1977). The Pahute Mesa - Oasis Valley region is largely comprised of silicic rock units from the Black Mountain caldera, Silent Canyon caldera complex, and Timber Mountain - Oasis Valley caldera complex (Byers et al., 1989). The area exhibits the effects of complex compound structural deformation as a result of caldera formation, extensional basin and range style tectonism, and through-going strike-slip faulting and extension related to the Walker Lane (Ferguson et al., 1994; Warren, 1994; Carr, 1990, Cummings, 1968). This complex geologic history has made the definition and evaluation of regionally significant hydrostratigraphic intervals and groundwater flowpaths both challenging and problematic.

Blankennagel and Weir (1973) established the general hydrogeologic foundation for the Pahute Mesa area that has provided the basis for much of the hydrogeologic work done in the area since. The available data have been integrated (Drellack and Prothro, written communication, Bechtel Nevada, 1997; Laczniak et al., 1996) into a hydrogeologic framework (summarized in Table 1-1. Hydrogeologic framework for the Pahute Mesa area (simplified after Drellack and Prothro, written communication, Bechtel Nevada, 1997), located in back of this report) for the Pahute Mesa area.

Here, the principal aquifer units have been identified as intracaldera lava flows of the Deadhorse Flat Formation and Calico Hills Formation. Extracaldera welded tuffs of the Paintbrush Group are significant aquifer units in western Pahute Mesa (Laczniak et al., 1996) and may serve as conduits for a significant amount of groundwater flow to the west.

Groundwater discharge in the Oasis Valley area occurs largely from extracaldera welded tuffs of the younger Timber Mountain Group and from alluvial deposits overlying these rocks. The relatively abundant data from within the Silent Canyon caldera complex on central Pahute Mesa demonstrate that the distribution of intracaldera volcanic aquifers is strongly influenced by the caldera boundaries (Laczniak et al., 1996). Water levels measured on Pahute Mesa (O'Hagan 
and Laczniak, 1996) indicate a (local) upward vertical flow gradient near the western margin of the Silent Canyon caldera complex and suggest that groundwater flow is similarly influenced by caldera boundaries. While there is limited hydrogeologic data between Pahute Mesa and Oasis Valley, there must be significant, structurally controlled movement of water into younger hydrostratigraphy as groundwater flows toward Oasis Valley. This is consistent with the presence of complex flowpaths, and is illustrated schematically in Figures 1-2 and 1-3.

The majority of the groundwater mass contained within these rocks is thought to be relatively isolated within the pores of the geologic media (Laczniak et al., 1996). Evidence indicates that groundwater movement in the southwest Nevada volcanic field is strongly influenced by the development of secondary permeability. Secondary permeability is enhanced in some cases by fracturing (e.g., the development of cooling joints and fractures in competent welded tuffs and lava flows) and alternatively reduced in other circumstances by the formation of alteration products (e.g., the zeolitization of bedded tuffs). While the mass of groundwater flowing through the system is thought to be relatively small compared to the total water mass contained within the volcanic pile, this flow is interpreted to occur relatively rapidly and take place along prominent interconnected fractures (Prothro and Drellack, 1997; Blankenagel and Weir, 1973). In such a "dual-porosity" system, essentially all significant groundwater movement takes place within these fractured transmissive hydrostratigraphic units that are the most likely conduits for transporting water and radionuclides the greatest distances (Reimus et al., 1998).

The use of numerical groundwater flow models (DOE, 1997) to simulate groundwater flow and solute transport requires comprehensive hydrogeologic models based on available hydrogeologic and geologic data. While the debate concerning geologic models of the Pahute Mesa area continues to evolve with the acquisition of new data, existing models (Warren, 1994; Grauch et al., 1997) clearly demonstrate that the volcanic units that serve as aquifers in the Pahute Mesa area have been strongly influenced by events that took place during and after the multiple episodes of caldera formation. The presence of significant faulting and fracturing and (at least) localized hydrothermal alteration products suggests that water quality as well as water flow is likely to be effected by the complex geologic history of the area.

\subsection{Groundwater Flow}

Groundwater flow in the Pahute Mesa - Oasis Valley area is part of the regional Death Valley Groundwater Basin (Harrill et al., 1988). The Death Valley Groundwater Basin covers an area of approximately $41,100 \mathrm{~km}^{2}\left(15,800 \mathrm{mi}^{2}\right)$ and includes principal recharge areas in the Spring Mountains and Sheep Range, and groundwater discharge areas in Ash Meadows, Oasis Valley, Alkali Flat and Death Valley. Local recharge areas have also been identified at Pahute Mesa, Rainier Mesa, Cactus Range, Fortymile Canyon, and Kawich Range (Winograd and Thordarson, 1975; Harrill et al., 1988; Laczniak et al., 1996; DOE, 1997).

The regional groundwater flow gradient (Figure 1-1) is generally from north to south. On a smaller scale, groundwater elevations in composite or multiple-completion wells exhibit significant variability (Blankennagel and Weir, 1973; Laczniak et al., 1996; O’Hagan and Laczniak, 1996). Groundwater flow interpretations (Blankennagel and Weir, 1973; White and Chuma, 1987) are affected by the complex geology and also by data gaps within the Pahute Mesa - Oasis Valley area. The delineation of the northeastern boundary of the Pahute Mesa Oasis Valley flow system is an important component in identifying which, if any, test localities on Pahute Mesa could potentially contribute contaminants to groundwater ultimately discharging in Oasis Valley (Laczniak et al., 1996). 


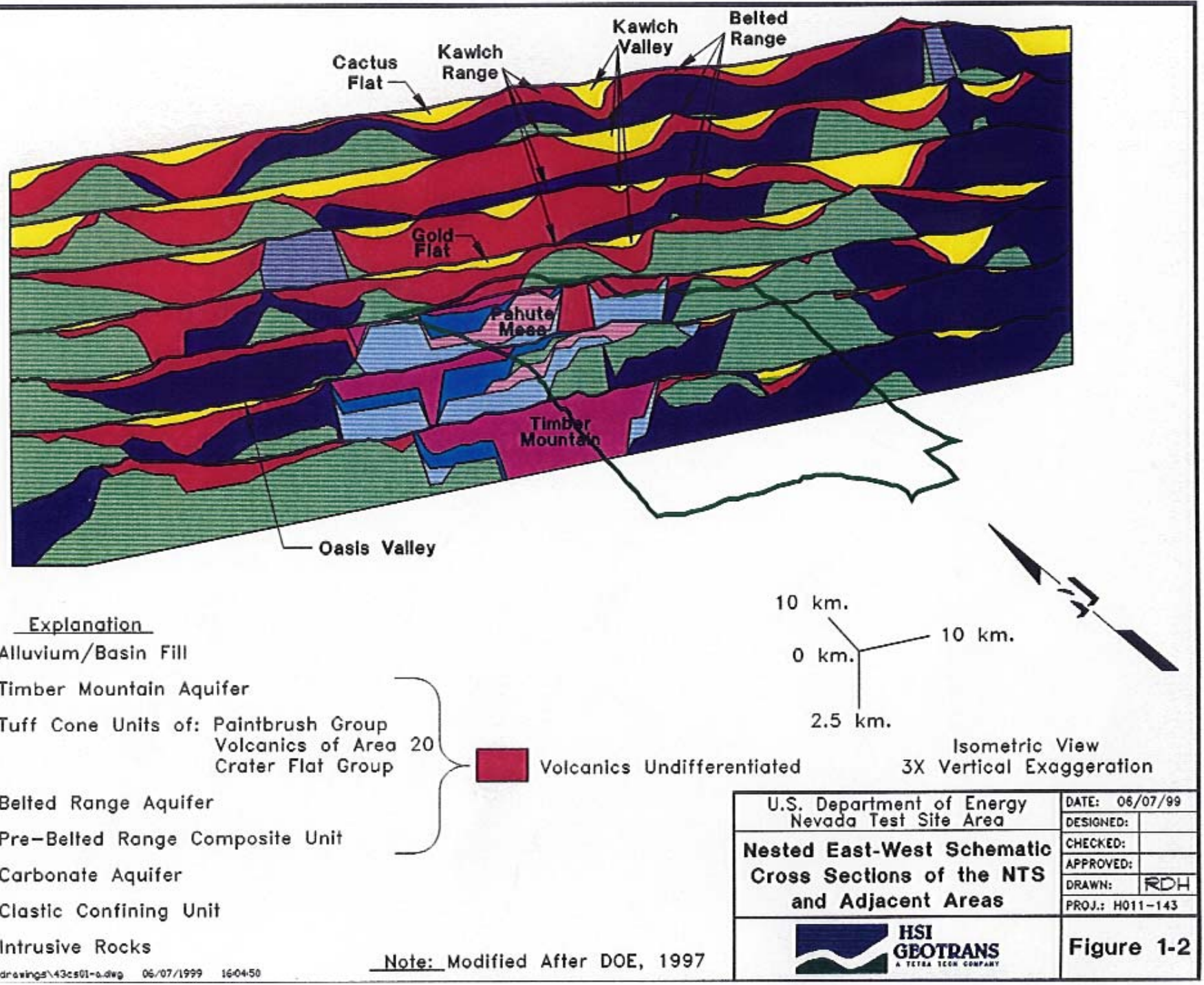

Figure 1-2. Nested east-west schematic cross sections of the NTS and adjacent areas. 


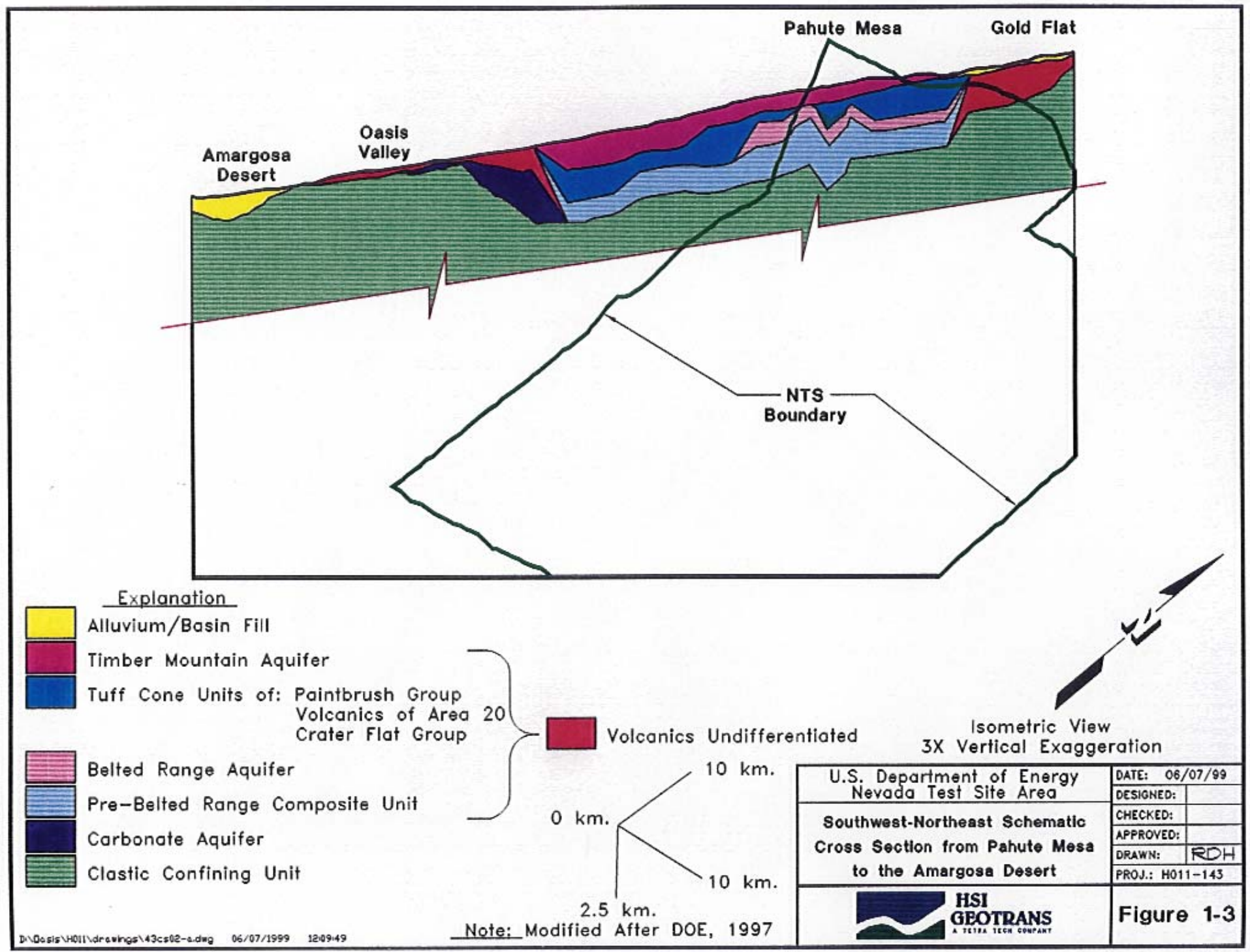

Figure 1-3. Southwest-northeast schematic cross section from Pahute Mesa to the Amargosa Desert. 


\subsection{Water Balance}

The most recent summary of water balance data for the Pahute Mesa - Oasis Valley flow system (Laczniak et al., 1996) relies heavily on estimates originally calculated by Blankennagel and Weir (1973). Potential recharge on Pahute Mesa and Rainier Mesa is estimated to be 3,150 acre-ft/yr (Blankennagel and Weir, 1973). The regional groundwater flow model constructed for the NTS (DOE, 1997) incorporates recharge estimates that are approximately 25 to 30 percent lower. Subsurface inflow to Pahute Mesa from the north (Kawich Valley and Gold Flat) is estimated to be 5,500 acre-ft/yr (Blankennagel and Weir, 1973). Groundwater flux leaving the area across the southern margins of the Rainier Mesa/Pahute Mesa areas has been estimated at $8,000 \mathrm{acre}-\mathrm{ft} / \mathrm{yr}$ (Blankennagel and Weir, 1973). This volume of water leaves along the entire southern and southwestern margins of the area and is distributed to outflow toward Crater Flat, Jackass Flats, and the Amargosa Valley as well as toward Oasis Valley. The relative volume of this flow directed toward Oasis Valley is undefined. Estimates of groundwater discharge and evapotranspiration losses in Oasis Valley range from 2,000 to 7,700 acre-ft/yr (DOE, 1997). The lower end of this range represents an older estimate (Malmberg and Eakin, 1962) and upper value is a more recent estimate calculated by Reiner et al. (2002). If the higher values of estimated Oasis Valley discharge volumes are accurate, this apparently "excess" water would have to come from Pahute Mesa (suggesting either an underestimate of local recharge or groundwater inflow to Pahute Mesa from the north) or a significant groundwater flow contribution from an alternate source to the north.

\subsection{Major-ion Water Chemistry}

The dissolved constituents in groundwater provide a record of the minerals encountered as water moves through an aquifer. Thus, water chemistry can be used to trace the movement of groundwater. Schoff and Moore (1964), Blankennagel and Weir (1973), and Winograd and Thordarson (1975) identified three hydrochemical facies in and near the NTS. These included an $\mathrm{Na}-\mathrm{K}-\mathrm{HCO}_{3}$ facies from groundwater in volcanic rocks. Chapman and Lyles (1993) compiled water chemistry data from the NTS analyzed by the U.S. Geological Survey (USGS) and Desert Research Institute (DRI) from 1957 through 1990. They compared both temporal analyses from the same sampling location and the areal distribution of different water types based on host lithology. They affirmed the occurrence of the $\mathrm{Na}-\mathrm{K}-\mathrm{HCO}_{3}$ volcanic facies but noted a transition in chemical composition of volcanic water at Pahute Mesa. The groundwater in the eastern side of Pahute Mesa contained a higher proportion of $\mathrm{Ca}$ and $\mathrm{Mg}$ than other volcanic waters (coincident with a downward vertical hydraulic gradient) while the western side of Pahute Mesa contained a higher proportion of $\mathrm{Cl}$ and $\mathrm{SO}_{4}$ (coincident with an upward vertical flow gradient), suggested to result from interaction with hydrothermally altered zones (also see Blankennagel and Weir, 1973).

To trace the movement of groundwater in the Oasis Valley area, samples from 10 wells and four springs were collected during November 1997. Additionally, two wells at Pahute Mesa, two wells in Fortymile Wash, and one well at Tolicha Peak were sampled. Samples were collected in clean high-density polyethylene bottles that were triple rinsed with sample groundwater prior to filling. All samples were filtered with a 0.45-: m cartridge filter and cation samples were preserved with nitric acid $\left(\mathrm{HNO}_{3}\right)$. Samples were analyzed at DRI's Division of Hydrologic Sciences Analytical Chemistry Laboratory in Reno, Nevada. Historical groundwater chemical data were also incorporated to complete the data set. These included groundwater sampling locations with complete major-ion and deuterium $(* \mathrm{D})$ and/or oxygen-18 $\left({ }^{* 18} \mathrm{O}\right)$ analyses from 
13 wells and five Area 12 Tunnel seeps at the NTS and six wells and 14 springs at the Tonopah Test Range. For sample locations with multiple analyses spanning several years or more, one analysis was selected to represent the water quality of that location. The sample locations are shown on Figure 1-1. Well and spring locations, and well completion information for wells and springs used in this evaluation, are included in Appendix A. Chemical data are listed in Appendix B-1 (data for samples collected during November 1997) and Appendix B-2 (historical data).

Water quality in the study area can be categorized into four main types as shown in Figure 1-4. The sodium bicarbonate $\left(\mathrm{Na}-\mathrm{HCO}_{3}\right)$ type has greater than 50 percent sodium as the principal cation and greater than 50 percent bicarbonate as the principal anion. The calcium-bicarbonate $\left(\mathrm{Ca}-\mathrm{HCO}_{3}\right)$ type is greater than 50 percent calcium and 50 percent bicarbonate. The sodium bicarbonate/sulfate mixture $\left(\mathrm{Na}-\mathrm{HCO}_{3} / \mathrm{SO}_{4}\right)$ and calcium bicarbonate/sulfate mixture $\left(\mathrm{Ca}-\mathrm{HCO}_{3} / \mathrm{SO}_{4}\right)$ have either greater than 50 percent sodium or calcium cations and a relatively even mix of bicarbonate and sulfate anions.

The Na- $\mathrm{HCO}_{3}$ type occurs predominantly in the NTS areas of Pahute Mesa, Rainier Mesa, and Fortymile Wash and is most likely the result of dissolution of volcanic rhyolitic lava, ash-fall and ash-flow tuffs, and associated volcanic alluvium (Figure 1-5). Two locations at the NTS, Pahute Mesa \#3 and U12n Tunnel, have elevated levels of sulfate and fall within the $\mathrm{Na}-\mathrm{HCO}_{3} / \mathrm{SO}_{4}$ type. The $\mathrm{Ca}-\mathrm{HCO}_{3}$ type is only found in the perched springs of the Kawich and Cactus ranges north of Oasis Valley and the NTS (Figure 1-6). This water type most likely results from dissolution of limestone and dolomite and carbonate found among the quartzite, shale, siltstone, and sandstone exposed in the Kawich and Cactus ranges. The Paleozoic clastic and carbonate rocks occur as relatively minor outcrops in the predominantly volcanic rock ranges. Interestingly, the wells located in the Cactus Flat alluvial aquifer are of the $\mathrm{Na}-\mathrm{HCO}_{3}$ type, showing the predominance of volcanic-derived alluvium in the valley. The $\mathrm{Ca}-\mathrm{HCO}_{3} / \mathrm{SO}_{4}$ mixed type is not widespread and is found in only three springs, one in the Cactus Range and

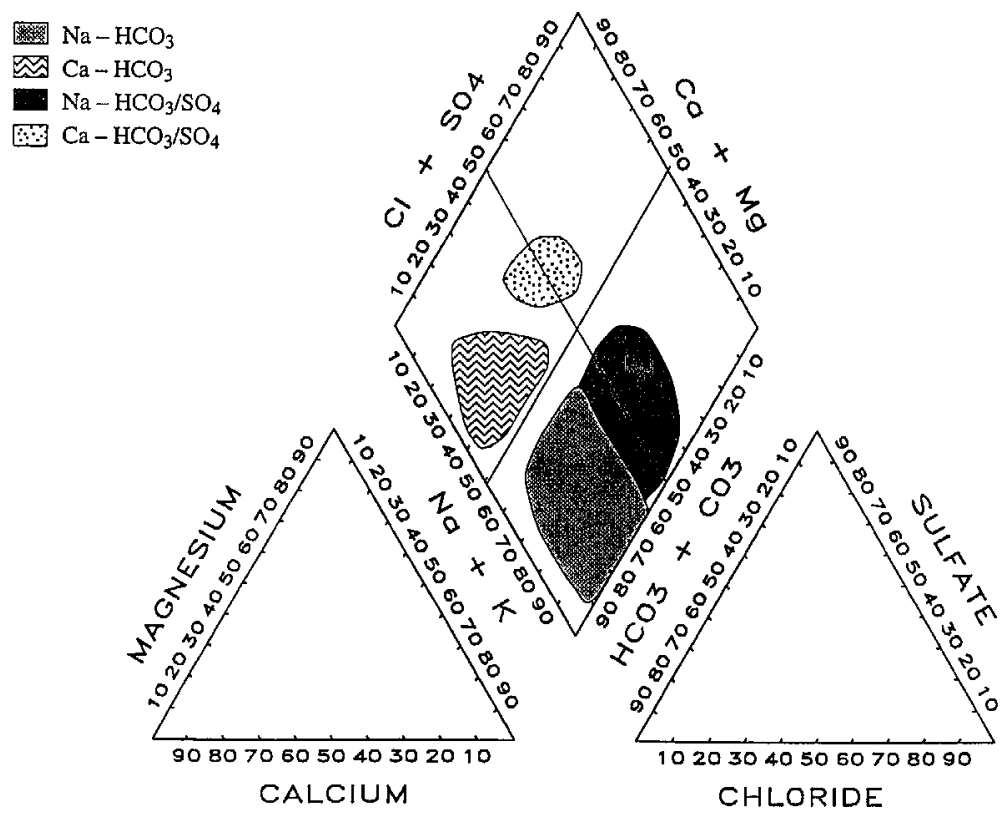

Figure 1-4. Water quality types in the Oasis Valley flow system. 


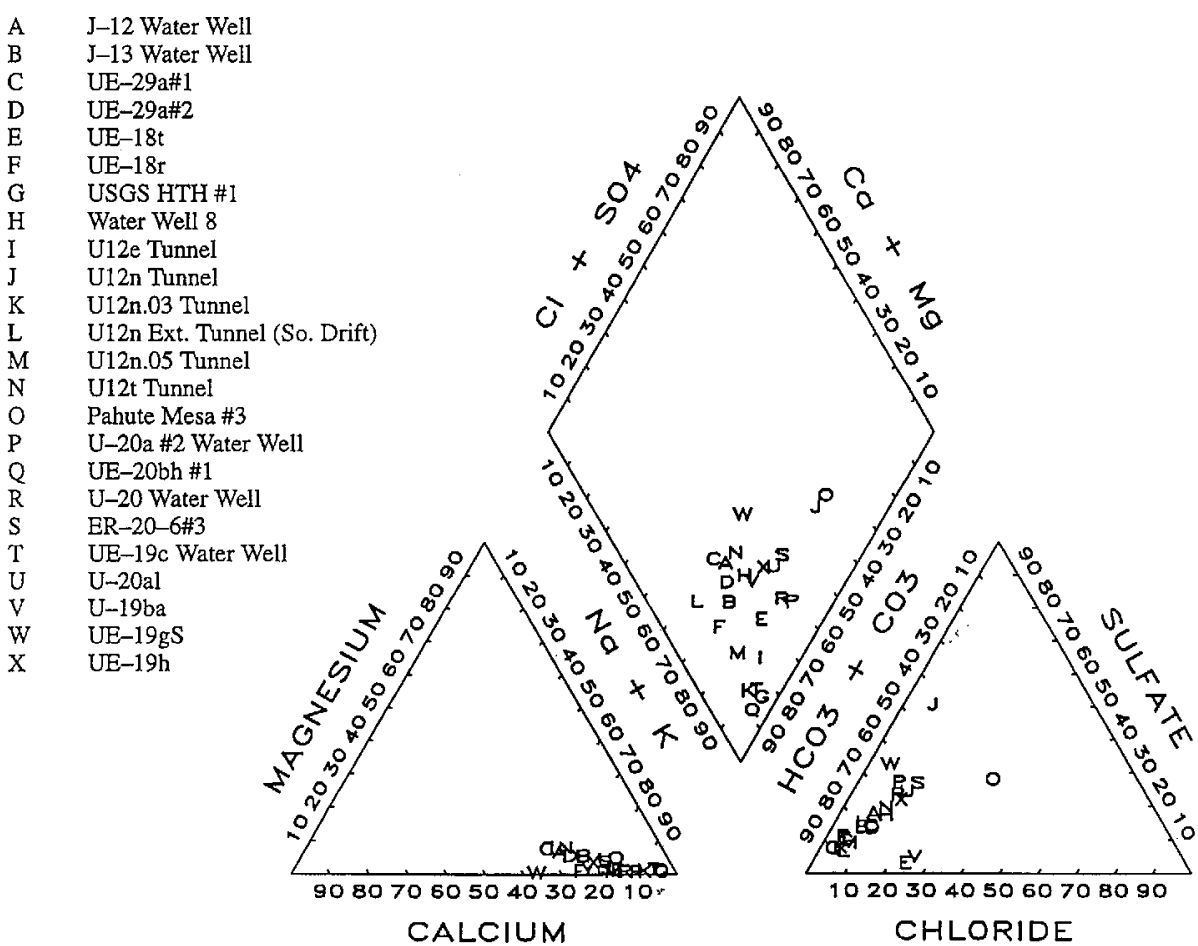

Figure 1-5. Major-ion chemistry of groundwater at Pahute Mesa, Rainier Mesa, and Fortymile Wash at the NTS.

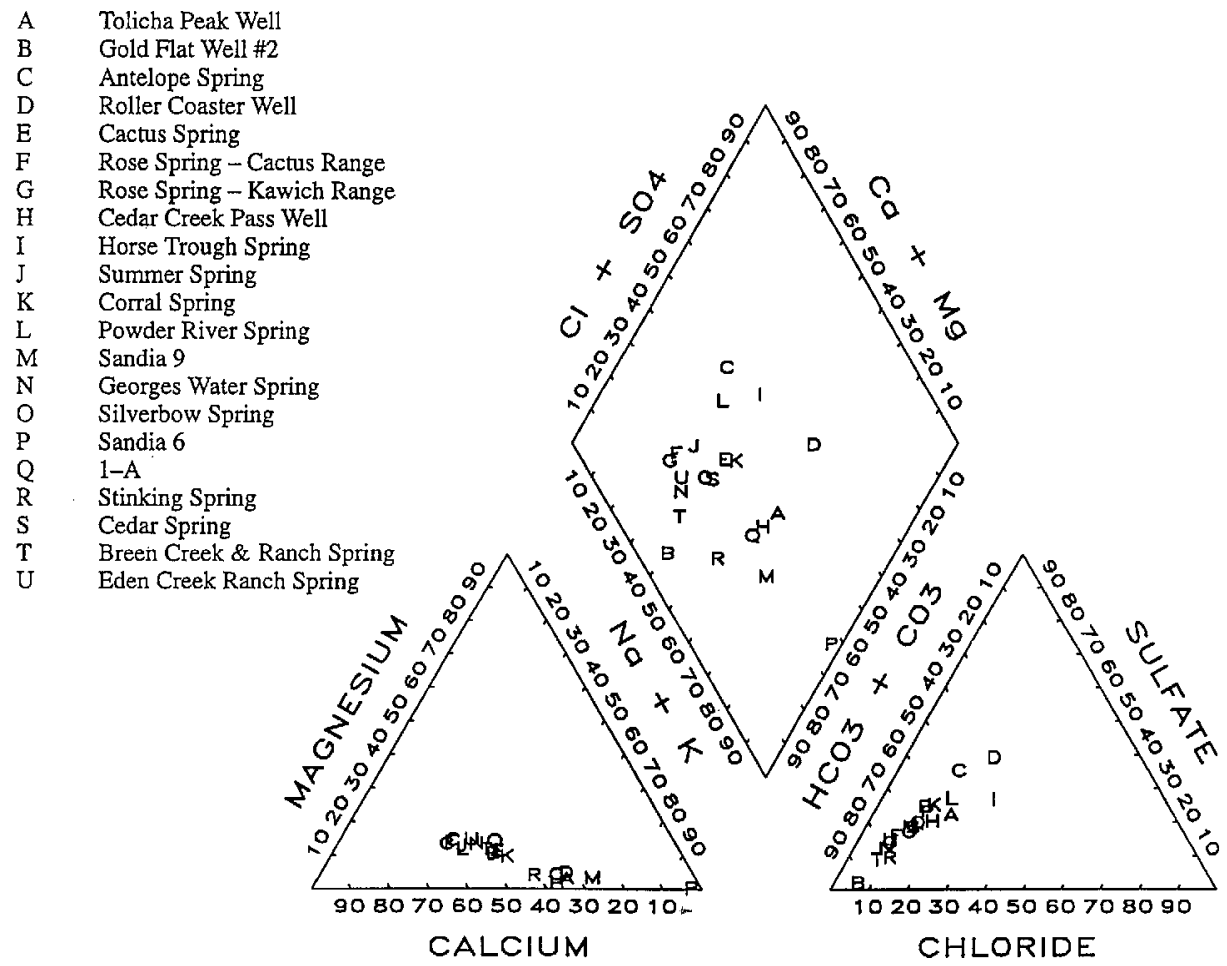

Figure 1-6. Major-ion chemistry of groundwater at the Kawich Range, Cactus Range, and Cactus Flat north of Oasis Valley and the NTS. 
two in the Kawich Range (Figure 1-6). This type is most likely the result of dissolution of small amounts of gypsum found locally near these springs. The $\mathrm{Na}-\mathrm{HCO}_{3} / \mathrm{SO}_{4}$ type is found mainly in Oasis Valley proper (Figure 1-7) and in western Pahute Mesa. The increased concentrations of sulfate are attributed to the interaction with hydrothermal mineralization between Pahute Mesa and Oasis Valley and are supported by an elevated thermal gradient in western Pahute Mesa (Blankennagel and Weir, 1973), hot springs in Oasis Valley, and the presence of sulfide minerals in boreholes on western Pahute Mesa (Blankennagel and Weir, 1973; IT Corp., 1998).

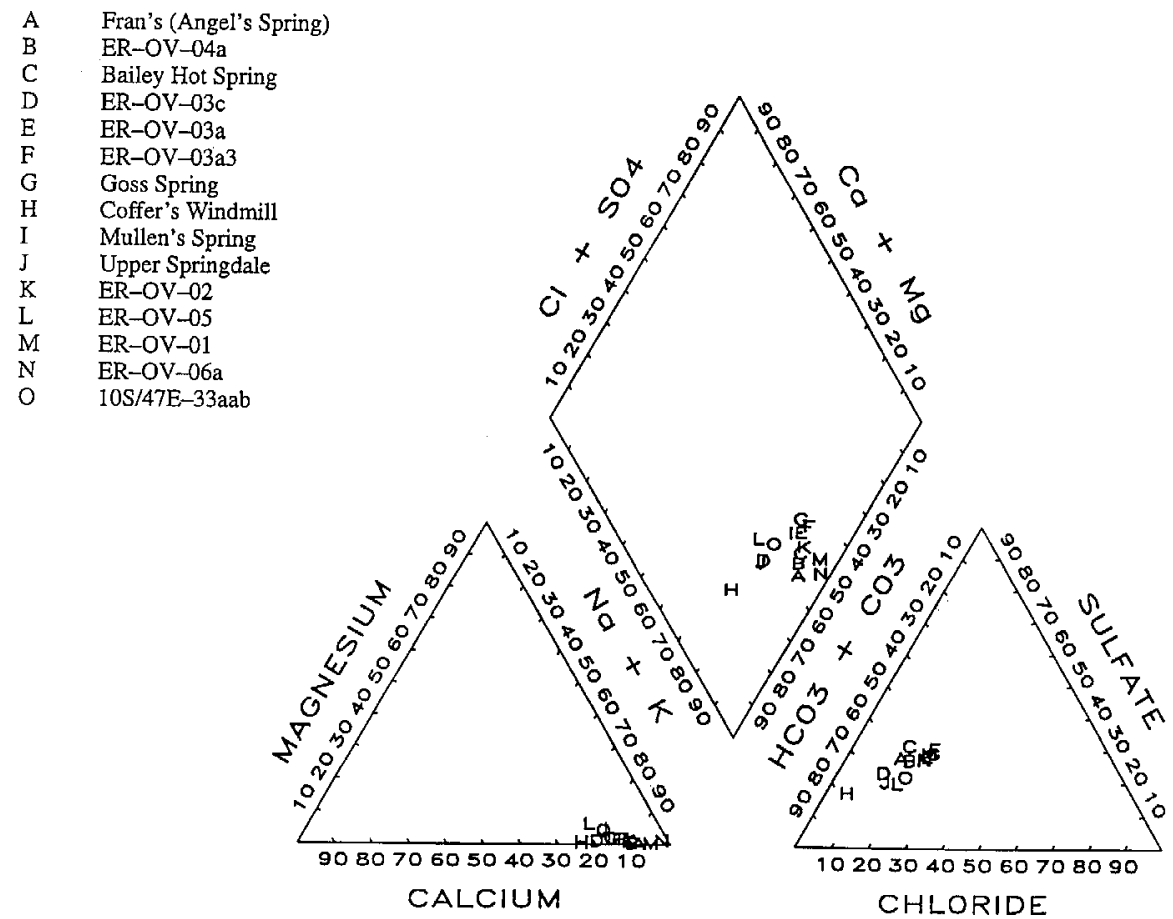

Figure 1-7. Major-ion chemistry of groundwater at Oasis Valley.

Spatial variations in water quality for the study area are presented in Figure 1-8 (Major-ion chemistry displayed by Stiff diagrams for wells and springs in the Oasis Valley flow system located in the back of this report). From the Stiff diagrams, preliminary flowpaths can be evaluated considering the possible geochemical evolution of groundwaters as they flow from one area to the next. In general, groundwater is thought to flow from north to south and from Pahute Mesa to Oasis Valley (Blankennagel and Weir, 1973; Laczniak et al., 1996; IT Corp., 1998). Lower total dissolved solids (TDS) groundwaters from Pahute Mesa may flow south toward Fortymile Wash and toward Oasis Valley. Groundwaters flowing southward toward Fortymile Wash react with volcanic rocks, increasing slightly in TDS and possibly mixing with low-TDS waters recharging in Fortymile Wash. A minimal increase in sulfate occurs. Pahute Mesa groundwaters flowing southwest toward Oasis Valley react with both volcanic rocks and hydrothermal minerals, increasing TDS, sodium and potassium, and sulfate concentrations. North of Oasis Valley, the high-TDS Ca- $\mathrm{HCO}_{3}$ waters of the Cactus and Kawich ranges, compared with the low-TDS Na- $\mathrm{HCO}_{3}$ waters of Cactus Flat, suggest that little of the perchedwaters is flowing southward or mixing with waters in Cactus Flat. Although sample locations are sparse and wells are completed in alluvium, geochemically, the dilute low-TDS 
waters of Cactus Flat and Gold Flat could flow southward, reacting with both volcanic rocks and hydrothermal minerals to produce the water quality observed in Oasis Valley.

\subsection{Flowpath Identification and Delineation}

Several potential flowpaths (identified on Figure 1-1) for groundwater movement in the Pahute Mesa - Oasis Valley area were selected to evaluate their geochemical viability. These include:

1) Groundwater from Pahute Mesa to Oasis Valley, with variants including:

- Groundwater from Pahute Mesa plus local recharge to Oasis Valley, and

- Groundwater from Pahute Mesa mixing with shallow groundwater in Oasis Valley;

2) Groundwater from Pahute Mesa mixing with a northern source and flowing to Oasis Valley;

3) Groundwater with a northern source flowing to northwestern Oasis Valley;

4) Groundwater from eastern Pahute Mesa flowing south around Timber Mountain and down Beatty Wash to Oasis Valley; and

5) Groundwater from eastern Pahute Mesa flowing toward Jackass Flats.

The evaluation of these flowpaths will be discussed in Chapter 4.

\subsection{Fracture-coating Phase Characterization}

As part of these geochemical investigations, fracture-coating mineral phases from drill samples from the Pahute Mesa area of the NTS were analyzed using micrographic and geochemical methods. Samples were selected based on the presence of natural fractures and on the types and abundance of secondary mineral phases present on those fracture surfaces. Mineral phases present along fracture surfaces are significant because, through the process of water-rock interaction, they can either contribute (as a result of dissolution) or remove (as a result of precipitation or adsorption) constituents from solution. Particular attention was paid to secondary calcite occurrences because they represent a potential source of exchangeable carbon and can interact with groundwater resulting in a modified isotopic signature and apparent water age. This section is a synthesis of pertinent data that are discussed in more detail elsewhere (IT Corp., 1998; Rose et al., 1999).

\subsubsection{Approach}

Sample properties that were selected for evaluation include:

$>$ Mineralogy of phases present on open fracture surfaces;

$>$ Chemical compositions of mineral phases that are assumed to be relatively soluble (e.g., volcanic glass or feldspars) or phases (such as zeolites or iron and manganese oxyhydroxides) that are assumed to be effective substrates for the adsorption of dissolved solutes; and,

$>$ Presence of calcite and the stable isotope $\left({ }^{13} \mathrm{C} /{ }^{12} \mathrm{C}\right.$ and $\left.{ }^{18} \mathrm{O} /{ }^{16} \mathrm{O}\right)$ and ${ }^{14} \mathrm{C}$ compositions of calcite. These data are important for evaluating calcite origins, and for assessing water-rock interaction processes that can influence the determination of groundwater ages. 


\subsubsection{Sample Descriptions}

Nineteen sub-samples were collected from drill core, cuttings, and percussion gun sidewall core archived at the USGS Core Library in Mercury, Nevada. A preference was given to core samples, due to the high quality preservation of mineral-phase relationships on fracture surfaces, but cuttings and percussion gun sidewall cores were also collected for the isotopic analysis of calcite based on information contained in Warren et al. (1998). The locations of the six drill holes (UE-18t, U-19ar, U-20as, UE-20f, PM-2, PM-3) that were sampled are shown in Figure 1-1.

Drill hole information including standing water level (from Laczniak et al., 1996), depth interval sampled, and lithostratigraphic (from drill logs on file at the USGS Core Library and from Warren et al., 1998) and hydrostratigraphic (from Prothro and Drellack, 1997) descriptions of sample intervals are summarized in Table 1-2. Additional data were derived from a report summarizing a fracture analysis conducted on Pahute Mesa (Drellack et al., 1997), which includes drill holes UE-18t and UE-20f. For a detailed description and discussion of calcite textures, coexisting vein minerals, and host rock lithologies, the reader is referred to IT Corp. (1998).

\subsubsection{Analytical Methods}

The micrographic analyses were performed using a combination of optical petrographic, scanning electron micrographic (SEM), electron microprobe, and high-resolution transmission electron micrographic techniques.

The SEM used is a JEOL 5800LV coupled with an Oxford ISIS EDS (energy dispersive spectroscopy) system. Typical accelerator voltage used on the SEM was $20 \mathrm{kV}$. Due to the size constraints of the SEM sample chamber, portions (up to $3 \mathrm{~cm} \times 3 \mathrm{~cm}$ ) of the natural exposed open fracture surfaces were separated from the main sample and gold-coated for textural and mineralogical evaluation in the SEM.

The electron microprobe is a JEOL 8900. Microprobe analyses were corrected using wavelength dispersive spectroscopy (WDS) and ZAF (atomic number - absorption fluorescence) oxide correction procedures. Backscattered electron (BSE) images and quantitative, large-scale digital x-ray images (or elemental maps) were collected using wavelength spectrometers by rastering the stage under a stationary electron probe.

The high-resolution transmission electron microscope (HRTEM) analyses were conducted under contract by the Transmission Electron Microscopy Laboratory, at the University of New Mexico in Albuquerque. Ion-milled thin sections and powder samples were prepared for four separate sub-samples. All HRTEM analyses were conducted using a JEOL 2010 HRTEM and associated Link ISIS EDS system with an ultra-thin window for the detector.

Calcite veins and fracture coatings were separated from the host rock using dental tools and picks. Calcite was ground in a mortar and pestle, sieved to $-100 /+150$ mesh size, washed in deionized water and acetone, and dried in a convection oven at $80^{\circ} \mathrm{C}$. In some samples, the calcite was dispersed as microcrystalline cement throughout the rock matrix. Under these circumstances, the entire sample was crushed, sieved and washed. Detailed analysis of selected layers of vein material typically involved the careful removal of calcite with a carbide dental bur mounted on a small rotary drill. Samples prepared in this manner were very fine grained, and were not washed prior to analysis. 
Table 1-2. Summary of fracture-coating phase distribution as a function of hydrostratigraphy (IT Corp., 1998).

\begin{tabular}{|c|c|c|c|}
\hline Hydrostratigraphic Unit & Saturated or Unsaturated & Characteristic Mineral Assemblage & Specific Examples \\
\hline Timber Mountain Aquifer & Unsaturated & $\begin{array}{l}\text { Calcite } \\
\text { Illite/smectite } \\
\text { Hydrated silica polymorph }\end{array}$ & $\begin{array}{l}\text { U-19ar (173') } \\
\text { PM-2 (320') }\end{array}$ \\
\hline Timber Mountain Aquifer & Saturated & $\begin{array}{l}\text { Calcite } \\
\text { Illite/smectite } \\
\text { K- and alkali feldspar } \\
\text { Zeolites } \\
\text { Quartz } \\
\text { Fe-oxyhydroxides }\end{array}$ & $\begin{array}{l}\text { UE-18t (1378') } \\
\text { UE-18t (1390.5') } \\
\text { UE-18t (1399') } \\
\text { UE-18t (2002') } \\
\text { UE-18t (2020') } \\
\text { UE-18t (2583') }\end{array}$ \\
\hline Upper Paintbrush Confining UNIT & Saturated & $\begin{array}{l}\text { Calcite } \\
\text { Smectite }\end{array}$ & PM-3 (1750') \\
\hline Belted Range Aquifer & Saturated & $\begin{array}{l}\text { Fe- and Mn-oxyhydroxides } \\
\text { Quartz } \\
\text { Calcite } \\
\text { K- and alkali feldspar } \\
\text { Illite/smectite }\end{array}$ & UE-20f (8668') \\
\hline Pre-Belted Range Composite Unit & Saturated & $\begin{array}{l}\text { Quartz } \\
\text { Carbonate minerals }(\mathrm{Ca}, \mathrm{Mg}, \mathrm{Fe}, \mathrm{Mn}) \\
\text { Sulfate minerals }(\mathrm{Ca}, \mathrm{Ba}, \mathrm{Sr}) \\
\text { Pyrite } \\
\text { Chlorite } \\
\text { Epidote } \\
\text { Illite/smectite } \\
\text { Fe-oxyhydroxides }\end{array}$ & $\begin{array}{l}\text { UE-20f }\left(13674^{\prime}\right) \\
\text { PM-2 }\left(4180^{\prime}\right) \\
\text { PM-2 }\left(5893^{\prime}\right) \\
\text { PM-2 }\left(6750^{\prime}\right) \\
\text { PM-2 }\left(8050^{\prime}\right) \\
\text { PM-2 }\left(8403^{\prime}\right)\end{array}$ \\
\hline
\end{tabular}


Isotopic analytical methods follow procedures outlined in the Standard Operating Procedures for the UGTA project, (LLNL, 1995). Calcite samples were reacted with $100 \%$ phosphoric acid at $25^{\circ} \mathrm{C}$ (McCrea, 1950) and the resulting $\mathrm{CO}_{2}$ gas was purified and split into aliquots for stable isotope and radiocarbon analysis. Carbon and oxygen stable isotope ratios were measured on a VG Prism mass spectrometer. Results are reported using the conventional $\delta$ notation relative to the Pee Dee Belemnite (PDB) (carbon) and standard mean ocean water (SMOW) (oxygen) standards (in per mil (\%o)). Isotope ratios were calibrated using the following National Bureau of Standards (NBS) calcite reference standards (Coplen et al., 1983; Reed, 1992):

$\begin{array}{ccc} & \delta^{13} \mathrm{C}(\% \text { PDB }) & \delta^{18} \mathrm{O}(\% \text { SMOW }) \\ \text { NBS-18 } & -5.04 & +7.16 \\ \text { NBS-19 } & +1.95 & +28.65 \\ \text { NBS-20 } & -1.06 & +26.64\end{array}$

Reproducibility on the reference standards was better than $\pm 0.1 \%$ for carbon and $\pm 0.15 \%$ for oxygen (Table 1-4). Duplicate preparation and analysis of five unknowns yielded similar reproducibility for most samples. Somewhat higher standard deviations on one $\delta^{13} \mathrm{C}$ and two $\delta^{18} \mathrm{O}$ replicates may reflect inhomogeneous sample compositions.

$\mathrm{CO}_{2}$ sample splits intended for ${ }^{14} \mathrm{C}$ analysis were reduced to graphite by reaction with hydrogen gas at $570^{\circ} \mathrm{C}$ in the presence of a cobalt metal catalyst and analyzed by accelerator mass spectrometry at LLNL (Vogel et al., 1987). Results are reported as percent modern carbon (pmc), which represents the ${ }^{14} \mathrm{C} /{ }^{12} \mathrm{C}$ ratio of the sample normalized to the ratio of 1950 atmospheric $\mathrm{CO}_{2}$ (Stuiver and Polach, 1977). Radiocarbon ages were calculated using a half-life of 5,568 years (Libby, 1955).

\subsubsection{Results of Micrographic Analyses}

The results of fracture-coating phase characterization activities are summarized in Table 1-3. Fourteen core samples with well-preserved fracture-coating phases were collected from three of the six drill holes selected for evaluation. Six other samples (cuttings and percussion gun sidewall cores) of nonfractured calcite-bearing materials were collected primarily for a carbon isotopic evaluation, which is summarized in section 1.5. Three of the principal volcanic aquifers present on Pahute Mesa are represented by the samples collected.

Eight samples representing the Timber Mountain Aquifer were collected from three different drill holes (UE-18t, U-19ar, PM-2). Two of these samples come from above the present-day water table (one being a nonfractured percussion gun sidewall core from U-19ar) and six samples come from below the present-day water table in a single drill hole (UE-18t). From these limited samples, fracture-coating phases within the Timber Mountain Aquifer system can be characterized by calcite + mixed illite/smectite + opaline silica in the unsaturated zone and by calcite + mixed illite/smectite + quartz + feldspars + zeolites + Fe- and Mnoxyhydroxides in the saturated zone. 
Table 1-3. Summary of micrographic and isotopic analyses of fracture-coating phases. Data are from IT Corp. (1998), ${ }^{(1)}$ Warren et al. $(1998),{ }^{(2)}$ or assumed for modeling purposes. ${ }^{(3),(4)}$ Data for $\mathrm{CO}_{2}$ gas isotopic composition taken from Thorstenson et al., 1998.

\begin{tabular}{|c|c|c|}
\hline Phase & Composition & $\delta^{13} \mathrm{C}($ per mil $)$ \\
\hline 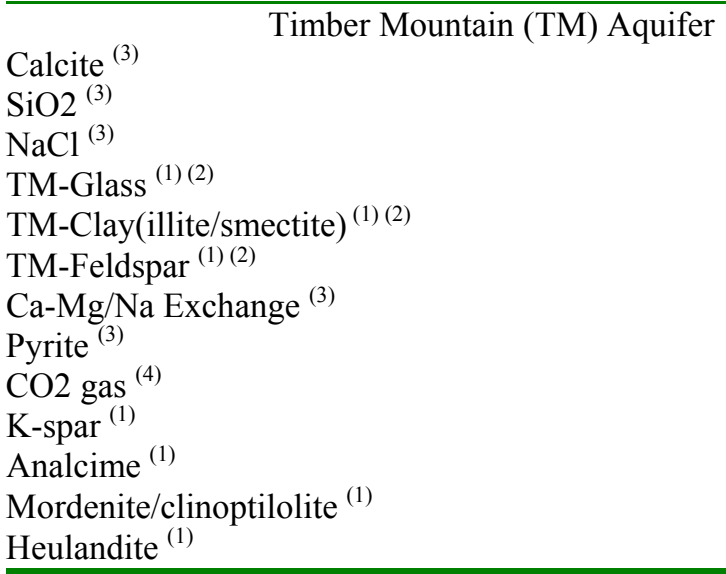 & $\begin{array}{c}\mathrm{CaSr}_{0.0 x x} \mathrm{CO}_{3} \\
\mathrm{SiO}_{2} \\
\mathrm{NaCl} \\
\mathrm{K}_{.368} \mathrm{Na}_{.383} \mathrm{Ca}_{.024} \mathrm{Mg}_{.005} \mathrm{Fe}_{.026} \mathrm{Al}_{.789} \mathrm{Si}_{4.173} \mathrm{O}_{10} \\
\mathrm{~K}_{.017} \mathrm{Na}_{.161} \mathrm{Ca}_{.141} \mathrm{Mg}_{.138} \mathrm{Fe}_{.050} \mathrm{Al}_{2.438} \mathrm{Si}_{3.462} \mathrm{O}_{10} \mathrm{qn} \mathrm{H}_{2} \mathrm{O} \\
\mathrm{K}_{.555} \mathrm{Na}_{.428} \mathrm{Ca}_{.021} \mathrm{Fe}_{.006} \mathrm{Al}_{1.007} \mathrm{Si}_{2.980} \mathrm{O}_{8} \\
\mathrm{Ca} / \mathrm{Mg} \text { for } \mathrm{Na} \\
\mathrm{FeS}_{2} \\
\mathrm{CO}_{2} \\
\mathrm{KAlSi}_{3} \mathrm{O}_{8} \\
\mathrm{NaAlSi}_{2} \mathrm{O}_{6} \\
\mathrm{~K}_{.295} \mathrm{Na}_{.217} \mathrm{Ca}_{.083} \mathrm{Al}_{.735} \mathrm{Si}_{4.278} \mathrm{O}_{10} \mathrm{qn} \mathrm{H}_{2} \mathrm{O} \\
\left(\mathrm{Ca}, \mathrm{Na}_{2}, \mathrm{~K}_{2}\right)_{4}\left(\mathrm{Al}_{8} \mathrm{Si}_{28} \mathrm{O}_{72}\right) \mathrm{A}_{24} \mathrm{H}_{2} \mathrm{O}\end{array}$ & $+1.5,+1.2$ to $+2.1^{(1)}$ \\
\hline $\begin{array}{l}\text { Apatite }^{(1)} \\
\text { Akaganeite }^{(1)}\end{array}$ & $\begin{array}{c}\mathrm{Ca}_{5}\left(\mathrm{PO}_{4}\right)_{3}(\mathrm{OH}, \mathrm{F}, \mathrm{Cl}) \\
(\mathrm{FeOOH}(\mathrm{Ca}-\text { bearing, w/hollandite structure })\end{array}$ & \\
\hline $\begin{array}{l}\text { Calcite }^{(3)} \quad \text { Paintbrush (PB) Aquifer } \\
\mathrm{SiO}^{(3)} \\
\mathrm{NaCl}^{(3)} \\
\mathrm{PB}-G l a s s^{(1)(2)} \\
\text { PB-Clay(illite/smectite) } \\
\text { PB-Feldspar (2) (2) }^{(1)} \\
\mathrm{Ca}-\mathrm{Mg} / \mathrm{Na} \text { Exchange }^{(3)} \\
\text { Pyrite } \\
\mathrm{CO} 2 \text { gas }^{(4)} \\
\mathrm{K}^{(4)}{ }^{(1)} \\
\text { Analcime }^{(1)} \\
\text { Mordenite/clinoptilolite }^{(1)}\end{array}$ & $\begin{array}{c}\mathrm{CaSr}_{0.0 x x} \mathrm{CO}_{3} \\
\mathrm{SiO}_{2} \\
\mathrm{NaCl} \\
\mathrm{K}_{.369} \mathrm{Na}_{.423} \mathrm{Ca}_{.026} \mathrm{Mg}_{.003} \mathrm{Fe}_{.034} \mathrm{Al}_{.816} \mathrm{Si}_{4.123} \mathrm{O}_{10} \\
\mathrm{~K}_{.017} \mathrm{Na}_{.161} \mathrm{Ca}_{141} \mathrm{Mg}_{.138} \mathrm{Fe}_{.050} \mathrm{Al}_{2.438} \mathrm{Si}_{3.462} \mathrm{O}_{10} \mathrm{qn} \mathrm{H}_{2} \mathrm{O} \\
\mathrm{K}_{.490} \mathrm{Na}_{.479} \mathrm{Ca}_{.024} \mathrm{Fe}_{.007} \mathrm{Al}_{1.003} \mathrm{Si}_{2.982} \mathrm{O}_{8} \\
\mathrm{Ca} / \mathrm{Mg} \text { for Na} \\
\mathrm{FeS}_{2} \\
\mathrm{CO}_{2} \\
\mathrm{KAlSi}_{3} \mathrm{O}_{8} \\
\mathrm{NaAlSi}_{2} \mathrm{O}_{6} \\
\mathrm{~K}_{.295} \mathrm{Na}_{.217} \mathrm{Ca}_{.083} \mathrm{Al}_{.735} \mathrm{Si}_{4.278} \mathrm{O}_{10} \mathrm{qn} \mathrm{H}_{2} \mathrm{O}\end{array}$ & $+6.5,+5$ to $+8^{(1)}$ \\
\hline $\begin{array}{ll} & \text { Belted Range (BR) Aquifer } \\
\text { Calcite }^{(3)} & \\
\mathrm{SiO} 2 & (3) \\
\mathrm{NaCl}^{(3)} & \end{array}$ & $\begin{array}{c}\mathrm{CaSr}_{0.0 \mathrm{xx}} \mathrm{CO}_{3} \\
\mathrm{SiO}_{2} \\
\mathrm{NaCl}\end{array}$ & $-2.7^{(1)}$ \\
\hline
\end{tabular}


Table 1-3. Summary of micrographic and isotopic analyses of fracture-coating phases. Data are from IT Corp. (1998), ${ }^{(1)}$ Warren et al. (1998), ${ }^{(2)}$ or assumed for modeling purposes. ${ }^{(3),(4)}$ Data for $\mathrm{CO}_{2}$ gas isotopic composition taken from Thorstenson et al., 1998 (continued).

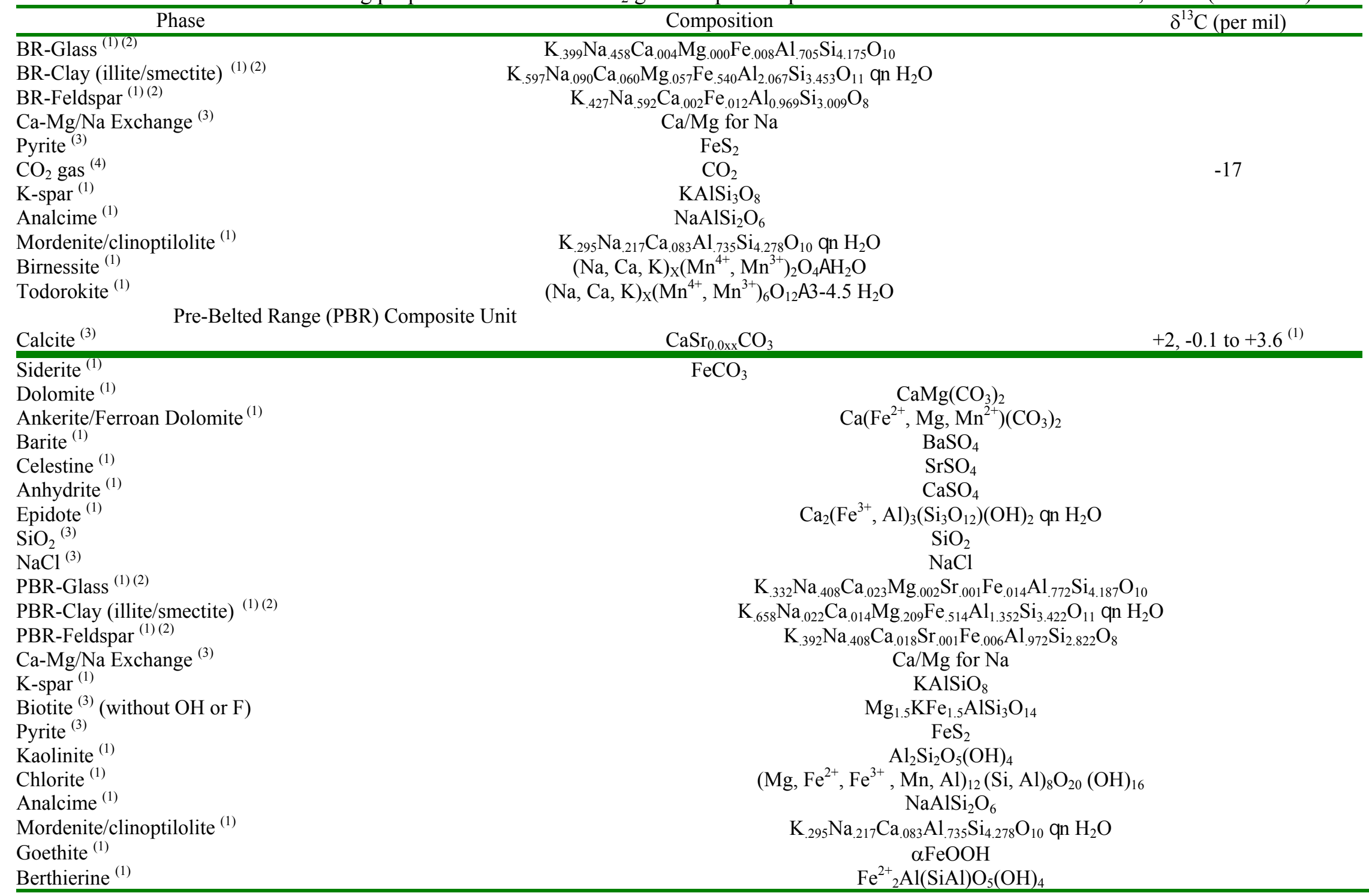


A single sample was collected (UE-20f) from the saturated portion of the Belted Range Aquifer. This sample is characterized by intense fracturing and the predominance of $\mathrm{Fe}$ - and $\mathrm{Mn}$ oxyhydroxides with subordinate calcite + quartz + feldspars + mixed illite/smectite. This sample is important in that, because of the intense fracturing and abundance of secondary oxide phases at considerable depth (over 2,600 $\mathrm{m}(8,600 \mathrm{ft}$ ) below ground surface (bgs)), it suggests the presence of a significantly transmissive hydrogeologic feature or interval. The predominance of secondary oxide phases is also important because of their affinity for the adsorption of dissolved solutes. Because of the limited number of drill holes evaluated and sampled, and the lack of continuous cores from UE-20f, it is not possible at this time to determine how representative this sample is of the Belted Range Aquifer.

Six samples from two different drill holes (UE-20f, PM-2) were collected that represent the saturated portion of the Pre-Belted Range Composite Unit. Fracture-coating phases within the Pre-Belted Range Composite Unit are characterized by carbonate minerals (of $\mathrm{Ca}, \mathrm{Mg}, \mathrm{Fe}$, and $\mathrm{Mn})+$ quartz + sulfate minerals (of $\mathrm{Ca}, \mathrm{Ba}$, and $\mathrm{Sr})+$ pyrite + chlorite + epidote + mixed illite/smectite + local Fe-oxides. The style and occurrence of these phases are more indicative of an active hydrothermal environment than the precipitation from a groundwater system. It is entirely plausible that the older elements of the volcanic stratigraphy (e.g., the Pre-Belted Range Composite Unit) in the Pahute Mesa area will have been affected by the recurrent volcanic activity focused in this general area.

SEM analyses of calcite present in these samples reveal textures that indicate widespread dissolution of calcite. The presence of multiple generations of calcite and other carbonate minerals would suggest that these aquifer systems are at or near equilibrium with respect to calcite. Speciation calculations (see Section 4.2.2) conducted as part of this study show calcite saturation indices increasing from below saturation to saturation along the flowpaths from Pahute Mesa toward Oasis Valley. This would suggest that calcite could be precipitating from groundwater proximal to the discharge area. At this time, micrographic (or isotopic) analyses of calcites from Oasis Valley are unavailable to support this.

Electron microprobe analysis of relatively soluble phases (such as volcanic glass and feldspars) can also be used to constrain the interaction between uncoated fracture surfaces and groundwater. While very limited analyses of volcanic glass were obtained from this group of fractured samples, selected glass analyses from equivalent lithostratigraphic materials have been obtained from Warren et al. (1998). These include: 76 analyses from the Timber Mountain Group; 65 analyses from the Paintbrush Group; 9 analyses from the Belted Range Group; and 7 analyses from pre-Belted Range rocks. The feldspar analyses conducted as part of this study (IT Corp., 1998) have also been complimented by feldspar data from Warren et al. (1998). These include: 263 analyses from the Timber Mountain Group; 189 analyses from the Paintbrush Group; 12 analyses from the Belted Range Group; and 60 analyses from pre-Belted Range rocks. The solid-phase characterization data based on hydrostratigraphic units (HSU) are presented in Table 1-3. The compositions of clay minerals, glass, and feldspars for specific HSUs are identified by a prefix indicating that HSU (e.g., TM-glass for glass in the Timber Mountain HSUs). These data also include HRTEM data from IT Corp. (1998). Where multiple analyses of a phase are present for a particular hydrostratigraphic unit, the analyses have been averaged and normalized to a charge-balanced formula for use in the geochemical flowpath modeling that will be discussed in Chapter 4. 
Table 1-4. Isotopic analyses of fracture-coating calcite.

\begin{tabular}{|c|c|c|c|c|c|c|c|c|c|}
\hline Sample & $\begin{array}{l}\text { Depth } \\
(\mathrm{m})\end{array}$ & $\begin{array}{l}\text { Yield }(\%) \\
\left(\text { as } \mathrm{CaCO}_{3}\right)\end{array}$ & $\begin{array}{c}\delta^{13} \mathrm{C} \\
(\% \circ \mathrm{PDB})\end{array}$ & $\begin{array}{l}{ }^{14} \mathrm{C} \\
\text { (pmc) }\end{array}$ & $\begin{array}{l}{ }^{14} \mathrm{C} \text { age } \\
\text { (yrs) }\end{array}$ & $\begin{array}{c}\delta^{18} \mathrm{O} \\
(\% \mathrm{SMOW})\end{array}$ & $\begin{array}{l}\text { Temp }\left({ }^{\circ} \mathrm{C}\right) \text { for } \\
\delta^{18} \mathrm{O}_{\mathrm{w}}=-15.0\end{array}$ & $\begin{array}{l}\text { Temp }\left({ }^{\circ} \mathrm{C}\right) \text { for } \\
\delta^{18} \mathrm{O}_{\mathrm{w}}=-12.5\end{array}$ & $\begin{array}{l}\text { Temp }\left({ }^{\circ} \mathrm{C}\right) \text { for } \\
\delta^{18} \mathrm{O}_{\mathrm{w}}=-10.0\end{array}$ \\
\hline 7NBS-18 (reference standard) & - & 97.0 & -5.07 & - & - & 7.05 & - & - & - \\
\hline NBS-18 (reference standard) & - & 99.7 & -5.01 & - & - & 7.28 & - & - & - \\
\hline NBS-18 (reference standard) & - & 100.1 & -5.04 & - & - & 7.16 & - & - & - \\
\hline NBS-19 (reference standard) & - & 100.0 & 1.95 & - & - & 28.69 & - & - & - \\
\hline NBS-19 (reference standard) & - & 99.7 & 1.95 & - & - & 28.64 & - & - & - \\
\hline NBS-19 (reference standard) & - & 102.1 & 1.95 & - & - & 28.65 & - & - & - \\
\hline NBS-20 (reference standard) & - & 94.4 & -1.07 & - & - & 26.67 & - & - & - \\
\hline NBS-20 (reference standard) & - & 86.7 & -1.05 & - & - & 26.57 & - & - & - \\
\hline PM-2 $320 \mathrm{ft}$ (upper $1 \mathrm{~mm}$ of vein) & 98 & 62.4 & -5.77 & $-0.08 \pm 0.10$ & $>49,900$ & 19.79 & -1 & 8 & 19 \\
\hline PM-2 $4,180 \mathrm{ft}$ & 1,274 & 63.6 & 3.29 & $-0.11 \pm 0.13$ & $>47,800$ & 1.79 & 101 & 128 & 161 \\
\hline PM-2 5,893ft (whole vein) & 1,796 & 67.0 & 2.03 & - & - & -0.06 & 120 & 151 & 191 \\
\hline PM-2 $5,893 \mathrm{ft}$ ( $0.5 \mathrm{~mm}$ edge of vein) & 1,796 & 34.8 & 1.84 & $-0.08 \pm 0.31$ & $>40,800$ & -0.61 & 127 & 159 & 202 \\
\hline PM-2 5,893 ft (1 mm vein core) & 1,796 & 92.4 & 2.08 & $0.14 \pm 0.08$ & $>46,700$ & 0.20 & 118 & 148 & 187 \\
\hline PM-2 $6,750 \mathrm{ft}$ & 2,057 & 43.4 & 1.75 & $-0.33 \pm 0.20$ & $>44,400$ & -0.53 & 125 & 158 & 200 \\
\hline PM-2 6,750 ft (duplicate) & 2,057 & 44.2 & 1.69 & - & - & -0.76 & 128 & 161 & 204 \\
\hline PM-2 $8,050 \mathrm{ft}$ & 2,454 & 46.8 & -0.22 & - & - & -3.63 & 166 & 211 & 273 \\
\hline PM-2 8,050 ft (duplicate) & 2,454 & 50.0 & -0.26 & - & - & -3.90 & 170 & 217 & 281 \\
\hline PM-2 8,403 ft & 2,561 & 63.0 & 3.57 & - & - & -0.72 & 127 & 161 & 203 \\
\hline PM-3 $1,750 \mathrm{ft}$ & 533 & 16.8 & 8.03 & $0.83 \pm 0.08$ & $38,520 \pm 790$ & 11.76 & 32 & 46 & 62 \\
\hline PM-3 1,750 ft (duplicate) & 533 & 16.6 & 8.05 & - & - & 11.66 & 33 & 47 & 63 \\
\hline PM-3 $1,790 \mathrm{ft}$ & 546 & 72.3 & 5.03 & - & - & 12.05 & 31 & 45 & 60 \\
\hline PM-3 2,860 ft & 872 & 92.1 & 2.76 & $-0.09 \pm 0.10$ & $>49,900$ & 5.00 & 74 & 95 & 120 \\
\hline $\mathrm{UE}-18 \mathrm{t} \quad 1,378 \mathrm{ft}$ & 420 & 95.4 & -2.95 & $-0.12 \pm 0.10$ & $>49,900$ & 11.91 & 32 & 45 & 61 \\
\hline UE-18t $\quad 1,390.5 \mathrm{ft}$ & 424 & 2.5 & -5.47 & - & - & 12.67 & 28 & 41 & 56 \\
\hline UE-18t $2,002 \mathrm{ft}$ & 610 & 90.5 & 1.32 & - & - & 4.20 & 80 & 102 & 129 \\
\hline UE-18t 2,020 ft (lower $2 \mathrm{~mm}$ of vein) & 616 & 69.5 & 2.10 & - & - & 3.49 & 86 & 109 & 138 \\
\hline UE-18t 2,020 ft (upper $2 \mathrm{~mm}$ of vein) & 616 & 80.8 & 1.52 & $-0.10 \pm 0.08$ & $>51,700$ & 4.87 & 75 & 96 & 122 \\
\hline UE-18t 2,020 ft (upper vein duplicate) & 616 & 81.3 & 1.33 & - & - & 4.31 & 79 & 101 & 128 \\
\hline U-19ar $173 \mathrm{ft}$ & 53 & 5.9 & -3.32 & - & - & 21.99 & -8 & 0 & 9 \\
\hline $\mathrm{U}-19$ ar $1,560 \mathrm{ft}$ & 475 & 2.4 & -4.02 & $0.23 \pm 0.13$ & $>42,700$ & 15.30 & 16 & 27 & 41 \\
\hline $\mathrm{U}-20$ as $300 \mathrm{ft}$ & 91 & 21.5 & -4.57 & - & - & 17.35 & 7 & 18 & 30 \\
\hline U-20as $300 \mathrm{ft}$ (duplicate) & 91 & 22.4 & -3.87 & - & - & 18.17 & 4 & 15 & 26 \\
\hline UE-20f $8,665 \mathrm{ft}$ & 2,641 & 91.3 & -2.65 & $0.09 \pm 0.10$ & $>46,900$ & 5.33 & 72 & 92 & 117 \\
\hline UE-20f $13,674 \mathrm{ft}$ & 4,168 & 70.2 & 2.16 & - & - & -0.21 & 122 & 153 & 194 \\
\hline
\end{tabular}

Duplicate analyses represent independent measurements of sample splits. 
The SEM, electron microprobe, and HRTEM analyses have also identified specific zeolite, Fe- and Mn-oxyhydroxide, and clay minerals in these samples. These minerals are significant because of their potential to adsorb dissolved constituents from through-going groundwater.

\subsection{Results of Isotopic Analyses of Fracture-coating Calcite}

\subsubsection{Stable Isotope Results - Distinction Between Saturated and Unsaturated Conditions}

Stable isotope results are reported in Table $1-4$. Calcite $\delta^{13} \mathrm{C}$ values range from -5.8 to $+8.0 \%$, and $\delta^{18} \mathrm{O}$ values range from -3.9 to $+22.0 \%$. On a plot of $\delta^{13} \mathrm{C}$ versus $\delta^{18} \mathrm{O}$, the data are separated into three groups on the basis of isotopic composition (Figure 1-9), reflecting the different environmental conditions under which the calcite formed. These groups include (1) unsaturated zone calcites with $\delta^{13} \mathrm{C}$ values between approximately -6 and $-3 \%$;

(2) unsaturated zone calcites with $\delta^{13} \mathrm{C}$ values greater than $+5 \%$; and (3) saturated zone calcites with $\delta^{13} \mathrm{C}$ values between -3 and $+4 \%$.

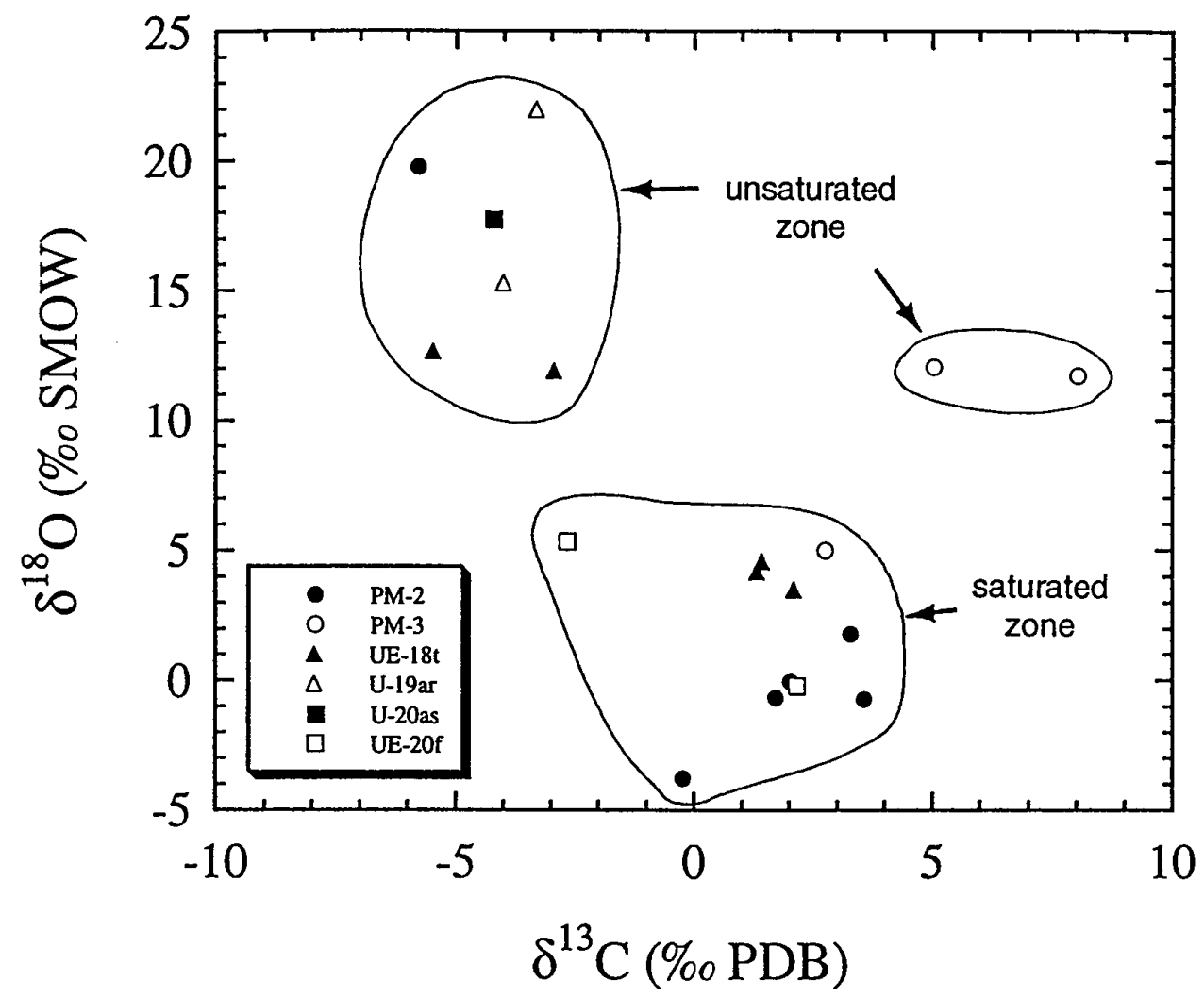

Figure 1-9. Plot of $\delta^{18} \mathrm{O}$ versus $\delta^{13} \mathrm{C}$ values for Pahute Mesa calcite samples. The data are grouped according to differences in isotopic values that reflect different environmental conditions of formation.

The transition from unsaturated to saturated conditions at the time of calcite deposition is inferred on the basis of isotopic composition. Modern water table depths on Pahute Mesa are typically between 600 and $700 \mathrm{~m}$ below the surface (Blankennagel and Weir, 1973), but are notably shallower in UE-18t (280 m), PM-2 (260 m) and PM-3 (444 m). Only four samples from this study lie above the current water table: PM-2 (98 m), U-19ar (53 m and $475 \mathrm{~m})$, and U-20as $(91 \mathrm{~m})$. However, calcite $\delta^{18} \mathrm{O}$ values suggest that a total of eight samples originally precipitated 
in the unsaturated zone. The other four samples were collected below the current water table from UE-18t (420 and $424 \mathrm{~m}$ ), and PM-3 (533 and $546 \mathrm{~m}$ ). The key indication is a discontinuity in the calcite $\delta^{18} \mathrm{O}$ values at a depth of $\sim 600 \mathrm{~m}$.

All Pahute Mesa calcites from below $600 \mathrm{~m}$ depth have $\delta^{18} \mathrm{O}$ values less than $+6 \%$, whereas shallower samples have $\delta^{18} \mathrm{O}$ values greater than $+11 \%$. These variations are consistent with data from Yucca Mountain, Nevada (Figure 1-10), where saturated zone calcites have $\delta^{18} \mathrm{O}$ values less than $+10 \%$ (Szabo and Kyser, 1990; Whelan and Stuckless, 1992; Paces et al., 1996). The similarity in isotopic variations at Pahute Mesa and Yucca Mountain suggests similar conditions for calcite formation at both locations. However, saturated zone calcites from Pahute Mesa tend to be lower in $\delta^{18} \mathrm{O}$ than those from Yucca Mountain (Figure 1-10), reflecting either greater sampling depths, higher paleo-geothermal gradients, or a combination of the two.

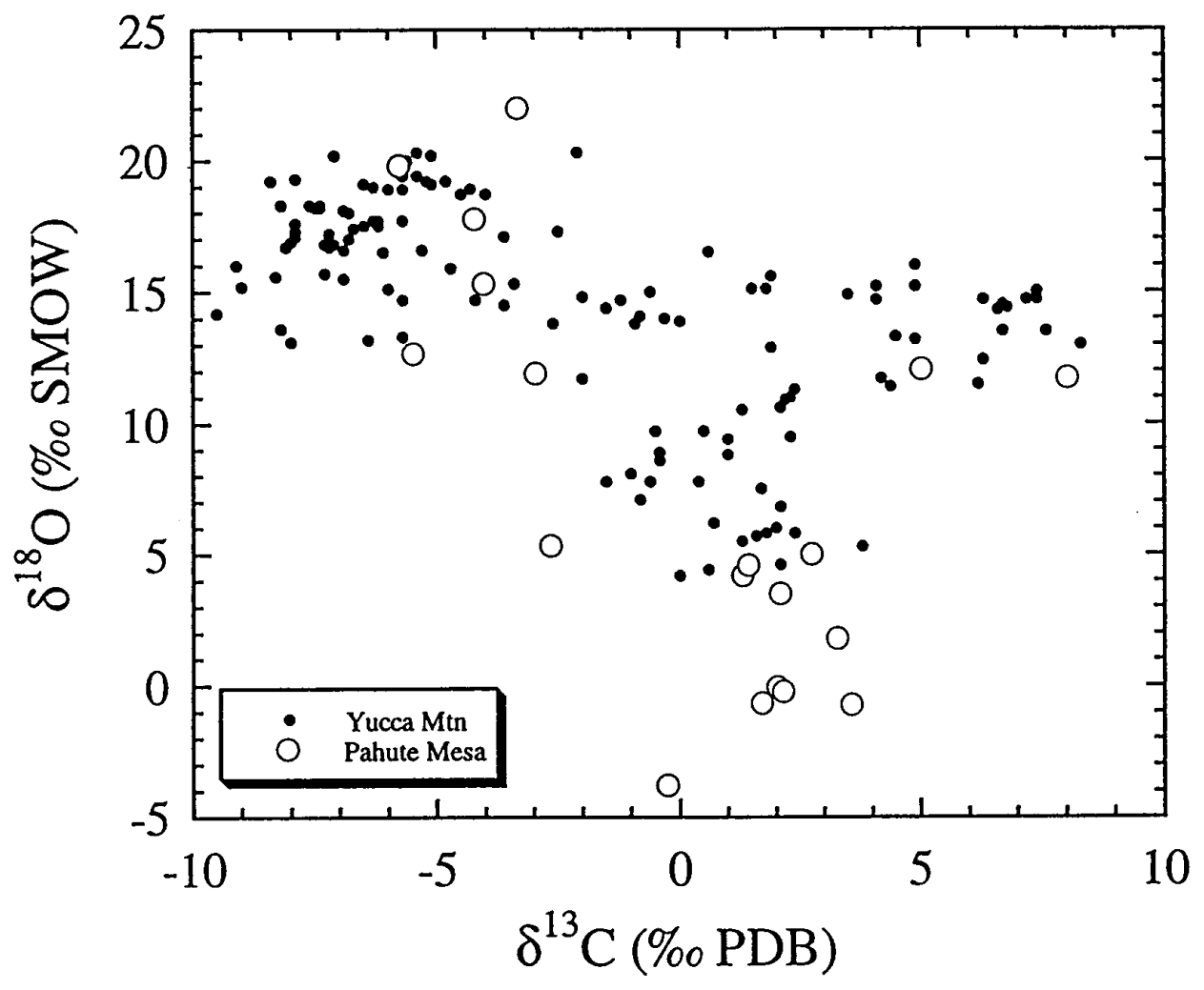

Figure 1-10. Plot of $\delta^{18} \mathrm{O}$ versus $\delta^{13} \mathrm{C}$ for calcite samples from Pahute Mesa and Yucca Mountain. The similarity in isotopic variations between the two data sets suggests similar depositional conditions at both locations. Yucca Mountain data were compiled from published results in Szabo and Kyser (1990), Whelan and Stuckless (1992) and Paces et al. (1996).

\subsubsection{Unsaturated Zone Calcite}

Most unsaturated zone calcites from Pahute Mesa have $\delta^{13} \mathrm{C}$ values between -6 and $-3 \%$. This range in values is consistent with a pedogenic (soil zone) carbon source. Pedogenic carbonate forms in arid environments during mineral weathering processes involving soil $\mathrm{CO}_{2}$ (Salomons and Mook, 1986). The carbon isotopic composition of the soil carbonate is determined by the soil $\mathrm{CO}_{2}$ gas composition, and reflects the type of vegetation in the area 
(Cerling, 1984). Quade et al. (1989) showed that pedogenic carbonate $\delta^{13} \mathrm{C}$ values decrease systematically with increasing elevation in southern Nevada, ranging from about -3 to $-7 \%$ at elevations between 1,500 to 2,000 $\mathrm{m}$. This is the approximate range in surface elevations for wells represented in this study, and is consistent with the observed range in $\delta^{13} \mathrm{C}$ values for many unsaturated zone calcites from this study.

Calcite in the deep unsaturated zone probably accumulates slowly over time as dissolved inorganic carbon in percolating waters carries soil carbonate down along fractures in the rock (Whelan and Stuckless, 1992). This implies that surface recharge periodically infiltrates to great depths in the unsaturated zone. The $\delta^{18} \mathrm{O}$ values of unsaturated zone calcites from Pahute Mesa are generally consistent with this interpretation, and will be discussed below.

Two calcite samples from the unsaturated zone have relatively enriched $\delta^{13} \mathrm{C}$ values of +5.0 and +8.0 (Figure 1-9). Both samples are from approximately the same depth interval in well PM3 , and occur in fractured basalt as powdery fracture coatings and vesicle fillings. Similar ${ }^{13} \mathrm{C}$ enriched calcites were also observed in the unsaturated zone at Yucca Mountain (Paces et al., 1996). The isotopically heavy $\delta^{13} \mathrm{C}$ values suggest that calcite precipitation occurred during methane-producing chemical reactions, such as the decarboxylation of short-chain aliphatic acids (e.g., $\mathrm{CH}_{3} \mathrm{COO}^{-}+\mathrm{H}_{2} \mathrm{O} \rightarrow \mathrm{HCO}_{3}{ }^{-}+\mathrm{CH}_{4}$, Carothers and Kharaka, 1980). Isotopic fractionation of ${ }^{12} \mathrm{C}$ into $\mathrm{CH}_{4}$ during this process causes coexisting bicarbonate ions to become highly enriched in ${ }^{13} \mathrm{C}$ (Bottinga, 1969). Unsaturated zone calcites from the Bandelier tuff in New Mexico were recently found to contain methane-rich fluid inclusions, suggesting that isotopically enriched calcite may form during the microbial decomposition of organic matter (Newman et al., 1997).

\subsubsection{Saturated Zone Calcite}

Calcite samples from the saturated zone at Pahute Mesa have $\delta^{13} \mathrm{C}$ values between -3 and $+4 \%$, although most of the data cluster around +1 to $+4 \%$ (Figure 1-9). These values are similar to those of Paleozoic carbonate rocks that underlie the volcanic section (Thomas et al., 1996, Table 17) and suggest the saturated zone calcite precipitated from water containing dissolved inorganic carbon (DIC) originating from the Paleozoic carbonate aquifer (Whelan and Stuckless, 1992). The same process was documented for calcite deposited during former high stands of the water table in Yucca Flat (Smith et al., 1998). Groundwater from the Paleozoic carbonate aquifer has $\delta^{13} \mathrm{C}$ values ranging from -0.7 to $-6.1 \%$, with an average value around $-3.8 \%$ o $(n=30)$ (Winograd and Pearson, 1976; Benson and McKinley, 1985; Rose et al., 1997, 1999). Calcite is enriched in ${ }^{13} \mathrm{C}$ by $\sim 1 \%$ relative to dissolved bicarbonate at $25^{\circ} \mathrm{C}$ (Rubinson and Clayton, 1969), and shows increasing ${ }^{13} \mathrm{C}$ enrichment at higher temperatures (Mook, 1986) or during $\mathrm{CO}_{2}$ exsolution. Precipitation temperatures of 75 to $150^{\circ} \mathrm{C}$ will account for most saturated zone calcite $\delta^{13} \mathrm{C}$ values, assuming a carbonate aquifer carbon source. This range in temperatures is in general agreement with temperatures estimated from calcite $\delta^{18} \mathrm{O}$ data, and suggests an elevated geothermal gradient during calcite deposition (see below).

\subsubsection{Paleo-temperature Estimates from Calcite $\delta^{18} \mathrm{O}$ Results}

When calcite is formed, oxygen isotopes are partitioned (fractionated) between the calcite and coexisting water according to temperature. The oxygen isotope composition of a calcite therefore provides a record of the temperature at which the calcite formed. A precise determination of this temperature requires knowledge of $\delta^{18} \mathrm{O}$ value of the water. However, if the 
water $\delta^{18} \mathrm{O}$ value can be reasonably estimated, the $\delta^{18} \mathrm{O}$ value of the calcite provides a useful paleo-temperature indicator.

The $\delta^{18} \mathrm{O}$ values of Pahute Mesa calcites generally decrease with increasing depth, in response to increasing temperature. In the saturated zone, calcite $\delta^{18} \mathrm{O}$ values range from +5.3 to $-3.9 \%$ and plot along a steeply dipping trend (Figure 1-11), although the pattern is not consistent from well to well. For example, calcite samples from well UE-20f (open squares) appear to lie along a lower thermal gradient compared to most other saturated zone samples.

\section{$\delta^{18} \mathrm{O}(\% \circ \mathrm{SMOW})$}

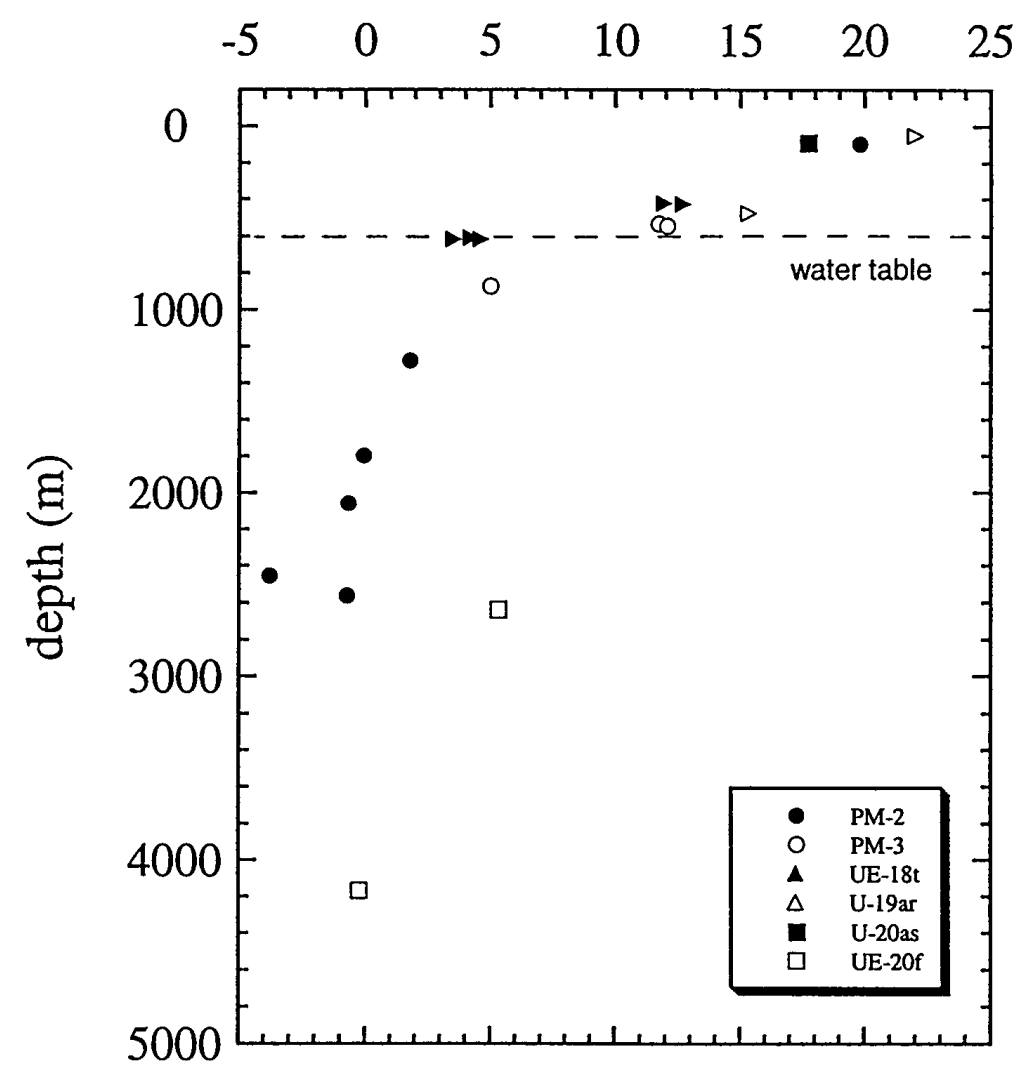

Figure 1-11. Plot of $\delta^{18} \mathrm{O}$ versus sample depth for Pahute Mesa calcite samples. The $\delta^{18} \mathrm{O}$ values generally decrease with increasing depth, in response to increasing temperature. The inferred transition from unsaturated to saturated conditions during calcite formation is marked by the dashed line (water table) at $600 \mathrm{~m}$ depth, and is based on similarities to Yucca Mountain calcite data.

The temperature-dependent calcite-water fractionation equation developed by O'Neil et al. (1969) was used to estimate calcite deposition temperatures. The results are reported in Table 1-4. As previously noted, the exact $\delta^{18} \mathrm{O}$ value of the water from which the calcite formed is unknown, but it can be estimated. Modern groundwater from the volcanic aquifers on Pahute Mesa has a $\delta^{18} \mathrm{O}$ value near $-15 \%$ (Rose et al., 1997). It is assumed that saturated zone calcites formed from water of this composition, although this value may have varied through time. Calcite in the unsaturated zone formed from meteoric waters percolating down from the surface. Modern meteoric water from Pahute Mesa has an average $\delta^{18} \mathrm{O}$ value around -12.5\% (Benson 
and Klieforth, 1989; Ingraham et al., 1991). Evaporation during groundwater infiltration will cause isotopic enrichment, yielding somewhat higher $\delta^{18} \mathrm{O}$ values. Due to uncertainties in

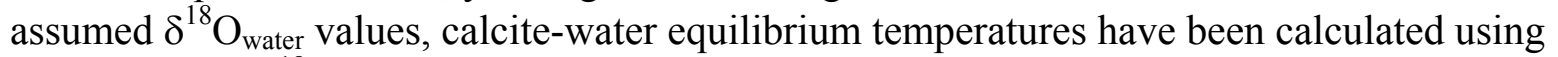
three different $\delta^{18} \mathrm{O}_{\text {water }}$ compositions: $-15,-12.5$ and -10\%o (Table 1-4).

In the unsaturated zone, paleo-temperature estimates range from 0 to $47^{\circ} \mathrm{C}$ for $\delta^{18} \mathrm{O}_{\text {water }}=$ $-12.5 \%$, and from 9 to $63^{\circ} \mathrm{C}$ for $\delta^{18} \mathrm{O}_{\text {water }}=-10 \%$. Some near-surface samples (from depths $<100 \mathrm{~m}$ ) yield unrealistically low temperature estimates, indicating that the calcite formed from highly evaporated water $\left(\delta^{18} \mathrm{O}>-10 \%\right.$ ). Excluding these samples and assuming $\delta^{18} \mathrm{O}_{\text {water }}=$ $-12.5 \%$, the calcite-water equilibrium temperatures suggest a paleo-geothermal gradient between 55 and $70^{\circ} \mathrm{C} / \mathrm{km}$ for the unsaturated zone. This calculation assumes a mean annual surface temperature of $15^{\circ} \mathrm{C}$ (Sass et al., 1980). The estimated paleo-geothermal gradient for Pahute Mesa is notably higher than the modern geothermal gradient at Yucca Mountain, where borehole gradients range from 36 to $45^{\circ} \mathrm{C} / \mathrm{km}$ (Sass et al., 1980). Szabo and Kyser (1990) showed that unsaturated zone calcite from Yucca Mountain fits a model geothermal gradient of $34^{\circ} \mathrm{C} / \mathrm{km}$. These results imply that many of the unsaturated zone calcites from Pahute Mesa formed at a time when geothermal gradients were higher than they are today.

Saturated zone calcite paleo-temperatures range from 72 to $170^{\circ} \mathrm{C}$, assuming $\delta^{18} \mathrm{O}_{\text {water }}=$ $-15 \%$, with the highest temperatures occurring in samples from well PM-2. Figure 1-12 shows variations in calcite $\delta^{18} \mathrm{O}$ values versus depth over a range of geothermal gradients. The curves in Figure 1-12 indicate the $\delta^{18} \mathrm{O}$ values of calcite in equilibrium with -15\%o groundwater along geothermal gradients of $22,34,45,60$ and $75^{\circ} \mathrm{C} / \mathrm{km}$, assuming a surface temperature of $15^{\circ} \mathrm{C}$. Samples from wells PM-2 and PM-3 are consistent with a gradient between approximately 45 and $70^{\circ} \mathrm{C} / \mathrm{km}$, similar to that of the unsaturated zone samples. Samples from UE-20f fall along a shallower geothermal gradient ranging from 22 to $28^{\circ} \mathrm{C} / \mathrm{km}$, whereas UE-18t samples plot above the $75^{\circ} \mathrm{C} / \mathrm{km}$ geotherm and suggest a gradient as high as $135^{\circ} \mathrm{C} / \mathrm{km}$. The latter samples lie very close to the inferred paleo-water table, and indicate that temperatures much higher than those associated with the present geothermal gradient have occurred at relatively shallow depths.

The isotopic systematics of the fracture coating and/or filling calcites analyzed as part of this study have been influenced by a complex sequence of events over time. Calcite has been formed in relation with and subjected to the spatial thermal regimes associated with caldera formation. Depending on the location both within a given caldera and relative to later calderas, the thermal event recorded by a given calcite sample may not have a direct genetic relationship to its immediate host rocks. This may be why the highest apparent thermal gradient has been preserved in intra-caldera samples from the Timber Mountain caldera moat collected from drill hole UE-18t. Calcite from this location would be likely to preserve the thermal signature from the nearby, relatively young thermal event associated with the Timber Mountain resurgent dome.

Electron microprobe studies, discussed in section 1.8, revealed cation-substitution effects in some calcite samples, or the presence of other carbonate minerals coexisting with calcite (e.g., dolomite, siderite). Fractionation factors reported by Rosenbaum and Sheppard (1986) suggest that cation substitution should not significantly influence the temperature estimates reported above. Moreover, samples prepared for isotopic analysis during this study were reacted with $\mathrm{H}_{3} \mathrm{PO}_{4}$ at $25^{\circ} \mathrm{C}$ for time periods of $<24$ hours. The reaction kinetics for pure carbonate minerals 
other than calcite are sufficiently slow at $25^{\circ} \mathrm{C}$ (Al-Aasm et al., 1990), assuming most of the $\mathrm{CO}_{2}$ produced during reaction was from calcite.

\section{$\delta^{18} \mathrm{O}(\% \circ \mathrm{SMOW})$}

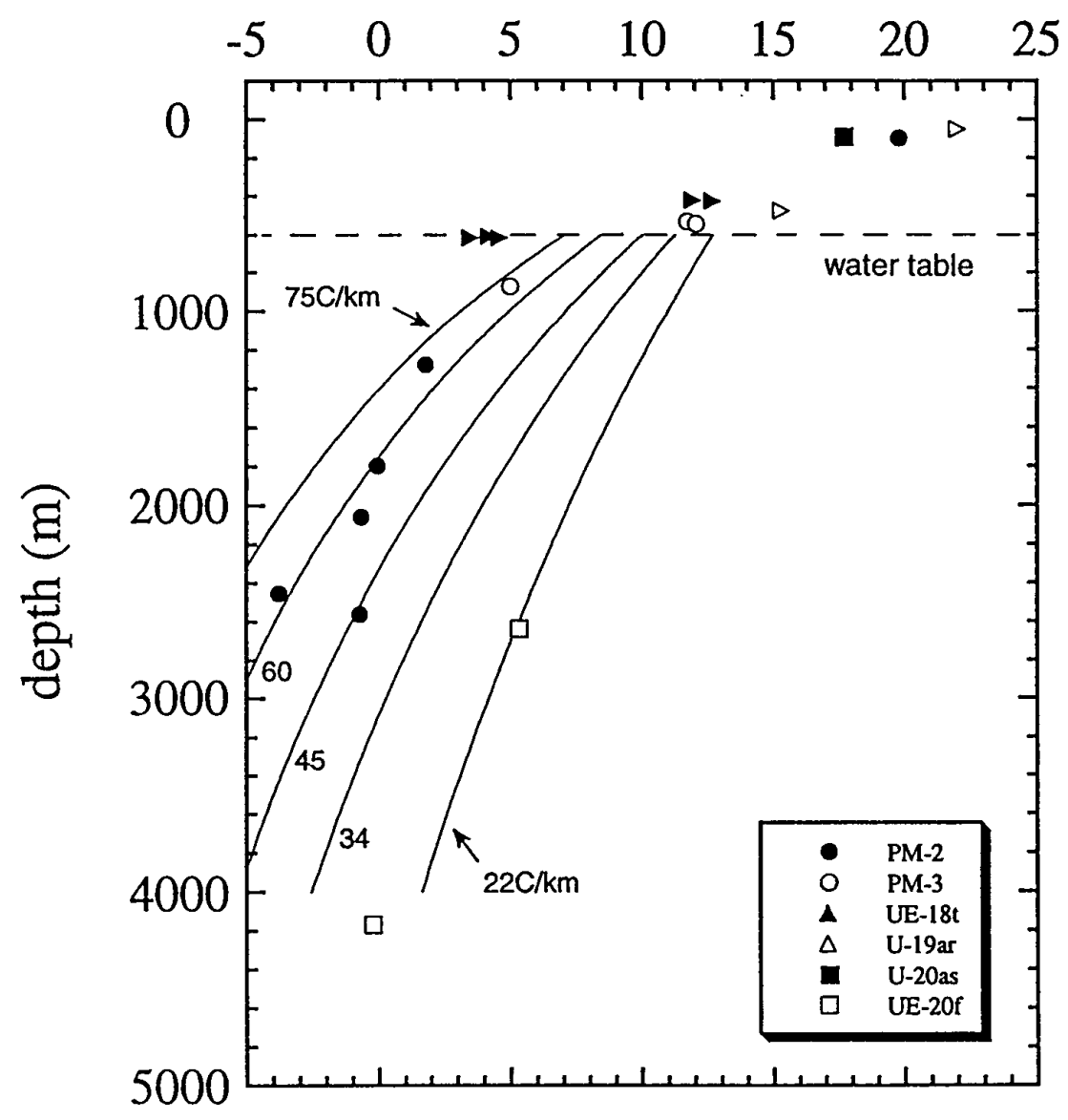

Figure 1-12. Same plot as shown in Figure 1-11, but with curves indicating the $\delta^{18} \mathrm{O}$ values of saturated zone calcites in equilibrium with $-15 \%$ groundwater along geothermal gradients of 22,34 , 45,60 and $75^{\circ} \mathrm{C} / \mathrm{km}$. Mean annual surface temperature is assumed to be $15^{\circ} \mathrm{C}$. A number of the saturated zone samples fall along elevated geotherms of $>45^{\circ} \mathrm{C} / \mathrm{km}$, indicating hydrothermal deposition. Temperatures estimated from the calcite-water isotopic fractionation factor range as high as $170^{\circ} \mathrm{C}$. Samples from UE-20f fall along a lower geothermal gradient ranging from 22 to $28^{\circ} \mathrm{C} / \mathrm{km}$. These samples may have been deposited from ambient groundwater, although wall-rock alteration implies hydrothermal deposition from ${ }^{18} \mathrm{O}$-shifted groundwater is more likely for the $4,168 \mathrm{~m}$ sample.

\subsubsection{Radiocarbon}

A total of 11 radiocarbon measurements were performed on 10 different samples to determine whether any of the Pahute Mesa calcites exhibit measurable ${ }^{14} \mathrm{C}$ ages $(<42,500$ years $)$. Much of the calcite in veins from the saturated zone is relatively homogeneous in structure. These textures imply a single episode of calcite deposition. Two saturated zone samples and one unsaturated zone sample showed clear evidence for depositional layering, and efforts were taken to carefully separate and analyze material from the upper surface of each vein. Two of these 
samples were from well PM-2 (98 $\mathrm{m}$ and 1,796 $\mathrm{m}$ ) and one was from well UE-18t (616 m). Radiocarbon analyses of the outer portion of each of these veins yielded ${ }^{14} \mathrm{C}$ activities below the detection limit. In fact, only one sample showed a radiocarbon value above the analytical detection limit of $\sim 0.5 \mathrm{pmc}$. This sample is inferred to have formed in the unsaturated zone (well $\mathrm{PM}-3,533 \mathrm{~m}$ ) and has a ${ }^{14} \mathrm{C}$ activity of $0.83 \mathrm{pmc}$, yielding a 38,500-year age. This sample also showed an unusually enriched $\delta^{13} \mathrm{C}$ value of $+8 \%$, implying calcite deposition during methanogenesis.

\subsection{Summary}

Fracture-coating mineral phases on 23 archived samples from six drill holes in the Pahute Mesa area were analyzed using micrographic and isotopic techniques. These fracture-coating mineral-phase assemblages in the major hydrostratigraphic units have the potential to impart a geochemical signature to through-going groundwaters. This may result from isotopic exchange during water-rock interaction, adsorption of solutes by zeolites and/or Fe- and Mnoxyhydroxides, or dissolution of relatively soluble phases such as sulfides, carbonates, volcanic glass, and feldspars. Three of the principal volcanic aquifers hosting groundwater flow are represented by the samples collected.

Fracture-coating phases within the Timber Mountain Aquifer system are characterized by calcite + mixed illite/smectite + opaline silica in the unsaturated zone and by calcite + mixed illite/smectite + quartz + feldspars + zeolites + Fe- and Mn-oxyhydroxides in the saturated zone.

A single sample from the saturated portion of the Belted Range Aquifer is characterized by intense fracturing and the predominance of Fe- and Mn-oxyhydroxides with subordinate calcite + quartz + feldspars + mixed illite/smectite. This suggests the presence of a significant transmissive hydrogeologic feature or stratigraphic interval. The predominance of secondary oxide phases in this sample also has important connotations for the potential adsorption of dissolved solutes.

Fracture-coating phases within the Pre-Belted Range Composite Unit are characterized by phases more indicative of a hydrothermal environment rather than precipitation from a groundwater system. This is suggested by the presence of pyrite, chlorite, and epidote in addition to quartz, illite/smectite, carbonate and sulfate minerals.

Micrographic analysis has revealed calcite textures, indicating that carbonate dissolution is widespread on Pahute Mesa. Secondary calcite was separated from these samples and analyzed for its $\delta^{13} \mathrm{C}, \delta^{18} \mathrm{O}$ and ${ }^{14} \mathrm{C}$ values. In the unsaturated zone, calcite was deposited by downward percolation of meteoric water at low to moderate temperatures. Most of the unsaturated zone calcites have $\delta^{13} \mathrm{C}$ values that reflect a pedogenic (soil zone) source, although two samples have unusually high $\delta^{13} \mathrm{C}$ values derived from microbial decomposition of organic matter.

In contrast, saturated zone calcites were deposited by regional groundwater, and have $\delta^{13} \mathrm{C}$ signatures derived from Paleozoic rocks that underlie the volcanic section. Most of the saturated zone samples have $\delta^{18} \mathrm{O}$ values that reflect deposition from hydrothermal fluids at temperatures as high as $170^{\circ} \mathrm{C}$. The variation in $\delta^{18} \mathrm{O}$ with depth indicates paleo-geothermal gradients between 45 and $70^{\circ} \mathrm{C} / \mathrm{km}$ for many samples, and as high as $135^{\circ} \mathrm{C} / \mathrm{km}$ for a few samples. These results suggest calcite deposition occurred during or shortly after periods of active volcanism in this area. The high geothermal gradients that were present during calcite deposition no longer exist in the modern environment beneath Pahute Mesa. 
Radiocarbon measurements on ten different samples revealed that most of the calcite is older than the age resolution of the ${ }^{14} \mathrm{C}$ dating method $\left(>42,500\right.$ years). One sample has a ${ }^{14} \mathrm{C}$ activity of 0.83 pmc, yielding a 38,500-year age. Absolute ages are still unknown for the remaining samples.

Calcite isotopic values can be correlated to hydrostratigraphic intervals to provide information for modeling calcite interaction with modern groundwater. Under current water level conditions, calcite from the shallow saturated zone shows a range in $\delta^{13} \mathrm{C}$ values reflecting deposition under both saturated and unsaturated conditions. In deeper aquifer units, calcite samples have $\delta^{13} \mathrm{C}$ signatures derived from Paleozoic carbonate rocks.

One sample from highly fractured rock in the deep saturated zone has a $\delta^{18} \mathrm{O}$ value that indicates deposition from deep circulation of modern groundwater. Other samples define the presence of multiple thermal gradients in the Pahute Mesa area that may be a result of recurring volcanic activity in the southwest Nevada volcanic field.

The isotopic data presented in this report provide a useful reference point for evaluating calcite dissolution and isotopic exchange processes in the western Pahute Mesa-Oasis Valley flow system. From this standpoint, the most significant results are the $\delta^{13} \mathrm{C}$ and ${ }^{14} \mathrm{C}$ compositions of the saturated zone calcites. These calcite samples have been categorized (IT Corp., 1998) according to their host rocks, thereby providing a means of correlating calcite isotopic values with specific hydrostratigraphic units. These units include: (1) the Timber Mountain Aquifer; (2) the Upper Paintbrush Confining Unit; (3) the Calico Hills Confining Unit; (4) the Belted Range Aquifer; and (5) the Pre-Belted Range Composite Unit.

Figure 1-13 is a plot of $\delta^{13} \mathrm{C}$ versus sample depth wherein data points are identified according to hydrostratigraphic unit. The variability in calcite $\delta^{13} \mathrm{C}$ compositions within the Timber Mountain Aquifer reflects calcite deposition under both unsaturated and saturated conditions. At depths greater than 1,000 m, most of the calcite samples are from the Pre-Belted Range Composite Unit (Figure 1-13). Most of these samples reflect a hydrothermal origin, with a carbon source derived from the Lower Carbonate Aquifer. A single sample from the Belted Range Aquifer (UE-20f, 2,641 m) has a $\delta^{18} \mathrm{O}$ value that suggests deposition from deep circulation of modern groundwater. The host rock for this calcite is a highly fractured rhyolite containing abundant oxide minerals. These characteristics are consistent with a zone that is transmissive to groundwater flow.

As will be discussed in Chapter 3, groundwater samples from wells on Pahute Mesa are highly variable in their $\delta^{13} \mathrm{C}$ values, ranging from -11.1 to $-1.4 \%$, with ${ }^{14} \mathrm{C}$ values between 25 and 9 pmc (Rose et al., 1997, 1998a). Groundwater $\delta^{13} \mathrm{C}$ values generally get heavier (become less negative) as ${ }^{14} \mathrm{C}$ values decrease - a pattern that is consistent with aquifer calcite dissolution reactions. Groundwater samples from wells that lie between Oasis Valley and Pahute Mesa also show considerable evidence for calcite dissolution or isotopic exchange reactions with a heavy carbon source with low levels of ${ }^{14} \mathrm{C}$ (e.g., ER-OV-1: $\delta^{13} \mathrm{C}=-1.4 \%,{ }^{14} \mathrm{C}=5 \mathrm{pmc}$; see Appendix $\mathrm{B}-1)$. The extent to which calcite dissolution/exchange reactions may influence groundwater ages is addressed in Chapter 4. 


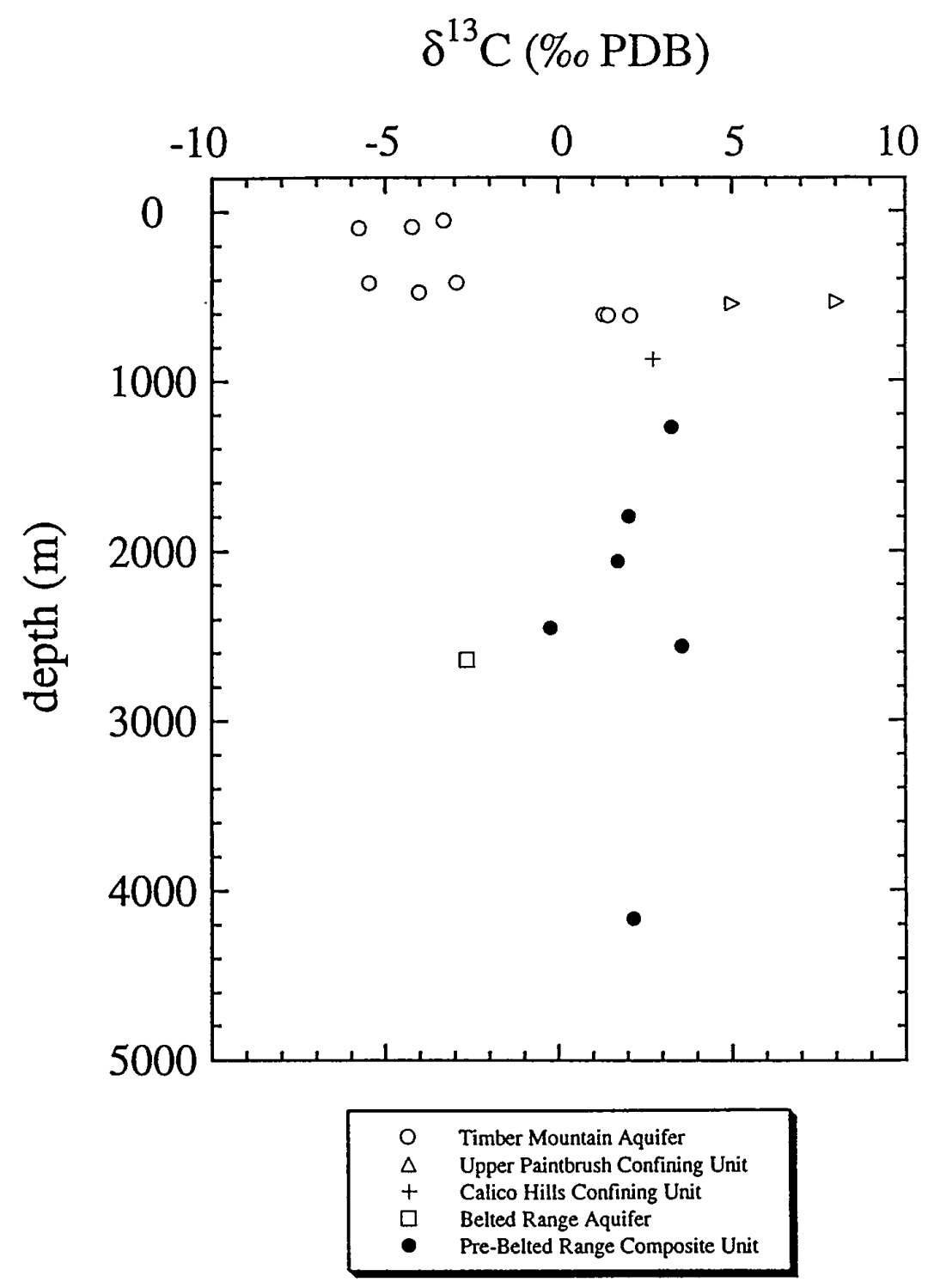

Figure 1-13. Plot of $\delta^{13} \mathrm{C}$ versus sample depth for Pahute Mesa calcite samples. Data points are labeled with respect to hydrostratigraphic units to show the range in $\delta^{13} \mathrm{C}$ compositions for different aquifer units.

Water chemistry data generated by the Desert Research Institute (Appendix B-1) indicate that most of the Oasis Valley groundwaters are saturated with respect to calcite (see section 4.2.2). This saturation state may simply reflect calcite dissolution processes in the Pahute Mesa aquifers. However, as will be discussed in Chapter 3, Oasis Valley basin groundwaters are notably elevated in ${ }^{3} \mathrm{He}$. This implies that a mantle-derived gas flux enters the groundwater system along deep crustal fault zones (Rose et al., 1998a). Since mantle helium is generally accompanied by $\mathrm{CO}_{2}$ gas (e.g., Hilton, 1996; Sorey et al., 1998) this process may cause groundwater $\mathrm{pH}$ values to decrease, which will promote calcite dissolution. It is therefore of interest to know something about secondary calcite that occurs downgradient from Pahute Mesa. Sidewall core and cuttings samples from the ER-OV wells and the new ER-EC wells should be examined for the presence of secondary minerals, particularly calcite. If calcite is found, isotopic 
measurements on those samples may provide new information regarding the evolution of the groundwater chemistry in the region between Pahute Mesa and the Oasis Valley discharge zone.

Additional information on the origin and age of secondary calcite samples could be obtained from ${ }^{87} \mathrm{Sr} /{ }^{86} \mathrm{Sr}$ measurements and uranium-series dating. The former method is useful in discriminating between different carbonate sources, while the latter is useful in dating carbonate material with ages up to $\sim 600,000$ years $\left({ }^{230} \mathrm{Th} /{ }^{238} \mathrm{U}\right.$ disequilibrium method). The uranium-series dating technique may be particularly useful in understanding the sequential depositional history of multi-layer calcite veins. 


\section{CHAPTER 2 \\ CHEMICAL AND ISOTOPIC COMPOSITION OF GROUNDWATER RECHARGE TO THE OASIS VALLEY FLOW SYSTEM, SOUTHERN NEVADA}

\subsection{Introduction}

The Oasis Valley flow system is of particular importance because of the potential movement of radionuclides through the system from the Nevada Test Site (NTS), principally from the Pahute Mesa underground nuclear testing area, to springs and wells in Oasis Valley. To interpret the movement of groundwater in the flow system using aqueous geochemistry and environmental isotopes, the nature of the groundwater recharge end members must be characterized. This paper summarizes new and historical chemical and isotopic data of both precipitation and groundwater to identify the groundwater recharge inputs to the Oasis Valley flow system. Data were collated from various published articles from DRI, LLNL, and USGS reports and unpublished data, and from the IT Group Geochem98 database. Analytical results from groundwater samples collected during the Oasis Valley flow system study as discussed in Chapter 1 and Chapter 3 were also used.

The study area of the Oasis Valley flow system examined in this report encompasses approximately 6,000 square kilometers in southern Nevada and includes part of the NTS and Nellis Air Force Range (NAFR). Upland areas that provide groundwater recharge to the flow system include Pahute Mesa on the NTS and the Kawich and Cactus ranges on the NAFR. Groundwater flow is thought to flow south and southwestward from the recharge areas to springs discharging in Oasis Valley. Since shallow groundwater recharge data are very sparse in the Oasis Valley flow system, other areas outside of, but close to, the flow system are considered including Rainier Mesa, Timber Mountain, and Shoshone Mountain. Precipitation data include major-ion concentrations and stable isotopic ratios of $\delta \mathrm{D}$ and $\delta^{18} \mathrm{O}$. Groundwater data include major-ion analyses, $\delta \mathrm{D}$ and $\delta^{18} \mathrm{O}$, tritium activity, and ${ }^{14} \mathrm{C}$ content.

\subsection{Methodology}

Data generated during the Oasis Valley flow system study were collected and analyzed as described in Chapter 3. Historical data and descriptions of sample collection and analysis by the DRI are found in Chapman and Lyles (1993), Ingraham et al. (1991), Lyles et al. (1990), Sadler (1990), Russell (1987), and Raker (1987); by LLNL in Rose et al. (1997) and Davisson et al. (1994); by the USGS in McKinley and Oliver (1995), Whelan et al. (1995), McKinley and Oliver (1994), Benson and Klieforth (1989), and Milne et al. (1987); and by the IT Group (F. C. Benedict Jr., personal communication, 1999).

\subsection{Results}

\subsubsection{Chemical and Isotopic Composition of Precipitation}

Available data include $366 \delta \mathrm{D}$ and $\delta^{18} \mathrm{O}$ pairs, 24 additional $\delta \mathrm{D}$ values, and 123 additional $\delta^{18} \mathrm{O}$ values for precipitation collected from $10 / 27 / 1981$ to $12 / 12 / 1994$. No single sample location encompassed the entire sampling period. Precipitation data evaluated were limited to samples collected above 1,829 m because most recharge is thought to occur above this elevation (Blankennagel and Weir, 1973) except for occasional high-intensity, short-duration precipitation events that recharge lower elevation drainages like Fortymile Wash (Claassen, 1985). Sample locations (Figure 2-1. Map of precipitation sampling locations for the Oasis Valley flow system. - located in the back of this report) include four on Pahute Mesa, three on Rainier Mesa, one on 
Timber Mountain, two on Shoshone Mountain, and two on the Kawich Range. Locations, elevations, number of samples and time period of collection are listed in Table 2-1.

Table 2-1. Precipitation sampling location, collection dates, and number of samples for each location for the Oasis Valley flow system.

\begin{tabular}{|c|c|c|c|c|c|c|}
\hline Sample & Latitude & Longitude & Elevation (m) & Start Date & End Date & \# of Samples \\
\hline $\begin{array}{l}\text { TT1 } \\
\text { Timber Mountain }\end{array}$ & 370332 & 1162637 & 1,840 & $10 / 28 / 1981$ & $8 / 5 / 1986$ & $\begin{array}{l}36 \delta^{18} \mathrm{O} \\
19 \delta \mathrm{D}\end{array}$ \\
\hline $\begin{array}{l}\mathrm{Ki} \\
\text { Pahute Mesa }\end{array}$ & 371605 & 1161900 & 2,145 & $2 / 13 / 1984$ & $5 / 6 / 1986$ & $\begin{array}{l}52 \delta^{18} \mathrm{O} \\
46 \delta \mathrm{D}\end{array}$ \\
\hline $\begin{array}{l}\text { PT1 } \\
\text { Pahute Mesa }\end{array}$ & 371346 & 1161800 & 2,200 & $10 / 27 / 1981$ & 8/17/1987 & $\begin{array}{l}55 \delta^{18} \mathrm{O} \\
42 \delta \mathrm{D}\end{array}$ \\
\hline $\begin{array}{l}\text { PT2 } \\
\text { Pahute Mesa }\end{array}$ & 371704 & 1162104 & 2,060 & 10/27/1981 & 8/17/1987 & $\begin{array}{l}53 \delta^{18} \mathrm{O} \\
41 \delta \mathrm{D}\end{array}$ \\
\hline $\begin{array}{l}\text { PT3 } \\
\text { Pahute Mesa }\end{array}$ & 371323 & 1162721 & 1,890 & $10 / 27 / 1981$ & 7/23/1987 & $\begin{array}{l}45 \delta^{18} \mathrm{O} \\
35 \delta \mathrm{D}\end{array}$ \\
\hline $\begin{array}{l}\text { ST1 } \\
\text { Shoshone Mountain }\end{array}$ & 365641 & 1161536 & 2,135 & $10 / 28 / 1981$ & $7 / 23 / 1987$ & $\begin{array}{l}40 \delta^{18} \mathrm{O} \\
33 \delta \mathrm{D}\end{array}$ \\
\hline $\begin{array}{l}\text { ST2 } \\
\text { Shoshone Mountain }\end{array}$ & 365621 & 1161500 & 1,830 & $10 / 27 / 1981$ & 7/23/1987 & $\begin{array}{l}44 \delta^{18} \mathrm{O} \\
34 \delta \mathrm{D}\end{array}$ \\
\hline $\begin{array}{l}\text { RT1 } \\
\text { Rainier Mesa }\end{array}$ & 371214 & 1161211 & 2,235 & $10 / 27 / 1981$ & $7 / 23 / 1987$ & $\begin{array}{l}52 \delta^{18} \mathrm{O} \\
38 \delta \mathrm{D}\end{array}$ \\
\hline $\begin{array}{l}\text { RT2 } \\
\text { Rainier Mesa }\end{array}$ & 370931 & 1161301 & 1,900 & 10/27/1981 & 8/17/1987 & $\begin{array}{l}51 \delta^{18} \mathrm{O} \\
41 \delta \mathrm{D}\end{array}$ \\
\hline $\begin{array}{l}\text { Stockade Pass } \\
\text { Rainier Mesa }\end{array}$ & 370951 & 1161211 & 2,051 & 8/27/1993 & $12 / 12 / 1994$ & $\begin{array}{l}9 \delta^{18} \mathrm{O} \\
9 \delta \mathrm{D}\end{array}$ \\
\hline $\begin{array}{l}\text { Kawich Peak } \\
\text { Kawich Range }\end{array}$ & 375719 & 1162700 & 2,755 & $10 / 1 / 1988$ & 9/17/1992 & $\begin{array}{l}18 \delta^{18} \mathrm{O} \\
18 \delta \mathrm{D}\end{array}$ \\
\hline $\begin{array}{l}3 \text { Springs Creek } \\
\text { Kawich Range }\end{array}$ & 375737 & 1162523 & 2,155 & 1/19/1985 & 9/17/1992 & $\begin{array}{l}34 \delta^{18} \mathrm{O} \\
34 \delta \mathrm{D}\end{array}$ \\
\hline
\end{tabular}

$\delta \mathrm{D}$ for all sites ranges from -177 to $-9 \%$ (isotopic results are expressed as $\%$ as recommended by ISO 1992) with a mean of $-87 \%$. $\delta^{18} \mathrm{O}$ ranges from -23.5 to $+2.2 \%$ with a mean of $-12.1 \%$. All data regardless of season or amount are included. Ranges, means, and standard deviations for each geographic recharge area are listed in Table 2-2. Figure 2-2 shows available data pairs, the global meteoric water line (GMWL) defined by Craig $(1961), \delta \mathrm{D}=$ $8 \delta^{18} \mathrm{O}+10$, and a local meteoric water line of $\delta \mathrm{D}=7.1 \delta^{18} \mathrm{O}-2.7$ based on these data. This plot shows that most precipitation lies on or above the GMWL, indicating that higher-elevation precipitation in the area has not been evaporated during atmospheric rainout. The weighted isotopic means for all available data are $-94 \%$ o $\delta$ and $-12.9 \%$ o $\delta^{18} \mathrm{O}$. Weighted isotopic means are calculated by multiplying the precipitation amount by the isotopic ratio for each sample, adding these values together, and then dividing that total by the total amount of precipitation. The weighted isotopic means are $7 \%$ lighter for $\delta \mathrm{D}$ and $0.8 \%$ lighter for $\delta^{18} \mathrm{O}$ than the arithmetic isotopic means demonstrating the larger amount of isotopically lighter winter precipitation relative to the heavier summer precipitation. The weighted means for the various locations are listed in Table 2-3. The elevation gradient (Figures 2-3 and 2-4) for these data is $3.8 \% / 100 \mathrm{~m}$ $\delta \mathrm{D}$ and $1.0 \%$ o $/ 100 \mathrm{~m} \delta^{18} \mathrm{O}$; however, these data are poorly correlated $\left(\delta^{18} \mathrm{O} \mathrm{r}^{2}=0.23\right.$ and $\delta \mathrm{D} \mathrm{r}=$ $0.58)$. 
Table 2-2. Ranges, means, and standard deviation of precipitation $\delta^{18} \mathrm{O}$ and $\delta \mathrm{D}$ for each geographic recharge area for the Oasis Valley flow system.

\begin{tabular}{lllllllll}
\hline & $\begin{array}{l}\delta^{18} \mathrm{O} \\
\text { Min } \\
\text { Recharge Area }\end{array}$ & $\begin{array}{c}\delta^{18} \mathrm{O} \\
\mathrm{Max} \\
(\%)\end{array}$ & $\begin{array}{c}\delta^{18} \mathrm{O} \\
\text { Mean } \\
(\%)\end{array}$ & $\begin{array}{c}\delta^{18} \mathrm{O} \\
\mathrm{SD} \\
(\%)\end{array}$ & $\begin{array}{c}\delta \mathrm{D} \\
\text { Min } \\
(\%)\end{array}$ & $\begin{array}{c}\delta \mathrm{D} \\
\mathrm{Max} \\
(\%)\end{array}$ & $\begin{array}{c}\delta \mathrm{D} \\
\text { Mean } \\
(\%)\end{array}$ & $\begin{array}{c}\delta \mathrm{D} \\
\mathrm{SD} \\
(\%)\end{array}$ \\
\hline Pahute Mesa & -21.8 & 2.2 & -11.7 & 4.5 & -156 & -12 & -84 & 32 \\
Rainier Mesa & -23.5 & -1.0 & -12.5 & 4.0 & -177 & -18 & -89 & 31 \\
Shoshone Mt & -21.6 & -1.1 & -11.6 & 3.6 & -165 & -9 & -85 & 27 \\
Timber Mt & -19.8 & -2.5 & -11.5 & 4.2 & -139 & -21 & -83 & 32 \\
Kawich Range & -21.9 & -5.0 & -13.4 & 3.9 & -164 & -34 & -97 & 30 \\
\hline
\end{tabular}

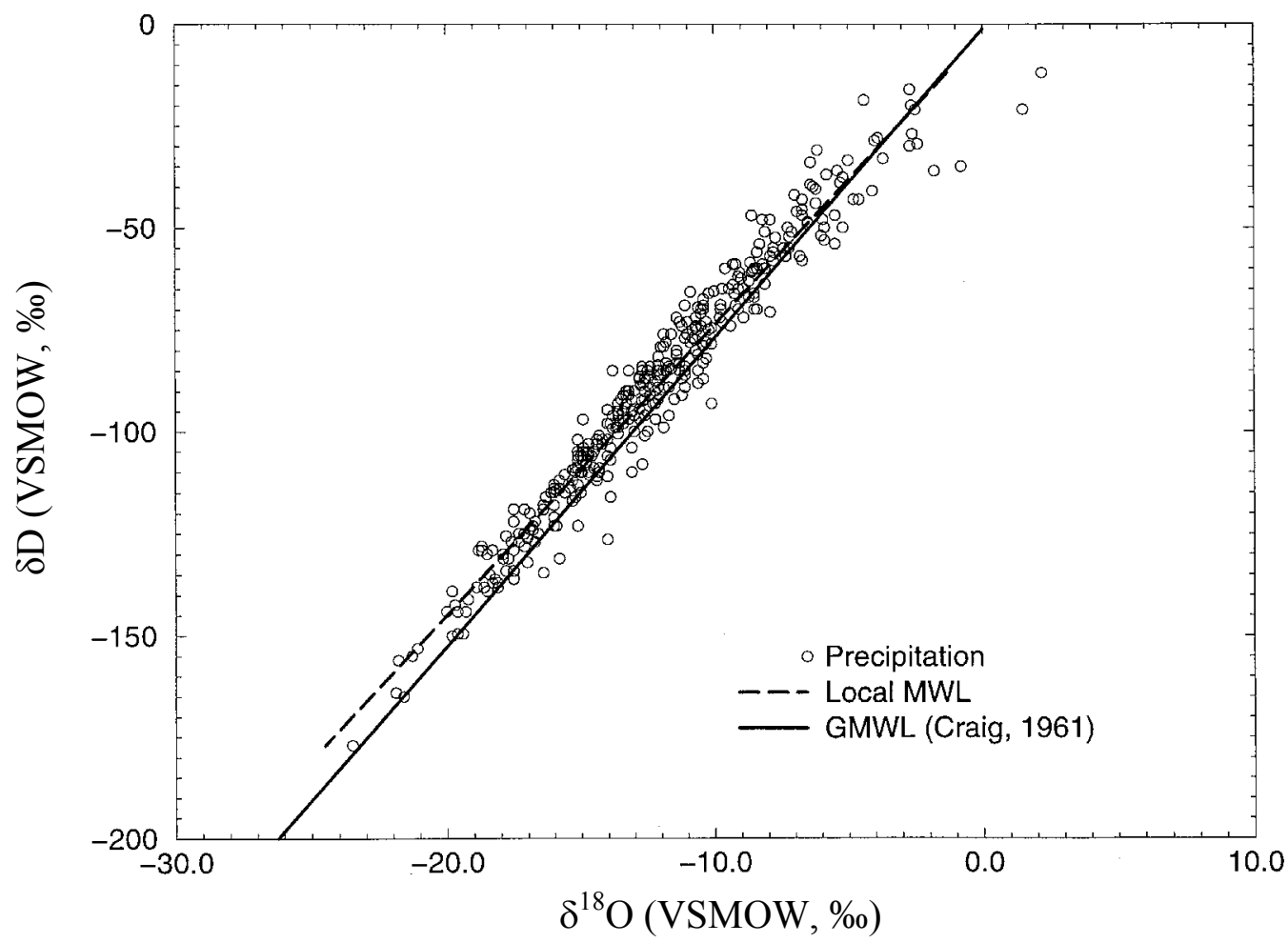

Figure 2-2. $\quad \delta \mathrm{D}$ and $\delta^{18} \mathrm{O}$ of precipitation for the Oasis Valley flow system. 
Table 2-3. Isotopic means weighted by precipitation amount for each sampling location for the Oasis Valley flow system.

\begin{tabular}{lcc}
\hline Sampling Location & $\delta$ D Weighted Mean & $\delta^{18}$ O Weighted Mean \\
\hline TT1 Timber Mountain & -79 & -12.1 \\
Ki Pahute Mesa & -86 & -12.1 \\
PT1 Pahute Mesa & -92 & -12.7 \\
PT2 Pahute Mesa & -88 & -12.9 \\
PT3 Pahute Mesa & -88 & -12.9 \\
RT1 Rainier Mesa & -86 & -11.9 \\
RT2 Rainier Mesa & -85 & -12.9 \\
Stockade Pass Rainier Mesa & -85 & -11.7 \\
ST1 Shoshone Mountain & -86 & -10.1 \\
ST2 Shoshone Mountain & -82 & -11.0 \\
Kawich Peak Kawich Range & -103 & -14.5 \\
3 Springs Creek Kawich Range & -102 & -14.1 \\
\hline
\end{tabular}

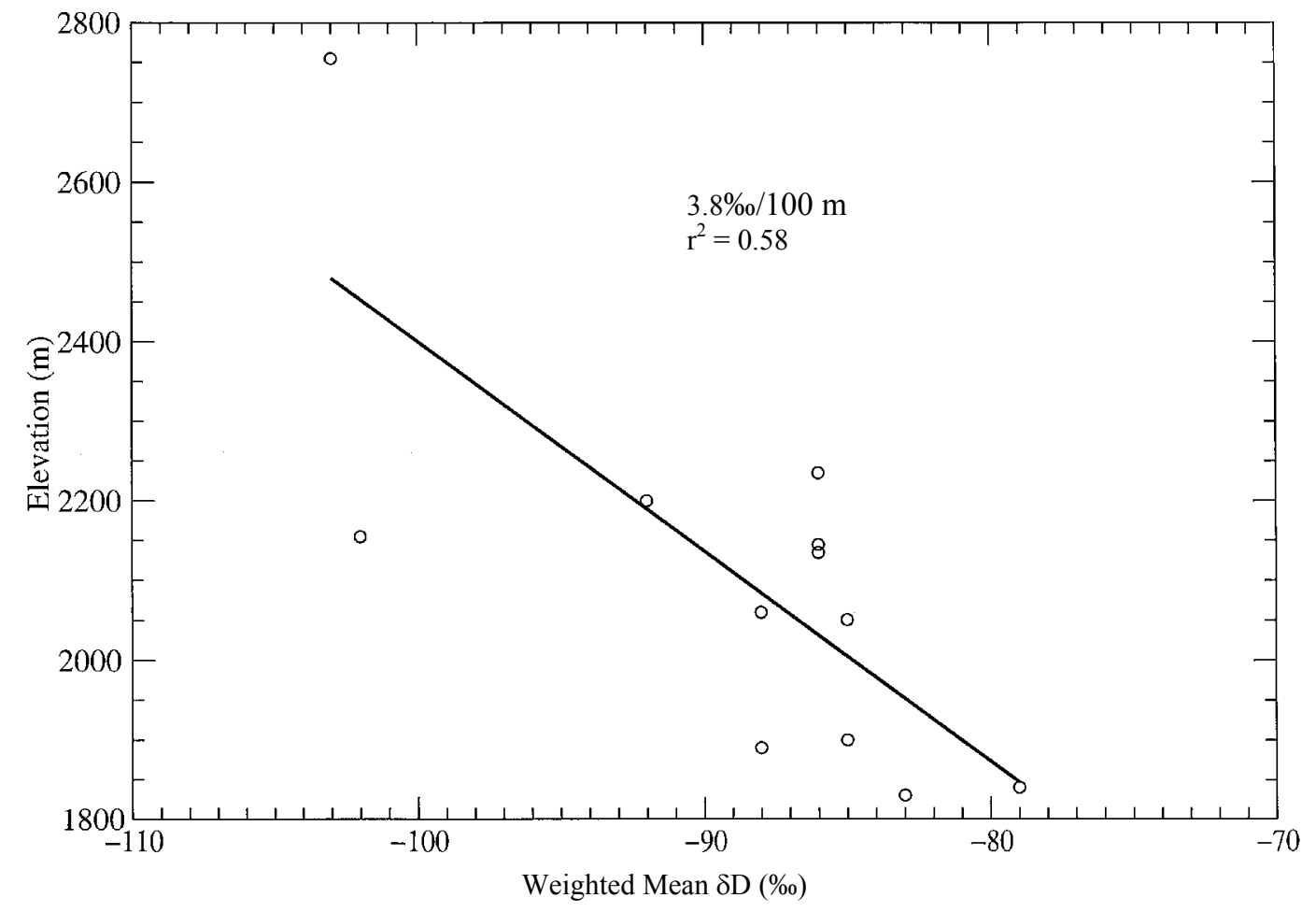

Figure 2-3. Mean $\delta \mathrm{D}$ weighted by precipitation amount vs. elevation for each precipitation sampling location in the Oasis Valley flow system. 


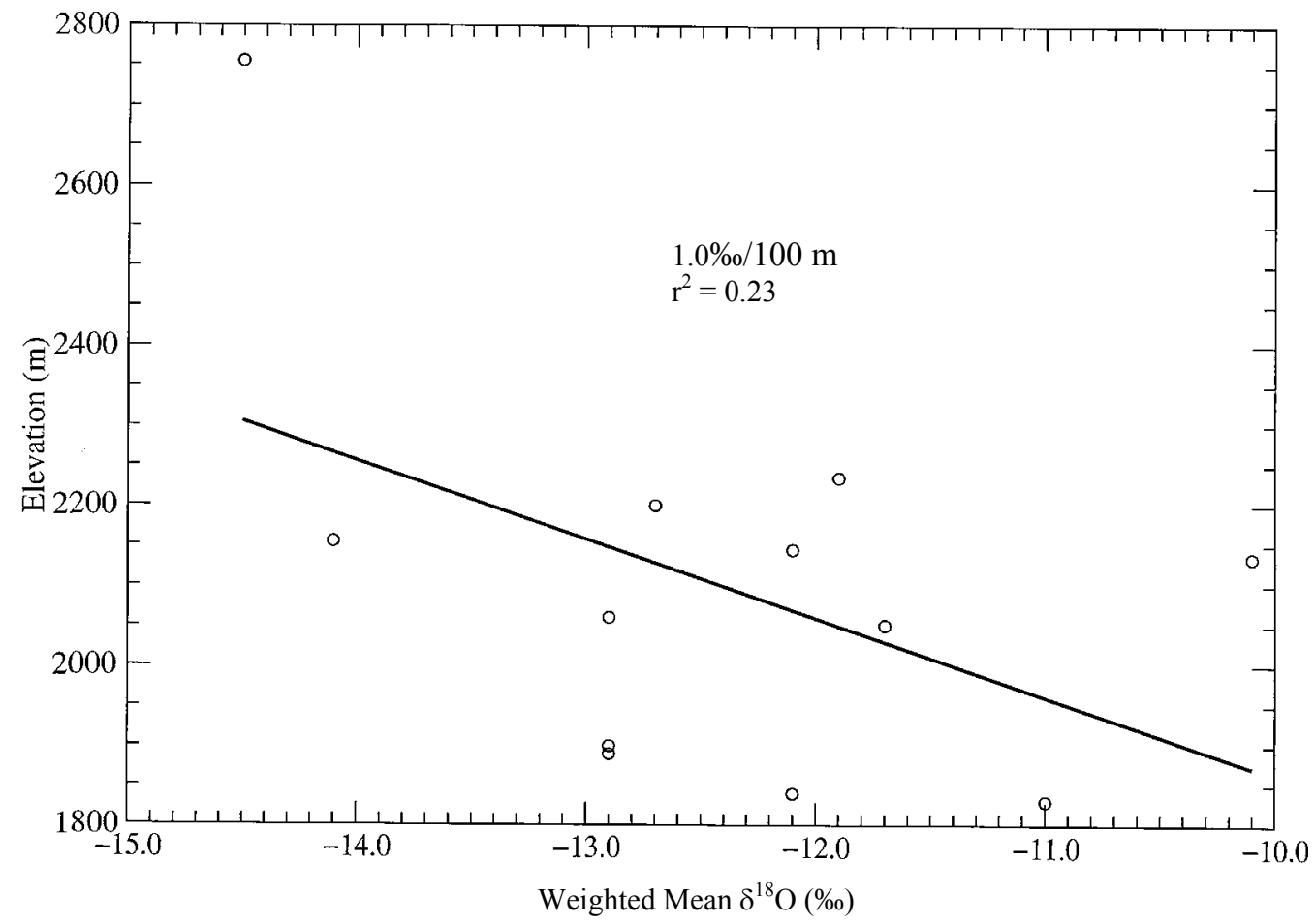

Figure 2-4. Mean $\delta^{18} \mathrm{O}$ weighted by precipitation amount vs. elevation for each precipitation sampling location in the Oasis Valley flow system.

Cool-season precipitation (October through June) originates from the Pacific Ocean and falls from two types of storms, Pacific fronts and Great Basin lows (Winograd et al., 1998; Houghton et al., 1975; Houghton, 1969). The cool-season precipitation-weighted isotopic means are $-105 \%$ o $\delta$ and $-14.3 \%$ o $\delta^{18} \mathrm{O}$. Cool-season $\delta \mathrm{D}$ and $\delta^{18} \mathrm{O}$ pairs are plotted in Figure 2-5. The slope of the data is close to the GMWL slope and exactly the same as the local meteoric water line. Warm-season precipitation (July through September) originates from either the Gulf of California or the Gulf of Mexico and from summer thunderstorms (Winograd et al., 1998; Houghton et al., 1975; Houghton, 1969). The warm-season precipitation-weighted isotopic means are $-65 \%$ o $\delta \mathrm{D}$ and $-9.4 \% \delta^{18} \mathrm{O}$. Warm-season $\delta \mathrm{D}$ and $\delta^{18} \mathrm{O}$ pairs are plotted in Figure 2-6. The warm season data have a slope of -6.5 , which is much lower than the GMWL. Friedman et al. (1992) observed slopes of 5 to 6 for Mojave Desert summer precipitation believed to be caused by evaporation as rain fell from cloud base to ground surface.

Table 2-4 lists major-ion data collected from several NTS precipitation locations. Most samples are higher in dissolved constituents than precipitation at other locations (Hem, 1989). Samples were an aliquot of precipitation collected over approximately a one-month period. The majority of dissolved constituents are most likely the result of accumulation of dust on the precipitation collector, which had a surface area of $0.22 \mathrm{~m}^{2}$ (R. Jacobson, Desert Research Institute, personal communication, 1999). 


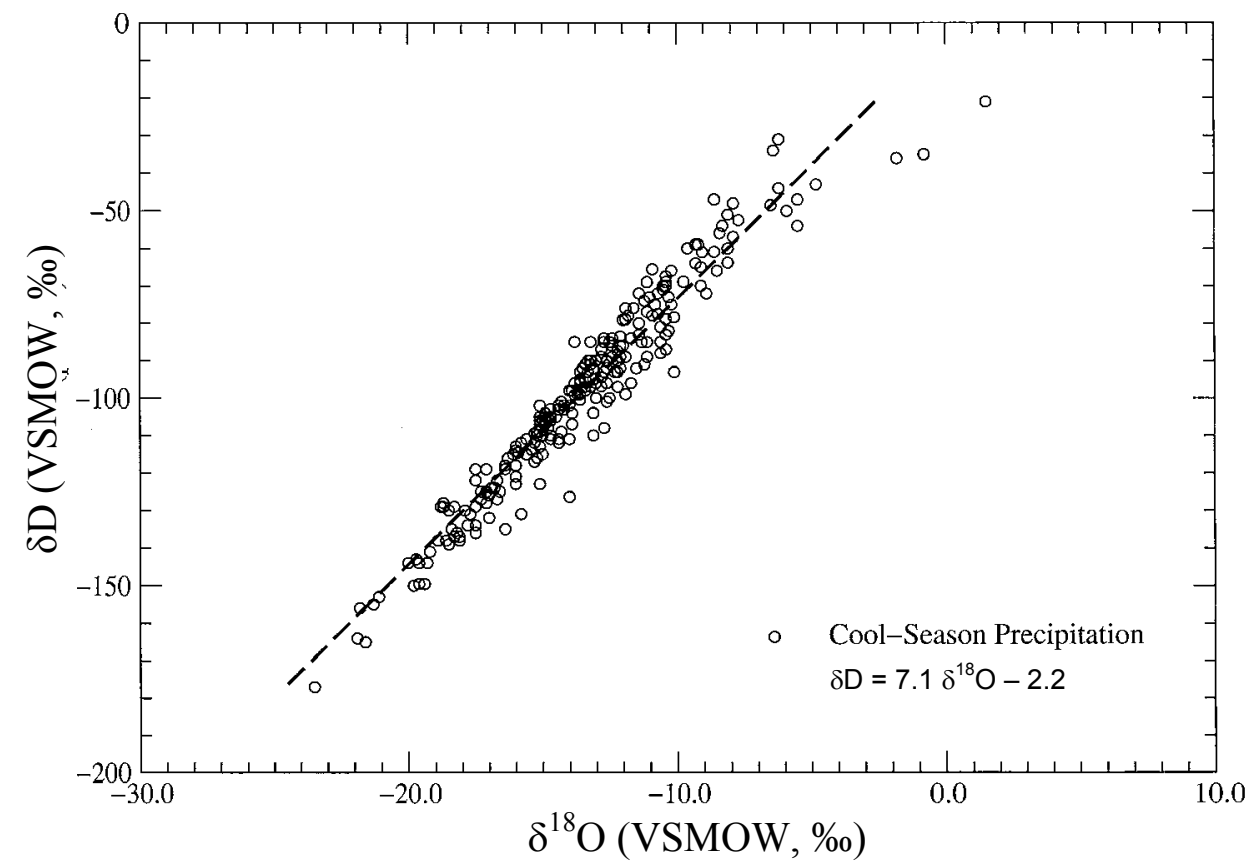

Figure 2-5. $\quad \delta \mathrm{D}$ and $\delta^{18} \mathrm{O}$ of cool-season precipitation (October - June) in the Oasis Valley flow system.

$\sum_{0}^{2}$

$\delta \mathrm{D}=6.5 \delta^{18} \mathrm{O}-6.7$

$\delta^{18} \mathrm{O}(\mathrm{VSMOW}, \%$ )

Figure 2-6. $\quad \delta \mathrm{D}$ and $\delta^{18} \mathrm{O}$ of warm-season precipitation (July - September) in the Oasis Valley flow system. 
Table 2-4. Major-ion chemistry of precipitation collected at the NTS.

\begin{tabular}{lccccccccccc}
\hline Location & Start Date & End Date & $\mathrm{pH}$ & $\begin{array}{c}\mathrm{Ca} \\
(\mathrm{mg} / \mathrm{L})\end{array}$ & $\begin{array}{c}\mathrm{Mg} \\
(\mathrm{mg} / \mathrm{L})\end{array}$ & $\begin{array}{c}\mathrm{Na} \\
(\mathrm{mg} / \mathrm{L})\end{array}$ & $\begin{array}{c}\mathrm{K} \\
(\mathrm{mg} / \mathrm{L})\end{array}$ & $\begin{array}{c}\mathrm{HCO}_{3} \\
(\mathrm{mg} / \mathrm{L})\end{array}$ & $\begin{array}{c}\mathrm{Cl} \\
(\mathrm{mg} / \mathrm{L})\end{array}$ & $\begin{array}{c}\mathrm{SO}_{4} \\
(\mathrm{mg} / \mathrm{L})\end{array}$ & $\begin{array}{c}\mathrm{NO}_{3} \\
(\mathrm{mg} / \mathrm{L})\end{array}$ \\
\hline PT1 & $11 / 14 / 1985$ & $12 / 16 / 1985$ & 6.17 & 0.70 & 0.05 & 0.30 & 0.11 & 1.70 & 0.30 & 0.40 & 0.83 \\
PT1 & $12 / 18 / 1986$ & $01 / 21 / 1987$ & 6.29 & 22.8 & 3.88 & 3.57 & 4.83 & 5.00 & 2.00 & 3.80 & 92.08 \\
& & & & & & & & & & & \\
PT2 & $12 / 18 / 1986$ & $01 / 21 / 1987$ & 7.72 & 60.8 & 4.45 & 4.61 & 7.24 & 67.9 & 1.00 & 8.90 & 141.7 \\
& & & & & & & & & & & \\
RT1 & $11 / 14 / 1985$ & $12 / 16 / 1985$ & 6.83 & 8.59 & 1.21 & 1.54 & 1.25 & 20.5 & 1.30 & 7.30 & 3.88 \\
& & & & & & & & & & & \\
RT2 & $11 / 14 / 1985$ & $12 / 16 / 1985$ & 6.30 & 1.33 & 0.10 & 0.20 & 0.16 & 2.40 & 0.20 & 0.90 & 1.09 \\
RT2 & $12 / 18 / 1986$ & $01 / 21 / 1987$ & 7.91 & 17.5 & 3.04 & 5.70 & 7.28 & 50.9 & 0.90 & 4.00 & 36.52 \\
& & & & & & & & & & & \\
ST1 & $10 / 10 / 1985$ & $12 / 17 / 1985$ & 6.80 & 4.13 & 0.32 & 0.72 & 0.76 & 9.90 & 0.80 & 1.80 & 3.17 \\
ST1 & $12 / 18 / 1986$ & $01 / 21 / 1987$ & 7.37 & 25.4 & 3.79 & 1.94 & 20.4 & 66.9 & 1.80 & 5.40 & 36.70 \\
& & & & & & & & & & & \\
ST2 & $12 / 18 / 1986$ & $01 / 22 / 1987$ & 7.48 & 30.8 & 4.70 & 3.92 & 15.6 & 111 & 3.20 & 9.20 & 12.04 \\
\hline
\end{tabular}

\subsubsection{Chemical and Isotopic Composition of Groundwater Recharge}

Several upland areas are considered to be recharge areas for the Oasis Valley flow system. The chemical and isotopic composition of these areas is described below.

\subsubsection{Kawich Range and Cactus Range}

The Kawich and Cactus ranges are located in the northern portion of the flow system and are composed mostly of volcanic rocks with some outcrops of carbonate and clastic rocks. Numerous perched springs are found in both ranges and the $\delta \mathrm{D}$ and $\delta^{18} \mathrm{O}$ for these springs are plotted on Figure 2-7 with the GMWL. Most springs have only single samples; however, three springs (Sumner Spring, Ledge Spring, and Kawich Creek) have multiple samples (Table 2-5). $\delta \mathrm{D}$ for the Kawich and Cactus ranges varies by $10 \%$ (-108 to $-98 \%$ ) with a mean of $-103 \%$ while $\delta^{18} \mathrm{O}$ varies $2.0 \%$ ( -14.1 to -12.1$)$ with a mean of $-13.0 \%$. Many of the perched springs fall below the GMWL, indicating that they have undergone some evaporation either during recharge in the soil zone or after discharging. The higher-elevation springs tend not to be evaporated (Ledge, Breen Creek at Ranch, Big Seep, and Lost Hammer springs, and Kawich Creek).

Figure 2-8 shows the major-ion chemistry of the perched springs in the Kawich and Cactus ranges. Springs range in total dissolved solids (TDS) from 100 to $580 \mathrm{mg} / \mathrm{L}$ with most springs over $300 \mathrm{mg} / \mathrm{L}$. Almost all springs, regardless of TDS, have proportionally more calcium than sodium (except Stinking Spring) and more bicarbonate than sulfate and chloride (except Horse Trough Spring). 


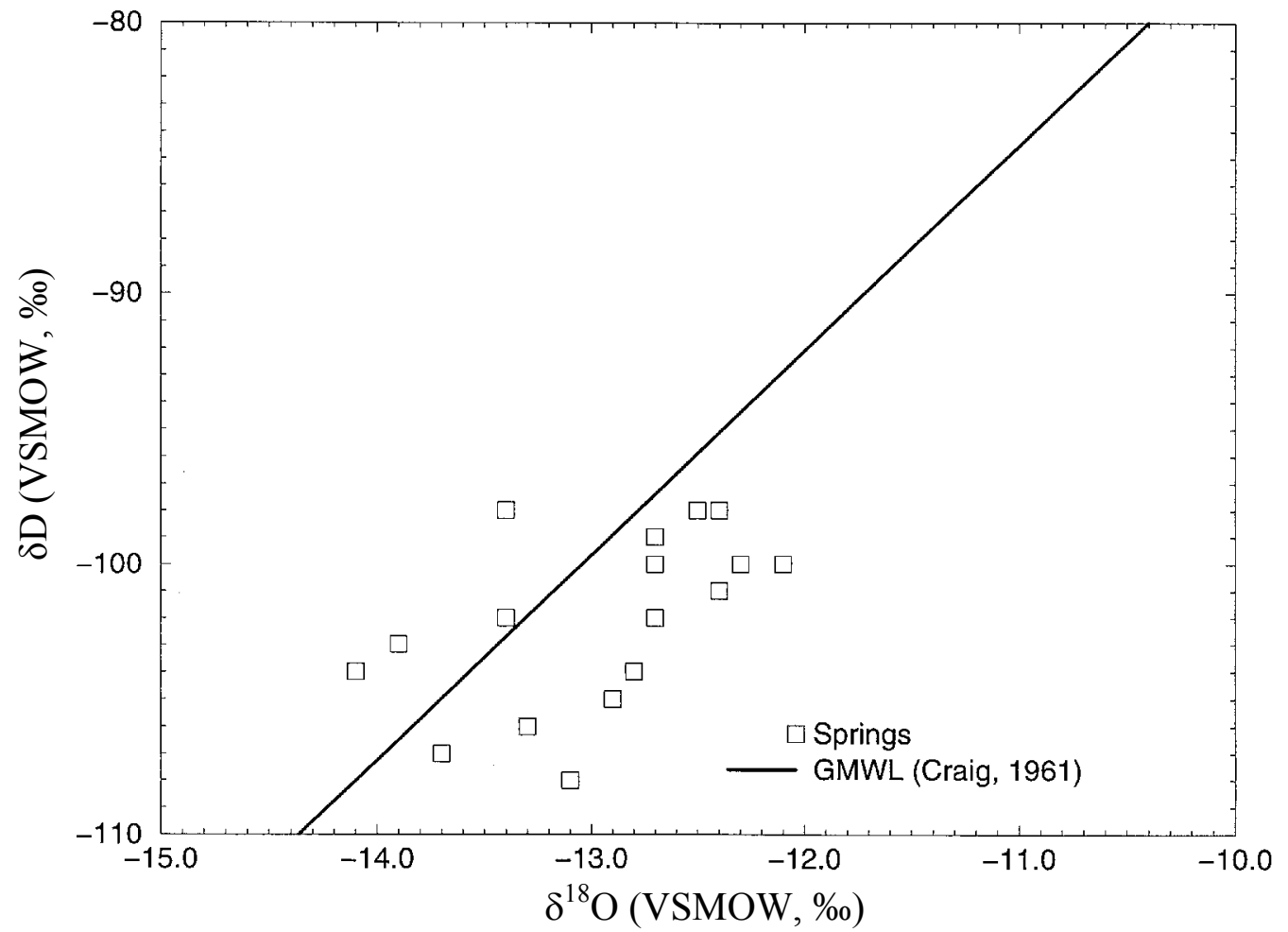

Figure 2-7. $\delta \mathrm{D}$ and $\delta^{18} \mathrm{O}$ of springs in the Kawich and Cactus ranges, Oasis Valley flow system.

Table 2-5. $\delta \mathrm{D}$ and $\delta^{18} \mathrm{O}$ of springs in the Kawich and Cactus ranges, Oasis Valley flow system.

\begin{tabular}{llllll}
\hline Spring & Mean $\delta \mathrm{D}$ & Mean $\delta^{18} \mathrm{O}$ & $\mathrm{n}$ & $\sigma \delta \mathrm{D}$ & $\sigma \delta^{18} \mathrm{O}$ \\
\hline Antelope & -100 & -12.7 & 1 & - & - \\
Cactus & -98 & -12.5 & 1 & - & - \\
Rose-Cactus Range & -102 & -12.7 & 1 & - & - \\
Rose-Kawich Range & -104 & -12.8 & 1 & - & - \\
Horse Trough & -100 & -12.3 & 1 & - & - \\
Sumner & -105 & -12.9 & 2 & 3 & 0.6 \\
Corral & -107 & -13.7 & 1 & - & - \\
Powder River & -100 & -12.1 & 1 & - & - \\
Georges Water & -98 & -12.4 & 1 & - & - \\
Silverbow & -108 & -13.1 & 1 & - & - \\
Stinking & -106 & -13.3 & 1 & - & - \\
Cedar & -101 & -12.4 & 1 & - & - \\
Breen Creek at Ranch & -102 & -13.4 & 1 & - & - \\
Eden Creek Ranch & -99 & -12.7 & 1 & - & - \\
Big Seep & -98 & -13.4 & 1 & - & - \\
Lost Hammer & -103 & -13.9 & 1 & - & - \\
Ledge & -104 & -14.1 & 11 & 1 & 0.1 \\
Kawich Creek & -103 & -13.9 & 29 & 2 & 0.2 \\
\hline
\end{tabular}




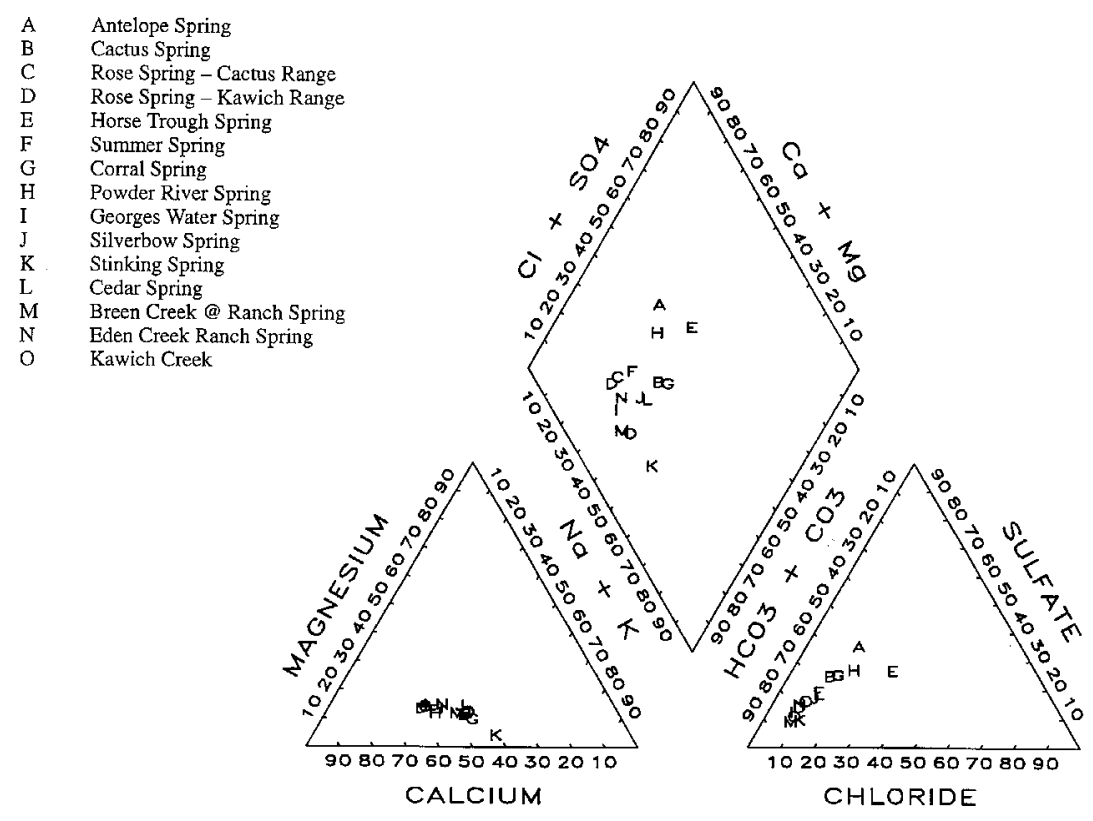

Figure 2-8. Major-ion chemistry of springs in the Kawich and Cactus ranges in the northern Oasis Valley flow system.

\subsubsection{Pahute Mesa and Timber Mountain}

Pahute Mesa, assumed to be one of the major recharge areas in the Oasis Valley flow system, does not have any spring discharge. The lack of springs is the result of the relatively flat mesa topography and the thick sequence of porous, highly fractured ash-flow and ash-fall tuffs and rhyolitic lava flows within the Silent Mountain caldera. However, perched groundwaters have been encountered in drill holes where less permeable zeolitized bedded tuff and nonwelded ash flow tuffs occur at depth (Blankennagel and Weir, 1973). These perched waters in Pahute Mesa have not been characterized chemically or isotopically. However, recent studies have attempted, unsuccessfully, to determine whether water encountered in large-diameter (up to $2.44 \mathrm{~m}$ ) boreholes was perched groundwater, drilling fluid draining back into the borehole from the geologic formation, or a combination of the two (Hershey and Brikowski, 1995; Brikowski, 1994; Brikowski et al., 1993; Gardner and Brikowski, 1993). Timber Mountain also does not have any spring discharge and few drill holes characterizing the geology. Timber Mountain lies in the center of the Timber Mountain caldera and, similar to Pahute Mesa, is composed of outcrops of ash-flow and ash-fall tuffs and rhyolitic lava flows (Frizzell and Shulters, 1990). Because of the lack of chemical and isotopic data for shallow/perched groundwater in Pahute Mesa and Timber Mountain, data from other volcanic rock areas of the NTS will be described including Rainier Mesa (east of Pahute Mesa), Shoshone Mountain (south of Pahute Mesa), and Fortymile Wash (south of Pahute Mesa). A total of $70 \delta \mathrm{D}$ and $\delta^{18} \mathrm{O}$ pairs from two spring orifices were periodically collected from Whiterock Spring from October 1981 through April 1987. Whiterock Spring discharges from the south-facing slope on the foothills of the Belted Range from zeolitic nonbedded tuff, just east of Rainier Mesa. Two $\delta \mathrm{D}$ and $\delta^{18} \mathrm{O}$ pairs are available for Topopah Spring, which lies on the southern flank of Shoshone Mountain and issues from bedded tuff. Samples of seepage into two Rainier Mesa tunnels were collected from July 1984 through August 1986. Forty-two samples were collected from U12n.03 Tunnel and 36 
samples were collected from U12n.05 Tunnel. A shallow groundwater sample was collected from UE-29a\#1 and UE-29a\#2 in Fortymile Wash in November 1997. Both wells are completed in bedded tuff and have the same isotopic values. Table 2-6 and Figure 2-9 show mean $\delta \mathrm{D}$ and $\delta^{18} \mathrm{O}$ for the two springs, the tunnel seepage, and the two wells. Except for Whiterock Spring, the mean values fall on or above the GMWL, indicating that most shallow/perched groundwater has not evaporated during recharge in the soil zone or after discharge. $\delta \mathrm{D}$ for the NTS shallow/perched groundwater ranges from -101 to $-88 \%$ with a mean of $-94 \%$ and $\delta^{18} \mathrm{O}$ from -14.2 to $-11.0 \%$ with a mean of $-12.6 \%$. These isotopic values for the NTS are $9 \delta \mathrm{D}$ and $0.4 \%$ $\delta^{18} \mathrm{O}$ heavier than the mean values of springs in the Kawich and Cactus ranges.

Table 2-6. $\quad \delta \mathrm{D}$ and $\delta^{18} \mathrm{O}$ of Topopah and Whiterock springs, Raniner Mesa Tunnels U12n.03 and U12n.05, and wells UE-29a\#1 and UE-29a\#2.

\begin{tabular}{lccccccccc}
\hline Location & & $\delta \mathrm{D}$ & $\delta \mathrm{D}$ & $\delta \mathrm{D}$ & & $\delta^{18} \mathrm{O}$ & $\delta^{18} \mathrm{O}$ & $\delta^{18} \mathrm{O}$ & \\
\hline Topopah Spring & 2 & -94 & -88 & -91 & 4 & -11.7 & -11.0 & -11.5 & 0.4 \\
Whiterock Spring & 70 & -98 & -89 & -95 & 2 & -13.9 & -11.4 & -12.4 & 0.4 \\
U12n.03 Tunnel & 43 & -101 & -92 & -98 & 2 & -14.2 & -12.4 & -13.5 & 0.3 \\
U12n.05 Tunnel & 37 & -97 & -90 & -94 & 2 & -13.3 & -11.9 & -12.9 & 0.2 \\
UE-29a\#1 & 1 & - & - & -91 & - & - & - & -12.6 & - \\
UE-29a\#2 & 1 & - & - & -91 & - & - & - & -12.6 & - \\
\hline
\end{tabular}

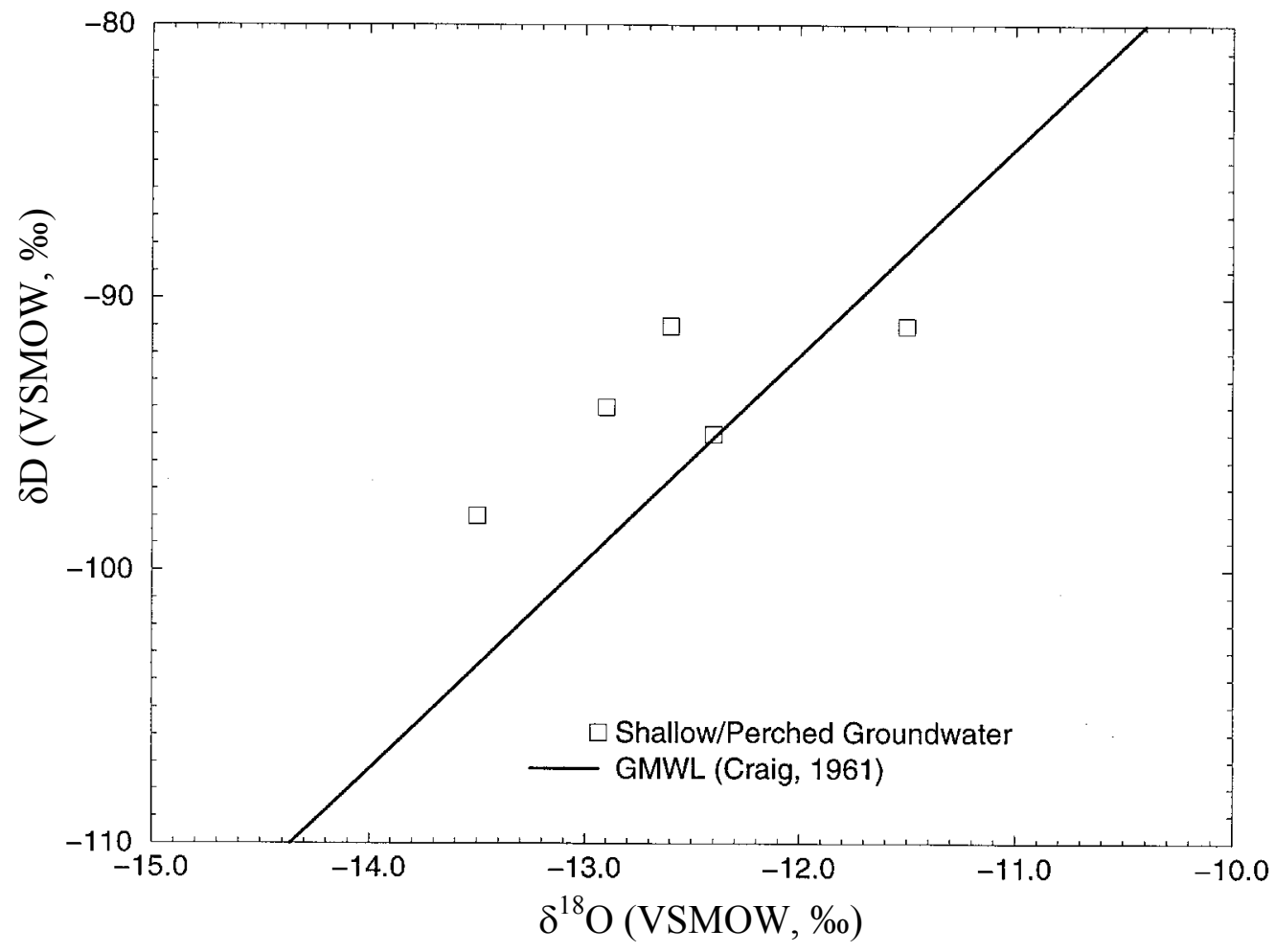

Figure 2-9. Mean $\delta \mathrm{D}$ and $\delta^{18} \mathrm{O}$ of NTS shallow/perched groundwater. 
Figure 2-10 shows the major-ion chemistry of Topopah Spring, Whiterock Spring, U12n.03 Tunnel, U12n.05 Tunnel, UE-29a\#1, and UE-29a\#2. Shallow/perched groundwater at the NTS ranges in TDS from 113 to $347 \mathrm{mg} / \mathrm{L}$. All shallow/perched groundwater has proportionally more sodium than calcium and more bicarbonate than sulfate and chloride.

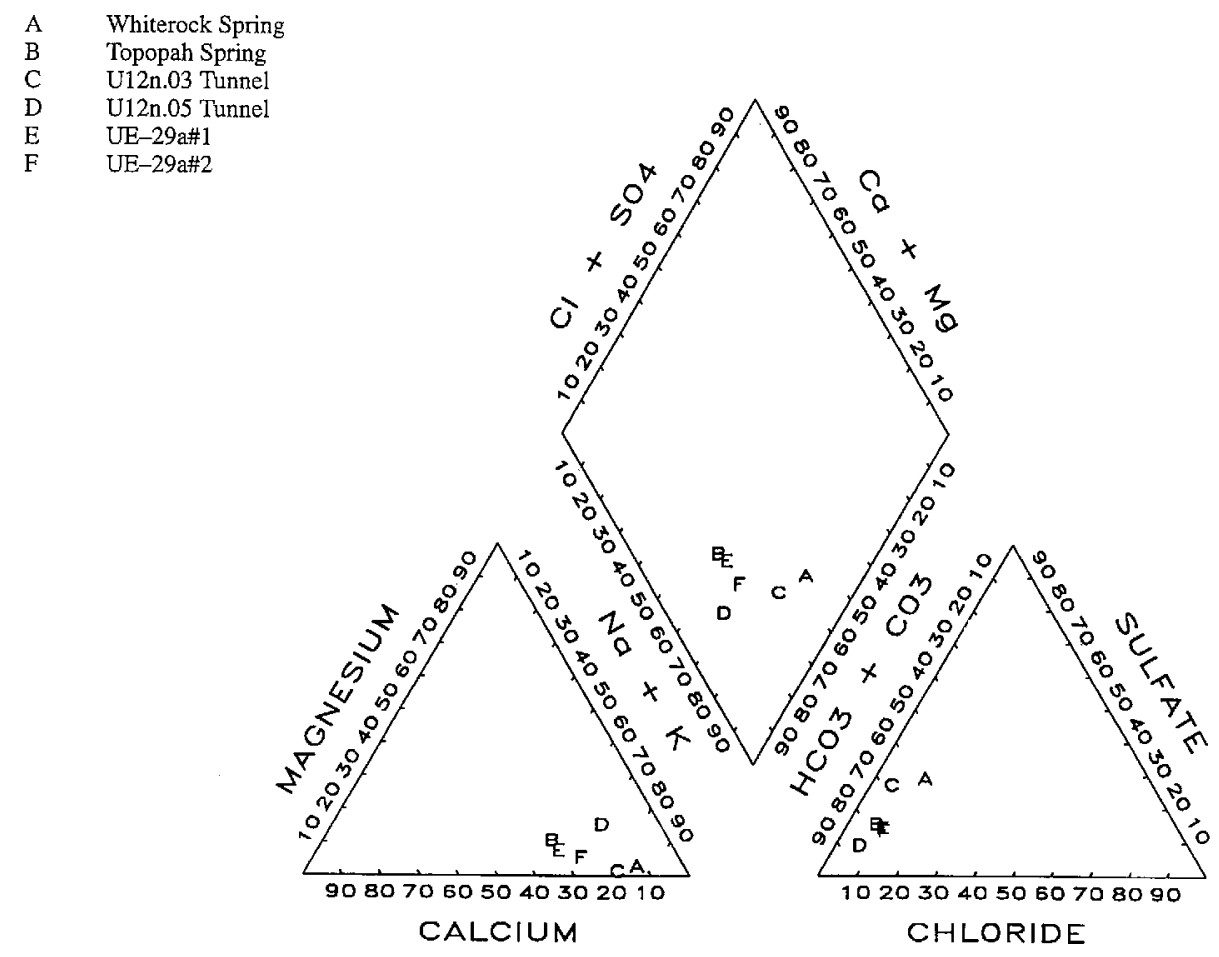

Figure 2-10. Major-ion chemistry of shallow/perched groundwater at the NTS.

\subsection{Discussion}

Having presented the isotopic and chemical character of precipitation and shallow/perched groundwater in the Kawich Range, Cactus Range, and the NTS above, the relationship of precipitation to shallow/perched groundwater and then shallow/perched groundwater to deeper groundwater will be examined.

\subsubsection{Kawich and Cactus Ranges Recharge}

Figure 2-11 shows $\delta \mathrm{D}$ and $\delta^{18} \mathrm{O}$ pairs of precipitation and spring discharge, the total precipitation-weighted isotopic mean, and the seasonal precipitation-weighted isotopic means for the Kawich and Cactus ranges. The figure shows spring discharge plotting in a tight group relative to the wide spread of the precipitation, demonstrating the homogenization of the precipitation isotopic signature by the recharge process. The spring discharge also plots very close to the total precipitation-weighted isotopic mean. However, as shown in Figure 2-7, the spring discharge has undergone a small amount of evaporation and the cool-season precipitationweighted isotopic mean may be more representative of the isotopic signature of the recharging water. Winograd et al. (1998) demonstrated that cool-season precipitation is the predominant recharge source in the nearby Spring Mountains in southern Nevada. Also, Ingraham et al. (1991) concluded that both winter and summer precipitation events contributed to spring discharge in the NTS area, but that summer recharge occurred only as a result of exceptionally 
large precipitation events. Additionally, pmc data for Silverbow Spring (111 pmc), Sumner Spring (79 pmc), and Rose Spring-Kawich Range (67 pmc) from Rose et al. (1997) show that several springs in the Kawich Range have young groundwater discharge. Therefore, discharge from the perched springs in the Kawich and Cactus ranges appears to be derived from recent precipitation and the mean $\delta \mathrm{D}$ and $\delta^{18} \mathrm{O}$ of the springs should represent recent recharge in the northern portion of the Oasis Valley flow system. The mean $\delta \mathrm{D}$ and $\delta^{18} \mathrm{O}$ for springs in the Kawich and Cactus ranges is -103 and $-13.0 \%$, respectively.

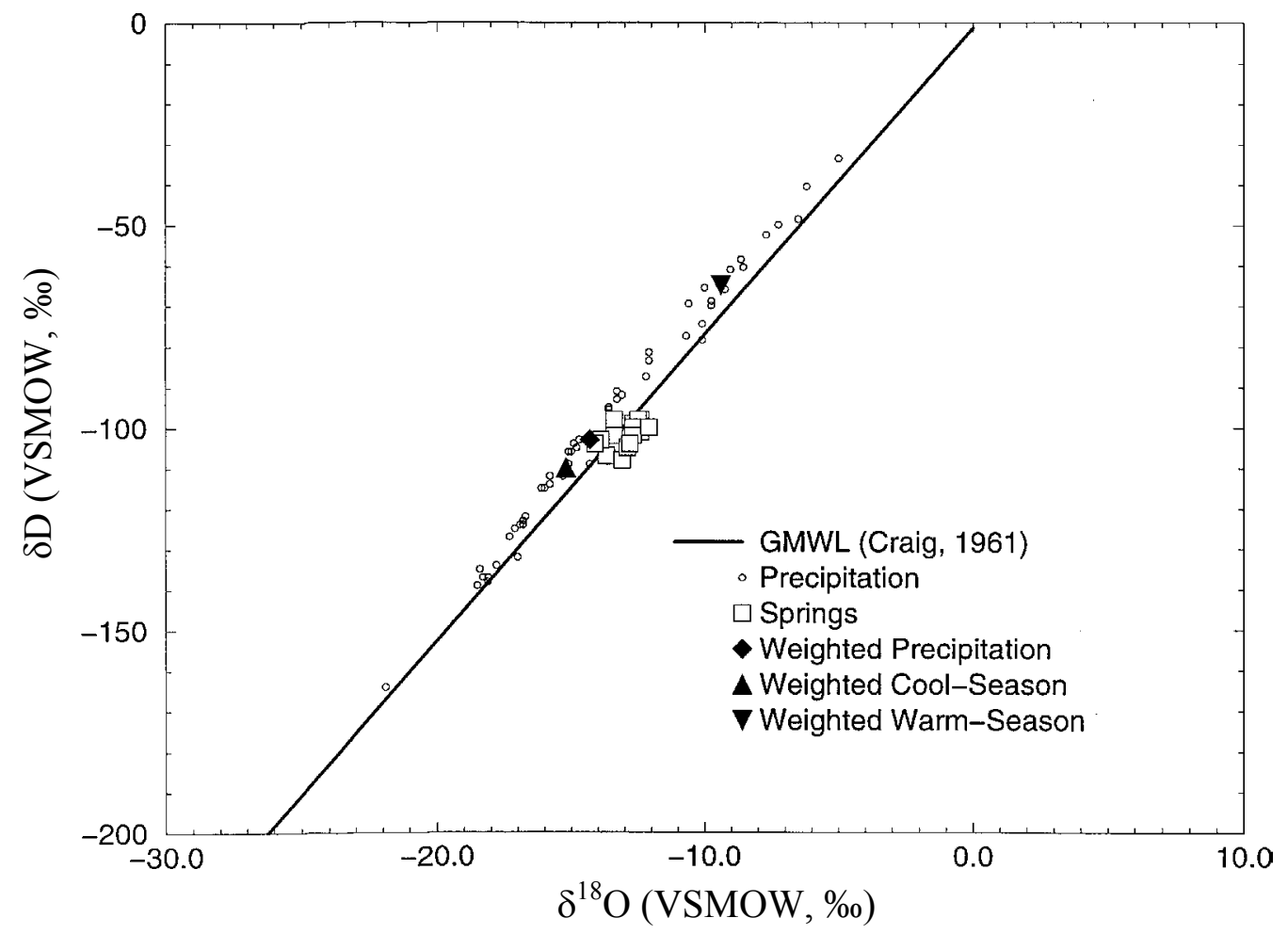

Figure 2-11. $\delta \mathrm{D}$ and $\delta^{18} \mathrm{O}$ of precipitation and spring discharge in the Kawich and Cactus ranges.

\subsubsection{Pahute Mesa Recharge}

Because Pahute Mesa's shallow/perched groundwater has not been sampled and characterized, this section describes other shallow/perched groundwater at the NTS that should be representative of Pahute Mesa shallow/perched groundwater. Figure 2-12 shows $\delta \mathrm{D}$ and $\delta^{18} \mathrm{O}$ pairs of precipitation, spring discharge, Rainier Mesa tunnel seepage, and shallow groundwater from Fortymile Wash; the total precipitation-weighted isotopic mean; and the seasonal precipitation-weighted isotopic means for the NTS. Similar to Figure 2-11 for the Kawich and Cactus ranges, Figure 2-12 shows shallow/perched groundwater at the NTS plotting in a tight group relative to precipitation and only slightly heavier than the cool-season precipitationweighted isotopic mean. The shallow/perched groundwater is heavier than the total precipitationweighted isotopic mean, again demonstrating that groundwater recharge at the NTS is predominantly cool-season precipitation. Tritium analyses from Lyles et al. (1990) show Whiterock Spring (19 to $80 \mathrm{pCi} / \mathrm{L}$ ) and Topopah Spring (64 to $83 \mathrm{pCi} / \mathrm{L}$ ) discharge is recent recharge derived from modern-day precipitation as do tritium values from Appendix B for UE$29 \mathrm{a} \# 1$ (43 pCi/L) and UE-29a\#2 (39 pCi/L). For further discussion, the mean $\delta \mathrm{D}$ and $\delta^{18} \mathrm{O}$ of 
shallow/perched groundwater at the NTS will be used to represent recharge at Pahute Mesa. The mean $\delta \mathrm{D}$ and $\delta^{18} \mathrm{O}$ for shallow/perched groundwater at the NTS is -94 and $-11.0 \%$, respectively.

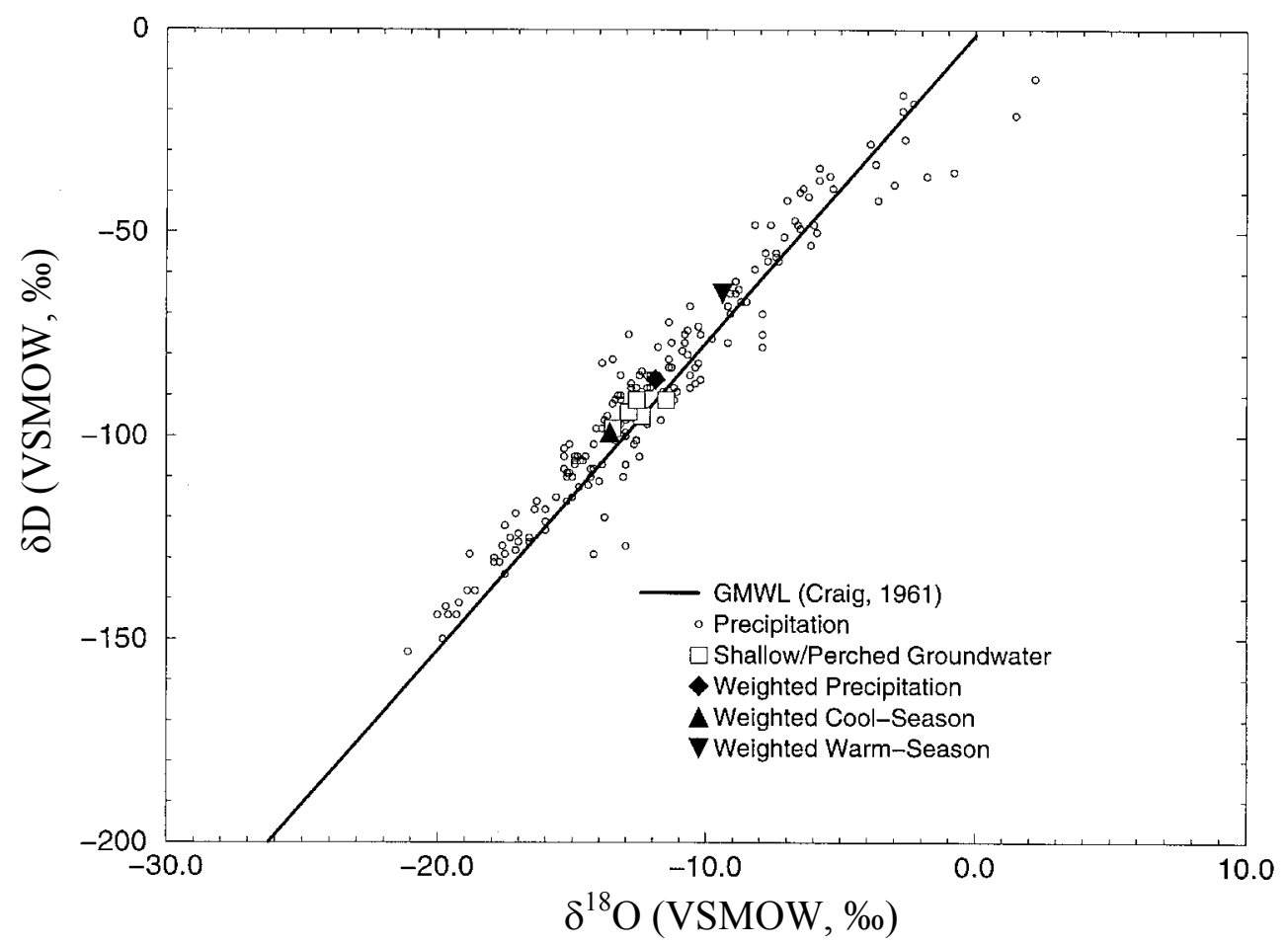

Figure 2-12. $\delta \mathrm{D}$ and $\delta^{18} \mathrm{O}$ of precipitation and shallow/perched groundwater at the NTS.

\subsubsection{Comparison of Recent Recharge to Groundwater}

\subsubsection{1 $\delta D$ and $\delta^{18} O$}

$\delta \mathrm{D}$ and $\delta^{18} \mathrm{O}$ for recent recharge, deep Pahute Mesa groundwater, and groundwater in Oasis Valley are shown on Figure 2-13. Oasis Valley groundwater, the discharge area for the flow system, has two components: an isotopically light component in the central portion of the valley and a heavier component on the western and eastern sides of the valley. For a more detailed discussion of the Oasis Valley isotopic signature see Chapter 3. Deep Pahute Mesa groundwater and central Oasis Valley groundwater are isotopically very similar, with the mean $\delta \mathrm{D}$ and $\delta^{18} \mathrm{O}$ only slightly lighter for Pahute Mesa (Pahute Mesa $=-112 \% 0 \delta,-14.8 \% 0 \delta^{18} \mathrm{O}$; central Oasis Valley $=-111 \% \circ \delta \mathrm{D},-14.7 \% 0 \delta^{18} \mathrm{O}$ ). The mean $\delta \mathrm{D}$ and $\delta^{18} \mathrm{O}$ for recent recharge from Pahute Mesa and the Kawich and Cactus ranges are isotopically much heavier than deep Pahute Mesa groundwater and Oasis Valley groundwater, indicating that recent recharge is not the source of these groundwaters. The isotopically light signature of groundwaters suggest that they may be older than recent recharge, originating from a colder climatic period when the precipitation was isotopically lighter than present day. Pahute Mesa has the oldest groundwater with very low ${ }^{14} \mathrm{C}$ content (UE-19c Water Well 8.0 pmc, U-20 Water Well 8.6 pmc, UE-19h 9.4 pmc). Central Oasis Valley groundwater is a little higher in ${ }^{14} \mathrm{C}$ (e.g., ER-OV-2 $16.2 \mathrm{pmc}$, Mullen Spring 18.2 pmc, ER-OV-3a3 $16.5 \mathrm{pmc}$ ). The slightly heavier isotopic signature and higher ${ }^{14} \mathrm{C}$ content in central Oasis Valley groundwater relative to Pahute Mesa suggest that Oasis Valley groundwater is derived from Pahute Mesa groundwater with a very small component of recent recharge shifting the isotopic signature heavier and adding some ${ }^{14} \mathrm{C}$. Another possible scenario is that 
some of the Oasis Valley groundwater may originate from the north with a small component of recent recharge, but deep groundwater data north from Cactus and Gold flats are not available. For a more detailed discussion of the possible sources of Oasis Valley groundwater see Chapter 4.

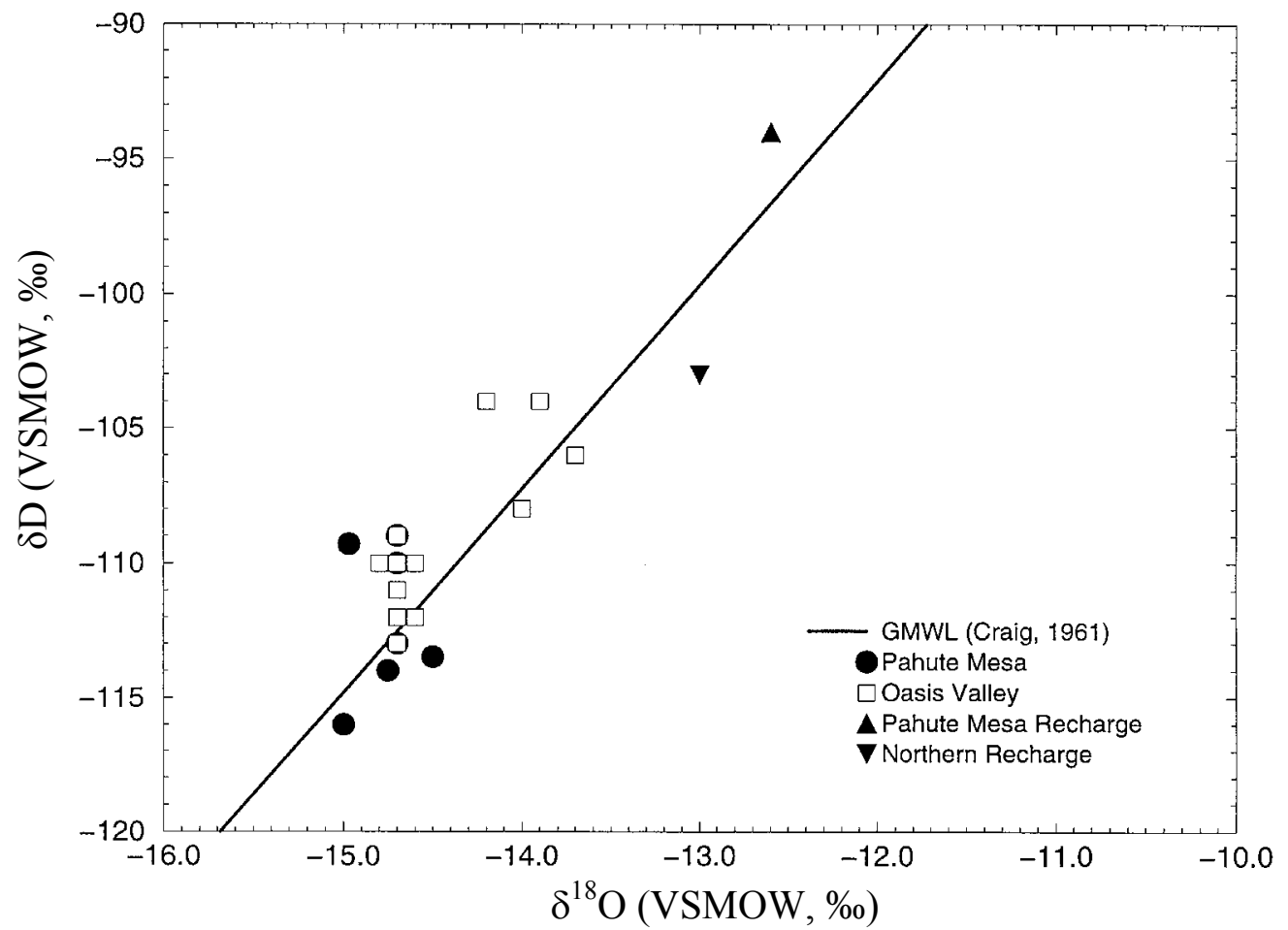

Figure 2-13. $\delta \mathrm{D}$ and $\delta^{18} \mathrm{O}$ of recent recharge and deep groundwater in the Oasis Valley flow system.

\subsubsection{Major-ion Chemistry}

Figure 2-14 shows the major-ion chemistry of recent recharge, deep Pahute Mesa groundwater, and Oasis Valley groundwater. As presented above, recharge waters in the Kawich and Cactus ranges have proportionally more calcium than sodium and more bicarbonate than chloride and sulfate, while NTS recharge waters have mostly sodium and bicarbonate. Oasis Valley groundwater is higher in sodium and sulfate than the recharge waters and Pahute Mesa groundwater. The sodium concentrations in groundwater of the Oasis Valley flow system increase because of continued volcanic rock dissolution along the flowpath from Pahute Mesa. Sulfate concentrations increase as groundwater moves through hydrothermally altered rock in western Pahute Mesa (Schoff and Moore, 1964; Winograd and Thordarson, 1975) and northeastern Oasis Valley (R. Warren, Los Alamos National Laboratory, personal communication, 1999). Deep Pahute Mesa groundwaters range in composition from low sulfate in eastern Pahute Mesa to higher sulfate in western Pahute Mesa, while sodium is always greater than calcium. For a more detailed discussion of major-ion chemistry see Chapter 1. 


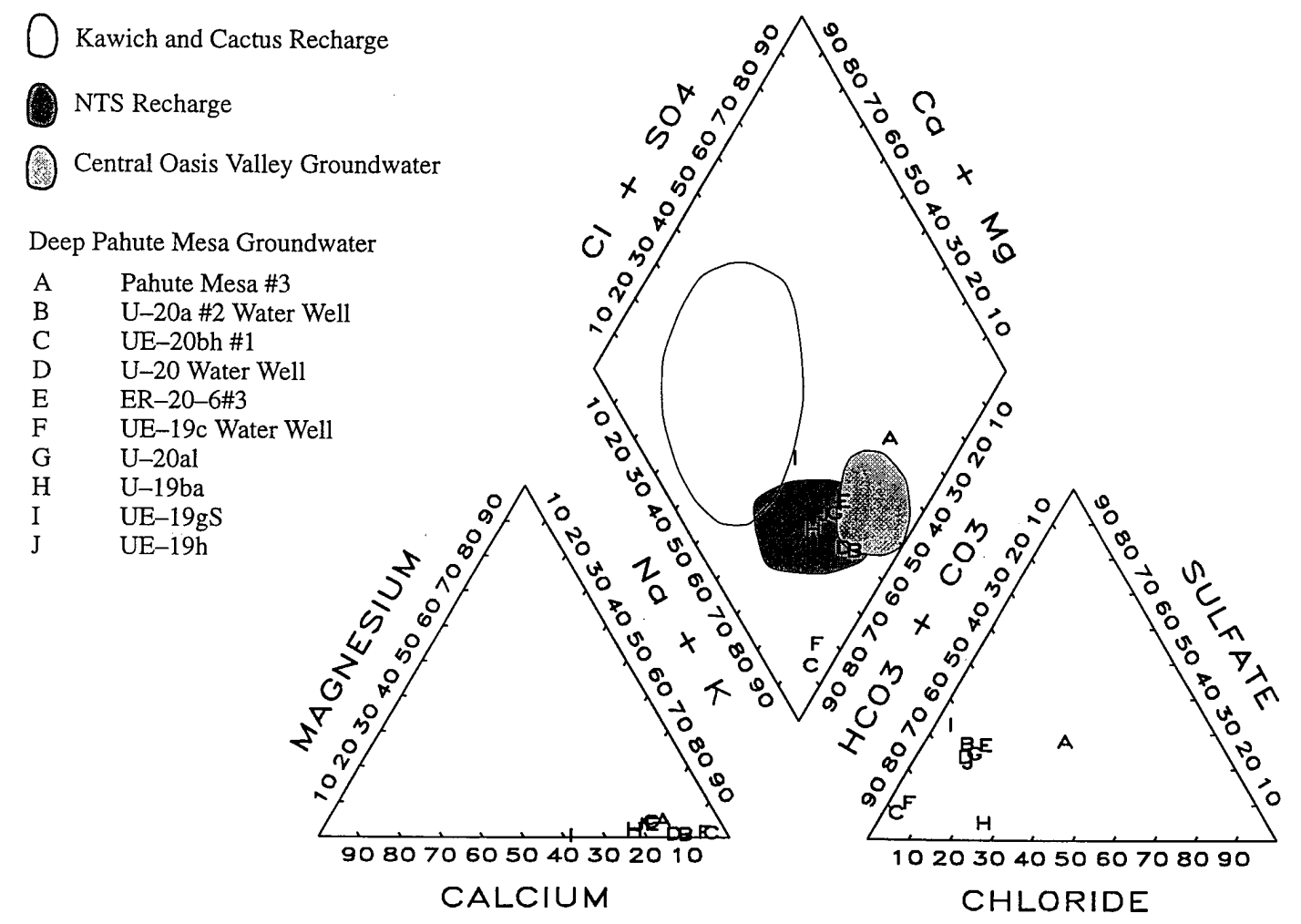

Figure 2-14. Major-ion chemistry or recent recharge, deep Pahute Mesa groundwater and central Oasis Valley groundwater.

\subsection{Summary}

The Oasis Valley flow system is of particular importance because of the potential movement of radionuclides through the system from the NTS, principally from the Pahute Mesa underground nuclear testing area, to springs and wells in Oasis Valley. To help interpret the movement of groundwater in the flow system using aqueous geochemistry and environmental isotopes, the nature of the groundwater recharge end members were characterized. This report summarizes new and historical chemical and isotopic data of both precipitation and groundwater and identifies the groundwater recharge inputs to the flow system.

Precipitation sample locations included four on Pahute Mesa, three on Rainier Mesa, one on Timber Mountain, two on Shoshone Mountain, and two on the Kawich Range. Samples were collected from 10/27/1981 to 12/12/1994 and the total precipitation-weighted isotopic means are $7 \%$ lighter for $\delta \mathrm{D}$ and $0.8 \%$ lighter for $\delta^{18} \mathrm{O}$ than the arithmetic isotopic means, demonstrating the larger contribution of isotopically lighter winter precipitation relative to the heavier summer. The total precipitation-weighted isotopic means are poorly correlated with elevation.

Perched springs in the Kawich and Cactus ranges have undergone some evaporation during recharge in the soil zone or after discharging; however, higher elevation springs tend not to be evaporated. Most springs have proportionally more calcium than sodium and more bicarbonate than sulfate and chloride reflecting the dissolution of both volcanic and carbonate rocks. Pahute Mesa shallow/perched groundwaters are poorly characterized, so other NTS shallow/perched groundwaters were used as surrogates. Most shallow/perched NTS groundwaters have not been 
evaporated during either recharge or discharge. The mean shallow/perched NTS groundwaters are $9 \%$ o $\delta$ and $0.4 \%$ o $\delta^{18} \mathrm{O}$ heavier than the mean values of the Kawich and Cactus ranges. NTS shallow/perched groundwaters have proportionally more sodium than calcium and more bicarbonate than sulfate and chloride. Cool-season precipitation is the predominant source of recharge to springs in the Kawich and Cactus ranges and to shallow/perched NTS groundwater as shown by the cool-season precipitation-weighted means. ${ }^{14} \mathrm{C}$ and tritium activity show that springs in the Kawich and Cactus ranges and shallow/perched NTS groundwater are recent recharge.

Comparison of isotopic values of recent recharge, deep Pahute Mesa groundwater, and Oasis Valley groundwater show that deep Pahute Mesa and Oasis Valley groundwaters originated during a cooler climatic period. The heavier isotopic signature and higher ${ }^{14} \mathrm{C}$ content in the central Oasis Valley are derived from Pahute Mesa groundwater with a small proportion of recent recharge. Pahute Mesa groundwaters evolve from a sodium-bicarbonate water to a sodium-sulfate water as they flow from Pahute Mesa to Oasis Valley. 


\section{CHAPTER 3 \\ GROUNDWATER GEOCHEMISTRY - ANALYTICAL RESULTS AND INTERPRETATIONS}

\subsection{Introduction}

This chapter summarizes the results of chemical and isotopic measurements of groundwater samples from the Pahute Mesa-Oasis Valley flow system. The objective is to characterize and interpret the geochemistry of groundwater occurring along flowpaths extending from the underground nuclear testing area in western Pahute Mesa to the groundwater discharge zone in Oasis Valley, north of Beatty, Nevada. In November 1997, samples were acquired specifically for this task, many of which were obtained from ER-OV wells developed for this project with funding from the UGTA project. The locations of these samples are shown in Figure 3-1.

The data reported in this chapter are subsequently used to develop and test geochemical modeling simulations of groundwater transport discussed in Chapter 4. These simulations provide a quantitative means of testing the conceptual models that are presented here.

This chapter includes three sections. The first section describes analytical methods. In the second section, the results are discussed and interpreted in the context of the Pahute Mesa-Oasis Valley flow system. The last section briefly summarizes the key findings from this work.

\subsection{Analytical Methods}

\subsubsection{Stable Isotopes of Hydrogen and Oxygen}

Stable isotope samples were collected in glass bottles with airtight caps to prevent leakage or evaporation. Samples were prepared for hydrogen isotope analysis by the quantitative conversion of water to hydrogen gas using uranium as a reducing agent (Bigeleisen et al., 1952). Oxygen isotope analyses were performed by the complete conversion of water to carbon dioxide using guanidine hydrochloride (Dugan et al., 1985). Stable isotope ratios were measured on an isotope ratio mass spectrometer at DRI. Results are reported in the standard delta $(\delta)$ notation as permil (\%) deviations from the Standard Mean Ocean Water (SMOW) reference standard. The reproducibility of the $\delta \mathrm{D}$ and $\delta^{18} \mathrm{O}$ values is $\pm 1 \%$ and $\pm 0.2 \%$, respectively.

\subsubsection{Carbon Isotopes}

Dissolved inorganic carbon (DIC) samples were collected in 125-ml glass bottles with air-tight septa caps to prevent atmospheric exchange. Samples were treated with a few drops of saturated $\mathrm{HgCl}_{2}$ in the field to prevent biological degradation, and were stored refrigerated. DIC was extracted by acidifying the sample with 100 percent $\mathrm{H}_{3} \mathrm{PO}_{4}$ under vacuum and cryogenically trapping the evolved $\mathrm{CO}_{2}$ gas (McNichol et al., 1994). The $\mathrm{CO}_{2}$ sample was then split, and half was analyzed for ${ }^{14} \mathrm{C}$ while the other half was used to determine the ${ }^{13} \mathrm{C} /{ }^{12} \mathrm{C}$ stable isotope ratio. Stable isotope ratios were measured on a VG Prism isotope ratio mass spectrometer at LLNL. Results are reported in the conventional $\delta$ notation as \%o deviations from the Pee Dee Belemnite (PDB) reference standard. The analytical precision in $\delta^{13} \mathrm{C}$ values is $\pm 0.3 \%$. Sample splits for ${ }^{14} \mathrm{C}$ analysis were reduced to graphite by reaction with hydrogen gas at $570^{\circ} \mathrm{C}$ in the presence of a cobalt metal catalyst and analyzed by accelerator mass spectrometry at LLNL (Vogel et al., 1987). Results are reported as pmc, which represents the ${ }^{14} \mathrm{C} /{ }^{12} \mathrm{C}$ ratio of the sample normalized to the ratio of 1950 atmospheric $\mathrm{CO}_{2}$ (Stuiver and Polach, 1977). Radiocarbon ages are reported assuming a half-life of 5,730 years (Walker et al., 1989). Analytical precision is \pm 1 pmc. 
Figure 3-1. Location of groundwater sampling locations used in this investigation. 


\section{$\underline{3.2 .3 \text { Tritium }}$}

Tritium samples were collected in 500-ml glass bottles with air-tight caps designed to prevent atmospheric exchange. Tritium was analyzed by the helium-accumulation method (Surano et al., 1992) wherein water samples are cryogenically degassed, sealed, and stored for 60 days to allow the accumulation of ${ }^{3} \mathrm{He}$ from tritium decay. The sample was subsequently degassed, and the ${ }^{3} \mathrm{He}$ was isolated and measured on a VG-5400 mass spectrometer at LLNL. Results are reported in tritium units (TU) where one TU $=$ one ${ }^{3} \mathrm{H}$ atom in $10^{18}$ hydrogen $\left({ }^{1} \mathrm{H}\right)$ atoms. The analytical precision for this method is $\pm 0.5 \mathrm{TU}$ Tritium concentrations are also reported in $\mathrm{pCi} / \mathrm{L}$, where $1 \mathrm{TU}=3.2 \mathrm{pCi} / \mathrm{L}$.

\section{$\underline{3.2 .4 \text { Helium Isotopes }}$}

Noble gas samples were collected in 3/8" copper tubes with pinch clamp assemblies that seal the water sample free of gas bubbles. In the laboratory, the copper tubes were vacuum fitted to an evacuated container, the water sample was released and degassed, and all gases except helium and neon were condensed into a cold trap at $24 \mathrm{~K}$. Helium was separated from neon by use of a cryogenic cold trap filled with charcoal. Helium was then transferred to a VG-5400 mass spectrometer where ${ }^{4} \mathrm{He}$ and ${ }^{3} \mathrm{He}$ were measured by a Faraday Cup and Johnston-MM1 electron multiplier, respectively. Measurement calibration was achieved by comparison with air standards. Analytical precision is $\pm 2 \%$ for ${ }^{4} \mathrm{He}$ concentrations and $\pm 2 \%$ for ${ }^{3} \mathrm{He} /{ }^{4} \mathrm{He}$ ratios.

\section{$\underline{3.2 .5 \text { Chlorofluorocarbons }}$}

Water samples for analysis of chlorofluorocarbons (CFCs) were collected with submersible pumps using specialized sampling equipment that isolates water samples from atmospheric gases. This sampling equipment is continually flushed with ultra-pure nitrogen gas, so a water sample is only in contact with CFC-free nitrogen gas. As a further precaution against atmospheric contamination, a CFC scrubber is placed in-line between the ultra-pure nitrogen tank and the CFC sampling apparatus. After purging the sampling apparatus and borosilicateglass sample vials with ultra-pure nitrogen gas and sample water, samples were collected by sealing the vials with an oxy-acetylene torch. Samples were analyzed by using a purge-and-trap gas chromatography procedure with an electron capture detector. Busenberg and Plummer (1992) give details of the sampling and analytical methods. This method has a detection limit of 1.0 picogram per kilogram ( $\mathrm{pg} / \mathrm{kg}$ ). Analytical uncertainty for CFC analyses is $\pm 3 \%$ for concentrations $>50 \mathrm{pg} / \mathrm{kg}$, increasing to $\pm 50 \%$ at the detection limit of $1 \mathrm{pg} / \mathrm{kg}$.

\subsubsection{Trace Element Chemistry}

Trace element samples were filtered to $0.45 \mu \mathrm{m}$, and stored in acid-washed, high-density polyethylene bottles. Samples were acidified on site to $\mathrm{pH}<2$ using ultra-pure $\mathrm{HNO}_{3}$. Trace element concentrations were determined via inductively coupled plasma mass spectrometry (ICP-MS; Perkin-Elmer Elan 5000) with ultrasonic nebulization at the Harry Reid Center for Environmental Studies, University of Nevada, Las Vegas (Stetzenbach et al., 1994). A series of reference standards of known concentrations were used to calibrate the ICP-MS and to verify the measurements. Rare earth elements (REEs) are present in the samples at concentrations below the method detection limit, requiring pre-concentration prior to sample analysis. 


\subsubsection{Strontium and Uranium Isotopes}

Strontium (Sr) and uranium (U) isotope samples were filtered to 0.45 or $0.22 \mu \mathrm{m}$ in the field, and stored in low-density polyethylene, acid-cleaned 500-ml bottles. To determine strontium concentrations by isotope dilution, water samples were mixed with a spike solution containing a known amount of isotopically enriched ${ }^{84} \mathrm{Sr}$. After equilibration with the spike, strontium was then purified by conventional ion chromotography using cation exchange resin in an $\mathrm{HCl}$ medium. The purified $\mathrm{Sr}$ was loaded onto the evaporation side of a double rhenium filament, and the ${ }^{87} \mathrm{Sr} /{ }^{86} \mathrm{Sr}$ ratio was determined on a Finnigan MAT 262 thermal ionization mass spectrometer at the USGS in Denver. Two samples of the USGS marine carbonate standard EN1 were analyzed in each magazine of 13 filaments. Mass fractionation during isotopic analysis was eliminated by normalizing the measured ${ }^{87} \mathrm{Sr} /{ }^{86} \mathrm{Sr}$ ratios to a value of 0.1194 , and adjusting the ${ }^{87} \mathrm{Sr} r{ }^{86} \mathrm{Sr}$ ratios accordingly. The mass corrected ${ }^{87} \mathrm{Sr}{ }^{86} \mathrm{Sr}$ values were then adjusted to a scale on which the value from standard EN-1 is 0.70920 (the value of modern ocean water). Uncertainties in the normalized and adjusted ${ }^{87} \mathrm{Sr} /{ }^{86} \mathrm{Sr}$ ratios are better than $\pm 0.01 \%$ at the 95 percent confidence level. Strontium isotopic values are reported as \%o deviations from modern seawater in a manner analogous to that used to report stable isotope compositions (Peterman et al., 1992):

$$
\delta^{87} \mathrm{Sr}=\left[\frac{{ }^{87} \mathrm{Sr} /{ }^{86} \mathrm{Sr}}{0.70920}-1\right] \cdot 1000
$$

For uranium determinations, acid was added to the field-filtered water samples in the laboratory and the bottles were sonified to ensure that $\mathrm{U}$ remained in solution. Uranium concentrations were determined by isotope dilution using a spike solution containing known amounts of isotopically enriched ${ }^{236} \mathrm{U}$. Uranium was separated and purified using anionexchange chromatographic resins in $\mathrm{HCl}$ and $\mathrm{HNO}_{3}$ media. Between 139 and 4,840 nanograms (ng) of U were loaded onto the evaporation side of a double rhenium filament. Isotopic measurements of ${ }^{236} U /{ }^{235} \mathrm{U}$ and ${ }^{234} \mathrm{U} /{ }^{235} \mathrm{U}$ were determined on a Finnigan MAT 262 thermal ionization mass spectrometer equipped with an ion-counting secondary electron multiplier. Total procedural blanks are between 20 and $100 \mathrm{pg}$ of ${ }^{238} \mathrm{U}$. Abundances of ${ }^{234} \mathrm{U}$ in the blank are too low to be measured accurately. Therefore, the ${ }^{234} \mathrm{U} /{ }^{238} \mathrm{U}$ is assumed to be in secular equilibrium, yielding a ${ }^{234} \mathrm{U}$ blank of 0.0003 to $0.005 \mathrm{pg}$. Data are corrected for contributions from tracer solutions, chemistry blank, and mass fractionation, and are normalized to a constant ${ }^{234} \mathrm{U} /{ }^{238} \mathrm{U}$ value for NIST SRM 4321B uranium standard $\left({ }^{234} \mathrm{U} /{ }^{238} \mathrm{U}=5.29 \times 10^{-5}\right)$ using the values measured in each barrel of 13 filaments. Multiple analyses of a secular equilibrium standard analyzed using the same methods result in ${ }^{234} \mathrm{U} /{ }^{238} \mathrm{U}$ ratios that are within analytical error of unity. Decay constants for ${ }^{234} \mathrm{U}$ and ${ }^{238} \mathrm{U}$ are $2.833 \times 10^{-6} \mathrm{yr}^{-1}$ and $1.55124 \times 10^{-10} \mathrm{yr}^{-1}$, respectively. Uncertainties are propagated at the 95 percent confidence level.

\subsection{Results}

\subsubsection{Stable Isotopes of Hydrogen and Oxygen}

The stable isotope ratios of hydrogen $\left({ }^{2} \mathrm{H} /{ }^{1} \mathrm{H}\right.$ or $\left.\mathrm{D} / \mathrm{H}\right)$ and oxygen $\left({ }^{18} \mathrm{O} /{ }^{16} \mathrm{O}\right)$ show systematic variations in hydrologic systems that can be used to trace the origin and transport pathways of different water masses. The $\delta^{18} \mathrm{O}$ and $\delta \mathrm{D}$ values of precipitation are strongly dependent on temperature, and vary with latitude, elevation, and distance from the ocean (Dansgaard, 1964). Once the precipitation has infiltrated the saturated groundwater zone, the 
stable isotope values are generally conservative. If the groundwater isotope content does not change along the flowpath, it will reflect the origin of the water. Conversely, if the groundwater isotope content does change along the flowpath, it will reflect the history of the water (e.g., mixing of different water masses) (Fontes, 1980).

Figure 3-2 ( $\delta \mathrm{D}$ and $\delta^{18} \mathrm{O}$ values for wells and springs in the Oasis Valley flow system. located in back of this report) is a map of southern Nye County, including the NTS, Oasis Valley, and Tonopah Test Range, showing the $\delta \mathrm{D}$ values for selected springs and wells in this region and is located at the back of this report. Data are tabulated in Appendix B. Groundwater in Oasis Valley has $\delta \mathrm{D}$ values ranging from -104\%o (Coffers Windmill) to -113\%o (ER-OV-6a). A narrower range in $\delta \mathrm{D}$ values (-109 to $-113 \%$ ) is observed for samples from the central discharge area in Oasis Valley. These values overlap that of U-20 Water Well (U-20 WW) on Pahute Mesa (-113\%o), and are similar to historical $\delta D$ values for Pahute Mesa groundwater (109 to $-115 \%$, with the exception of Water Well $8(\mathrm{WW}-8)$, where $\delta \mathrm{D}=-103 \%$ ). These results imply a direct groundwater flowpath from western Pahute Mesa to Oasis Valley. Groundwater from WW-8 and the UE-29a wells is isotopically heavier (less negative) in $\delta \mathrm{D}$ as compared to wells on Pahute Mesa or in Oasis Valley. The groundwater from these wells probably reflects a large component of local groundwater recharge. The weighted average $\delta^{18} \mathrm{O}$ value for precipitation from Pahute Mesa is approximately -13.2\%o (Ingraham et al., 1991), which corresponds to a mean $\delta \mathrm{D}$ value of around $-96 \%$. Water from borehole WW-8 has a $\delta \mathrm{D}$ value ($103 \%$ ) that is slightly lighter (more negative) than local precipitation, and may represent a mixture of local recharge with regional flow beneath Pahute Mesa. Similar arguments for a local recharge component can be made for the groundwater from Coffers Windmill $(\delta \mathrm{D}=-104 \%)$, and other wells in the Fortymile Wash area (e.g., J-13 and ER-30-1, with $\delta$ D values of -98 and 91\%, respectively).

In the northwestern part of Oasis Valley (represented by ER-OV-5 and Springdale Well), groundwater $\delta \mathrm{D}$ values are isotopically heavier (-104 to $-106 \%$ o) than springs and wells from the central Oasis Valley discharge area (-109 to $-112 \%$ ). The groundwater in northwestern Oasis Valley is inferred to have a recharge component from the north or northwest, as represented by a sample from Tolicha Peak well $(\delta D=-101 \%)$. Further to the north, small springs in the Cactus and Kawich ranges have $\delta \mathrm{D}$ values between -98 and $-108 \%$ (see Figure 3-2). Note that modern local recharge in these areas does not account for the groundwater isotopic values beneath Pahute Mesa or in the central Oasis Valley discharge area. Conversely, groundwater from alluvial aquifers on the Tonopah Test Range in some cases has very light $\delta \mathrm{D}$ values (as low as $-129 \%$ at Roller Coaster Well). This groundwater was previously interpreted to represent recharge during the last ice age, when cooler climates prevailed in this region (Davisson et al., 1999).

The origin of regional groundwater flow beneath Pahute Mesa and into Oasis Valley remains unresolved. Blankennagel and Weir (1973) estimated a groundwater influx of $\sim 5,500$ acre-feet/year into Pahute Mesa from the north, via Gold Flat and/or Kawich Valley. Isotopic evidence for a regional influx of low $\delta \mathrm{D}$ water into Pahute Mesa is unavailable due to a lack of appropriate well sites north of the mesa. However, regional groundwater flow in Nevada is known to follow deep interbasin flowpaths through laterally extensive aquifer systems (Winograd and Thordarson, 1975; Mifflin and Hess, 1979; Thomas et al., 1996; Davisson et al., 1999). It is therefore plausible that the groundwater beneath Pahute Mesa is part of a much larger 
regional flow system, driven by hydraulic gradients that are laterally continuous over a broad region (Harrill et al., 1988).

A plot of $\delta \mathrm{D}$ versus $\delta^{18} \mathrm{O}$ values (Figure 3-3) for groundwater from the Pahute Mesa-Oasis Valley region is useful for interpreting the relative contributions from local versus regional sources. The GMWL is shown in Figure 3-3 for reference. This line represents the observed correlation in $\delta^{18} \mathrm{O}-\delta \mathrm{D}$ values of precipitation samples from around the world, and has the equation $\delta \mathrm{D}=8 \delta^{18} \mathrm{O}+10$ (Craig, 1961). Groundwater from the study area plots along a trend that parallels this line, indicating a meteoric origin. Samples from central Oasis Valley plot in a tight cluster that overlaps with the Pahute Mesa samples, but are slightly enriched in heavy isotopes relative to Pahute Mesa groundwaters. This slight enrichment is significant in that it suggests the Oasis Valley groundwater is a mixture of Pahute Mesa groundwater with a smaller component of isotopically heavy local recharge. Mixing relationships are linear on this plot. Hence, one possible mixing component is local recharge from precipitation on Pahute Mesa, which is best represented in Figure 3-3 by the Fortymile Wash samples. Groundwater from the Tolicha Peak area is another potential mixing component. WW-8 groundwater may itself be a mixture of deep "regional" flow beneath Pahute Mesa with a local recharge component, although this sample is heavily weighted toward the local mixing component as compared to the Oasis Valley samples. The groundwater mixing processes implied by these data are consistent with the results of geochemical modeling simulations discussed in Chapter 4.

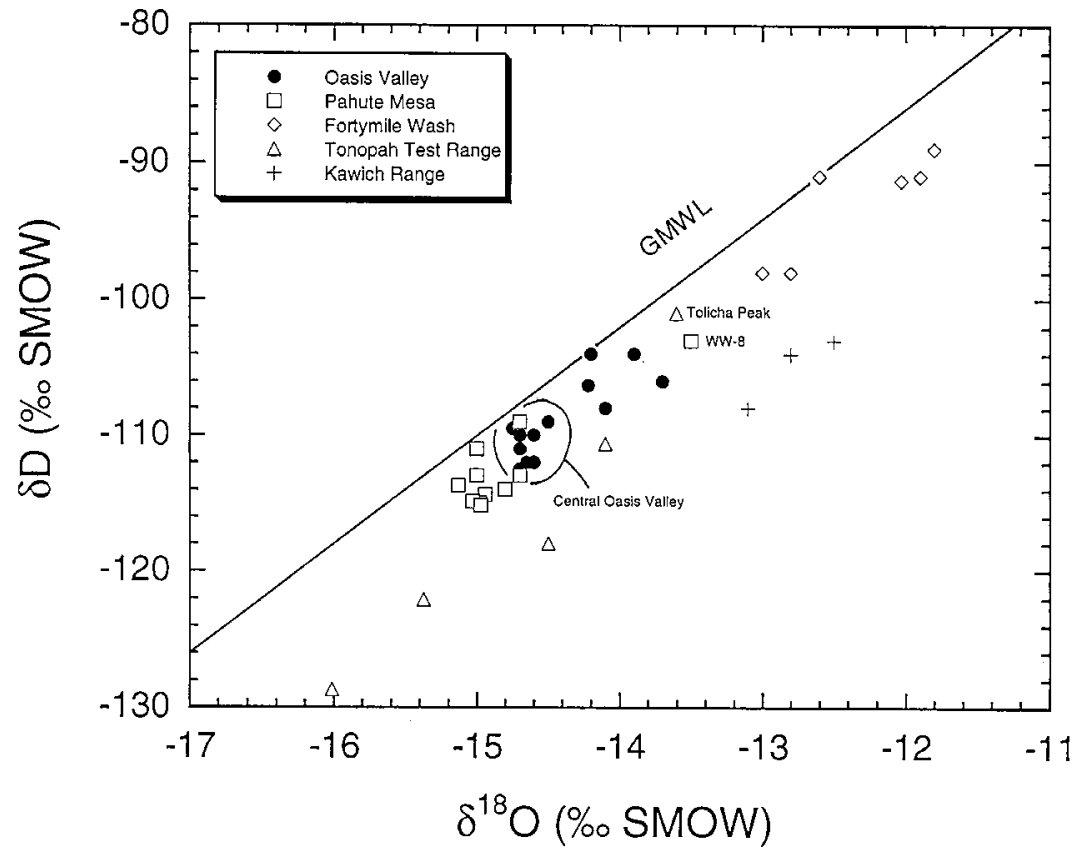

Figure 3-3. Comparison of $\delta \mathrm{D}$ and $\delta^{18} \mathrm{O}$ of groundwater in the Pahute Mesa-Oasis Valley region.

\subsubsection{Carbon Isotopes}

Carbon-14 is a naturally occurring radioisotope with a half-life of 5,730 years that is widely used to date groundwaters with ages less than about 40,000 years. Dissolved inorganic carbon (DIC) in groundwater originates from two main sources: (1) the biogenic production of $\mathrm{CO}_{2}$ in the soil zone, and (2) the chemical dissolution of carbonate minerals (Fontes, 1983). The latter process can significantly modify the ${ }^{14} \mathrm{C}$ content of the DIC, and the interpretation of ${ }^{14} \mathrm{C}$ ages 
therefore requires the careful evaluation of mineral dissolution and isotope exchange processes (Mook, 1980). In Chapter 4, the NETPATH computer code (Plummer et al., 1991) is used to simulate chemical reactions and mixing along the flowpath, to predict variations in carbon isotope values and to estimate groundwater travel times. In this section, the variations in carbon isotope data within the Pahute Mesa-Oasis Valley flow system are described, and the key processes influencing these variations are discussed.

DIC samples were analyzed for both their stable carbon isotope ratio $\left({ }^{13} \mathrm{C} /{ }^{12} \mathrm{C}\right.$, reported as $\delta^{13} \mathrm{C}$ values) and for their radiocarbon $\left({ }^{14} \mathrm{C}\right)$ activity. The results are tabulated in Appendix $\mathrm{B}$, and the geographic distribution of data is shown in Figure 3-4. Groundwater $\delta^{13} \mathrm{C}$ values range from $-13.1 \%$ * to $-1.4 \%$ and ${ }^{14} \mathrm{C}$ values range from 5 to 104 pmc. These data are plotted in Figure 3-5. A majority of the samples have ${ }^{14} \mathrm{C}$ values less than $25 \mathrm{pmc}$ and $\delta^{13} \mathrm{C}$ values greater than $-5 \%$, implying significant reaction with carbonate minerals (see discussion below).

Comparatively higher ${ }^{14} \mathrm{C}$ activities in the samples from Water Pipe Butte Spring and the UE-29a wells in Fortymile Canyon reflect relatively recent groundwater recharge.

Recent recharge that has undergone minimal reaction with carbonate minerals is represented by the sample from Water Pipe Butte Spring, with a ${ }^{14} \mathrm{C}$ value of $105 \mathrm{pmc}$ and a $\delta^{13} \mathrm{C}$ value of $-13.1 \%$ (Figure 3-5). This spring emerges from a perched aquifer in rhyolitic volcanic rocks. Radiocarbon values greater than $100 \mathrm{pmc}$ indicate the presence of ${ }^{14} \mathrm{C}$ derived from the atmospheric testing of nuclear weapons (Levin et al., 1980). The $\delta^{13} \mathrm{C}$ value for this spring is consistent with open system equilibration of soil $\mathrm{CO}_{2}$ with dissolved bicarbonate $\left(\mathrm{HCO}_{3}^{-}\right)$, which results in a 9\%o enrichment in the bicarbonate relative to the $\mathrm{CO}_{2}$ gas (Mook et al., 1974). Hence, groundwater from Water Pipe Butte Spring likely equilibrated with soil $\mathrm{CO}_{2}$ having a $\delta^{13} \mathrm{C}$ value near $-22 \%$. This value lies within the range of $\delta^{13} \mathrm{C}$ values observed for soil $\mathrm{CO}_{2}$ gas in shallow boreholes at Yucca Mountain (e.g., Yang et al., 1996).

Groundwater from the UE-29a \#1 and \#2 wells have uncorrected ${ }^{14} \mathrm{C}$ ages of 2,300 and 2,600 years, respectively. However, the presence of bomb-pulse tritium in these samples indicates that the mean age of the water is probably $<50$ years. The reaction of dissolved soil $\mathrm{CO}_{2}$ with older carbonate minerals may account for the "low" ${ }^{14} \mathrm{C}$ values. For example, Boughton (1986) measured the $\delta^{13} \mathrm{C}$ values of caliche from the NTS and found values ranging from -7.9 to $-4.6 \%$, with an average value of $-6.6 \%$. Assuming an initial $\delta^{13} \mathrm{C}$ value similar to that of Water Pipe Butte Spring (-13.1\%o), limited reaction with pedogenic carbonate could account for both the increase in $\delta^{13} \mathrm{C}$ values (to around $-10 \%$ ), and the decrease in ${ }^{14} \mathrm{C}$ values (to around $75 \mathrm{pmc}$ ) in the UE-29a groundwaters.

Relative to Water Pipe Butte Spring and the UE-29a wells, most groundwaters in the Pahute Mesa-Oasis Valley flow system have evolved toward much higher $\delta^{13} \mathrm{C}$ values and lower ${ }^{14} \mathrm{C}$ values (Figure 3-5). This pattern of evolution is consistent with more extensive water-rock interaction with carbonate minerals. Calcite is commonly found as secondary fracture coatings in the saturated volcanic aquifers beneath Pahute Mesa. The average $\delta^{13} \mathrm{C}$ value of these fracturelining calcites is around $+1.6 \%$ o (based on 11 measurements) and all samples that were analyzed contained less than $1 \mathrm{pmc}{ }^{14} \mathrm{C}$ (see Chapter 1 for additional details). The carbon isotope

* DIC $\delta^{13} \mathrm{C}$ values were measured at both DRI and LLNL. There is a small, systematic difference in the results obtained from the two different laboratories due to differences in sample preparation methods. In general, the LLNL results are up to $1 \%$ enriched in ${ }^{13} \mathrm{C}$ relative to the DRI results. Data from both labs are reported in Appendix B, but for the sake of consistency, only the LLNL data are discussed here. 
composition of deep groundwater beneath Pahute Mesa (e.g., U-20 WW) may be largely controlled by dissolution/precipitation or isotope exchange reactions with these fracture-lining minerals.

Figure 3-4. Carbon isotopic values of groundwater in the Pahute Mesa-Oasis Valley region. 


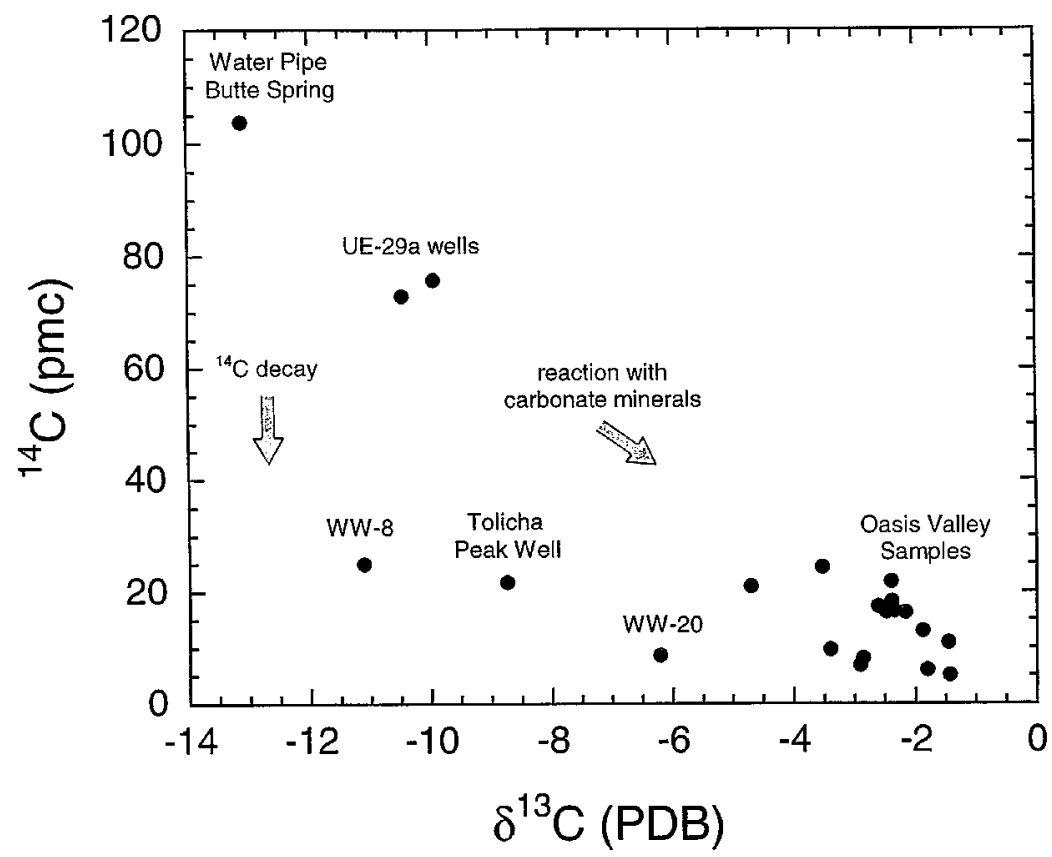

Figure 3-5. Comparison of percent modern carbon and $\delta^{13} \mathrm{C}$ of groundwater in the Pahute Mesa-Oasis Valley region.

Wells ER-OV-1 and ER-OV-6a are situated near the mouth of Thirsty Canyon, downgradient from Pahute Mesa. Compared to U-20 WW, these groundwaters have slightly lower ${ }^{14} \mathrm{C}$ values and higher $\delta^{13} \mathrm{C}$ values, implying additional reaction with carbonate minerals along the flowpath from Pahute Mesa to Oasis Valley. In the Oasis Valley discharge area, ${ }^{14} \mathrm{C}$ values actually increase and $\delta^{13} \mathrm{C}$ values decrease relative to ER-OV-1 and -6a. These data suggest mixing with a younger recharge component, although the fluid volume of the younger component must be small to preserve the general continuity in $\delta^{18} \mathrm{O}$ and $\delta \mathrm{D}$ values between Pahute Mesa and Oasis Valley.

White and Chuma (1987) discuss the likelihood of processes in the discharge area involving dissolution and isotopic exchange reactions with soil $\mathrm{CO}_{2}$ and young pedogenic carbonate minerals, and consumption of $\mathrm{CO}_{2}$ by silicate hydrolysis reactions. These processes do not require the addition of a large volume of fluid. The depth to groundwater will control the extent of open versus closed system reactions. White and Chuma (1987) infer that isotopic equilibrium is maintained between soil gas and shallow groundwater by exchange processes, resulting in progressive increases in ${ }^{14} \mathrm{C}$ and the partial pressure of $\mathrm{CO}_{2}$ and decreases in $\delta^{13} \mathrm{C}$ in the groundwater system. Under these conditions, calcite saturation is maintained by the dissolution of isotopically young soil zone caliche.

\subsubsection{Tritium}

Tritium $\left({ }^{3} \mathrm{H}\right)$ is a radioisotope of hydrogen with a half-life of 12.3 years. The natural production rate of tritium in the atmosphere is on the order of $5 \mathrm{TU}(16 \mathrm{pCi} / \mathrm{L})$ per year (Vogel et al., 1974), where $1 \mathrm{TU}$ is equivalent to an activity of $3.2 \mathrm{pCi} / \mathrm{L}$. However, during the atmospheric testing of nuclear weapons, tritium concentrations in precipitation rose to more than 2,200 TU (Gat, 1980). Atmospheric levels of tritium have steadily declined since 1963 to near natural 
levels. Bomb-pulse tritium provides a useful tracer for identifying young groundwaters with residence times less than about 50 years.

Tritium data obtained during this study are given in Appendix B, and the geographic distribution of data is shown in Figure 3-6. Most of the wells and springs have tritium levels below the analytical precision limit of $0.5 \mathrm{TU}(1.6 \mathrm{pCi} / \mathrm{L})$. Exceptions to this are UE-29a \#1 and \#2 (with 13.6 and 12.2 TU, respectively), Water Well 20 (1.2 TU), ER-OV-1 (1.0 TU) and ER-OV-6a (0.6 TU). Elevated tritium levels in the UE-29a wells indicate relatively young groundwater ages. The $\delta \mathrm{D}$ and $\delta^{18} \mathrm{O}$ values for UE-29a groundwaters are similar to that of perched water at Water Pipe Butte Spring, located $\sim 1 \mathrm{~km}$ north of the wells, implying that UE-29a groundwater is locally recharged.

Small amounts of ${ }^{3} \mathrm{H}$ in groundwater from Water Well 20 probably reflect the close proximity of this well to underground nuclear test cavities. The small amounts of tritium in ER-OV-1 and ER-OV-6a probably originated from drilling fluids during well completion, or local mixing with small amounts of recent recharge.

\subsubsection{Helium Isotopes}

Dissolved noble gases are highly conservative trace elements in groundwater systems that have been variously used to investigate groundwater origin, residence time, history and mixing processes (Hudson, 1994). Helium $\left({ }^{3} \mathrm{He},{ }^{4} \mathrm{He}\right.$ ) isotopes are of particular interest for qualitative determinations of groundwater residence times, for recognizing interactions with fluids of mantle origin, and for dating young waters that contain tritium. Helium isotope results for the Pahute Mesa-Oasis Valley region are presented in Appendix B, and the geographic distribution of data is shown in Figure 3-7. Data for individual locations in Figure 3-7 include: (1) the ${ }^{3} \mathrm{He} /{ }^{4} \mathrm{He}$ ratio of the sample relative to the ${ }^{3} \mathrm{He} /{ }^{4} \mathrm{He}$ ratio of air (also referred to as $\mathrm{R} / \mathrm{R}_{\mathrm{a}}$ ), and (2) the ${ }^{4} \mathrm{He}$ concentration (in atoms per gram of water).

The solubility of helium in groundwater during recharge depends on both temperature and atmospheric pressure (altitude) (Benson and Krause, 1976). For example, if recharge occurs at an elevation of $2,000 \mathrm{~m}$ and a temperature of $10^{\circ} \mathrm{C}$, the equilibrium solubility of helium will be $\sim 10^{12}$ atoms ${ }^{4} \mathrm{He}$ per gram of water. This is similar to the conditions that might be anticipated for recharge on Pahute Mesa. During recharge, air-saturated water will typically have an $R / R_{a}$ value near 1 (where $\mathrm{R}_{\mathrm{a}}=1.38 \times 10^{-6}$ ). In many instances, helium gas concentrations measured in groundwater are notably higher than the value expected for atmospheric equilibrium. In tritiumabsent waters, the origin of the excess helium gas can be ascribed to three possible sources: "excess air," crustal helium, and mantle helium.

"Excess air" is commonly inherited during recharge due to the solution of air bubbles trapped by infiltrating water (Heaton and Vogel, 1981). The amount of helium from excess air can be quantified by measuring the dissolved concentrations of other conservative gases that are solely of atmospheric origin (e.g., neon, krypton, and xenon). The difference between the observed and the equilibrium concentrations of these gases determines the amount of excess air in solution. In older groundwaters, $\mathrm{R} / \mathrm{R}_{\mathrm{a}}$ values $<1$ often indicate the accumulation of excess ${ }^{4} \mathrm{He}$ (referred to as crustal helium) derived from the natural $\alpha$-decay of uranium-bearing minerals in the aquifer matrix (Andrews and Lee, 1979; Torgersen and Ivey, 1985). Conversely, $R / R_{a}$ values $>1$ indicate excess ${ }^{3} \mathrm{He}$, which may originate from tritium decay, or from helium derived from the earth's mantle (Schlosser, 1992). Mantle-derived ${ }^{3} \mathrm{He}$ fluxes are commonly observed in 
tectonically active regions, particularly in areas of active crustal extension such as the Great Basin (O’Nions and Oxburgh, 1988; Welhan et al., 1988).

Figure 3-6. Tritium activity of groundwater in the Pahute Mesa-Oasis Valley region. 
Figure 3-7. Helium isotopes of groundwater in the Pahute Mesa-Oasis Valley region. 
A number of wells and springs in Oasis Valley contain significant amounts of excess ${ }^{4} \mathrm{He}$ and ${ }^{3} \mathrm{He}$, as indicated by ${ }^{4} \mathrm{He}$ concentrations $>10^{12}$, and $\mathrm{R} / \mathrm{R}_{\mathrm{a}}$ values $>1$. For example, Baileys Hot Spring has a ${ }^{4} \mathrm{He}$ concentration of $1.3 \times 10^{13}$ atoms per gram (atoms $/ g$ ), and a $\mathrm{R} / \mathrm{R}_{\mathrm{a}}$ value of 1.73. The high ${ }^{4} \mathrm{He}$ concentration suggests the accumulation of crustal helium in the groundwater, implying long aquifer residence times. The absence of tritium in most of the Oasis Valley samples suggests the ${ }^{3} \mathrm{He}$ excess is mantle-derived. Helium has a high diffusivity, which enhances its mobility in natural systems. Major structural features, such as the Thirsty Canyon lineament, may have roots extending to the deep crust or upper mantle, thereby providing a conduit for the transmission of deep gases (see Grauch et al., 1997).

Figure 3-8 is a plot of $\mathrm{R} / \mathrm{R}_{\mathrm{a}}$ versus $10^{12} /{ }^{4} \mathrm{He}$ for Oasis Valley-Pahute Mesa groundwaters. The $\mathrm{x}$-axis is the ratio of the assumed helium concentration during recharge $\left(10^{12}\right)$ relative to the ${ }^{4} \mathrm{He}$ concentration in the sample. Mixing relationships are linear in this diagram. Water in equilibrium with air at $2,000 \mathrm{~m}$ elevation and $10^{\circ} \mathrm{C}$ is represented as a solid circle, with a value of 1 for both $\mathrm{R} / \mathrm{R}_{\mathrm{a}}$ and $10^{12} /{ }^{4} \mathrm{He}$ (in atoms $/ \mathrm{g}$ ). The helium isotope composition of any given sample is the sum of the equilibrium atmospheric component, the "excess air" component, the crustal component (low ${ }^{3} \mathrm{He} /{ }^{4} \mathrm{He}$ ratio), and the mantle component (high ${ }^{3} \mathrm{He} /{ }^{4} \mathrm{He}$ ratio). Vectors in Figure 3-8 illustrate the direction and magnitude of increasing crustal and mantle helium components relative to the equilibrium air composition. Although an excess air vector is not shown, it would be represented in Figure $3-8$ by a horizontal line with $R / R_{a}=1$, with increasing amounts of excess air corresponding to decreasing $10^{12} /{ }^{4} \mathrm{He}$ values (i.e., values $<1$ ).

As an example, consider the helium isotope composition of ER-OV-3a (see Figure 3-8). This sample plots well to the left of the equilibrium value for air in water, with $R / R_{a}=1.1$ and $10^{12} /{ }^{4} \mathrm{He}=0.4$. These values imply a moderate excess of ${ }^{4} \mathrm{He}$ and a relatively small excess of ${ }^{3} \mathrm{He}$ relative to equilibrium with air. The crustal helium excess in ER-OV-3a is estimated to be slightly greater than $50 \%$, as determined by projecting an orthogonal line from the "crustal He" vector to the ER-OV-3a data point (Figure 3-8). The mantle helium excess in ER-OV-3a is $\sim 8 \%$, and was estimated in a similar manner using the "mantle He" vector in Figure 3-8. By difference, the remaining helium excess in the sample $(\sim 40 \%)$ is attributed to excess air that was dissolved during recharge).

The helium isotopic compositions of the UE-29a wells and Goss Spring suggest recent groundwater recharge, or recent equilibration between atmospheric and groundwater helium (Figure 3-8). High CFC concentrations in these samples support this interpretation (section 3.2.5). In addition, the UE-29a wells have stable isotope and ${ }^{14} \mathrm{C}$ values that are consistent with local recharge. The small ${ }^{3} \mathrm{He}$ excess in the UE-29a samples is probably derived from the decay of tritium present in these young waters (section 3.2.3). The mean age of young groundwaters can be quantitatively determined by measuring both the ${ }^{3} \mathrm{H}$ and the ${ }^{3} \mathrm{He}$ concentrations of the sample (e.g., Poreda et al., 1988; Schlosser, 1992). This technique, known as ${ }^{3} \mathrm{H}-{ }^{3} \mathrm{He}$ dating, was used to calculate the following mean groundwater ages for the UE-29a wells:

\begin{tabular}{cccc}
\hline Sample & ${ }^{3} \mathrm{H}^{3} \mathrm{He}$ age $(\mathrm{yrs})$ & Well depth $(\mathrm{m} \mathrm{bgs})$ & Open interval (m bgs) \\
\hline UE-29a\#1 & $1.93 \pm 0.49$ & 66 & $11-66$ \\
UE-29a\#2 & $5.76 \pm 0.59$ & 422 & $87-213$ \\
\hline
\end{tabular}




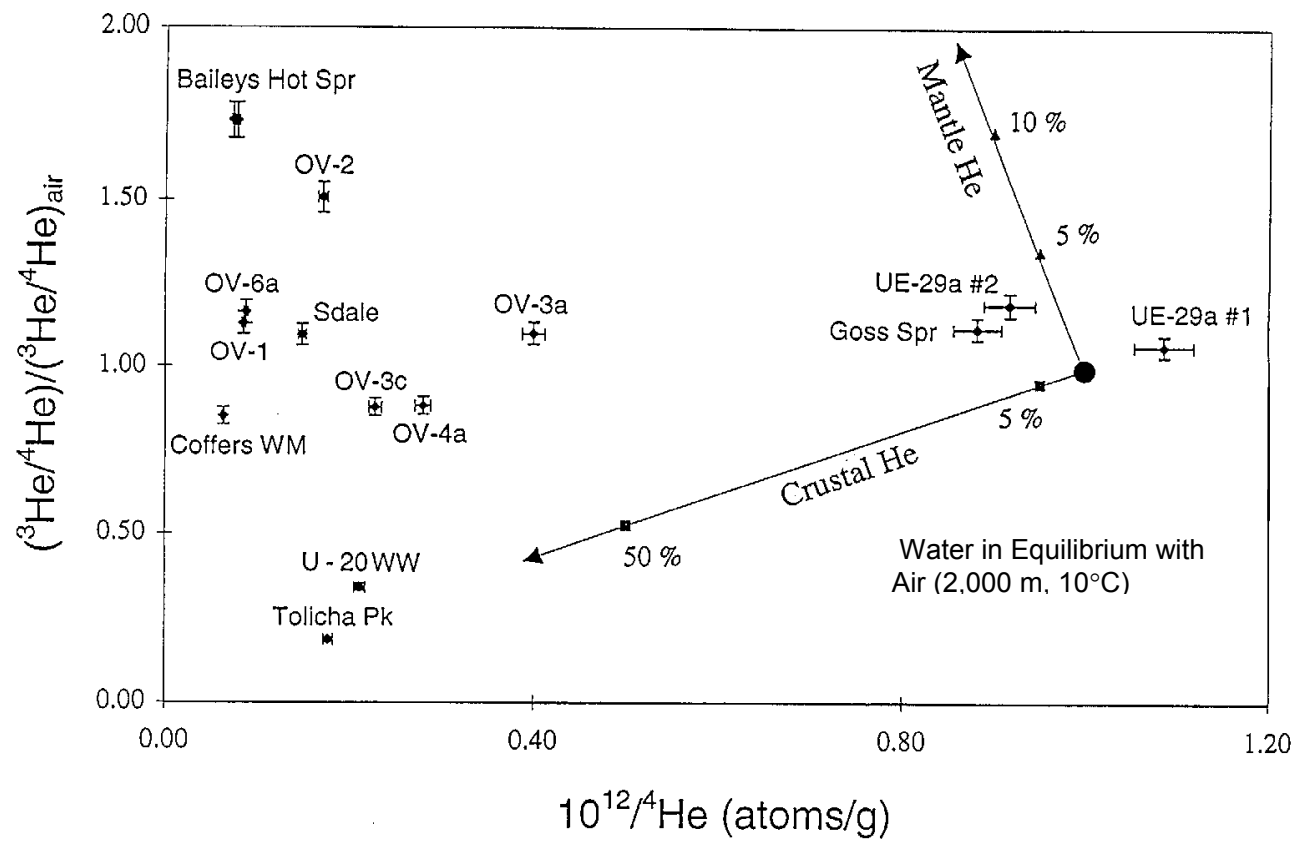

Figure 3-8. Comparison of helium isotopes and helium concentrations in groundwater in the Pahute Mesa-Oasis Valley region.

The tritium concentrations in these samples $(\sim 40 \mathrm{pCi} / \mathrm{L}$; Appendix B) resemble that of recent precipitation in southern Nevada (Milne et al., 1987), suggesting the estimated ages are reasonable. The age difference between UE-29a \#1 and \#2 probably reflects differences in well depths and perforation intervals.

In contrast to the UE-29a wells, isotopic evidence indicates that Goss Spring is not locally recharged. The helium isotope results for Goss Spring probably indicate atmospheric reequilibration in the discharge zone, particularly given the lack of tritium in this sample. Lastly, it should be noted that U-20 WW and Tolicha Peak Well are dominated by crustal ${ }^{4} \mathrm{He}$ (Figure 38 ), implying that mantle ${ }^{3} \mathrm{He}$ is added to the Oasis Valley wells and springs downgradient of Pahute Mesa.

\section{$\underline{3.3 .5 \text { Chlorofluorocarbons }}$}

Chlorofluorocarbons (CFCs) are relatively stable, synthetic, halogenated alkanes that were first produced in 1931 as the refrigerant dichlorodifluoromethane $\left(\mathrm{CCl}_{2} \mathrm{~F}_{2}\right.$ or $\left.\mathrm{CFC}-12\right)$. Trichlorofluoromethane $\left(\mathrm{CCl}_{3} \mathrm{~F}\right.$ or $\left.\mathrm{CFC}-11\right)$ production began in 1936 , and production of trichlorotrifluoroethane $\left(\mathrm{C}_{2} \mathrm{Cl}_{3} \mathrm{~F}_{3}\right.$ or CFC-113) began in the $1960 \mathrm{~s}$. Worldwide CFC production for use as refrigerants, aerosol propellants, cleaning agents, solvents, and blowing agents used in the production of foam rubber and plastics exceeded 44,000 tons in 1994.

Atmospheric CFCs are partitioned into water by gas-liquid exchange equilibria. Because there are no natural CFC sources (Plummer et al., 1993), the concentration of CFCs in groundwater can be used to estimate groundwater age. Dissolved concentrations are converted to air partial pressures using Henry's Law solubility constants, and are compared to historic atmospheric values to determine when the groundwater was last in contact with air (Busenberg and Plummer, 1992). This technique has been widely used to date groundwaters with ages $\leq 50$ 
years (e.g., Busenberg et al., 1993; Dunkle et al., 1993; Plummer et al., 1993; Ekwurzel et al., 1994; Cook et al., 1995; Oster et al., 1996; Szabo et al., 1996). In areas where the unsaturated zone is greater than $\sim 30 \mathrm{~m}$ in thickness, calculated CFC ages may be older than the actual groundwater recharge age due to diffusional retardation effects in the unsaturated zone (Weeks et al., 1982; Busenberg et al., 1993; Cook and Solomon, 1995; Johnston et al., 1998).

All of the wells and springs sampled during this study were found to contain some CFCs (Appendix B). The pathways by which CFCs are introduced to the groundwater include: (1) the recent recharge of young groundwater; (2) the natural diffusion of unsaturated-zone gases into the groundwater; and (3) the artificial introduction of atmospheric gases into the aquifer during well drilling and development.

In the recently completed ER-OV wells (Robledo et al., 1998), the most likely source of CFCs is the introduction of atmospheric gases during well drilling and development. For example, the ER-OV-2 and ER-OV-6a wells contain CFC-113 levels that are double the highest atmospheric concentration, clearly implicating contamination during drilling. Most of the EROV samples do not contain measurable tritium, suggesting the CFCs did not originate from recent recharge, or mixing of young local groundwater with older regional groundwater. Where tritium and CFCs are both present (ER-OV-1 and -6a), a component of young local recharge is possible. However, anomalous CFC levels in ER-OV-1 and -6a indicate that contamination during drilling is more plausible.

In the natural discharge areas of Oasis Valley (e.g., Goss Spring and Baileys Hot Spring), CFCs are observed in the groundwater, but tritium is not. This implies that atmospheric gases either diffuse through the unsaturated zone to the water table, or enter the springs directly from atmospheric contact in the discharge zone (Busenberg et al., 1993; L.N. Plummer, U.S. Geological Survey, personal communication, 1999). CFC concentrations in Goss Spring and Baileys Hot Spring yield 23- and 34-year CFC ages, respectively. Consistent age estimates are obtained from both the CFC-11 and CFC-12 concentrations, implying that the CFCs originated from unsaturated zone gases at a location upgradient of the spring discharge zone. Surface outcrops of volcanic rocks occur near both springs, and fractures within these rocks may provide preferential avenues for atmospheric gases to enter the unsaturated zone near the springs. This assertion is supported by data from well ER-OV-3a3, which is completed in volcanic tuff $\sim 0.2$ $\mathrm{km}$ upgradient from Goss Spring. Although the CFC-11 and -12 levels measured in this well are only about $30 \%$ of those measured in Goss Spring, they are 5 to 10 times greater than most other ER-OV wells. These results are consistent with relatively rapid gas transport through fractures in the rock.

High CFC concentrations are also observed in well UE-29a \#1, in Fortymile Wash. The average CFC age of this groundwater ranges from about 10 (CFC-113) to 21 (CFC-11) years. The range in estimated ages is inferred to reflect differences in diffusion rates of the CFC gases through the thick unsaturated zone in the UE-29a recharge area (cf. Weeks et al., 1982). Relatively slow gas diffusion rates are also suggested by differences in the CFC and ${ }^{3} \mathrm{H}-{ }^{3} \mathrm{He}$ ages. The ${ }^{3} \mathrm{H}-{ }^{3} \mathrm{He}$ age for UE-29a \#1 is only 2 years (see section 3.2.4), which implies somewhat independent fluid and gas pathways to the saturated zone.

In most other pre-existing (non ER-OV) wells, the CFC concentrations are relatively low. In WW-8, U-20 WW, and the Tolicha Peak well, low levels of CFCs probably originated from atmospheric contamination during sampling. Although atmospheric gas diffusion through the 
unsaturated zone is possible, the great depth to groundwater at these locations (up to $700 \mathrm{~m}$ ) suggests that contamination during sampling is a more likely explanation for the presence of low-level CFCs.

\subsubsection{Trace Element Chemistry}

Trace elements are defined as elements that are present in natural waters at concentrations less than $1 \mathrm{mg} / \mathrm{L}$ (Drever, 1982). In the Oasis Valley samples, trace element concentrations range from hundreds of micrograms per liter (e.g., $\mathrm{Li}$ and $\mathrm{Sr}$ ) to below nanogram per liter levels (e.g., REEs). Several statistical techniques (multivariate and univariate) were applied to analyze the large trace element data set measured for each sample (Appendix B). These statistical techniques include cluster analysis, principal components analysis, and population partitioning. The Geographical Information System (ARC/VIEW GIS) was used for geographical visualization of the statistical results. A subset of 19 trace elements (Table 3-1) was selected for statistical evaluation on the basis of analytical reproducibility. Only elements with analytical differences of less than $50 \%$ between duplicate samples were included in the statistical analyses.

K-means cluster analysis was used to detect grouping patterns in the trace element data set using the software program STATISTICA (Statistica, 1995). Standardized data were utilized to ensure the same influence of each of the trace elements on the clustering (Wold et al., 1987). $\mathrm{K}$-means clustering requires the predetermination of the number of desired clusters; six clusters were selected on the basis of prior hierarchical cluster analysis results (Farnham et al., 2000). The samples were distributed among the six clusters by minimizing the variance within each cluster and maximizing the variance between the individual clusters. The geographical distribution of the members of the six clusters (i.e., individual spring and well samples) is identified in Figure 3-9. All replicate and duplicate measurements clustered together in the $\mathrm{K}$-means cluster analysis, indicating that the groundwater trace element chemistry shows little variation over time at individual locations.

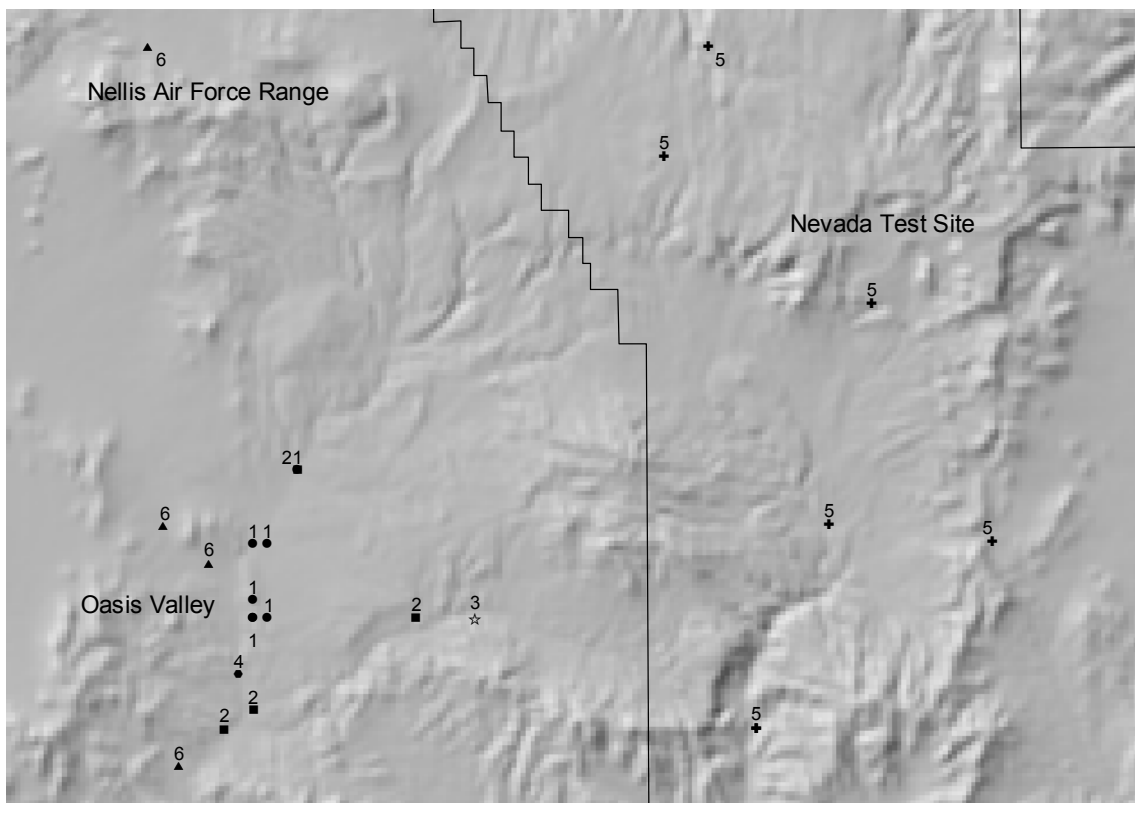

Figure 3-9. Results of K-means clustering. 
The results of the K-means cluster analysis are as follows. Groundwater from the northcentral part of Oasis Valley forms one distinct cluster (cluster 1) with the exception of the ER-OV-6a sample. ER-OV-6a clusters with the southern Oasis Valley samples (ER-OV-4 and Frans Spring) and ER-OV-3c (cluster 2). Groundwaters from Coffers Windmill and Baileys Hot Spring form their own distinct clusters (cluster 3 and 4). Cluster 5 includes all groundwater samples collected from wells on the NTS. Cluster 6 comprises groundwater from the western side of Oasis Valley (ER-OV-5, Springdale Well, and Beatty Water District Well) together with the Tolicha Peak well.

The relative similarity between each of the K-means clusters was quantitatively evaluated by calculating the Euclidean distances (ED) between each of the clusters. Small EDs imply strong similarities between data clusters. The smallest ED (0.70) is observed for clusters 1 and 2, indicating that most of the Oasis Valley groundwaters have similar trace element compositions. Relatively low EDs were also observed between cluster 3 and clusters 1, 2, and 5 (ED values of $1.00,0.98$ and 0.93 , respectively). These results indicate that groundwater from Coffers Windmill (cluster 3) is similar to both the NTS (cluster 5) and Oasis Valley (clusters 1 and 2) groundwaters. Not surprisingly, larger EDs were obtained for groundwater clusters from widely separated geographic areas, such as the NTS (cluster 5) and western Oasis Valley (cluster 6) samples $(\mathrm{ED}=1.15)$. The largest EDs are for cluster $4(1.23 \leq \mathrm{ED} \leq 1.88)$, revealing that the trace element composition of Baileys Hot Spring is chemically distinct from all other samples.

The multivariate statistical technique, principal components analysis (PCA), was also used to decipher patterns within the trace element data set. PCA has been widely applied in geosciences, and many excellent descriptions of the technique are found in the literature (e.g., Jolliffe, 1986; Wold et al., 1987; Brown, 1998; Wackernagel, 1995). With PCA, the original data are modeled using principal component scores and loadings. The principal component scores are linear combinations of the original standardized data with the loadings as the coefficients. In other words, the PC score combines information on all of the trace element measurements for a given sample into a single number, and the loadings indicate the relative contribution of each element to that score. Principal components are extracted so that the maximum amount of variance is explained by the first principal component and progressively less variance is explained by each subsequent component. The different principal components are orthogonal and therefore independent of one another.

Wells and springs with similar groundwater chemistry plot as clusters on the PC score plots. The loadings are then evaluated to determine the elements that are responsible for these correlations. Elements with the highest loadings make the largest contribution to that component. The loadings can therefore be examined to provide further insight into the processes that are responsible for the similarities or differences in the trace element compositions of different groundwaters.

A plot of the PC scores for the first two principal components is shown in Figure 3-10. Only the averages for the sites that were measured multiple times are used in the PCA. Approximately 50 percent of the variance of the entire trace element data set is explained by the first two principal components (Table 3-1). PC1 clearly separates the NTS and Oasis Valley groundwaters (Figure 3-10). Groundwater samples from Tolicha Peak and Coffers Windmill have PC1 scores that plot between the NTS and Oasis Valley groups, while the Coffers Ranch and Baileys Hot Spring samples do not cluster with any other samples. Whereas PC1 separates the NTS and Oasis Valley groundwaters, PC2 separates the western Oasis Valley group 


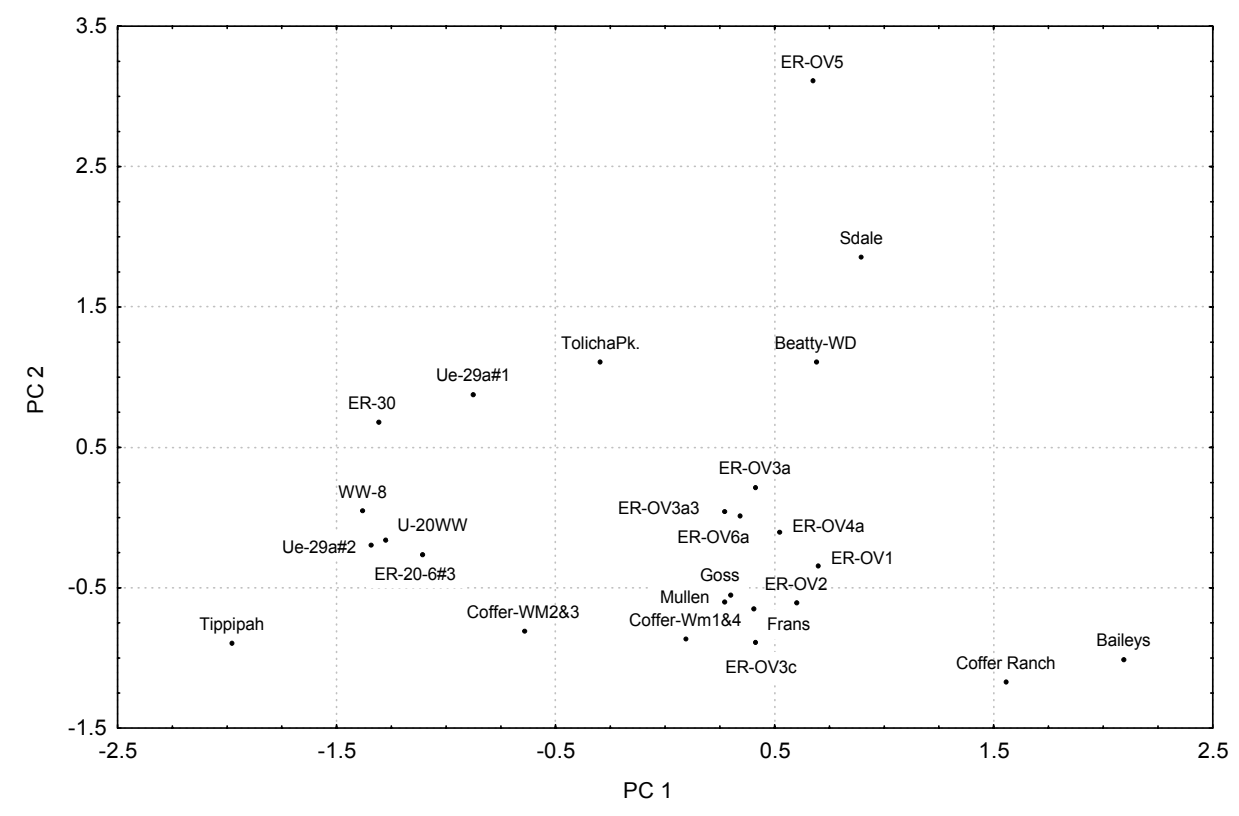

Figure 3-10. Principal component scores.

(ER-OV-5, Springdale well, Tolicha Peak, and Beatty-Water District wells) from all other samples. It is notable that the majority of the Oasis Valley groundwaters form a tight cluster on the PC score plot (Figure 3-10), indicating a strong similarity in trace element chemistry.

The population partitioning method of Singh et al. (1994) was used to identify subpopulations within the data set based on the PC1 scores. Population partitioning is a statistical approach for sub-dividing a sample population into statistically homogeneous sub-samples. PC1 scores were distributed into six sub-populations using the software package SCOUT (Singh, 1996). The results indicate that a majority of the PC1 scores fall into four normally distributed sub-populations (the other two sub-populations contain a total of only three samples). The members of each sub-population are identified in Figure 3-11 with the sub-population number indicating the relative magnitude of the PC scores (e.g., lowest PC scores are observed for subpopulation 1, next lowest PC scores for 2, etc.). The smallest scores are observed for the NTS groundwaters, while the next smallest scores are those of Coffers Windmill and Tolicha Peak. Intermediate PC scores are observed for the majority of the Oasis Valley area, and the largest PC score is reported for Baileys Hot Spring. Spatial interpolation, determined by ARC/VIEW, shows an increasing trend in the PC1 scores from the NTS toward Oasis Valley (Figure 3-11). A second trend is also observed from the north (i.e., starting at Tolicha Peak) toward the western region of Oasis Valley.

The magnitude of the PC score primarily reflects the elements that load highly into the particular principal component (Table 3-1). Thus, higher PC1 scores can be viewed as representing increasing trace element concentrations. The general trend toward increasing PC1 scores (Figure 3-10) between the NTS and Oasis Valley suggests the control of trace elements sensitive to processes occurring along the groundwater flowpath. The spatial interpolation of the PC1 scores (Figure 3-11) provides a map of the groundwater concentration gradient for trace elements that load highly into PC1. The contours for increasing PC1 values are parallel to the 
potentiometric contours beneath Pahute Mesa defined by Blankennagel and Weir (1973). This implies that Pahute Mesa groundwater, with low initial concentrations of elements such as $\mathrm{Li}$, $\mathrm{Ge}, \mathrm{As}, \mathrm{Rb}, \mathrm{Sr}, \mathrm{Mo}, \mathrm{Ru}, \mathrm{Ba}, \mathrm{W}, \mathrm{Tl}$, and $\mathrm{U}$, generally evolves toward higher concentrations of these elements in the direction of Oasis Valley. Key factors influencing this evolution include water-rock interaction, the dissolved oxygen content of the groundwater, and evapotranspiration processes.

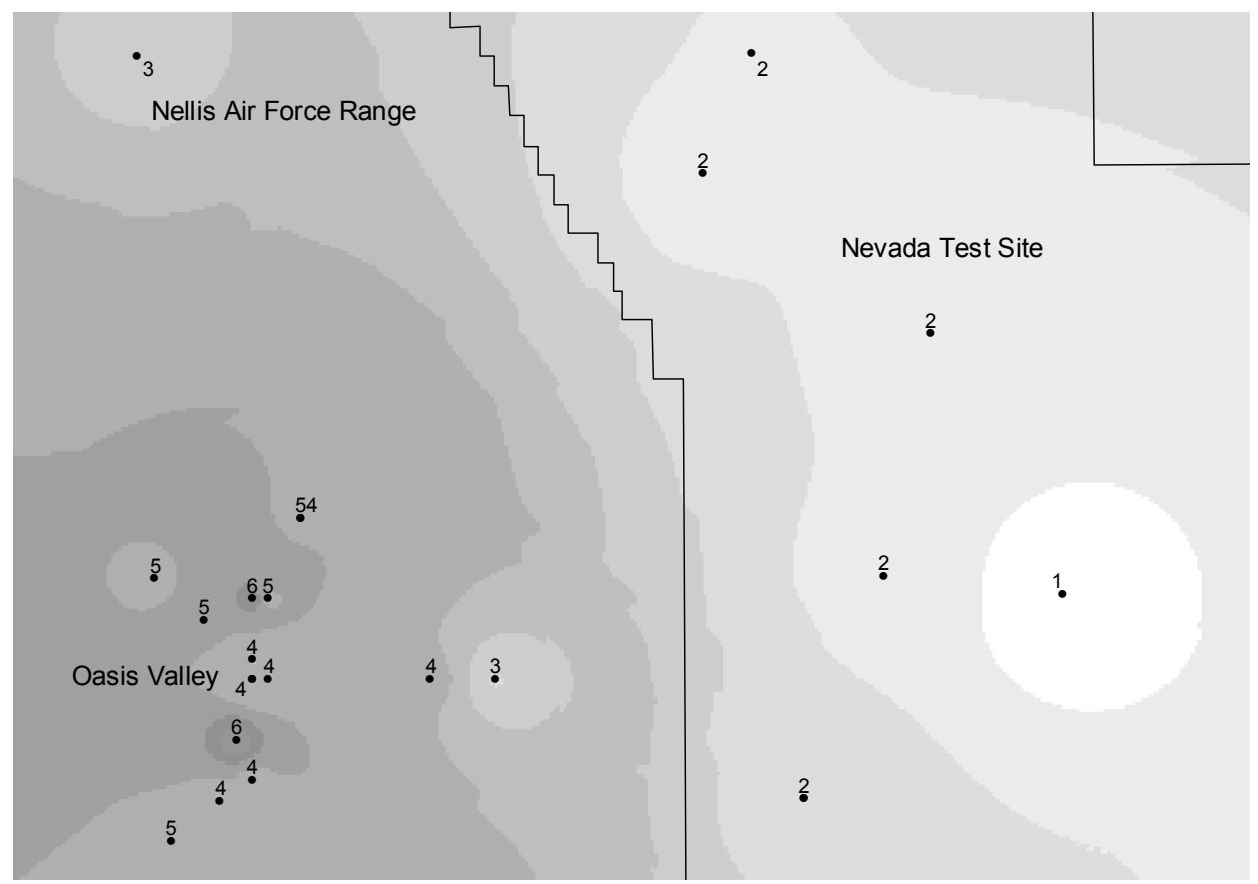

Figure 3-11. Spatial interpolation and population partitioning results for PC1 scores.

In oxygenated, neutral to high-pH waters, some of the trace elements (e.g., As, Mo, W, and U) will form conservative oxyanions. Winograd and Robertson (1982) presented evidence that the regional aquifers of southern Nevada are oxygenated, and White and Chuma (1987) argued that open system conditions (i.e., free atmospheric interaction) exist in the shallow aquifer system in and around Oasis Valley. The concentrations of conservative solutes (e.g., $\mathrm{Na}^{+}$) tend to increase along the flowpath in an aquifer strongly influenced by evapotranspiration. Trace elements such as $\mathrm{Li}, \mathrm{Rb}$, and $\mathrm{Sr}$ tend to behave conservatively (e.g., Edmunds and Smedley, 2000; Edmunds et al., 2002), and are observed to increase in concentration in the Oasis Valley discharge zone, reflecting the buildup of these "salts" in areas with high evapotranspiration rates. Water-rock interactions including weathering, mineral dissolution, and cation exchange will also increase the concentration of these conservative trace elements along the flowpath (Edmunds and Smedley, 2000; Edmunds et al., 2002). A relatively strong correlation $(\mathrm{r}=0.83)$ is observed between ionic strength and PC1 scores. The PC1 scores are also highly correlated with TDS ( $\mathrm{r}=$ $0.91)$, chloride ion $(\mathrm{r}=0.81)$, sulfate ion $(\mathrm{r}=0.89)$, and sodium ion $(\mathrm{r}=0.88)$ concentrations. These correlations again suggest that $\mathrm{PC} 1$ scores reflect a concentration gradient along the flowpath within the volcanic and alluvial aquifers of the NTS-Oasis Valley region. 
Groundwaters of the western Oasis Valley group are clearly separated from the main Oasis Valley group by PC2 (Figure 3-10) with the largest separation observed for ER-OV-5 and Springdale Well. Trace elements that load highly into PC2, include Cr, Se, and V. The concentrations of these trace elements are, in general, higher in these "western" groundwaters compared to other Oasis Valley and NTS groundwaters. These observations suggest that groundwater influx from the west contributes an independent discharge component to Oasis Valley. However, no correlation is observed between PC2 and ionic strength or between PC2 and the major solutes that correlate with PC1 (e.g., $\mathrm{Na}$ and $\mathrm{SO}_{4}$ ). Because each principal component is described by a linear combination of all the trace elements, the small number of variables that load highly into a particular PC do not always characterize the nature of the PC. However, the $\mathrm{PC}$ analysis clearly indicates that the western Oasis Valley groundwaters exhibit significant differences in their trace element compositions compared to other regional groundwaters.

\section{$\underline{\text { 3.3.7 Strontium Isotopes }}$}

Natural strontium comprises four isotopes $\left({ }^{84} \mathrm{Sr},{ }^{86} \mathrm{Sr},{ }^{87} \mathrm{Sr}\right.$, and $\left.{ }^{88} \mathrm{Sr}\right)$, three of which are nonradiogenic and have fixed abundances in terrestrial materials. In contrast, ${ }^{87} \mathrm{Sr}$ is formed by $\beta$-decay of ${ }^{87} \mathrm{Rb}$, which has a half-life of $4.88 \times 10^{10}$ years. The abundance of ${ }^{87} \mathrm{Sr}$ therefore varies in geologic materials depending on their age, their initial $\mathrm{Sr}$ isotopic composition, and their $\mathrm{Rb} / \mathrm{Sr}$ ratio. Groundwater $\delta^{87} \mathrm{Sr}$ values reflect interactions with soil and rocks during recharge and subsequent flow. Because of the low dissolved strontium content of precipitation, infiltration will rapidly adjust to the $\delta^{87} \mathrm{Sr}$ composition of the most soluble soil components. Like other cations, the strontium content of groundwater generally increases along a flowpath due to water-rock interaction. The $\delta^{87} \mathrm{Sr}$ composition of the water may change significantly if the aquifer host rock contains large strontium concentrations in chemically reactive sites.

Conversely, the $\delta^{87} \mathrm{Sr}$ may be buffered from substantial modification following recharge if the aquifer consists of rocks with low strontium contents.

Strontium concentrations in Oasis Valley waters vary from 0.005 to $0.305 \mathrm{mg} / \mathrm{L}$ (data in Appendix B). With the exception of Baileys Hot Spring, groundwater from the Oasis Valleycentral discharge area has Sr concentrations between 0.02 and $0.09 \mathrm{mg} / \mathrm{L}$. These values are typical of groundwater from volcanic aquifers throughout the region. On a plot of Ca versus $\mathrm{Sr}$ concentrations (Figure 3-12), many of the samples plot along a trend that parallels $\mathrm{Ca} / \mathrm{Sr}=100$. $\mathrm{Ca} / \mathrm{Sr}$ ratios in volcanic rocks characteristically range from $\sim 50-100$, whereas higher $\mathrm{Ca} / \mathrm{Sr}$ ratios ( $\sim 500-1000)$ are observed in calcite, limestone and caliche. These data suggest that $\mathrm{Ca} / \mathrm{Sr}$ ratios are influenced by interactions between groundwater and the volcanic aquifer rock. However, nonzero $\mathrm{Ca}$ values at $\mathrm{Sr}=0$ indicate that calcite dissolution is also likely to have contributed to the evolution of groundwaters (Figure 3-12). In addition, $\mathrm{Ca}$ and Sr concentrations negate a simple progressive evolution between groundwater sampled from U-20 WW on Pahute Mesa and central Oasis Valley. Most of the central Oasis Valley groundwaters have larger concentrations of $\mathrm{Ca}$ and $\mathrm{Sr}$ than U-20 WW. However, groundwater from boreholes ER-OV-1 and ER-OV-6a located near the mouth of Thirsty Canyon at an intermediate position along this potential flowpath, reverse this trend by having smaller concentrations of both these cations. Therefore, if groundwater from borehole U-20 WW represents a reasonable starting composition for water evolving along a Pahute Mesa-Thirsty Canyon-central Oasis Valley flowpath as suggested by stable isotope data, additional processes such as local recharge, cation exchange or mineral reactions must be involved to different degrees at different locations. 


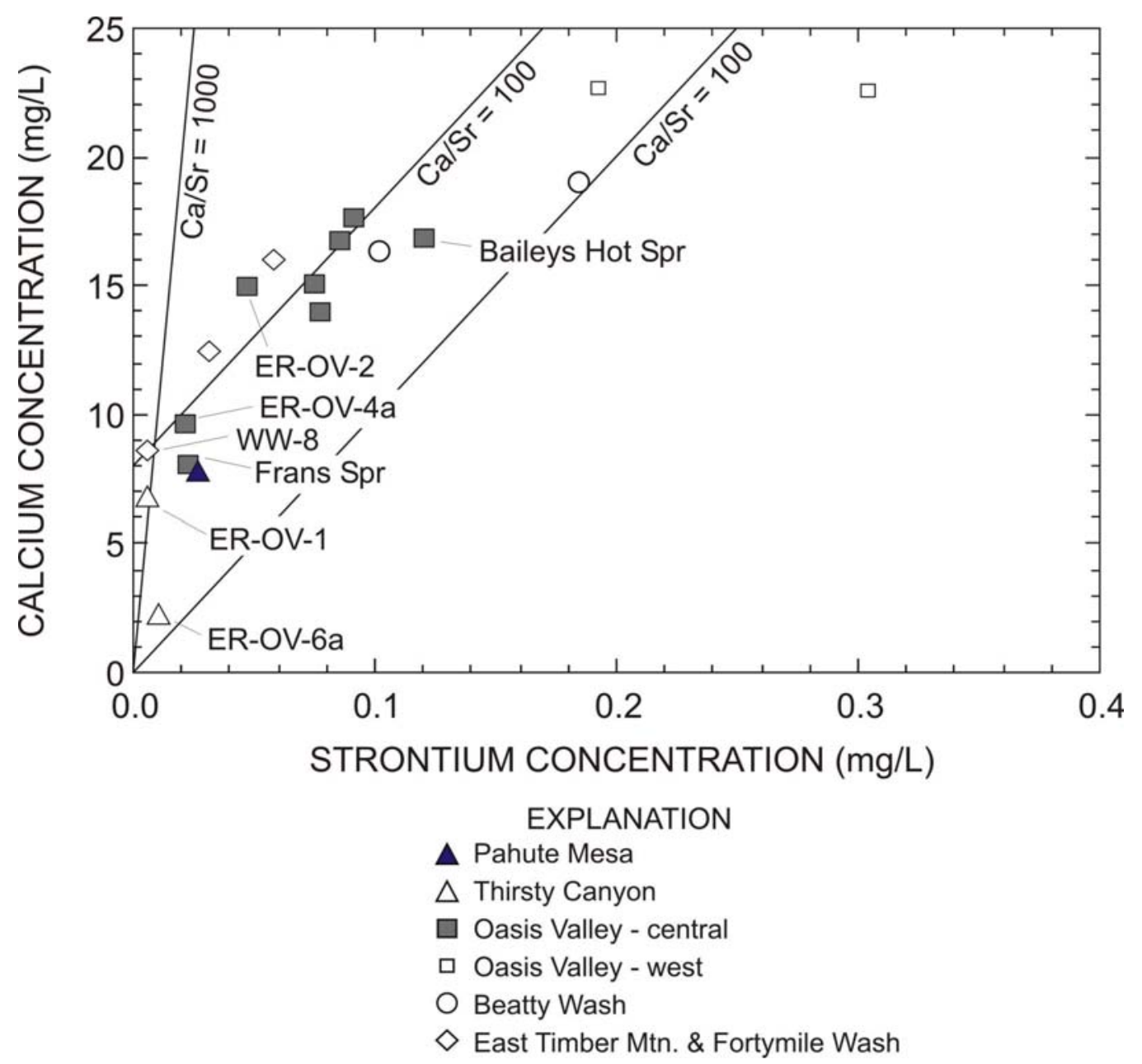

Figure 3-12. Comparison of calcium and strontium concentrations in groundwater in the Pahute MesaOasis Valley region.

The geographic distribution of $\delta^{87} \mathrm{Sr}$ values is shown in Figure 3-13. Values for $\delta^{87} \mathrm{Sr}$ vary from $-0.51 \%$ (Tolicha Peak) to $+3.55 \%$ (Baileys Hot Spring). The largest number of samples is from central Oasis Valley, where groundwater has a limited range of $\delta^{87} \mathrm{Sr}$ values between about +1.2 and $+1.7 \%$ with several notable exceptions. The low value for ER-OV-3a2 $(-1.56 \%)$ is not considered representative of the groundwater system at this site because of the very small rate of production from this well ( $<1 \mathrm{gpm}$; Robledo et al., 1998). The southernmost sample from the central Oasis Valley area also has a smaller $\delta^{87} \mathrm{Sr}$ than the main group ( +0.38 for Frans Spring) and may indicate a contribution from a distinctly lower source as the narrows at Beatty are approached. In contrast, groundwater from Baileys Hot Spring has a $\delta^{87} \mathrm{Sr}$ value that is substantially larger $(+3.55)$ than other samples in this area. The larger $\delta^{87} \mathrm{Sr}$ is consistent with water/rock interactions involving older basement rocks with larger $\delta^{87} \mathrm{Sr}$ values than most of the flowpaths resulting in discharge in central Oasis Valley. A warmer temperature and larger ${ }^{3} \mathrm{He} /{ }^{4} \mathrm{He}$ ratio (section 3.2.4) relative to nearby discharge sites supports the likelihood of a deeper flowpath for Baileys Hot Spring. 


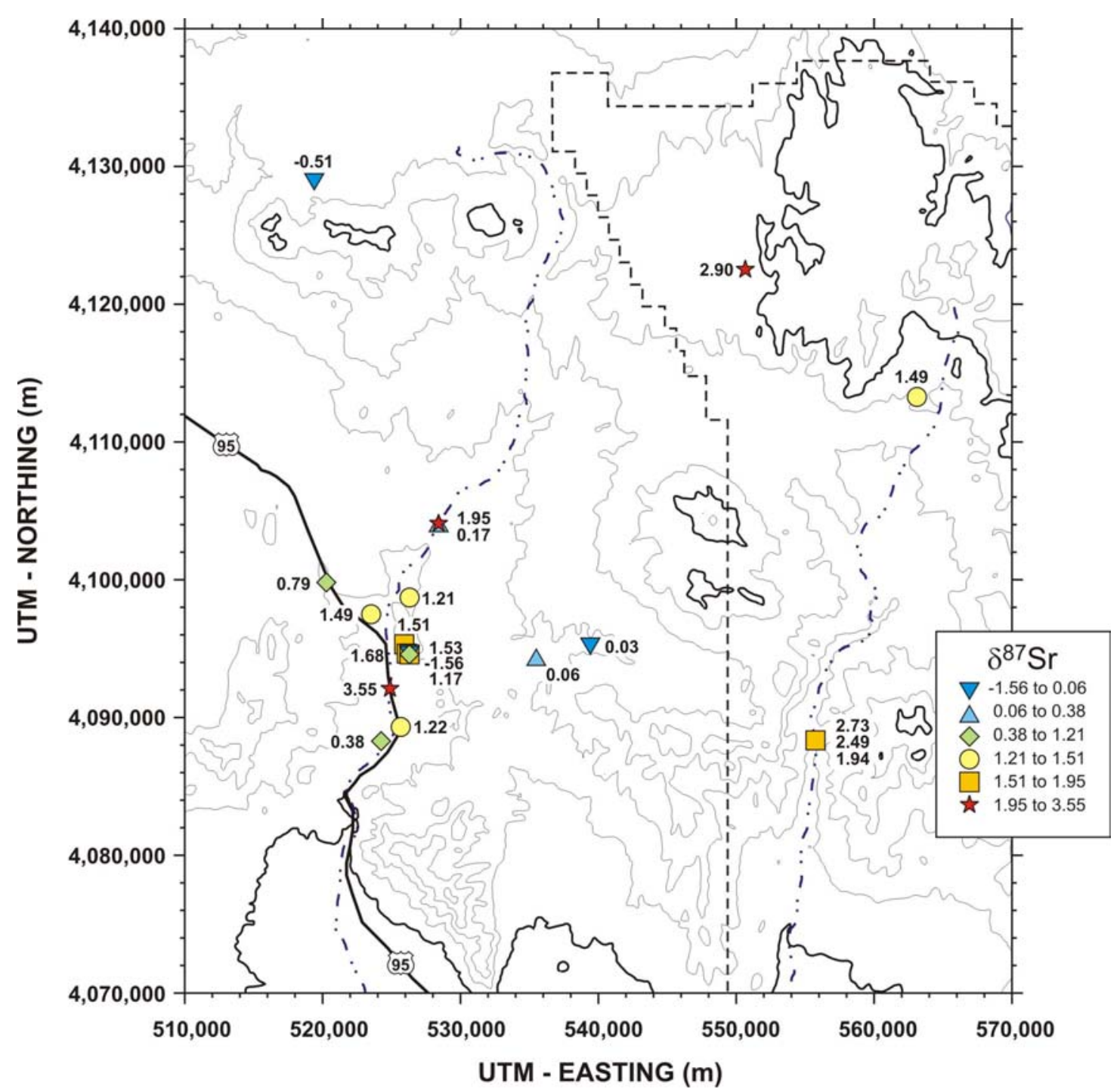

Figure 3-13. Strontium isotopic values of groundwater in the Pahute Mesa-Oasis Valley region.

Groundwater in western Oasis Valley is represented by only two samples with $\delta^{87} \mathrm{Sr}$ ratios of +0.79 from the westernmost borehole (ER-OV-5) and +1.49 (Springdale Well) from west of the Amargosa River, but in closer proximity to the central Oasis Valley group. The slightly less radiogenic (smaller $\delta^{87} \mathrm{Sr}$ values) and heavier $\delta \mathrm{D}$ and $\delta^{18} \mathrm{O}$ values for these two water samples support the likelihood of a distinct flowpath originating to the northwest. Groundwater from Tolicha Peak to the north has a small $\delta^{87} \mathrm{Sr}$ ratio of -0.51 and may be related to the same regional flow system as western Oasis Valley. Groundwater in Beatty Wash, near Timber Mountain (ER-OV-3c and Coffers Windmill) also has small $\delta^{87} \mathrm{Sr}$ values $(+0.06$ and +0.03$)$. If this groundwater flows parallel to the southwesterly trend of Beatty Wash, the nonradiogenic $\delta^{87} \mathrm{Sr}$ component may provide the component resulting in the smaller $\delta^{87} \mathrm{Sr}$ value observed in water from Frans Spring.

Groundwater from U-20 WW (Pahute Mesa) has a relatively high $\delta^{87} \mathrm{Sr}$ value of $+2.9 \%$. Similar values are observed for other wells on Pahute Mesa. For example, samples collected 
from the ER-20-6 well cluster in 1997 have $\delta^{87}$ Sr values between +2.55 and $+2.75 \%$ (Zell Peterman, USGS, unpublished data). Assuming a hydrologic connection between Pahute Mesa and central Oasis Valley, the general evolution toward lower $\delta^{87} \mathrm{Sr}$ values from Pahute Mesa to the southwest probably reflects silicate water-rock interaction with reactive volcanic rocks containing nonradiogenic strontium. The Ammonia Tanks Tuff, one of the main units comprising the Timber Mountain aquifer, has whole rock $\delta^{87} \mathrm{Sr}$ values between -1.6 and $-2.3 \%$. Hence, the relatively low $\delta^{87} \mathrm{Sr}$ values for these rocks may account for the observed ${ }^{87} \mathrm{Sr}$ depeletion in Oasis Valley groundwaters relative to Pahute Mesa groundwater. However, this interpretation is likely an oversimplification considering other geochemical results.

Groundwater sampled near the mouth of Thirsty Canyon (boreholes ER-OV-1 and ER-OV-6a) located between Pahute Mesa and Oasis Valley is not easily linked to U-20 WW and Oasis Valley groundwaters by progressive evolution. As noted previously, $\mathrm{Ca}$ and $\mathrm{Sr}$ concentrations in groundwater from these boreholes are substantially smaller than either Pahute Mesa or Oasis Valley groundwaters. Although $\mathrm{Ca}$ and $\mathrm{Sr}$ could be removed from U-20 WW groundwater by exchange with zeolites to obtain a composition like that of ER-OV-1 and -6a, both elements would have to then be added back to solutions to attain the larger values observed in the Oasis Valley discharge area.

\begin{tabular}{llccccc}
\hline \multicolumn{1}{c}{ Sample } & \multicolumn{1}{c}{ Location } & $\begin{array}{c}\mathrm{Ca} \\
(\mathrm{mg} / \mathrm{L})\end{array}$ & $\begin{array}{c}\mathrm{Sr} \\
(\mathrm{mg} / \mathrm{L})\end{array}$ & $\delta^{87} \mathrm{Sr}$ & $\begin{array}{c}\text { Calcite Saturation } \\
\text { Index }\end{array}$ & $\begin{array}{c}\text { Water Temperature } \\
\left({ }^{\circ} \mathrm{C}\right)\end{array}$ \\
\hline U-20 WW & Pahute Mesa & 7.8 & 0.026 & 2.90 & -0.17 & 37.2 \\
ER-OV-1 & Thirsty Canyon & 6.8 & 0.005 & 1.95 & -0.09 & 26.4 \\
ER-OV-6a & Thirsty Canyon & 2.3 & 0.011 & 0.17 & -0.51 & 29.2 \\
ER-OV-2 & Oasis Valley & 14.9 & 0.047 & 1.21 & +0.16 & 20.9 \\
Mullen Spr. & Oasis Valley & 16.7 & 0.086 & 1.51 & +0.05 & 21.0 \\
\hline
\end{tabular}

In addition, the two Thirsty Canyon samples collected from the same location but at different depths have large differences in their $\delta^{87} \mathrm{Sr}$ values. Shallow water from ER-OV-1 (open interval depth of 43 to $55 \mathrm{~m}$, Table 1 of Robledo et al., 1997) has a $\delta^{87} \mathrm{Sr}$ value of +1.95 , whereas deeper groundwater from ER-OV-6a (open interval 149 to $163 \mathrm{~m}$, Table 1 of Robledo et al., 1998) has a $\delta^{87} \mathrm{Sr}$ value of +0.17 . Although the $\delta^{87} \mathrm{Sr}$ value for the shallower water is intermediate between Pahute Mesa and Oasis Valley compositions, the deeper water has a $\delta^{87} \mathrm{Sr}$ value that is outside this range.

Strontium relations between groundwater samples in the Pahute Mesa - Thirsty Canyon Oasis Valley system do not follow simple patterns of chemical evolution. The limited data set implies that water/rock reactions within the volcanic aquifer are important, but that contributions from a calcite source are also necessary. These contributions could be in the form of reaction with calcite formed previously on flowpath surfaces, additions of calcite-saturated recharge in the Oasis Valley discharge area, or mixing of Ca-rich groundwater leaking from the carbonate aquifer. With the exception of Baileys Hot Spring, cooler groundwater temperatures in the Oasis Valley favor input from a surface source rather than deep source of calcite-saturated water. As previously noted, the increased ${ }^{14} \mathrm{C}$ content of the Oasis Valley groundwater (e.g., Figure 3-4) implies either dissolution of young soil zone carbonate minerals, or small amounts of mixing with young, local recharge that is saturated with respect to calcite. The latter process is 
permissible in the context of the $\delta \mathrm{D}$ and $\delta^{18} \mathrm{O}$ results illustrated in Figure 3-3. However, the absence of tritium in samples from the Oasis Valley discharge area suggests that mixing with local recharge must occur at some point upgradient of the discharge zone.

\subsubsection{Uranium Isotopes}

Uranium-234 is an intermediate decay product of uranium-238, which, if undisturbed, reaches a state of secular equilibrium in solid materials older than several million years (i.e., the activity of the daughter product is equal to that of the parent such that the ${ }^{234} \mathrm{U} /{ }^{238} \mathrm{U}$ activity ratio $=1.0$ ). In contrast, oxygenated groundwater in southern Nevada has ${ }^{234} \mathrm{U} /{ }^{238} \mathrm{U}$ ratios that are commonly greater than those in surface runoff $\left({ }^{234} \mathrm{U} /{ }^{238} \mathrm{U}\right.$ activity ratios commonly between 1.5 and 2.0) or soil-zone materials (initial ${ }^{234} \mathrm{U} /{ }^{238} \mathrm{U}$ activity ratios of 1.3 to 2.0 ). Elevated ${ }^{234} \mathrm{U} /{ }^{238} \mathrm{U}$ signatures in groundwater are obtained by preferential incorporation of ${ }^{234} \mathrm{U}$ relative to ${ }^{238} \mathrm{U}$ along flowpaths due to processes related to the effects of radioactive decay in the adjacent wall rock. The dominant mechanisms are preferential leaching of ${ }^{234} \mathrm{U}$ from radiation-damaged lattice sites (Szilard-Chalmers effects), radiation induced oxidation of ${ }^{234} U$ leading to a more soluble uranyl $\left(\mathrm{U}^{+6}\right)$ ion, and $\alpha$-recoil of thorium-234 $\left({ }^{234 \mathrm{Th}}\right)$ from crystal surfaces. The amount of ${ }^{234} \mathrm{U}$ excess relative to ${ }^{238} \mathrm{U}$ is limited by rates of ${ }^{234} \mathrm{U}$ decay, water-rock ratios, flowpath length, and the amount of bulk-rock dissolution from the aquifer. These factors typically result in ${ }^{234} \mathrm{U} /{ }^{238} \mathrm{U}$ activity ratios between about 2 and 4 in most southern Nevada groundwaters (Ludwig et al., 1993).

Uranium concentrations in groundwater samples collected during this study range from 0.4 to $18.3 \mu \mathrm{g} / \mathrm{L}$ (Figure 3-14; data in Appendix B). In the central Oasis Valley discharge zone, uranium concentrations range from 3 to $18 \mu \mathrm{g} / \mathrm{L}$, with many samples in the 9 to $10 \mu \mathrm{g} / \mathrm{L}$ range. These values are anomalously high relative to most groundwaters in the region, which typically vary from 0.5 to $3 \mu \mathrm{g} / \mathrm{L}$. Groundwater from western Oasis Valley tends to have lower concentrations ( 2.2 to $2.6 \mu \mathrm{g} / \mathrm{L}$ ), and samples from Beatty Wash have intermediate values (4.2 to $5.5 \mu \mathrm{g} / \mathrm{L})$. U-20 WW has a uranium concentration of $2.3 \mu \mathrm{g} / \mathrm{L}$, which is lower than most Oasis Valley samples, but larger than WW-8 $(0.4 \mu \mathrm{g} / \mathrm{L}), \mathrm{UE}-29 \mathrm{a} \# 1$ and \#2 (0.7 and $1.5 \mu \mathrm{g} / \mathrm{L})$, and most Yucca Mountain groundwaters. However, uranium concentrations in groundwaters previously sampled on Pahute Mesa range as high as 15 to $19 \mu \mathrm{g} / \mathrm{L}$ in well ER-20-5 \#1 (two independent samples analyzed at LLNL and USGS laboratories; Rose et al., 1997; J.B. Paces, U.S. Geological Survey, unpublished data) implying considerable variability in the uranium content of the tuffaceous rocks comprising the Pahute Mesa aquifers. (Note: Although ER-20-5 \#1 is situated in close proximity to an underground nuclear test cavity, the groundwater ${ }^{235} \mathrm{U} /{ }^{238} \mathrm{U}$ ratio indicates the uranium is of natural origin).

A positive correlation between uranium and sodium concentrations (Figure 3-15) is likely related to water-rock interaction with felsic volcanic rocks. Groundwater from ER-OV-2 and Baileys Hot Spring would have undergone the greatest amount of water-rock interaction based on this premise. These two samples also contain the largest ${ }^{3} \mathrm{He} /{ }^{4} \mathrm{He}$ ratios measured in this study (Figure 3-8), indicating the greatest component of mantle-derived helium associated with deeply circulating groundwater or mixtures with fluids ascending along a deep fault zone. The greater degree of water/rock interaction along these flowpaths might be expected to result in larger $\mathrm{U}$ and $\mathrm{Na}$ contents. Both of the Thirsty Canyon samples (ER-OV-1 and ER-OV-6a) contain elevated Na contents with respect to Pahute Mesa and Oasis Valley groundwaters. The large $\mathrm{Na}$ contents in these samples, along with their small Ca contents noted previously (section 3.2.7), are 


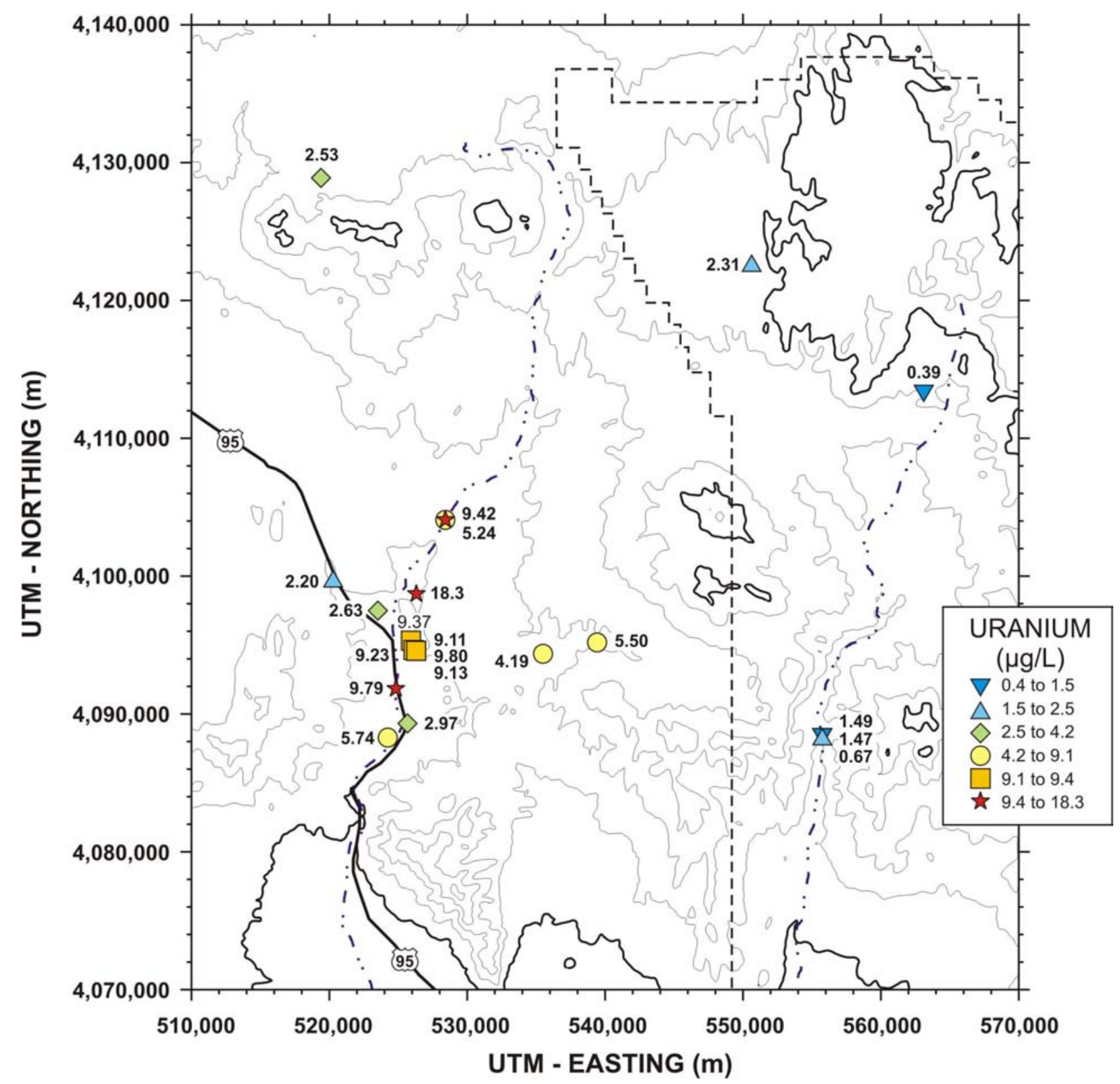

Figure 3-14. Uranium concentrations in groundwater in the Pahute Mesa-Oasis Valley region.

consistent with ion exchange processes involving zeolitized volcanic rock along the flowpath. As with $\mathrm{Ca}$ and $\mathrm{Sr}$, the $\mathrm{Na}$ and $\mathrm{U}$ compositions of these waters are not intermediate between U-20 WW (Pahute Mesa) and the central Oasis Valley data cluster (Figure 3-15), implying that chemical changes along this possible flowpath are more complex than simple progressive evolution or mixing (see section 3.2.7). However, it should be emphasized that groundwater from different stratigraphic units on Pahute Mesa can exhibit large variations in groundwater chemistry. U-20 WW is not representative of all Pahute Mesa groundwater. The ER-20-6 well cluster, about a kilometer to the northeast has uranium concentrations of 2.5 to $3.0 \mu \mathrm{g} / \mathrm{L}$ and Na${ }^{+}$ of about $60 \mathrm{mg} / \mathrm{L}$, whereas the ER-20-5 \#1 well, about 5 kilometers to the southwest has much larger uranium concentrations of 15 to 19 as well as larger $\mathrm{Na}^{+}$contents $(110 \mathrm{mg} / \mathrm{L})$. The compositional variability in Pahute Mesa groundwater and the extent to which the various groundwaters from different stratigraphic intervals mix along the flowpath to Oasis Valley is 
poorly constrained. Nonuniform flow and vertical mixing processes are certainly possible in these types of fracture-dominated flow systems.

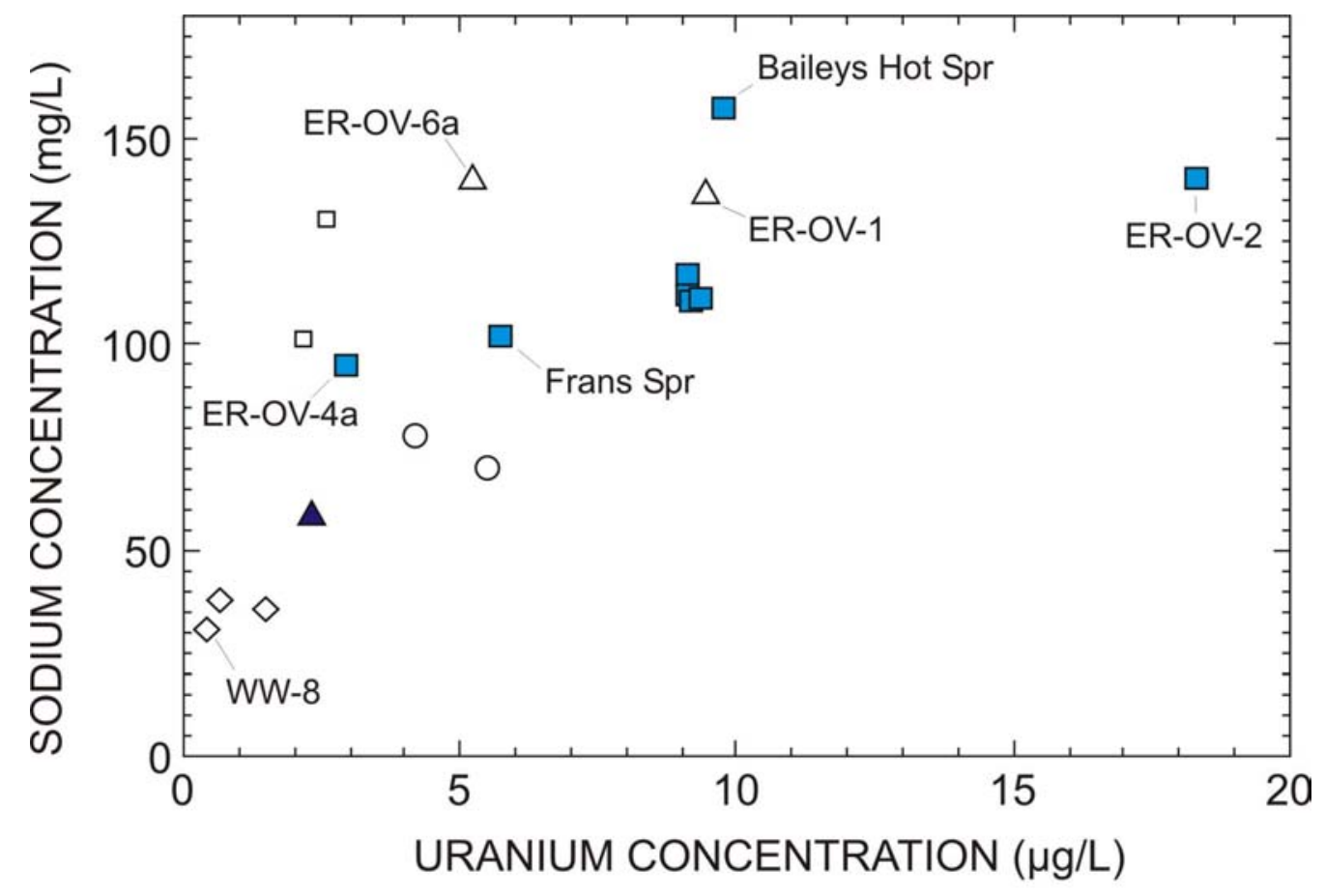

\section{EXPLANATION}

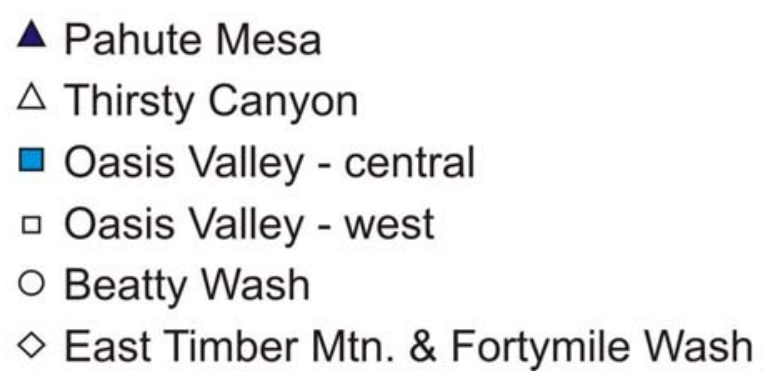

Figure 3-15. Comparison of sodium and uranium concentrations in groundwater in the Pahute MesaOasis Valley region.

The ${ }^{234} \mathrm{U} /{ }^{238} \mathrm{U}$ activity ratios in groundwaters sampled from the study area span a range from 2.5 to 5.4 (Figure 3-16). Groundwater from central Oasis Valley has ${ }^{234} \mathrm{U} /{ }^{238} \mathrm{U}$ activity ratios ranging from 2.5 to 3, with most values between 2.9 and 3.0. Groundwater from ER-OV-5 in western Oasis Valley data has a similar ${ }^{234} \mathrm{U} /{ }^{238} \mathrm{U}$ activity ratio of 2.8; however, water from Springdale Well has an anomalously large value of 5.4. Larger values of ${ }^{234} \mathrm{U} /{ }^{238} \mathrm{U}$ activity between 4.1 and 5.4 are also observed in U-20 WW, Beatty Wash and Tolicha Peak samples and are similar to the range commonly observed for NTS volcanic aquifers. Thirsty Canyon samples (ER-OV-1 and ER-OV-6a) have values that are intermediate between U-20 WW and central Oasis Valley. Groundwater along this potential flowpath shows an evolution from large ${ }^{234} \mathrm{U} /{ }^{238} \mathrm{U}$ activities and small concentrations at Pahute Mesa to smaller ${ }^{234} \mathrm{U} /{ }^{238} \mathrm{U}$ activities and 


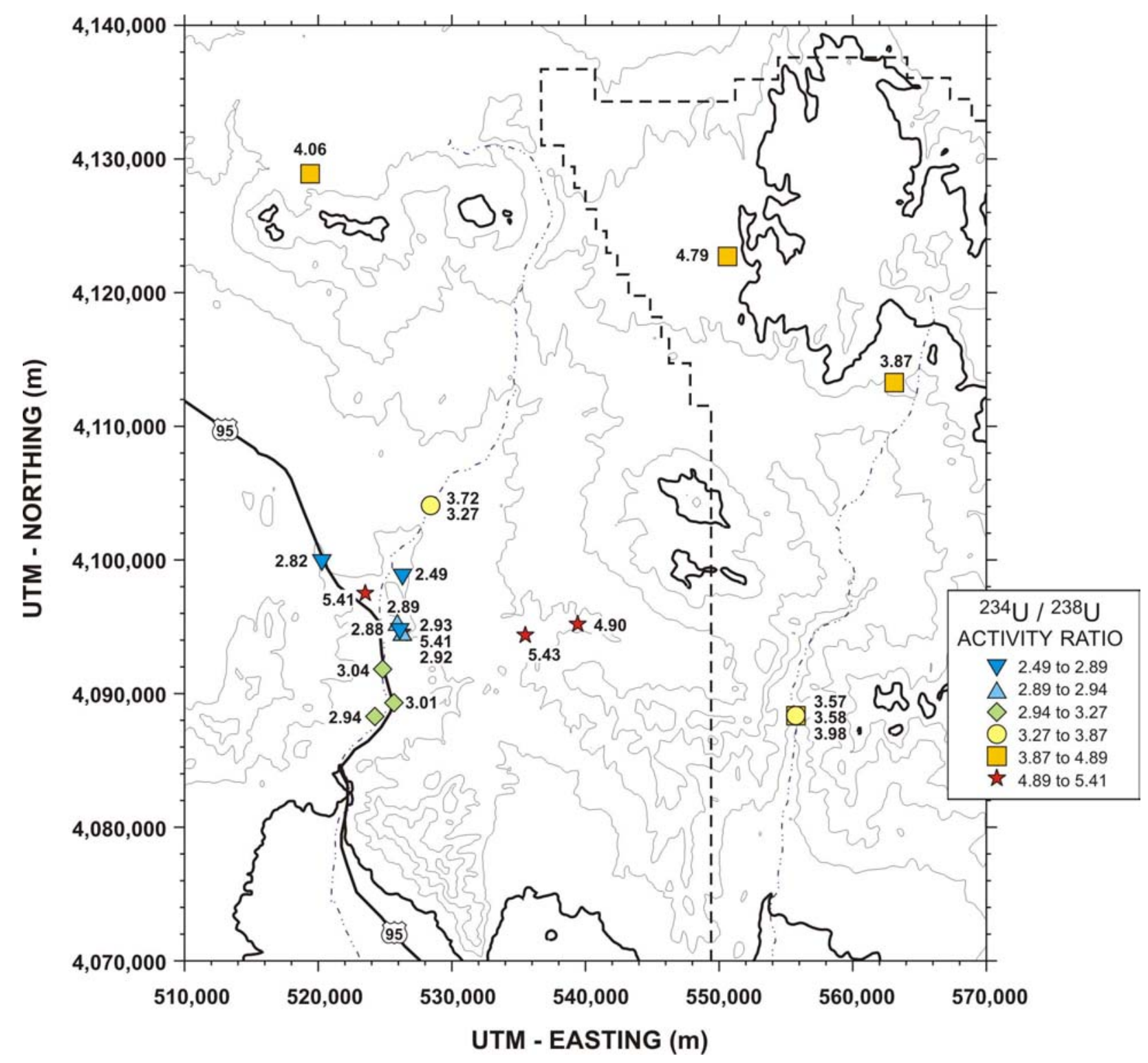

Figure 3-16. Uranium activity ratios in groundwater in the Pahute Mesa-Oasis Valley region.

larger concentrations in Oasis Valley discharge (Figure 3-17). This negative correlation between uranium concentration and ${ }^{234} \mathrm{U} /{ }^{238} \mathrm{U}$ activity ratios is related to increasing amounts of bulk dissolution of uranium in rocks containing ${ }^{234} \mathrm{U}$ in secular equilibrium. The intermediate compositions of the Thirsty Canyon groundwaters lie at reasonable positions along this trend, implying that $U$ in groundwater is not likely affected by the water/rock interaction with zeolites affecting alkali and alkali-earth elements.

\subsection{Summary}

The geochemical data presented in this chapter provide a consistent framework for the interpretation of the Pahute Mesa-Oasis Valley groundwater flow system. Several independent lines of evidence suggest a direct hydrologic connection between the underground testing area in western Pahute Mesa and the groundwater discharge area in Oasis Valley. In particular, 


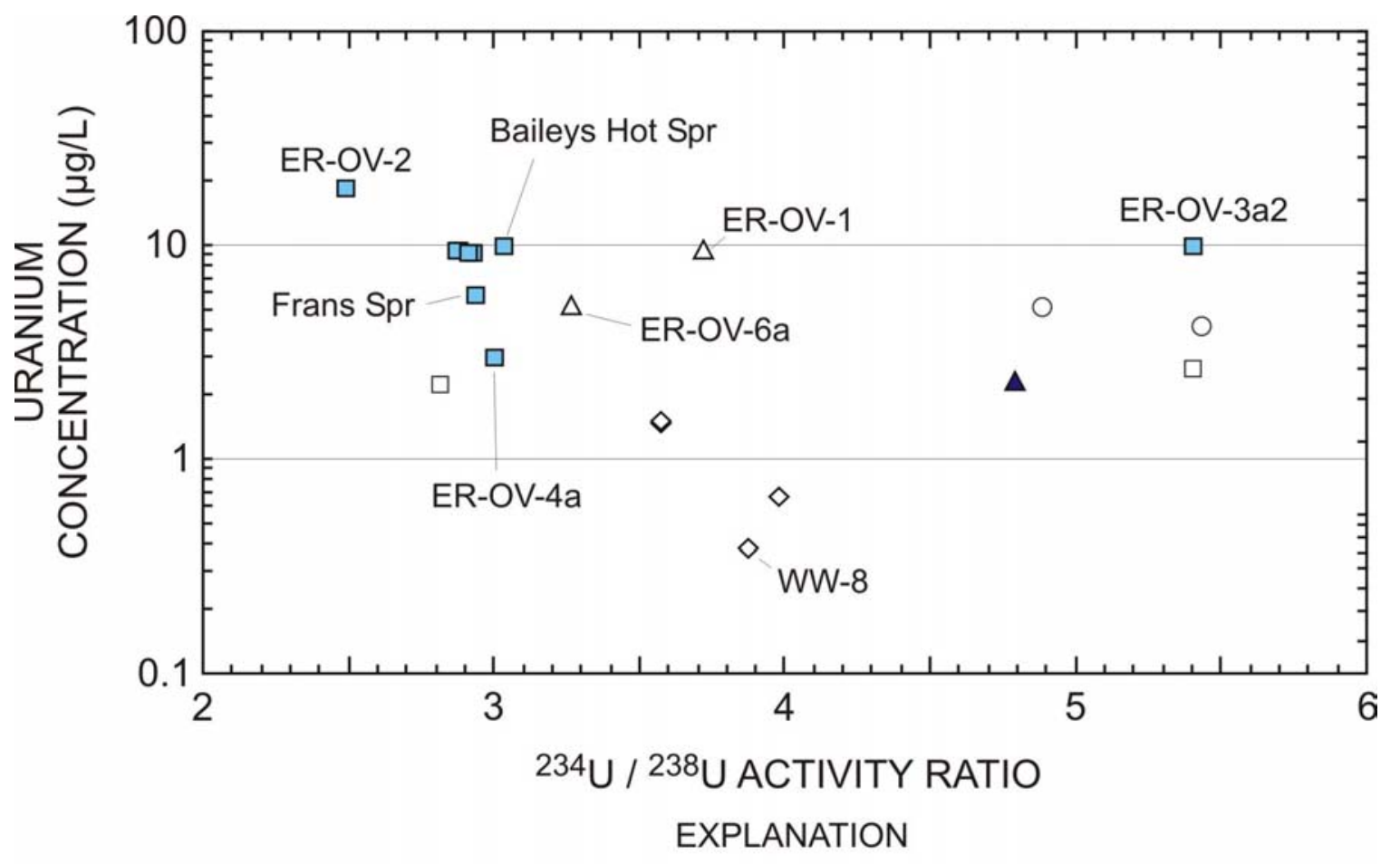
$\Delta$ Pahute Mesa
$\triangle$ Thirsty Canyon
Oasis Valley - central
$\square$ Oasis Valley - west
Beatty Wash
$\diamond$ East Timber Mtn. \& Fortymile Wash

Figure 3-17. Comparison of uranium concentrations and activity ratios in groundwater in the Pahute Mesa-Oasis Valley region.

hydrogen and oxygen stable isotope data indicate that central Oasis Valley groundwater is largely derived from Pahute Mesa regional underflow, but may also contain a small mixing component of isotopically heavy local recharge. Examination of stable isotope patterns over a broader region failed to reveal a likely alternative source for the Oasis Valley groundwater, although sample coverage is admittedly poor in some key areas (e.g., Cactus Flat and Gold Flat).

Groundwater ${ }^{14} \mathrm{C}$ data indicate long aquifer residence times, and reveal the importance of water-rock interaction with calcite in controlling the carbon isotope geochemistry of the waters. Groundwater ${ }^{14} \mathrm{C}$ contents actually increase between Pahute Mesa and Oasis Valley, implying mixing with a young recharge component, and/or open system reactions with soil $\mathrm{CO}_{2}$ and young soil carbonate minerals in the Oasis Valley discharge area. This increase in ${ }^{14} \mathrm{C}$ apparent ages between Pahute Mesa and Oasis Valley makes it difficult to assign travel times to the flow system.

Tritium was not observed in a majority of the groundwaters collected during this study, indicating that most of the samples do not contain a significant component of young water $(<50$ years old). Relatively high tritium concentrations were observed only in the UE-29a wells in Fortymile Wash, which have ${ }^{3} \mathrm{H}-{ }^{3} \mathrm{He}$ ages of less than 10 years. Other geochemical parameters 
(e.g., stable isotopes, ${ }^{14} \mathrm{C}$, and CFCs) clearly indicate a young, local source for the UE-29a groundwaters.

The helium isotope data indicate long groundwater residence times, in accord with the ${ }^{14} \mathrm{C}$ results, and reveal a strong component of mantle-derived ${ }^{3} \mathrm{He}$ in many of the Oasis Valley groundwaters. This implies that major structural features, such as the Thirsty Canyon lineament, may have roots extending to the deep crust or upper mantle, thereby providing a conduit for the transmission of deep gases. The notably high ${ }^{3} \mathrm{He} /{ }^{4} \mathrm{He}$ ratio at Baileys Hot Spring implies the deep circulation of meteoric water - an interpretation that is consistent with the elevated $\delta^{87} \mathrm{Sr}$ and trace element abundances for this spring.

Chlorofluorocarbons (CFCs) were observed in all of the wells and springs sampled during this study. However, in many cases, the CFCs are interpreted to have been introduced during well development, or during sampling. In the natural discharge areas of Oasis Valley, CFCs are observed in the groundwater, but tritium is not, implying that atmospheric gases diffuse through the unsaturated zone to the water table at locations upgradient from the spring sites. This is consistent with the open system processes inferred on the basis of carbon isotopic evidence.

Statistical analysis of the trace element data indicates that the Pahute Mesa and Oasis Valley groundwaters have distinct trace element chemistries. However, principal components analysis revealed an increasing concentration gradient for conservative trace elements between Pahute Mesa and Oasis Valley that closely parallels potentiometric contours beneath Pahute Mesa defined by Blankennagel and Weir (1973). This implies an evolution in the trace element geochemistry, controlled by water-rock interaction along the flowpath, the dissolved oxygen content of the groundwater, and evapotranspiration processes in the discharge area.

Strontium isotope values and $\mathrm{Ca} / \mathrm{Sr}$ ratios in groundwater are predominantly influenced by silicate water-rock interaction. $\delta^{87} \mathrm{Sr}$ values generally decrease going from Pahute Mesa to Oasis Valley, reflecting interaction with low $\delta^{87} \mathrm{Sr}$ volcanic rocks. However, the chemistry of groundwater from wells located between Pahute Mesa and Oasis Valley is not consistent with a simple pattern of chemical evolution. Comparison of different data components suggests a complex evolutionary pathway, involving multi-step, water-rock interaction with both silicate rocks and calcite, cation exchange between water and zeolitic aquifer rock, open system reactions in the discharge area, and possible mixing with a young recharge component.

Uranium concentrations are anomalously high in Oasis Valley groundwaters as compared to most regional groundwaters in southern Nevada. A positive correlation between groundwater uranium and sodium concentrations indicates water-rock interaction with felsic volcanic rocks, which are the probable source of the high uranium concentrations. The elevated groundwater ${ }^{234} \mathrm{U} /{ }^{238} \mathrm{U}$ activity ratios observed in upgradient areas (Pahute Mesa, Beatty Wash and Tolicha Peak) are typical of groundwaters in the volcanic aquifers of the NTS, reflecting the preferential incorporation of ${ }^{234} \mathrm{U}$ from the aquifer rock matrix. As water flows into the Oasis Valley discharge area, uranium contents increase and ${ }^{234} \mathrm{U} /{ }^{238} \mathrm{U}$ activity ratios decrease, reflecting an increasing degree of water/rock interaction including a larger component of bulk uranium derived from rock containing ${ }^{234} \mathrm{U}^{238} \mathrm{U}$ in secular equilibrium. 


\section{CHAPTER 4 \\ GEOCHEMICAL EVALUATION OF SOURCES, FLOWPATHS, AND TRAVEL TIMES OF GROUNDWATER FLOW TO OASIS VALLEY, NEVADA}

\subsection{Introduction}

The sources and travel times of groundwater flow to Oasis Valley were evaluated for potential flowpaths identified by groundwater flow modeling studies and by isotopic and geochemical data in the previous chapters of this report (see Chapter 1, Figure 1-1). The flowpaths are (1) Pahute Mesa groundwater to Oasis Valley; (2) groundwater north of Oasis Valley mixing with Pahute Mesa groundwater to Oasis Valley; (3) groundwater north of Oasis Valley to northwest Oasis Valley (Springdale area); (4) Pahute Mesa groundwater to south of Timber Mountain through the Beatty Wash area to Oasis Valley; and (5) Pahute Mesa groundwater down Fortymile Canyon. A variation of flowpath (1) is also included for mixing of recharge on Pahute Mesa with Pahute Mesa groundwater that flows to Oasis Valley. This flowpath is included as flowpath (1b). Another variation of flowpath (1) is included for Pahute Mesa groundwater mixing with shallow groundwater in Oasis Valley that has undergone exchange with atmospheric gases. This flowpath is included as flowpath (1c).

The geochemical mass-balance models developed for this study are based on the groundwater, and solid-phase (see Chapter 1) and gas-phase chemical and isotopic compositions measured for this study and from previous studies. Geochemical mass-balance models do not have unique solutions, rather solutions are only constrained by changes in water chemistry along a flowpath and by the number, and chemical and isotopic compositions, of phases included in the model. The geochemical modeling presented in this chapter is limited by our current knowledge of groundwater, and solid-phase and gas-phase chemistry. Other solutions are possible, depending on the phases chosen for the models and the chemical and isotopic composition of those phases.

\subsection{Analytical Methods}

Methods for collection, processing, and analysis of groundwater samples for major-ions, trace elements, and isotopes have been discussed earlier in this report and will not be reiterated here, with the exception of DOC carbon isotope collection, sample preparation, and analytical techniques. Water samples for analysis of DOC isotopes were collected with submersible pumps using specialized sampling equipment that isolates water samples from potential organic carbon sources. The samples were filtered through a 0.45 -micron silver-membrane filter and collected in amber glass bottles that had been cleaned and then baked at $350^{\circ} \mathrm{C}$ to combust any organic carbon. DIC was driven from the water sample by adding phosphoric acid and then gas stripping the water sample by applying a vacuum to the sample. The removal of DIC is critical to DOC analysis, because any DIC would be included in the DOC analysis if not removed. The water sample was then evaporated to ash by using a vacuum evaporator pump, keeping the sample isolated from atmospheric gases, while heating to $50^{\circ} \mathrm{C}$. The ash was combusted, and $\mathrm{CO}_{2}$ gas was collected and analyzed for ${ }^{13} \mathrm{C}$ by standard mass spectrometry techniques. Then the $\mathrm{CO}_{2}$ gas was made into graphite targets and analyzed on a tandem accelerator to obtain a ${ }^{14} \mathrm{C}$ value. 


\subsection{Water-rock Interactions}

To be a valid flowpath, the observed water chemistry at the end of a flowpath has to have evolved along a proposed flowpath by reacting with identified minerals and gas phases, or have resulted from proportional mixing of chemically different waters. If the changes in water chemistry along a flowpath cannot be explained by thermodynamically feasible mass-balance reactions, or by mixing, then the flowpath is not a valid flowpath. This approach is limited by the available mineral and gas chemical and isotopic data. Thus, additional or different mineral phase and gas data may result in model solutions different from those obtained with our current database.

\subsubsection{Mineral-phase Chemistry}

The chemical and isotopic compositions of solid and gas phases identified in the aquifers are described in Chapter 1 of this report and are presented in Tables 1-3 and 1-4. These phases along with standard mineral and gas phases, which are defined in the computer code NETPATH (Plummer et al., 1994), were used in the geochemical models. The chemical compositions of clay, glass, feldspar, and zeolite used in the modeling are the average composition of these phases measured for samples from each aquifer unit (Chapter 1, Table 1-3). In the geochemical models, for flowpaths with water flowing through more than one aquifer unit, the average chemical composition of the phases for each unit is used to obtain an average chemical composition of the phase.

\subsubsection{Geochemical Modeling}

Potential groundwater flowpaths were explored with geochemical models, which were developed by using chemical and isotopic groundwater, mineralogic, and gas data. These data include those collected for this study and historical data (Appendices A and B). The data are limited to the Pahute Mesa area of the NTS, the Oasis Valley area, and areas to the north. The models are an extension of the geochemical modeling conducted by White (1979) and White and Chuma (1987) for Oasis Valley and by Claassen and White (1979) and White et al. (1980) for Rainier Mesa. The models are limited to observed aqueous, solid-, and gas-phase chemistry on Pahute Mesa, aqueous chemistry in Oasis Valley and sites to the north of the Oasis ValleyPahute Mesa area, and $\mathrm{CO}_{2}$ gas isotopic data from Yucca Mountain (Thorstenson et al., 1998). Thus, inferences are made for groundwater flowpaths across large areas in which no aqueous, solid-phase, or gas data exist. Geochemical model interpretations are also limited by the lack of chemically and isotopically complete samples from sites north of the Pahute Mesa-Oasis Valley area, which may be a major source of groundwater for Pahute Mesa and Oasis Valley.

Using water and solid-phase chemistries for samples collected for this study, and historical data where available (White, 1979; White and Chuma, 1987; Warren et al., 1998), geochemical models were developed to determine whether the proposed flowpaths and mixtures of waters are geochemically and isotopically feasible and thermodynamically plausible. Models were developed for proposed flowpaths, and mixtures of water, assuming that groundwater is flowing through all aquifers between the initial and final well(s) or spring(s) along a flowpath.

Groundwater in the Oasis Valley area discharges from the Timber Mountain aquifer, although it often flows from the Timber Mountain aquifer through basin-fill sediments before discharging. Thus, if a sample is from a well completed in, or a spring discharging from, the Paintbrush, Belted Range, or Basal aquifers, the average solid-phase chemistries of volcanic glass, feldspars, clay minerals, and zeolites for these aquifer units were used in the model. For example, WW-8 
is completed in the Belted Range Aquifer, so a model for a flowpath from WW-8 to Oasis Valley uses solid-phase chemistry that is the average of the three aquifer units (Belted Range, Paintbrush, and Timber Mountain aquifers) that the groundwater most likely flows through before discharging in Oasis Valley (Appendix A; Chapter 1, Table 1-3). The solid-phase chemistries for volcanic glass, feldspars, clay minerals, and zeolites for the different aquifers are discussed in Chapter 1. Geochemical models that describe plausible geochemical reactions along a flowpath, and in some cases also include mixing of different waters, were developed using the computer code NETPATH (Plummer et al., 1994).

Geochemical modeling results for proposed flowpaths are presented in Table 4-1 (Geochemical mass balance models for proposed flowpaths. - located in back of this report). Feasible geochemical reactions that can explain the changes in water chemistry along proposed flowpaths include dissolution/precipitation of calcite; dissolution of $\mathrm{NaCl}$, volcanic glass, feldspar, and pyrite; formation of an $\mathrm{SiO}_{2}$ phase, clay, zeolite, and K-feldspar; exchange of calcium and magnesium in groundwater for sodium on clays or zeolites; analcime dissolution or formation; calcite exchange (dissolution and precipitation); and $\mathrm{CO}_{2}$ gas dissolution or exsolution. Some of the models also include mixing of two waters in addition to the geochemical reactions. The number of phases included in a model solution is limited by the number constraints (elements) of the model. Thus, not all possible phases can be included in any one model. Additionally, the substitution of one phase for another in the model may result in the mass transfers of the other phases being similar in both models. For example, a model that includes volcanic glass dissolution, which generally is a large source of most major-ions and silica, is likely to be similar to a model that includes feldspar dissolution, which also would generally be a large source of most major-ions and silica. Constraints on the mass-transfer models were set at: (1) a maximum mass-transfer of 5.0 millimoles (mmoles) of a mineral per $\mathrm{kg}$ of water (which in these waters is equivalent to a liter) and (2) 0.20 mmole of $\mathrm{CO}_{2}$ gas per $\mathrm{kg}$ of water entering or leaving a water along a flowpath, except for springs at the end of a flowpath where no limit was placed on the exsolution of $\mathrm{CO}_{2}$ gas from the spring water. A closed system with little exchange of $\mathrm{CO}_{2}$ gas between unsaturated zone $\mathrm{CO}_{2}$ gas and the groundwater was assumed in the modeling. Another constraint imposed on the geochemical models was that in the case of mixing groundwaters, the $\delta^{18} \mathrm{O}$ value of the mixture of waters had to be within \pm $0.5 \%$ of the end member water. This limit was set to account for analytical uncertainty $( \pm$ $0.15 \%$ ) and the variability in $\delta^{18} \mathrm{O}$ values at a site over time. The geochemical reactions included in our modeling are similar to the ones described by White (1979) and White and Chuma (1987) to explain the chemical composition and chemical evolution of groundwater in the Oasis Valley area.

On the basis of mineralogic observations of cores from Pahute Mesa (Chapter 1) and thermodynamic calculations in NETPATH (Table 4-2) some of the phases in the models were set to either only dissolve or precipitate. The phases that were constrained to only dissolve were $\mathrm{NaCl}$, pyrite, volcanic glass, and primary alkali feldspar. The phases that were limited to only precipitation or formation by incongruent dissolution, were $\mathrm{SiO}_{2}$, secondary K-feldspar, clay, and zeolite. Ion exchange of $\mathrm{Ca}$ and $\mathrm{Mg}$ for $\mathrm{Na}$ was constrained to only allow for exchange of $\mathrm{Ca}$ and $\mathrm{Mg}$ in the water for $\mathrm{Na}$ on clays and zeolites. Calcite, analcime, and $\mathrm{CO}_{2}$ gas were allowed to dissolve or precipitate (or in the case of $\mathrm{CO}_{2}$ gas, exsolve) in the model. 
Table 4-2. Results of thermodynamic speciation calculations from NETPATH. Values are saturation indices: negative values indicate undersaturation, positive values indicate oversaturation.

\begin{tabular}{|c|c|c|c|c|c|c|c|}
\hline Site Name & Calcite & $\begin{array}{c}\mathrm{SiO}_{2} \\
\text { (Chalcedony) }\end{array}$ & Albite & Anorthite & K-feldspar & Ca-smectite & Illite \\
\hline ER-OV-01 Well & -0.09 & 0.59 & 0.97 & -1.88 & 2.01 & 3.15 & 2.72 \\
\hline ER-OV-02 Well & 0.16 & 0.57 & 0.31 & -3.10 & 1.34 & 2.07 & 1.65 \\
\hline ER-OV-03a Well & -0.01 & 0.54 & 0.59 & -2.10 & 1.66 & 3.25 & 2.77 \\
\hline ER-OV-03a2 Well & 0.36 & 0.05 & 0.86 & -1.23 & 2.67 & 2.28 & 3.44 \\
\hline ER-OV-03a3 Well & 0.13 & 0.56 & 0.54 & -2.46 & 1.64 & 2.71 & 2.39 \\
\hline ER-OV-03c Well & 0.18 & 0.37 & -0.54 & -3.05 & 0.04 & 1.17 & 0.40 \\
\hline ER-OV-04a Well & 0.09 & 0.60 & 0.30 & -2.89 & 1.60 & 1.82 & 1.50 \\
\hline ER-OV-05 Well & -0.06 & 0.72 & 0.70 & -2.39 & 2.09 & 3.73 & 3.24 \\
\hline ER-OV-06a Well & -0.51 & 0.43 & 0.67 & -2.21 & 1.70 & 2.81 & 2.70 \\
\hline Coffers Windmill Well & 0.27 & 0.38 & -0.94 & -3.92 & -0.39 & 0.45 & -0.51 \\
\hline U-20 WW Well & -0.17 & 0.31 & -0.95 & -3.23 & -0.31 & 0.38 & -0.30 \\
\hline WW-8 Well & -1.29 & 0.49 & -0.94 & -3.98 & 0.48 & 2.71 & 1.56 \\
\hline UE-29a \#1 Well & -0.63 & 0.56 & -0.47 & -3.26 & 0.99 & 2.95 & 2.08 \\
\hline UE-29a \#2 Well & -0.31 & 0.39 & -1.12 & -4.07 & 0.19 & 1.06 & 0.47 \\
\hline Tolicha Peak Well & 0.24 & 0.46 & -1.07 & -3.77 & 0.20 & 0.08 & -0.29 \\
\hline Sdale Up Well & 0.10 & 0.55 & 0.03 & -2.83 & 1.16 & 2.29 & 1.81 \\
\hline Mullen Spring & 0.05 & 0.51 & 0.05 & -3.02 & 1.12 & 2.12 & 1.64 \\
\hline Baileys Hot Spring & -0.03 & 0.40 & -0.71 & -3.49 & 0.17 & 0.63 & -0.02 \\
\hline Frans (Angels) Spring & 0.03 & 0.37 & -0.74 & -3.66 & 0.40 & 0.06 & -0.28 \\
\hline Goss Spring & 0.13 & 0.52 & -0.20 & -3.55 & 0.87 & 1.28 & 0.91 \\
\hline UE-19h Well & 0.30 & 0.46 & 0.38 & -1.41 & 1.48 & 2.91 & 2.62 \\
\hline ER-20-6\#3 Well & 0.07 & 0.42 & 0.22 & -1.67 & 1.34 & 2.60 & 2.31 \\
\hline UE-18r Well & 0.21 & 0.35 & -1.80 & -5.22 & -1.10 & -1.48 & -2.26 \\
\hline ER-30-1\#1 Well & 0.03 & 0.12 & -2.35 & -6.55 & -1.85 & -4.02 & -4.13 \\
\hline Roller Coaster Well & -0.22 & 075 & -0.48 & -4.25 & 0.94 & 1.08 & 0.51 \\
\hline UE-20bh-1 Well & -0.30 & 0.54 & 0.03 & -3.50 & 1.36 & 1.52 & 1.42 \\
\hline Test Well 1 & -0.57 & 0.00 & -2.83 & -6.95 & -2.52 & -3.70 & -4.47 \\
\hline UE-19c Well & -1.76 & 0.26 & -2.49 & -6.37 & -2.41 & -1.74 & -3.29 \\
\hline Cedar Creek Pass Well & -0.34 & 0.71 & -0.93 & -4.33 & 0.81 & 0.94 & 0.24 \\
\hline U-20a\#2 Well & -0.11 & 0.31 & -2.16 & -5.71 & -1.42 & -2.84 & -3.29 \\
\hline Revert Spring & -0.26 & 0.51 & -1.04 & -5.09 & -0.05 & -0.25 & -0.69 \\
\hline Rose Spring & 0.24 & 0.42 & -1.44 & -4.38 & -0.38 & 1.51 & 0.36 \\
\hline Sandia 6B Well & 0.11 & 0.62 & -0.60 & -5.58 & 0.50 & -1.89 & -1.90 \\
\hline Silverbow Spring & -0.31 & 0.60 & -1.06 & -4.28 & -0.02 & 2.09 & 0.78 \\
\hline Sumner Spring & 0.35 & 0.48 & -1.19 & -4.32 & 0.10 & 1.28 & 0.50 \\
\hline J-12 Well & -0.75 & 0.48 & -1.55 & -4.97 & -0.11 & 0.76 & -0.13 \\
\hline J-13 Well & -0.74 & 0.46 & -1.68 & -5.09 & -0.34 & 0.28 & -0.57 \\
\hline
\end{tabular}




\subsubsection{Flowpath 1}

Models for proposed flowpath 1, Pahute Mesa groundwater to Oasis Valley, were developed for five sites on Pahute Mesa that have complete chemical and isotopic analyses (wells U-20 Water Well (U-20 WW), UE-20bh\#1, ER-20-6\#3, UE-19c, and UE-19h). The average chemical and isotopic compositions for these five sites were also included as a sixth model (average Pahute Mesa groundwater).

Geochemical modeling indicates that groundwater flow from Pahute Mesa to Oasis Valley is geochemically feasible for some flowpaths. However, not all five of the groundwater sites on Pahute Mesa, average of the five Pahute Mesa groundwaters, or groundwaters discharging from Oasis Valley have valid models (Table 4-1). The majority of the potential flowpaths for sites on Pahute Mesa to Oasis Valley did not have valid geochemical model solutions. A valid geochemical model solution is one that accounts for the changes in major-ion water chemistry between the initial and final waters along a flowpath by (1) reacting with minerals and gases identified in the aquifer, (2) from proportional mixing of chemically different waters (that can then also react with minerals and gases), (3) does not violate thermodynamic constraints (only minerals below saturation in the water can dissolve if present and only those that are above saturation in the water can precipitate from the water or by incongruent dissolution of another phase), and (4) the ${ }^{13} \mathrm{C}$ value of the water at the end of the flowpath can be produced from the initial water, or mixture of waters, by the geochemical reactions of the model solution. These flowpaths were shown to have valid geochemical models if groundwater from another source was allowed to mix with Pahute Mesa groundwater before reaching Oasis Valley, except for well ER-OV-6a. These are proposed flowpaths $1 \mathrm{~b}, 1 \mathrm{c}$, and 2 and they are discussed later in this chapter.

An example of a valid model solution for flowpath 1 using the chemical and isotopic composition for average Pahute Mesa groundwater and well ER-OV-1 groundwater, the closest Oasis Valley site to Pahute Mesa, is given by the following equation (Table 4-1; all mass transfers are in mmoles $/ \mathrm{kg}$ of water):

$$
\begin{gathered}
\text { ave. Pahute Mesa groundwater }+2.73 \text { glass }+0.87 \text { calcite }+1.11 \mathrm{NaCl}+0.33 \text { pyrite } \\
+0.78 \mathrm{Ca}-\mathrm{Mg} / \mathrm{Na} \text { exchange }-0.79 \mathrm{SiO}_{2}-0.10 \text { clay }-2.11 \text { zeolite }-0.30 \mathrm{~K} \text {-feldspar }= \\
\text { well ER-OV-1 groundwater }
\end{gathered}
$$

In this example, the dissolution of volcanic glass, calcite, $\mathrm{NaCl}$, and pyrite; the exchange of $\mathrm{Ca}$ and $\mathrm{Mg}$ in the water for $\mathrm{Na}$ on clays and zeolites in the aquifer, and the formation of $\mathrm{SiO}_{2}$, clay, zeolite, and K-feldspar produce the water chemistry observed at well ER-OV-1.

\section{$\underline{4.3 .4 \text { Flowpath } 1 \mathrm{~b}}$}

Modeling results for flowpath $1 \mathrm{~b}$, mixing of local Pahute Mesa recharge water with Pahute Mesa groundwater flowing to Oasis Valley, are presented in Table 4-1. The chemical and isotopic compositions of recharge on Pahute Mesa are not well defined, so water south of Pahute Mesa in Well UE-29a\#1 is used as representative recharge for Pahute Mesa. This site was chosen to represent local recharge for Pahute Mesa because it is in a similar hydrogeologic setting as Pahute Mesa and represents a well-integrated, modern recharge water in volcanic rocks in this area (see Chapters 2 and 3). Proposed flowpath $1 \mathrm{~b}$ has valid models for sites ER-OV-1, ER-OV-3c, ER-OV-4a, and Frans Spring in Oasis Valley (Table 4-1). Sites ER-OV-6a, Goss Spring, Baileys Hot Spring, ER-OV-2, and ER-OV-3a3 did not have valid geochemical model solutions (see section 4.2.2 for a description of what a valid geochemical model is). Thus, other 
flowpaths, water sources, or phase constraints are needed to explain these final water chemistries.

An example of a valid model solution for flowpath $1 \mathrm{~b}$ using the chemical and isotopic composition for average Pahute Mesa groundwater, well UE-29a\#1 groundwater, and well ER-OV-1 groundwater is given by the following equation (Table 4-1):

$$
\begin{gathered}
77 \% \text { ave. Pahute Mesa groundwater }+23 \% \text { well } \mathrm{UE}-29 \mathrm{a} \# 1 \text { groundwater }+0.28 \text { glass } \\
+1.10 \text { calcite }+1.11 \mathrm{NaCl}+0.34 \text { pyrite }+1.19 \mathrm{Ca}-\mathrm{Mg} / \mathrm{Na} \text { exchange }-0.56 \mathrm{SiO}_{2} \\
-0.09 \text { clay }-0.19 \mathrm{CO}_{2}=\text { well ER-OV-1 groundwater }
\end{gathered}
$$

In this example, the mixing of average Pahute Mesa groundwater with local Pahute Mesa recharge along with the dissolution of volcanic glass, calcite, $\mathrm{NaCl}$, and pyrite; the exchange of $\mathrm{Ca}$ and $\mathrm{Mg}$ in the water for $\mathrm{Na}$ on clays and zeolites; the formation of $\mathrm{SiO}_{2}$ and clay; and the exsolution of a small amount of $\mathrm{CO}_{2}$ gas produce the water chemistry observed at well ER-OV-1.

\section{$\underline{4.3 .5}$ Flowpath 1c}

Geochemical modeling results for proposed flowpath 1c, Pahute Mesa groundwater mixing with shallow groundwater in Oasis Valley that has undergone exchange with atmospheric gases, are given in Table 4-1. Geochemical and isotopic data for site 5 from White (1979) and White and Chuma (1987) are used to represent a shallow groundwater in Oasis Valley that has undergone exchange with atmospheric gases. This site was chosen because it is a large discharging spring in northern Oasis Valley that has undergone exchange with atmospheric gases as indicated by a DIC ${ }^{14} \mathrm{C}$ content of $100 \mathrm{pmc}$ (White and Chuma, 1987). Geochemical models were developed for all samples in the central part of Oasis Valley. Goss Spring and Well ER-OV-3a3 are included in these models even though they are hydraulically upgradient from samples in the central part of Oasis Valley, because they have undergone gas exchange with shallow soil-zone gases as indicated by noble gas and CFC concentrations (see Chapter 3). All sites for this potential flow have geochemically viable solutions (Table 4-1).

An example of a valid model solution for flowpath 1c using the chemical and isotopic compositions for average Pahute Mesa groundwater, site 5 groundwater in Oasis Valley, and Baileys Hot Spring is given by the following equation (Table 4-1):

$$
\begin{gathered}
64 \% \text { ave. Pahute Mesa groundwater }+36 \% \text { Site } 5 \text { groundwater }+0.21 \text { glass }+0.99 \text { calcite } \\
+0.38 \mathrm{NaCl}+0.35 \text { pyrite }+1.02 \mathrm{Ca}-\mathrm{Mg} / \mathrm{Na} \text { exchange }+0.21 \mathrm{CO}_{2}-0.44 \mathrm{SiO}_{2}-0.07 \text { clay } \\
=\text { Baileys Hot Spring groundwater }
\end{gathered}
$$

In this example, the mixing of average Pahute Mesa groundwater with shallow groundwater in Oasis Valley, along with the dissolution of volcanic glass, calcite, $\mathrm{NaCl}$, pyrite, and a small amount of $\mathrm{CO}_{2}$ gas; the exchange of $\mathrm{Ca}$ and $\mathrm{Mg}$ in the water for $\mathrm{Na}$ on clays and zeolites; and the formation of $\mathrm{SiO}_{2}$ and clay produces the water chemistry observed at Baileys Hot Spring.

\subsubsection{Flowpath 2}

Geochemical modeling results for flowpath 2, groundwater north of Oasis Valley mixing with Pahute Mesa groundwater and then flowing to Oasis Valley, are given in Table 4-1. Sites north of the Oasis Valley-Pahute Mesa area with both complete major-ion chemistry and isotopic data are limited to three springs in the Kawich Range and two wells in Cactus Flat (Appendix B). From these five sites, two sites were chosen as representative groundwaters from the north that could be flowing into the Oasis Valley-Pahute Mesa area. Rose Spring in the southern Kawich Range was chosen as the most representative spring from the Kawich Range. Rose Spring was 
chosen because it contained the heaviest (most positive) ${ }^{13} \mathrm{C}$ and least ${ }^{14} \mathrm{C}$ of the three springs in the Kawich Range indicating that the spring water was partially closed to atmospheric gases before discharging, as would be expected for recharge from the Kawich Range. Cedar Pass well in southeastern Cactus Flat, west of the Kawich Range, was chosen over the Roller Coaster Well (Sandia Well \#8). The Roller Coaster Well in southeastern Cactus Flat is likely a pocket of isolated groundwater of glacial age as indicated by the lightest deuterium and $\delta^{18} \mathrm{O}$ compositions of any groundwater in the study area (Appendix B and Chapter 3).

Groundwater discharging from Rose Spring has calcium greater than sodium plus potassium and bicarbonate is the major anion, whereas groundwater in the Cedar Pass well has sodium plus potassium greater than calcium and bicarbonate is the major anion (see Chapter 2). These are the two main water types north of the Oasis Valley-Pahute Mesa area. The geochemical reactions in the models needed to describe the changes in chemistry along this potential flowpath, in addition to mixing, are the same as listed previously in the discussion of the geochemical models (Table 4-1). The models differ by the amounts of phase mass transfers and some flowpaths can be modeled using several different phases.

Models that include Rose Spring as one mixing end member, and Pahute Mesa groundwater as the other end member, show that this flowpath is geochemically feasible for all but well ER-OV-6a and well UE-20bh\#1 to well ER-OV-1 (Table 4-1). Whereas, models that include the Cedar Pass well as a mixing end member in place of Rose Spring only have solutions for wells ER-OV-1, ER-OV-4a, and Frans Spring. Additionally, a model including average Pahute Mesa groundwater chemistry has a solution for well ER-OV-3c and a model including well UE-19h has a solution for Goss Spring.

An example of a valid model solution for flowpath 2 using the chemical and isotopic compositions for average Pahute Mesa groundwater, Rose Spring, and well ER-OV-1 is given by the following equation (Table 4-1):

$$
\begin{gathered}
85 \% \text { ave. Pahute Mesa groundwater }+15 \% \text { Rose Spring }+2.52 \text { feldspar }+0.33 \text { calcite } \\
+1.04 \mathrm{NaCl}+0.31 \text { pyrite }+0.62 \mathrm{Ca}-\mathrm{Mg} / \mathrm{Na} \text { exchange }-1.95 \mathrm{SiO}_{2}-0.62 \text { clay } \\
-1.01 \mathrm{~K}-\text { feldspar }=\text { well ER-OV- } 1 \text { groundwater }
\end{gathered}
$$

In this example, the mixing of average Pahute Mesa groundwater with Rose Spring along with the dissolution of a composite feldspar, calcite, $\mathrm{NaCl}$, and pyrite; the exchange of $\mathrm{Ca}$ and $\mathrm{Mg}$ in the water for $\mathrm{Na}$ on clays and zeolites; and the formation of $\mathrm{SiO}_{2}$, clay, and $\mathrm{K}$-feldspar produce the water chemistry observed at well ER-OV-1.

\subsubsection{Flowpath 3}

Geochemical modeling results for flowpath 3, groundwater north of Oasis Valley flowing to northwest Oasis Valley (well ER-OV-5 in the Springdale area), shows that this flowpath is geochemically feasible only if groundwater from a northerly source in addition to Tolicha Peak AFB Well \#1 is included in the model. A mixture of Rose Spring with Tolicha Peak AFB Well \#1 groundwater produced geochemically feasible models (Table 4-1). Using Cedar Pass well as a mixing end member with Tolicha Peak AFB Well \#1 did not produce an acceptable model (Table 4-1). A mixture of Rose Spring and Cedar Pass well groundwater also resulted in a viable geochemical model. 
An example of a valid model solution for flowpath 3 using the chemical and isotopic compositions of Tolicha Peak AFB Well \#1 groundwater, Rose Spring, and well ER-OV-5 groundwater is given by the following equation (Table 4-1):

$$
\begin{gathered}
38 \% \text { Tolicha Peak AFB Well \#1 groundwater }+62 \% \text { Rose Spring }+3.62 \text { glass } \\
+0.43 \mathrm{NaCl}+0.06 \text { pyrite }+0.43 \mathrm{Ca}-\mathrm{Mg} / \mathrm{Na} \text { exchange }+0.70 \text { analcime } \\
-0.52 \text { calcite }-3.31 \text { zeolite }-0.50 \text { clay }=\text { well ER-OV-5 groundwater }
\end{gathered}
$$

In this example, the mixing of Tolicha Peak AFB Well \#1 with Rose Spring along with the dissolution of volcanic glass, $\mathrm{NaCl}$, pyrite, and analcime; the exchange of $\mathrm{Ca}$ and $\mathrm{Mg}$ in the water for $\mathrm{Na}$ on clays and zeolites in the aquifer; and the formation of calcite, zeolite, and clay produce the water chemistry observed at well ER-OV-5. The 62\% Rose Spring mixing component exceeds $55 \%$, which is the $\delta^{18} \mathrm{O}+/-0.5 \%$ upper limit. However, $\delta \mathrm{D}$ data would allow for 0 to $100 \%$ mixing of either end-member component (Appendix B, Chapter 3), so this model was accepted as a reasonable solution.

\subsubsection{Flowpath 4}

Geochemical modeling results for flowpath 4, Pahute Mesa groundwater flowing south of Timber Mountain and then down the Beatty Wash area to Oasis Valley, show that this flowpath is geochemically feasible using reasonable geochemical reactions (Table 4-1). The chemistry for WW-8 in southeast Pahute Mesa was used as the initial water for Pahute Mesa groundwater. Samples in Beatty Wash (Coffers Windmill Well and well ER-OV-3c) and the three southernmost samples in Oasis Valley where Beatty Wash enters Oasis Valley (well ER-OV-4a, Frans Spring, and Baileys Hot Spring) are used as final waters for this proposed flowpath. This flowpath was also modeled assuming that local Pahute Mesa recharge water (as represented by well UE-29a\#1 groundwater) was mixing with Pahute Mesa groundwater. Model solutions were obtained for all waters except for Baileys Hot Spring.

An example of a valid model solution for flowpath 4 using the chemical and isotopic composition of WW-8 and well ER-OV-3c groundwaters is given by the following equation (Table 4-1):

$$
\begin{aligned}
\text { WW-8 groundwater }+ & 0.77 \text { feldspar }+0.98 \text { calcite }+0.28 \mathrm{NaCl}+0.14 \text { pyrite } \\
+0.88 \mathrm{Ca}-\mathrm{Mg} / \mathrm{Na} \text { exchange } & +0.11 \mathrm{CO}_{2}-0.18 \text { zeolite }-0.25 \text { analcime }-0.37 \mathrm{~K} \text {-feldspar } \\
& =\text { well ER-OV-3c groundwater }
\end{aligned}
$$

In this example, the dissolution of composite feldspar, calcite, $\mathrm{NaCl}$, pyrite, and a small amount of $\mathrm{CO}_{2}$ gas; the exchange of $\mathrm{Ca}$ and $\mathrm{Mg}$ in the water for $\mathrm{Na}$ on clays and zeolites; and the formation of zeolite, analcime, and K-feldspar produce the water chemistry observed at well ER-OV-3c. Several models exceeded the $0.20 \mathrm{mmoles} / \mathrm{kg} \mathrm{CO}_{2}$ gas dissolution/exsolution modeling limit for a groundwater system assumed to be closed to $\mathrm{CO}_{2}$ gas exchange. For these models to be valid, a source of $\mathrm{CO}_{2}$ gas would have to be entering the groundwater along this flowpath.

\section{$\underline{4.3 .9 \text { Flowpath } 5}$}

Geochemical modeling results for flowpath 5, Pahute Mesa groundwater flowing south down Fortymile Canyon, show that this flowpath is geochemically feasible using reasonable geochemical reactions if a local recharge water mixes with Pahute Mesa groundwater (Table 4-1). The chemistry for WW-8 in southeast Pahute Mesa was used for the Pahute Mesa groundwater. A groundwater sample from site J-13 in Fortymile Canyon was used as the final 
water for this proposed flowpath. The mixing model used well UE-29a\#1 groundwater in Fortymile Canyon as the local recharge water. Model solutions were not obtained without the addition of a local recharge water.

An example of a valid model solution for flowpath 5 using the chemical and isotopic compositions for WW-8, well UE-29a\#1, and well J-13 is given by the following equation (Table 4-1):

$$
\begin{gathered}
36 \% \mathrm{WW}-8 \text { groundwater }+64 \% \text { well } \mathrm{UE}-29 \mathrm{a} \# 1 \text { groundwater }+1.77 \text { glass }+0.06 \text { calcite } \\
+0.01 \text { pyrite }+0.44 \mathrm{CO}_{2}-0.03 \mathrm{NaCl}-1.59 \text { zeolite }-0.02 \text { analcime }-0.18 \mathrm{~K} \text {-feldspar } \\
=\text { well } \mathrm{J}-13 \text { groundwater }
\end{gathered}
$$

In this example, the mixing of WW-8 groundwater with well UE-29a\#1 groundwater along with the dissolution of volcanic glass, calcite, pyrite, and some $\mathrm{CO}_{2}$ and the formation of zeolite, analcime, and K-feldspar produce the water chemistry observed at well J-13. The formation of 0.03 mmoles of $\mathrm{NaCl}$ would not happen, but this extremely small amount is within both analytical and model error. The dissolution of 0.44 mmoles of $\mathrm{CO}_{2}$ gas exceeds the model limit of $0.20 \mathrm{mmoles} / \mathrm{kg}$, requiring a source of $\mathrm{CO}_{2}$ gas to be entering the groundwater along the flowpath for this model to be valid.

\subsubsection{Flowpath Summary}

In summary, most proposed flowpaths are geochemically feasible assuming plausible geochemical reactions. For groundwater flow from Pahute Mesa to Oasis Valley (flowpath 1), model solutions were obtained for most Oasis Valley groundwaters only if a source of water in addition to Pahute Mesa groundwater was included in the model (flowpaths 1b, 1c, and 2). Neither flowpaths 1 or 2 had valid geochemical models for groundwater sampled from well ER-OV-6a, within the proposed model limits (Table 4-1). Flowpath 1b, mixing of local Pahute Mesa recharge water with Pahute Mesa groundwater to Oasis Valley, had model solutions for sites ER-OV-1, ER-OV-3c, ER-OV-4a, and Frans Spring. About half of the sites, ER-OV-6a, Goss Spring, Baileys Hot Spring, ER-OV-2, and ER-OV-3a3, did not have model solutions. Model solutions were obtained for all groundwaters along flowpath 1c, mixing of Pahute Mesa groundwater with shallow water in Oasis Valley that had undergone exchange with atmospheric gases to central Oasis Valley. For flowpath 3, groundwater north of Oasis Valley flowing to northwest Oasis Valley, model solutions needed a northerly groundwater mixing with Tolicha Peak AFB Well \#1 groundwater. No model solutions were obtained using Tolicha Peak AFB Well \#1 groundwater as the sole source of northerly water for northwest Oasis Valley groundwater (well ER-OV-5). Flowpath 4, Pahute Mesa groundwater flowing south of Timber Mountain to the Beatty Wash area of Oasis Valley, had viable geochemical models for all but Baileys Hot Spring, although several models exceeded the proposed $\mathrm{CO}_{2}$ gas mass-transfer limit of $0.20 \mathrm{mmoles} / \mathrm{kg}$ (assumes a system closed to gas exchange). Flowpath 5, Pahute Mesa groundwater flowing south down Fortymile Canyon, has viable geochemical models if a local recharge water is mixed with Pahute Mesa groundwater and a small amount of $\mathrm{CO}_{2}$ gas is being added to the groundwater along the flowpath.

\subsubsection{Limitations of the Geochemical Models}

Geochemical models presented in this report are limited by available data. These limitations include (1) solid-phase information was only available for core samples from Pahute Mesa, (2) sites with complete water chemistry and isotopic data for groundwater flowing into the Pahute Mesa area from the north are only available for four sites (Appendix B), (3) ${ }^{13} \mathrm{C}$ data for 
fracture filling calcite in the saturated zone are limited to a small number of cores from Pahute Mesa (Rose et al., 1998b; and Tables 1-3 and 1-4), and (4) our lack of understanding of carbon isotope diffusion processes. Solid-phase chemical and isotopic data used for the geochemical modeling are limited to samples collected from Pahute Mesa. Other as yet unidentified phases, or changes in chemical composition of phases along flowpaths, between Pahute Mesa and Oasis Valley and in the Oasis Valley discharge area are unknown. New, or chemically different, phases along flowpaths to Oasis Valley and in the Oasis Valley discharge area could result in different geochemical models than the ones produced with the current knowledge of solid-phase chemistry.

Several of the geochemical models require mixing of groundwater from a source north of Pahute Mesa with Pahute Mesa groundwater to obtain the chemical and isotopic compositions of groundwater in Oasis Valley. The chemical and isotopic composition of groundwater north of Pahute Mesa that mixes with Pahute Mesa groundwater as it flows to Oasis Valley is difficult to define. Only four samples in the Cactus Flat-Kawich Range-Kawich Valley area have complete chemical and isotopic analyses. These limited data may not represent the chemistry of water flowing into the Pahute Mesa-Oasis Valley area from the north.

All of the geochemical models require an input of heavy $\delta^{13} \mathrm{C}$ to obtain measured $\delta^{13} \mathrm{C}$ values in groundwater at the end of flowpaths in Oasis Valley. Secondary calcite coatings on fracture surfaces are the source of this heavy $\delta^{13} \mathrm{C}$ in the models. The average $\delta^{13} \mathrm{C}$ value of secondary calcite in the saturated zone is $+1.6 \%$ (Tables 1-3 and 1-4). Carbonate rocks in southern Nevada that underlie volcanic rocks in the Pahute Mesa-Oasis Valley area have a similar $\delta^{13} \mathrm{C}$ value $(+1.2 \%$; Thomas et al., 1996), so if some of the calcite that is dissolving is from carbonate rock, this would produce a similar model as the fracture-lining calcite models. The heavy $\delta^{13} \mathrm{C}$ values of groundwater in Oasis Valley could also result from another, as yet unidentified, carbon-containing phase; fracture-lining calcites from areas that have not been investigated; or carbon isotope diffusion.

\subsection{Groundwater Travel-time Estimates}

Groundwater travel times (ages) were calculated using the geochemical models developed for examining processes responsible for changes in groundwater chemistry along proposed flowpaths. The changes in groundwater chemistry include changes in DIC, which in turn can be used to account for changes in ${ }^{14} \mathrm{C}$ compositions resulting from geochemical reactions (not radioactive decay) by using ${ }^{13} \mathrm{C}$. Then the difference between corrected ${ }^{14} \mathrm{C}$ values, corrected for geochemical reactions, and measured ${ }^{14} \mathrm{C}$ values can be used to calculate groundwater ages (the difference in values is assumed to be due to radioactive decay) and hence travel times. Groundwater ages were also calculated for carbon isotopes of DOC.

\subsubsection{Dissolved Inorganic Carbon}

Groundwater travel times can be calculated by accounting for changes in the chemical and carbon isotopic compositions between initial and final waters along a flowpath. The model calculations account for the mass transfers of inorganic carbon between the groundwater and solid and gas phases by using the stable carbon isotope,${ }^{13} \mathrm{C}$. The calculations also account for ${ }^{13} \mathrm{C}$ and ${ }^{14} \mathrm{C}$ fractionations that take place during chemical reactions. To calculate a travel time, a set of plausible geochemical reactions that describe the changes in water chemistry between initial and final waters along a flowpath (in addition to changes due to mixing) has to be developed, and the model needs to include carbon isotope values for those phases containing 
carbon. To obtain a valid model solution, the calculated ${ }^{13} \mathrm{C}$ composition has to match the measured value in the final water and account for all the changes in chemistry between the initial and final waters. There is no unique solution for the changes in chemical and isotopic compositions of groundwater along a flowpath. Thus, model solutions using plausible phases (solids and gases) of known chemical and isotopic compositions, that are observed to be reacting with groundwater within the aquifer, are valid for reasonable amounts of mass transfers between phases provided the isotopic constraints are met as well. The model-calculated groundwater ages represent travel times of groundwater in the Oasis Valley flow system, rather than true groundwater ages, because Pahute Mesa groundwaters have low ${ }^{14} \mathrm{C}$ activities. These low ${ }^{14} \mathrm{C}$ activities indicate that the Pahute Mesa groundwaters are likely to be several thousand years old.

Groundwater age calculations should not be interpreted as exact ages, but rather as ages determined within a range of about $\pm 2,000$ years (less than one-half of one half-life of ${ }^{14} \mathrm{C}$, which is 2,865 years). This range in uncertainty for calculated ages results from the analytical uncertainty of ${ }^{14} \mathrm{C}$ measurements, the unknown value of recharge ${ }^{14} \mathrm{C}$ composition (generally 55 to $110 \mathrm{pmc}$ depending on if groundwater in the recharge area is closed $(55 \mathrm{pmc})$, open (110 pmc), or partially open (55 to $110 \mathrm{pmc}$ ) to exchange with atmospheric $\mathrm{CO}_{2}$ gas), and the very low ${ }^{14} \mathrm{C}$ values of some of the samples. As ${ }^{14} \mathrm{C}$ concentration decreases, smaller variations in ${ }^{14} \mathrm{C}$ ${ }^{14} \mathrm{C}$ content can result in bigger age changes. For example, if a ${ }^{14} \mathrm{C}$ content of groundwater is 5.0 pmc, like in well ER-OV-1, a model-calculated value of $7.0 \mathrm{pmc}$, which is only a 2 percent difference in ${ }^{14} \mathrm{C}$, represents a change in age of 2,800 years.

\subsubsection{Flowpath 1}

For flowpath 1, limited model solutions were obtained for wells ER-OV-1, ER-OV-3a3, ER-OV-3c, ER-OV-4a, Goss Spring, and Frans Springs (Table 4-1). Groundwater ages calculated for these model solutions range from modern to 4,700 years. A model that uses the average chemistry of the five Pahute Mesa groundwaters as the initial water chemistry results in calculated ages ranging from modern to 1,200 years. The limited number of model solutions indicates that this flowpath is probably not representative of most groundwater flow into Oasis Valley. Instead, groundwater flowing from Pahute Mesa to Oasis Valley is likely a mixture of younger water containing more ${ }^{14} \mathrm{C}$ than Pahute Mesa groundwaters.

\subsubsection{Flowpath $1 b$}

Adding a local Pahute Mesa recharge component to flowpath 1 did not result in more Oasis Valley samples having successful model simulations. However, groundwater-age calculations for the same sites as flowpath 1 result in older groundwater ages than flowpath 1, ranging from 1,900 to 6,200 years, except for one solution for well ER-OV-4a and one solution for Frans Spring. Similar to flowpath 1 models, using the average chemistry of Pahute Mesa groundwaters for flowpath $1 \mathrm{~b}$ generally resulted in younger calculated ages. The older calculated ages for this flowpath are expected because of the addition of up to 26 percent local recharge water (containing $76 \mathrm{pmc}$ ) to the low ${ }^{14} \mathrm{C}$ Pahute Mesa groundwaters (Table 4-1).

\subsubsection{Flowpath 1c}

For flowpath 1c, calculated groundwater age ranges from 3,500 to 4,900 years for the models using average Pahute Mesa groundwater chemistry, except for sites ER-OV-4a and Frans Spring. Groundwater from well ER-OV-4a and Frans Spring contained only 8.0 and 12.9 pmc, respectively, as compared to 16 to $24 \mathrm{pmc}$ for the other sites. These lower ${ }^{14} \mathrm{C}$ values indicate 
little mixing of shallow groundwater, or atmospheric gas exchange, with ER-OV-4a and Frans Spring groundwaters. Frans Spring also has a $\delta^{13} \mathrm{C}$ value of $-1.9 \%$ as compared to -3.5 to $-2.2 \% \delta^{13} \mathrm{C}$ for the other groundwater samples from the central Oasis Valley area, another indication of little mixing with shallow, lighter ${ }^{13} \mathrm{C}$ groundwater or atmospheric gas exchange. Flowpath 1c was not modeled for Oasis Valley wells outside of the central part of Oasis Valley, because they are outside the area of potential shallow groundwater mixing or the area affected by atmospheric gas exchange with the groundwater.

\subsubsection{Flowpath 2}

For flowpath 2, calculated groundwater ages range from modern to 5,900 years for the models using Rose Spring as the northern end member that mixes with average Pahute Mesa groundwater. Modeling results show two groups of calculated ages, one for samples outside of the central part of Oasis Valley, which contain less than $10 \mathrm{pmc}$, and those in the central part of Oasis Valley, which have greater than 10 pmc except for well ER-OV-4a. Wells ER-OV-1 and ER-OV-3c, outside of central Oasis Valley, have calculated ages ranging from 3,600 to 4,900 years (Table 4-1). Calculated groundwater ages for sites in central Oasis Valley range from modern to 180 years, with the exception of well ER-OV-4a, which contains only 8.0 pmc, which is similar to ${ }^{14} \mathrm{C}$ concentrations of the noncentral Oasis Valley groundwaters.

For flowpath 2, calculated groundwater age ranges from modern to 430 years for the models using Cedar Pass well as the northern end member that mixes with average Pahute Mesa groundwater. Modeling results show that samples from wells outside of the central part of Oasis Valley have groundwater ages ranging from modern to 430 years. Groundwaters in the central part of Oasis Valley have calculated ages that are modern for two sites and the other sites did not have model solutions (Table 4-1).

\subsubsection{Flowpath 3}

For flowpath 3, calculated groundwater age ranges from 1,000 to 1,800 years (Table 4-1). This range in groundwater ages is for models with Rose Spring mixing with Tolicha Peak AFB Well \#1 groundwater and Rose Spring mixing with Cedar Pass well groundwater flowing to well ER-OV-5.

\subsubsection{Flowpath 4}

For flowpath 4, calculated groundwater age ranges from modern to 5,200 years for Pahute Mesa groundwater, as measured at WW-8 (Table 4-1). Calculated groundwater age ranges from modern to 7,200 years when a local Pahute Mesa recharge source is included as an additional source of water in the model. Excluding Frans Spring, because it contains groundwater that is more than $2.0 \%$ heavier in $\delta^{13} \mathrm{C}$ than the other final groundwaters for this flowpath and models for this site require a large $(0.83$ to $0.99 \mathrm{mmoles} / \mathrm{kg}) \mathrm{CO}_{2}$ gas input, the calculated ages range from 2,600 to 7,200 years. Further restricting the calculated model ages to the proposed $\mathrm{CO}_{2}$ gas mass-transfer limit of $0.20 \mathrm{mmoles} / \mathrm{kg}$ of water, results in modeled ages ranging from 2,600 to 3,300 years.

\subsubsection{Flowpath 5}

For flowpath 5, calculated groundwater age ranges from 2,900 to 4,200 years. A model solution for this flowpath requires the input of a local Fortymile Canyon recharge component to mix with Pahute Mesa groundwater. Both model solutions require input of $\mathrm{CO}_{2}$ gas that exceeds 
the proposed closed system model limit. Thus, for these models to be reasonable, about 0.40 mmoles of $\mathrm{CO}_{2}$ gas per $\mathrm{kg}$ of water needs to be added to the groundwater along the flowpath. This condition is probably a reasonable condition in a hydrologic environment like Fortymile Canyon, where coarse-grained sediments along the wash could allow gas exchange across a relatively shallow unsaturated zone, as compared to the deep unsaturated zone beneath Pahute Mesa.

\subsubsection{Dissolved Organic Carbon}

Carbon isotopes of DOC (Appendix B) also can be used to estimate groundwater ages (Thomas, 1996). Three DOC ages were calculated for each Oasis Valley site using different recharge water ${ }^{14} \mathrm{C}$ values (Table 4-3). One age was calculated using the average ${ }^{14} \mathrm{C}$ DOC value measured for wells UE-29a\#1 and UE-29a\#2 along Fortymile Wash (66 pmc), a second age was calculated using the average ${ }^{14} \mathrm{C}$ value of 11 duplicate analyses for a recharge site in the nearby Spring Mountains ( $91 \pm 1.5 \mathrm{pmc}$, Cold Creek Spring), and a third age was calculated using 100 pmc (assumes no ${ }^{14} \mathrm{C}$ of less than 100 pmc was added from organic material in the unsaturated zone during recharge). The following discussion of DOC calculated ages uses the Age 2 calculations from Table 4-3, because these ages are calculated using an initial DOC ${ }^{14} \mathrm{C}$ value that is the average of 11 duplicate analyses for a single recharge water. Carbon-14 DOC-calculated age ranges from 1,500 to 6,800 years for Oasis Valley groundwaters, excluding the Springdale Upper Well, because it contains modern DOC. The Springdale Upper Well sample contained $95 \mathrm{pmc}$ DOC, indicating local recent recharge of a shallow water or contamination of the sample with DOC of modern age. Tolicha Peak AFB Well \#1, which is several miles north of Oasis Valley and does not contain Pahute Mesa groundwater, has a DOC-calculated age of 11,000 years. The DOC for this sample contains only $23 \mathrm{pmc}$ and is likely the oldest water sampled for this study. Two samples, well ER-OV-3a3 and Baileys Hot Spring, were contaminated with ${ }^{14} \mathrm{C}$ above natural atmospheric levels, so an age could not be calculated for these samples. A historic sample (collected September 27, 1996) of Baileys Hot Spring had a DOC ${ }^{14} \mathrm{C}$ value of $42 \mathrm{pmc}$, which results in a calculated age of 6,400 years. This age is at the upper end of DOC ages of groundwater in Oasis Valley and is similar to the DOC age of nearby ER-OV-4a well water (6,800 years).

One sample for deep groundwater beneath Pahute Mesa, U-20 WW, has a DOC-calculated age of 2,400 years (Table 4-3). The sites in Oasis Valley geographically closest to Pahute Mesa, wells ER-OV-1 and ER-OV-6a, have DOC-calculated ages of 1,700 and 2,100 years, respectively. The similar age of the Pahute Mesa groundwater and the two Oasis Valley groundwaters indicates a rapid groundwater travel time between western Pahute Mesa and Oasis Valley. However, the Oasis Valley groundwaters likely are a mixture of groundwater beneath Pahute Mesa with a groundwater from north of Pahute Mesa and local recharge, so a direct comparison of DOC ages between Pahute Mesa and Oasis Valley groundwaters cannot be used to estimate travel times. A site in the northwest part of Oasis Valley, well ER-OV-5, has an estimated DOC groundwater age of 1,500 years. Two sites in Beatty Wash, Coffers Windmill Well and well ER-OV-3c, have DOC-calculated groundwater ages of 4,200 and 3,000 years, respectively. Sites in the central part of Oasis Valley--in the area where Beatty Wash enters Oasis Valley--Baileys Hot Spring and well ER-OV-4a, have DOC-calculated groundwater ages of 6,400 and 6,800 years, respectively. 
Table 4-3. DOC ${ }^{14} \mathrm{C}$-calculated groundwater ages. Age 1 is for an initial ${ }^{14} \mathrm{C}$ DOC value of $66 \mathrm{pmc}$ (average of UE-29a\#1 and \#2), age 2 is for an initial ${ }^{14} \mathrm{C}$ DOC value of $91 \mathrm{pmc}$ (average of 11 samples from Cold Creek Spring in the Spring Mountains), age 3 is for an initial ${ }^{14} \mathrm{C}$ DOC value of 100 pmc (assumes no dead carbon added from the unsaturated zone). Symbols: NA, not analyzed; IC, insufficient organic carbon in sample for analysis.

\begin{tabular}{|c|c|c|c|c|c|c|}
\hline Site Name & $\begin{array}{c}\mathrm{DOC} \\
(\mathrm{mg} / \mathrm{L})\end{array}$ & $\begin{array}{l}\text { DOC } \\
{ }^{13} \mathrm{C} \\
(\%)\end{array}$ & $\begin{array}{c}{ }^{\mathrm{DOC}} \\
{ }^{14} \mathrm{C} \\
\text { (percent modern) }\end{array}$ & $\begin{array}{c}\text { Age } 1 \\
\text { (yrs) }\end{array}$ & $\begin{array}{c}\text { Age } 2 \\
\text { (yrs) }\end{array}$ & $\begin{array}{c}\text { Age } 3 \\
\text { (yrs) }\end{array}$ \\
\hline ER-OV-01 Well & 0.2 & -22.4 & $74+/-0.5$ & modern & 1,700 & 2,500 \\
\hline ER-OV-02 Well & 0.1 & $-30.9 /-32.5$ & $41+/-2.9$ & 3,900 & 6,600 & 7,400 \\
\hline ER-OV-03a Well & NA & NA & NA & -- & -- & -- \\
\hline ER-OV-03a2 Well & NA & NA & NA & -- & -- & -- \\
\hline ER-OV-03a3 Well & 0.2 & -25.4 & $121^{\mathrm{a}}+/-1.4$ & -- & -- & -- \\
\hline ER-OV-03c Well & 0.3 & -26.0 & $63+/-1.0$ & 380 & 3,000 & 3,800 \\
\hline ER-OV-04a Well & 0.1 & -27.7 & $40+/-2.8$ & 4,100 & 6,800 & 7,600 \\
\hline ER-OV-05 Well & 0.1 & -28.6 & $76+/-0.9$ & modern & 1,500 & 2,300 \\
\hline ER-OV-06a Well & 0.1 & -22.2 & $71+/-1.6$ & modern & 2,100 & 2,800 \\
\hline Coffers Windmill Well & 0.1 & -27.6 & $55+/-1.4$ & 1,500 & 4,200 & 4,900 \\
\hline U-20 WW & 0.2 & -26.1 & $68+/-4.3$ & modern & 2,400 & 3,200 \\
\hline WW-8 (USGS HTH \#8) & 0.3 & -25.5 & IC & -- & -- & -- \\
\hline UE-29a \#1 HTH Well & 0.2 & -32.0 & $67^{b}+/-1.2$ & -- & -- & -- \\
\hline UE-29a \#2 HTH Well & 0.2 & -28.8 & $64^{b}+/-0.6$ & -- & -- & -- \\
\hline Tolicha Peak AFB Well \#1 & 0.1 & -32.0 & $23+/-0.9$ & 8,700 & 11,000 & 12,000 \\
\hline Springdale Upper Well & 0.1 & -27.0 & $95+/-1.5$ & modern & modern & 420 \\
\hline Rita Mullen Spring & NA & NA & NA & -- & -- & -- \\
\hline Baileys Hot Spring Bath House 1 & 0.2 & -25.9 & $172^{\mathrm{a}}+/-1.6$ & -- & -- & -- \\
\hline Baileys Hot Spring (9-27-1996) & 0.2 & -27.8 & 42 & 3,900 & 6,400 & 7,200 \\
\hline Frans (Angels) Spring & NA & NA & NA & -- & -- & -- \\
\hline Goss Springs North & 0.1 & -26.0 & IC & -- & -- & -- \\
\hline
\end{tabular}

Carbon-13 values of DOC also provide important information about the source of the DOC in the groundwater. DOC in recharge groundwaters of southern Nevada should have DOC values ranging from about -30 to $-25 \%$, typical of $\mathrm{C}_{3}$-type vegetation and observed for other southern Nevada groundwaters (Thomas, 1996). Values more negative than $-30 \%$, as observed for well ER-OV-2, Tolicha Peak AFB Well \#1, and UE-29a\#1 HTH well, indicate that the DOC may have been fractionated by biological processes or leached from old organic material in the aquifer. Thus, the DOC ages for water from wells ER-OV-2 (6,600 years) and Tolicha Peak AFB \#1 (11,000 years) may be younger than calculated. Also of importance are the heavy (less negative) ${ }^{13} \mathrm{C}$ values for samples for ER-OV-1 and ER-OV-6a. These heavier values may indicate a lower altitude recharge component in these groundwaters from $\mathrm{C}_{4}$-type vegetation, which produces less negative ${ }^{13} \mathrm{C}$ values than $\mathrm{C}_{3}$-type vegetation. $\mathrm{DOC}{ }^{14} \mathrm{C}$ calculated ages are usually considered to represent maximum ages because of the possibility of the addition of dead ${ }^{14} \mathrm{C}$ from aquifer material. However, groundwater in the recently drilled ER-OV wells may contain organic material from fluids used during well drilling. This material may be from polymers that have no ${ }^{14} \mathrm{C}$ or materials that contain modern ${ }^{14} \mathrm{C}$. The low DOC concentration of 
the groundwater samples, 0.1 to $0.3 \mathrm{mg} / \mathrm{L}$, indicates that little DOC has been added to the groundwater, but because of the very low DOC concentrations, DOC contamination from drilling fluids is a concern. Groundwater ages calculated from $\mathrm{DOC}{ }^{14} \mathrm{C}$ indicate that travel times to Oasis Valley are in the range of 1,500 to 6,800 years, with groundwater from sites in the same areas of Oasis Valley having a narrower range in age. If the one sample from U-20 WW on western Pahute Mesa is representative of DOC carbon isotopes for groundwater beneath Pahute Mesa, then groundwater travel times between Pahute Mesa and Oasis Valley are less than 1,500 to 6,800 years. However, because most flowpaths involve mixing groundwater from north of Pahute Mesa and/or local recharge with groundwater beneath Pahute Mesa to produce the groundwater chemistry observed in Oasis Valley (Chapter 3 and this chapter), the amount of reduction in these travel times is unknown.

The use of DOC ages for travel-time estimates for specific flowpaths is limited because DOC carbon isotopes for the potentially different recharge source areas are limited (Table 4-3). However, DOC carbon isotopes in groundwater in recharge areas are likely similar for mountainous areas throughout southern Nevada because of similar vegetation. Recharge from surface water along washes may produce different DOC carbon isotope values than the more typical mountain block recharge. Thus, DOC-calculated ages for groundwater discharging in Oasis Valley are reasonable estimates, but likely will change if a significant source of this groundwater is surface water recharge in low-altitude washes as compared to high-altitude mountain-block recharge. The determination of DOC travel times for specific flowpaths to Oasis Valley depends on the sources of groundwater supplying wells and springs in the valley. In summary, calculated DOC ages for groundwaters in Oasis Valley that range from 1,500 to 6,800 years provide a good estimate of travel times for groundwater to reach Oasis Valley. The majority of this water originates as deep groundwater beneath the Pahute Mesa area, but some of the groundwater likely originates from north of Oasis Valley and/or as local recharge either on Pahute Mesa or within major washes.

\subsection{Summary}

As shown by hydrologic, geologic, geochemical, and isotopic data, groundwater beneath Pahute Mesa is a major source of groundwater that discharges in Oasis Valley. This conclusion was reached in the first hydrogeologic study of the Pahute Mesa area by Blankennagel and Weir (1973). Tritium data indicate that groundwater discharging in Oasis Valley is greater than 50 years old. The time it takes groundwater to flow from Pahute Mesa to Oasis Valley can be estimated by using geochemical models that incorporate isotopes of DIC and by using DOC isotopic data. Five potential flowpaths for groundwater discharging in Oasis Valley were investigated using geochemical models. The flowpaths include (1) Pahute Mesa groundwater to Oasis Valley; (2) groundwater north of Oasis Valley mixing with Pahute Mesa groundwater to Oasis Valley (3) groundwater north of Oasis Valley to northwest Oasis Valley (Springdale area); (4) Pahute Mesa groundwater to south of Timber Mountain through the Beatty Wash area to Oasis Valley; and (5) Pahute Mesa groundwater down Fortymile Canyon. Two variations of flowpath (1) were also investigated: Flowpath 1b, mixing local recharge on Pahute Mesa with Pahute Mesa groundwater to Oasis Valley and flowpath 1c, Pahute Mesa groundwater mixing with shallow groundwater in Oasis Valley that has undergone exchange with atmospheric gases.

Most flowpaths and mixing of groundwaters proposed on the basis of hydrologic, geologic, and water isotopic and chemical data have geochemical model solutions with plausible geochemical reactions. For groundwater flow from Pahute Mesa to Oasis Valley (flowpaths 1 
and 2), model solutions were obtained for most Oasis Valley groundwaters only if a source of water in addition to Pahute Mesa groundwater was included in the model (flowpaths 1b, 1c, and 2). Flowpath 3 only had model solutions for mixing a more northerly groundwater with Tolicha Peak AFB Well \#1 groundwater to obtain the groundwater chemistry in northwestern Oasis Valley. No model solutions were obtained using Tolicha Peak AFB Well \#1 as the sole source of northerly groundwater for this flowpath. Flowpath 4 had viable geochemical models for all but Baileys Hot Spring, although several models exceeded the proposed mass-transfer limit of 0.20 mmoles of $\mathrm{CO}_{2}$ gas per kg of water. Helium data (Chapter 3) indicates that about 20 percent of the helium in Baileys Hot Spring is mantle derived helium and most other Oasis Valley groundwaters also contained some mantle gas. This mantle gas influx would also include $\mathrm{CO}_{2}$ gas, so a mass-transfer exceeding 0.20 mmoles per $\mathrm{kg}$ of water is a viable model if the source is mantle- $\mathrm{CO}_{2}$ gas. Flowpath 5 had viable geochemical models if a local Fortymile Canyon recharge water was mixed with Pahute Mesa groundwater and a small amount of $\mathrm{CO}_{2}$ gas $(0.39$ to $0.44 \mathrm{mmoles} / \mathrm{kg})$ was added to the groundwater along the flowpath. For flowpath 5 , the addition of $\mathrm{CO}_{2}$ gas would likely be from groundwater recharge along Fortymile Wash rather than a mantle gas source.

Based on DIC ${ }^{14} \mathrm{C}$, two populations of groundwater exist in Oasis Valley for groundwater age dating. The populations include groundwater in the central part of Oasis Valley, which contain greater than 10 pmc (except for well ER-OV-4a), and groundwater east and upgradient of this area, which contains less than 10 pmc. Groundwater in wells and springs in the central part of Oasis Valley appear to have a local groundwater mixing component, or at least atmospheric gas exchange, as previously documented for shallow groundwaters flowing from north to south in Oasis Valley (White and Chuma, 1987). This mixing of shallow groundwater that has undergone exchange with atmospheric gases with deeper groundwater (or gas exchange through the unsaturated zone with the deeper groundwater) produces an increased ${ }^{14} \mathrm{C}$ in these groundwaters that exceeds 10 pmc. Wells outside of the central part of Oasis Valley appear to represent groundwater flow into this area without any local mixing of groundwater (or gas exchange through the unsaturated zone). Geochemical models that account for mixing of a shallow Oasis Valley groundwater (flowpath 1c) with Pahute Mesa groundwater result in calculated groundwater ages that range from 3,500 to 4,900 years (Table 4-1; excluding well ER-OV-4a and Frans Spring, which contains ${ }^{13} \mathrm{C}$ that is $2 \%$ heavier than all other central Oasis Valley groundwaters, indicating no shallow groundwater mixing or gas exchange). All other flowpath models for these sites result in modern calculated groundwater ages. For samples with less than 10 pmc to the east of central Oasis Valley (wells ER-OV-1 and ER-OV-3c), mixing a local Pahute Mesa recharge water with Pahute Mesa groundwater (flowpath 1b) or mixing a northerly recharge water (represented by Rose Spring in the Kawich Range) with Pahute Mesa groundwater (flowpath 2) results in model-calculated ages ranging from 1,900 to 6,200 years. No model solutions were obtained for well ER-OV-6a, within the limits set for valid model solutions.

Model-calculated groundwater ages for northwest Oasis Valley groundwater range from 1,000 to 1,800 years (flowpath 3; Table 4-1). Model-calculated groundwater ages for flow from southeast Pahute Mesa to the Beatty Wash area of Oasis Valley range from 2,600 to 6,100 years (flowpath 4; Table 4-1). Model-calculated groundwater ages for flow from southeast Pahute Mesa to Well J-13 in Fortymile Canyon range from 2,900 to 4,200 years (flowpath 5; Table 4-1). 
The ${ }^{14} \mathrm{C}$ DOC-calculated ages compare reasonably well with DIC-modeled ${ }^{14} \mathrm{C}$ ages (Table 4-4). DOC ${ }^{14} \mathrm{C}$ ages for the central Oasis Valley sites range from 6,400 years, for Baileys Hot Spring, to 6,600 years for well ER-OV-3a3, as compared to 3,900 to 4,900 years for modelcalculated groundwater ages for these sites. DOC ${ }^{14} \mathrm{C}$ ages for samples east of central Oasis Valley range from 1,700 years, for well ER-OV-1, to 3,000 years, for well ER-OV-3c, as compared to DIC-model-calculated ages of 3,000 to 5,200 years. The DOC groundwater age for northwest Oasis Valley groundwater is 1,500 years as compared to DIC calculated ages of 1,000 to 1,800 years. Coffers Windmill Well has a DOC-estimated groundwater age of 4,200 years as compared to modeled DIC ages of 5,200 to 6,100 years.

Model calculated groundwater ages from DIC data indicate that travel times to Oasis Valley from Pahute Mesa, for a mixture of waters, range from 1,900 to 6,200 years. DOC-estimated groundwater ages in Oasis Valley range from 1,700 to 6,800 years. Travel times for southeast Pahute Mesa to the Beatty Wash area of Oasis Valley range from 2,600 to 4,200 years, for model-calculated travel times and DOC ages. Travel time for southeast Pahute Mesa to Well J-13 in Fortymile Canyon ranges from 2,900 to 4,200 years. Travel time for groundwater originating north of Oasis Valley to northwest Oasis Valley is about 1,500 years. DIC-calculated travel times and DOC-estimated ages indicate that groundwater flow from Pahute Mesa to Oasis Valley is in the range of about 2,000 to 6,000 years, for a mixture of waters.

Table 4-4. A comparison of DIC and DOC groundwater ages. DIC age is for flowpaths 1b, 1c, 2, 3, and 4 (the flowpaths for a specific site can be obtained from Table 4-1).

\begin{tabular}{ccc}
\hline Site Name & $\begin{array}{c}\text { DIC Age } \\
\text { (yrs) }\end{array}$ & $\begin{array}{c}\text { DOC Age } \\
\text { (yrs) }\end{array}$ \\
\hline ER-OV-01 Well & $3,000-5,200$ & 1,700 \\
ER-OV-02 Well & 3,500 & 6,600 \\
ER-OV-03c Well & $4,200-4,900$ & 3,000 \\
ER-OV-04a Well & $2,600-6,200$ & 6,800 \\
ER-OV-05 Well & $1,000-1,800$ & 1,500 \\
ER-OV-06a Well & none & 2,100 \\
Coffers Windmill Well & $5,200-6,100$ & 4,200 \\
Bailey Hot Springs (9-27-1996) & 4,100 & 6,400 \\
\hline
\end{tabular}




\section{CONCLUSIONS}

This report summarizes the findings of a geochemical investigation of the Pahute MesaOasis Valley groundwater flow system in southwestern Nevada, funded by the Underground Test Area (UGTA) project of the U.S. Department of Energy, National Nuclear Security Administration Nevada Operations Office. This work is intended to provide geochemical data and interpretations in support of flow and contaminant transport modeling for the Western and Central Pahute Mesa Corrective Action Units (PM-CAUs). The PM-CAUs are two of six underground test areas on the Nevada Test Site (NTS) under investigation by the UGTA project, as required by the Federal Facility Agreement and Consent Order (FFACO, 1996).

The data described in this report were assembled by a consortium of geochemists from the Desert Research Institute, Harry Reid Center for Environmental Studies at the University of Nevada, Las Vegas, Geotrans Inc., Lawrence Livermore National Laboratory, and the U.S. Geological Survey. The Pahute Mesa-Oasis Valley groundwater flow system is of particular concern because of the relatively short distance $(\sim 30 \mathrm{~km})$ between the Pahute Mesa underground test areas and the groundwater discharge area in Oasis Valley. Groundwater flow and transport modeling simulations show potential rapid tritium $\left({ }^{3} \mathrm{H}\right)$ transport in the fractured volcanic rock aquifers along flowpaths in this region. This geochemical investigation fulfills two important needs for the UGTA project. First, the data set compiled for this task serves as a repository for groundwater geochemical data pertaining to the PM-CAUs. Second, the geochemical investigations are focused on developing chemical and isotopic methodologies that can be used to independently verify UGTA hydrologic flow and transport modeling efforts. This type of characterization work is vital to our understanding of the fate and transport of contaminants in the subsurface environment.

Geochemical and isotopic data in the Oasis Valley flow system are consistent with a direct groundwater flowpath between Pahute Mesa and Oasis Valley. This result is corroborative with hydraulic gradients and the hydrogeologic framework of the area. The geochemical data indicate that groundwater discharge in central Oasis Valley consists predominantly of deep groundwater flow beneath Pahute Mesa mixed with a smaller amount of local recharge. The chemical and isotopic composition of groundwater in the Oasis Valley discharge area is further affected by shallow groundwater recirculation and gas exchange through the unsaturated zone. The data also suggest that groundwater in northwestern Oasis Valley originates from north of Oasis Valley, and that groundwater from southeastern Pahute Mesa flows both into the Beatty Wash area of Oasis Valley and down Fortymile Canyon.

Fracture-coating mineral phases for 23 archived samples from six drill holes in the Pahute Mesa area were analyzed using micrographic and isotopic techniques. The fracture-coating mineral-phase information is needed to constrain geochemical models for examining potential flowpaths and calculating groundwater travel times. Phases observed on fractures include: widespread calcite, mixed illite/smectite, quartz, feldspars, zeolites, and Fe- and Mnoxyhydroxides, with more localized pyrite, chlorite, and epidote. Fracture-coating calcites in the volcanic rock aquifers have carbon-13 $\left(\delta^{13} \mathrm{C}\right)$ signatures that suggest a carbon source derived from Paleozoic carbonate rocks that typically underlie the volcanic rocks in this region. Calcite oxygen-18 $\left(\delta^{18} \mathrm{O}\right)$ values reflect deposition from hydrothermal or geothermal fluids at temperatures locally as high as $170^{\circ} \mathrm{C}$. 
Cool-season precipitation is the predominant source of recharge to shallow/perched NTS groundwater and to springs in the Kawich and Cactus ranges north of the NTS, as shown by deuterium $(\delta \mathrm{D})$ and $\delta^{18} \mathrm{O}$ precipitation weighted-mean values of warm- and cool-season precipitation. Tritium activities show that shallow/perched NTS groundwater and springs in the Kawich and Cactus ranges have been recharged within the last 50 years. Comparison of $\delta \mathrm{D}$ and $\delta^{18} \mathrm{O}$ values of recent recharge with those of deep groundwater in the study area reveals that Pahute Mesa and Oasis Valley groundwaters originated either (1) during a past, cooler climatic period than present conditions (which would suggest relatively short flowpaths and long travel times between proximal recharge and local discharge areas), or (2) from recharge at higher elevations and latitudes than Pahute Mesa (which would suggest relatively long flowpaths and short travel times between distal recharge and local discharge areas). Both of these issues are significant in that they define end-member possibilities for recharge amounts and distribution as well as travel times. Deuterium and $\delta^{18} \mathrm{O}$ measurements for groundwater in aquifers throughout southern Nevada strongly indicate groundwater recharge during a past, cooler climatic period are not evident, with the possible exception of a few isolated pockets. Thus, these data support long flowpaths (from north of the Pahute Mesa-Oasis Valley area to Oasis Valley) and fast travel times between northern recharge areas and Pahute Mesa and Oasis Valley. Additionally, $\delta \mathrm{D}$ and $\delta^{18} \mathrm{O}$ measurements provide strong evidence for direct groundwater flow between Pahute Mesa and Oasis Valley.

Tritium was not observed in a majority of the groundwaters sampled during this study, indicating that most deep groundwaters do not contain a significant component of young water ( $<50$ years old). Relatively high tritium activities were observed only in wells UE-29a\#1 and \#2 in Fortymile Canyon. Groundwater samples from these wells have tritium-helium ages of less than 10 years. Helium isotope $\left({ }^{3} \mathrm{He},{ }^{4} \mathrm{He}\right)$ data reveal a significant component of mantle-derived ${ }^{3} \mathrm{He}$ in many of the Oasis Valley groundwaters. The mantle-derived helium likely originated from gas diffusing upward from the deep crust or upper mantle along faults. The ${ }^{4} \mathrm{He}$ concentrations in groundwater in Oasis Valley and Pahute Mesa tend to correlate with ${ }^{3} \mathrm{He}$ concentrations - i.e., high ${ }^{4} \mathrm{He}$ values are generally associated with groundwater that also contains high ${ }^{3} \mathrm{He}$. In groundwaters containing low ${ }^{3} \mathrm{He}$ concentrations (e.g., U-20 WW), the observed concentrations of ${ }^{4} \mathrm{He}$ suggest that groundwater residence times are less than 10,000 years.

Dissolved inorganic carbon in groundwater in the volcanic rock aquifers shows a general trend toward decreasing ${ }^{14} \mathrm{C}$ values and increasing $\delta{ }^{13} \mathrm{C}$ values. This trend indicates water-rock interaction between groundwater and old $\left({ }^{14} \mathrm{C}\right.$-absent $)$ carbonate minerals. In contrast, groundwater ${ }^{14} \mathrm{C}$ values increase in the Oasis Valley discharge area, indicating mixing of regional groundwater with a young recharge component, and/or open system reactions with $\mathrm{CO}_{2}$ and young carbonate minerals in the soil or unsaturated zone. Water-rock interaction and matrix diffusion effects require measured ${ }^{14} \mathrm{C}$ values to be corrected for these reactions to obtain a groundwater age. Thus, to determine mean aquifer residence times and groundwater travel times, a geochemical modeling approach is needed to account for the water-rock interaction and diffusion effects.

Trace element, strontium $\left(\delta^{87} \mathrm{Sr}\right)$ isotope, and uranium $\left({ }^{234} \mathrm{U} /{ }^{238} \mathrm{U}\right)$ isotope data are useful indicators of groundwater flowpaths and water-rock interactions along these paths. Analysis of the trace element data shows an increasing concentration gradient for conservative trace elements between Pahute Mesa and Oasis Valley, which is consistent with groundwater flow from Pahute Mesa to Oasis Valley. Additionally, $\delta^{87} \mathrm{Sr}$ values generally decrease from Pahute Mesa to Oasis 
Valley, reflecting groundwater interaction with low $\delta^{87} \mathrm{Sr}$ volcanic rock. Uranium concentrations are anomalously high in Oasis Valley groundwaters as compared to most groundwaters in southern Nevada. Variations in groundwater ${ }^{234} \mathrm{U} /{ }^{238} \mathrm{U}$ activity ratios, and a positive correlation between uranium and sodium concentrations, provide further evidence for water-rock interaction with felsic volcanic rocks. The trace element, $\delta^{87} \mathrm{Sr}$, and ${ }^{234} \mathrm{U} /{ }^{238} \mathrm{U}$ data suggest a complex flowpath history, involving multi-step, water-rock interactions with both silicate rock and carbonate minerals, cation exchange between groundwater and zeolitic aquifer rock, open-system reactions in the discharge area, and mixing with young recharge water. These data also indicate that southern Oasis Valley groundwaters contain a component of groundwater flow from the Beatty Wash area.

Chlorofluorocarbons (CFCs) were observed in all well and spring waters sampled during this study. The presence of CFCs in tritium-free groundwaters is interpreted to result from atmospheric gases that have diffused through the unsaturated zone into the groundwater or that were introduced during well drilling, development, or sampling. The diffusion of CFCs through the unsaturated zone is consistent with the open-system processes inferred for the central part of Oasis Valley.

Geochemical modeling results are consistent with groundwater flow from Pahute Mesa to Oasis Valley. Changes in observed major-ion chemistry can be modeled by geochemical reactions with the average chemical and isotopic compositions of minerals and volcanic glass identified in the aquifer. Geochemical models for Oasis Valley discharge that best fit the constraining assumptions involve a mixture of deep groundwater beneath Pahute Mesa with a smaller amount of local recharge, together with shallow recirculated groundwater in Oasis Valley (or gas exchange through the unsaturated zone in Oasis Valley), and/or groundwater underflow from north of the Pahute Mesa-Oasis Valley area. Groundwater flow from north of Oasis Valley to northwestern Oasis Valley, from southeastern Pahute Mesa to the Beatty Wash area of Oasis Valley, or down Fortymile Canyon also has viable model solutions. Most of these models require the input of local recharge water mixing with Pahute Mesa groundwater to obtain a solution that meets the constraining assumptions. Geochemical modeling is limited by: the small amount of solid-phase data (which presently exist only for boreholes on Pahute Mesa); the lack of groundwater samples with complete chemical and isotopic data north of Oasis Valley and Pahute Mesa; limited ${ }^{13} \mathrm{C}$ data for fracture-coating calcite in the saturated zone; and an incomplete understanding of carbon isotope diffusion processes.

Travel times calculated for Oasis Valley groundwater, using geochemical models to account for the addition and removal of inorganic carbon, range from modern (greater than 50 years) to 8,500 years. Oasis Valley groundwater ages were also estimated from carbon isotope analyses of dissolved organic carbon (DOC). DOC groundwater ages range from modern to 6,800 years. Groundwater ${ }^{14} \mathrm{C}$ model ages can be further constrained by taking into account the observed differences in groundwater chemical and isotopic compositions for samples from different parts of Oasis Valley and the different mixtures of groundwater. Model-calculated groundwater ages indicate that travel times to Oasis Valley from Pahute Mesa, for a mixture of waters, range from 1,900 to 6,200 years. DOC-estimated ages for groundwater at the end of this flowpath range from 1,700 to 6,800 years. Model-calculated travel times from southeast Pahute Mesa to the Beatty Wash area in Oasis Valley and DOC-estimated ages for samples from the Beatty Wash area range from 2,600 to 4,200 years. Travel times from southeast Pahute Mesa to Well J-13 in Fortymile Wash range from 2,900 to 4,200 years. Model-calculated travel times for 
groundwater transport from north of Oasis Valley into northwestern Oasis Valley are approximately 1,500 years. The DOC-estimated age for groundwater in northwestern Oasis Valley is also about 1,500 years. In general, model-calculated travel times and DOC-estimated groundwater ages indicate that groundwater travel time from Pahute Mesa to Oasis Valley is in the range of about 2,000 to 6,000 years.

\section{REFERENCES}

Al-Aasm, I.S., B.E. Taylor and B. South, 1990. Stable isotope analysis of multiple carbonate samples using selective acid extraction. Chem. Geol., 80:119-125.

Andrews, J.N. and D.J. Lee, 1979. Inert gas in groundwater from the Bunter sandstone of England as indicators of age and palaeoclimatic trends. Jour. Hydrol., 41:233-252.

Benson, L. and H. Klieforth, 1989. Stable isotopes in precipitation and groundwater in the Yucca Mountain region, southern Nevada: Paleoclimatic implications. in Aspects of Climate Variability in the Pacific and the Western Americas, American Geophysical Union, Geophysical Monograph 55, D.H. Peterson (ed.), p. 41-59.

Benson, B.B. and D. Krause, Jr., 1976. Empirical laws for dilute aqueous solutions of nonpolar gases. Jour. Chem. Phys., 64:689-709.

Benson, L.V. and P.W. McKinley, 1985. Chemical composition of ground water in the Yucca Mountain area, Nevada, 1971-84. U.S. Geological Survey Open-File Report 85-484, 10 p.

Bigeleisen, J., M.L. Perlman and H. Prosser, 1952. Conversion of hydrogenic materials to hydrogen for isotopic analysis. Anal. Chem., 24:1356-1357.

Blankennagel, R.K. and J.E. Weir, Jr., 1973. Geohydrology of the eastern part of Pahute Mesa, Nevada Test Site, Nye County, Nevada: U.S. Geological Survey Professional Paper 712-B, $35 \mathrm{p}$.

Bottinga, Y., 1969. Calculated fractionation factors for carbon and hydrogen isotope exchange in the system calcite-carbon dioxide-graphite-methane-hydrogen-water vapor. Geochim. Cosmochim. Acta, 33, 49-64.

Boughton, C.J., 1986. Integrated geochemical and hydraulic analysis of Nevada Test Site ground water systems. M.S. Thesis, University of Nevada, Reno.

Brikowski, T.H., 1994. Stagnant perched water at Pahute Mesa, Nevada Test Site: A pointdilution test in a large diameter borehole. EOS, 75, 250 (abstract).

Brikowski, T.H., J. Chapman, B. Lyles and S. Hokett, 1993. Origin of elevated water levels encountered in Pahute Mesa emplacement boreholes: Preliminary investigations. Water Resources Center, Desert Research Institute, Publication \#45123, 22 p.

Brown, C.E., 1998. Applied Multivariate Statistics in Geohydrology and Related Sciences. Springer-Verlag, Berlin.

Busenberg, E. and L.N. Plummer, 1992. Use of chlorofluorocarbons $\left(\mathrm{CCl}_{3} \mathrm{~F}\right.$ and $\left.\mathrm{CCl}_{2} \mathrm{~F}_{2}\right)$ as hydrologic tracers and age-dating tools: the alluvium and terrace system of central Oklahoma. Water Resour. Res., 28:2257-2283. 
Busenberg, E., E.P. Weeks, L.N. Plummer and R.C. Bartholomay, 1993. Age dating ground water by use of chlorofluorocarbons $\left(\mathrm{CCl}_{3} \mathrm{~F}\right.$ and $\left.\mathrm{CCl}_{2} \mathrm{~F}_{2}\right)$, and distribution of chlorofluorocarbons in the unsaturated zone, Snake River Plain, Idaho National Engineering Laboratory, Idaho. U.S. Geological Survey Water-Resources Investigation Report 93-4054, $47 \mathrm{p}$.

Byers, F.M. Jr., W.J. Carr and P.P. Orkild, 1989. Volcanic centers of southwestern Nevada: Evolution of understanding, 1960-1988. Jour. Geophys. Res. 94:5908-5924.

Carothers, W.W. and Y.K. Kharaka, 1980. Stable carbon isotopes of $\mathrm{HCO}_{3}{ }^{-}$in oil-field waters implications for the origin of $\mathrm{CO}_{2}$. Geochim. Cosmochim. Acta, 44:323-332.

Carr, W.J., 1990. Styles of extension in the Nevada Test Site region, southern walker Lane Belt: An integration of volcano-tectonic and detachment fault models. Geol. Soc. Am. Memoir, 176: 283-303.

Cerling, T.E., 1984. The stable isotopic composition of modern soil carbonate and its relationship to climate. Earth Planet. Sci. Lett., 71:229-240.

Chapman, J.B. B.F. and Lyles, 1993. Groundwater chemistry at the Nevada Test Site: Data and preliminary interpretations. Water Resources Center, Desert Research Institute, Publication No. 45100,45 p.

Christiansen, R.L., P.W. Lipman, W.J. Carr, F.M. Byers, Jr., P.P. Orkild and K.A. Sargent, 1977. Timber Mountain - Oasis Valley caldera complex of southern Nevada. Geol. Soc. Am. Bull. 88:943-959.

Claassen, H.C. and A.F. White, 1979. Application of geochemical kinetic data to ground-water systems, Part I, A tuffaceous-rock system in southern Nevada, in Chemical Modeling in Aqueous Systems: American Chemical Society Symposium Series 93, E. A. Jenne, ed., pp. 771-793.

Claassen, H.C., 1985. Sources and mechanisms of recharge for ground water in the west-central Amargosa Desert, Nevada - A geochemical interpretation. U.S. Geological Survey Professional Paper 712F. 31 p.

Cook, P.G. and D.K. Solomon, 1995. The transport of atmospheric trace gases to the water table: implications for groundwater dating with chlorofluorocarbons and Krypton-85. Water Resour. Res., 31:263-270.

Cook, P.G., D.K. Solomon, L.N. Plummer, E. Busenberg and S.L. Schiff, 1995. Chlorofluorocarbons as tracers of groundwater transport processes in a shallow, silty sand aquifer. Water Resour. Res., 31:425-434.

Coplen, T.B., C. Kendall and J. Hopple, 1983. Comparison of stable isotope reference samples. Nature, 302:236-238.

Cornwall, H.R. 1972. Geology and Mineral Deposits of Southern Nye County, Nevada. Nevada Bureau of Mines and Geology and U.S. Geological Survey, Nevada Bureau of Mines and Geology Bulletin 77.

Craig, H., 1961. Isotopic variations in meteoric waters. Science, 133:1702-1703. 
Cummings, D., 1968. Mechanical analysis of the effect of the Timber Mountain caldera on basin and range faults. Jour. Geophys. Res., 73:2787-2794.

Dansgaard, W., 1964. Stable isotopes in precipitation. Tellus, 16:436-468.

Davisson, M.L., J.M. Kenneally, D.K. Smith, G.B. Hudson, G.J. Nimz and J.H. Rego, 1994. Preliminary report on the isotope hydrology investigations at the Nevada Test Site: Hydrologic resources management program FY 1992-1993. Lawrence Livermore National Laboratory, Nuclear Chemistry Division, UCRL-ID-116122.

Davisson, M.L., D.K. Smith, J. Kenneally and T.P. Rose, 1999. Isotope hydrology of southern Nevada groundwater: Stable isotopes and radiocarbon. Water Resour. Res., 35:279-294.

Drellack, S.L., Jr., L.B. Prothro, K.E. Roberson, B.A. Schier and E.H. Price. 1997. Analysis of Fractures in Volcanic Cores from Pahute Mesa, Nevada Test Site. Bechtel Nevada, DOE/NV/11718-160, UC-703.

Drever, J.I., 1982. The Geochemistry of Natural Waters. Prentice-Hall, Inc, Englewood Cliffs, N.J.

Dugan, J.P., J. Borthwick, R.S. Harmon, M.A. Gagnier, J.E. Gahn, E.P. Kinsel, S. Macleod, J.A. Viglino and J.W. Hess, 1985. Guanidine hydrochloride method for determination of water oxygen isotope ratios and the oxygen-18 fractionation between carbon dioxide and water at $25^{\circ} \mathrm{C}$. Anal. Chem., 57:1734-1736.

Dunkle, S.A., L.N. Plummer, E. Busenberg, P.J. Phillips, J.M. Denver, P.A. Hamilton, R.L. Michel and T.B. Coplen, 1993. Chlorofluorocarbons $\left(\mathrm{CCl}_{3} \mathrm{~F}\right.$ and $\left.\mathrm{CCl}_{2} \mathrm{~F}_{2}\right)$ as dating tools and hydrologic tracers in shallow groundwater of the Delmarva Peninsula, Atlantic Coastal Plain, United States. Water Resour. Res., 29:3837-3860.

Edmunds, W. M. and P.L. Smedley, 2000. Residence time indicators in groundwater: The East Midlands Triassic sandstone aquifer. Appl. Geochem., 15:737-752.

Edmunds, W. M., J.J. Carrillo-Rivera and A. Cardona, 2002. Geochemical evolution of groundwater beneath Mexico City. J. Hydrol., 258:1-24.

E.B. Ekren, R.E. Anderson, C.L. Rogers and D.C. Noble. 1971. Geology of Northern Nellis Air Force Bombing and Gunnery Range, Nye County, Nevada. U.S. Geological Survey and U.S. Atomic Energy Comission, USGS Professional Paper 651.

Ekwurzel, B., P. Schlosser, W.M. Smethie, Jr., L.N. Plummer, E. Busenberg, R.L. Michel, R. Weppernig and M. Stute, 1994. Dating of shallow groundwater: Comparison of the transient tracers ${ }^{3} \mathrm{H} /{ }^{3} \mathrm{He}$, chlorofluorocarbons, and ${ }^{85} \mathrm{Kr}$. Water Resour. Res., 30:1693-1708.

Farnham I.M., K.J. Stetzenbach, A.K. Singh and K.H. Johannesson, 2000. Deciphering groundwater flow systems in Oasis Valley, Nevada, using trace lement chemistry, multivariate statistics, and GIS. Math. Geol., 32(8):943-968.

Ferguson, J.F., A.H. Cogbill and R.G. Warren, 1994. A geophysical and geological transect of the Silent Canyon caldera complex, Pahute Mesa, Nevada. Jour. Geophys. Res., 99 :43234339. 
Fontes, J.Ch., 1980. Environmental isotopes in groundwater hydrology. In P. Fritz and J.Ch. Fontes, (eds.), Handbook of Environmental Isotope Geochemistry, Volume 1, The Terrestrial Environment, A. Elsevier, Amsterdam, pp. 75-140.

Fontes, J.Ch., 1983. Dating of groundwater. In Guidebook on Nuclear Techniques in Hydrology. IAEA Technical Reports Series, no. 91, p. 285-317.

Friedman, I., G.I. Smith, J.D. Gleason, A. Warden and J.M. Harris, 1992. Stable isotope composition of waters in southeastern California. 1. Modern precipitation. Journal of Geophysical Research, 97(5D):5795-5812.

Frizzell, V.A. Jr. and J. Shulters, 1990. Geologic map of the Nevada Test Site, southern Nevada. U.S. Geological Survey, Miscellaneous Investigations Series, Map I-2046.

Gardner, G.G. and T.H. Brikowski, 1993. Origin of elevated water levels in emplacement holes, Pahute Mesa, Nevada Test Site: a numerical study. Water Resources Center, Desert Research Institute, Publication No. 45124, 22 p.

Gat, J.R., 1980. The isotopes of hydrogen and oxygen in precipitation. In P. Fritz and J.Ch. Fontes, (eds.), Handbook of Environmental Isotope Geochemistry, Volume 1, The Terrestrial Environment, A. Elsevier, Amsterdam, pp. 21-47.

Grauch, V.J.S., D.A. Sawyer, C.J. Fridrich and M.R. Hudson, 1997. Geophysical interpretations west of and within the northwestern part of the Nevada Test Site. U.S. Geological Survey Open-File Report 97-476, 45 p.

Harrill, J.R., J.S. Gates and J.M. Thomas, 1988. Major groundwater flow systems in the Great Basin region of Nevada, Utah, and adjacent states: U.S. Geological Survey Hydrologic Investigations Atlas HA-694-C, 2 sheets, scale 1:100,000.

Heaton, T.H.E. and J.C. Vogel, 1981. "Excess air” in groundwater. Jour. Hydrol., 50:201-216.

Hershey, R.L. and T.H. Brikowski, 1995. Continued investigations of the occurrence of water in Pahute Mesa emplacement holes. Water Resources Center, Desert Research Institute, Publication No. 45131, 12 p.

Hilton, D.R., 1996. The helium and carbon isotope systematics of a continental geothermal system: results from monitoring studies at Long Valley caldera (California, U.S.A.). Chem. Geol., 127:269-295.

Hingston, F.J., R.J. Atkinson, A.S. Posner and J.P. Quirk, 1967. The specific adsorption of anions. Nature, 215:1459-1461.

Houghton, J.G., 1969. Characteristics of rainfall in the Great Basin. Desert Research Institute, University of Nevada, Reno, 205 p.

Houghton, J.G., C.M. Sakamoto and R.O. Gifford, 1975. Nevada's weather and climate. Nevada Bureau of Mines and Geology Special Publication 2, p. 1-78.

Hudson, G.B., 1994. Natural and artificial noble gas hydrologic tracers. Lawrence Livermore National Laboratory Report, UCRL-ID-117543, 30 p.

Ingraham, N.L., B.L. Lyles, R.L. Jacobson and J.W. Hess, 1991. Stable isotopic study of precipitation and spring discharge in southern Nevada. J. Hydrol., 125:243-258. 
ISO, 1992. ISO 31-0, Quantities and Units, Part 0, General Principles, subclause 2.3.3. International Organization for Standardization.

IT Corporation, 1998. Summary of micrographic analysis of fracture-coating phases on drill cores from Pahute Mesa, Nevada Test Site. DOE/NV/13052-050. U.S. Department of Energy, Nevada Operations Office, Las Vegas, NV. September.

Johnston, C.T., P.G. Cook, S.K. Frape, L.N. Plummer, E. Busenberg and R.J. Blackport, 1998. Ground water age and nitrate distribution within a glacial aquifer beneath a thick unsaturated zone. Ground Water, 36:171-180.

Jolliffe, I.T., 1986. Principal Component Analysis. Springer-Verlag, New York.

Laczniak, R.J., J.C. Cole, D.A. Sawyer and D.A. Trudeau, 1996. Summary of hydrogeologic controls on groundwater flow at the Nevada Test Site, Nye County, Nevada. U.S. Geological Survey Water-Resources Investigations Report 96-4109, 59 p.

Lawrence Livermore National Laboratory, 1995. Underground Test Area Remedial Investigation/Feasibility Study, Standard Operating Procedures. Isotope Sciences Division, unpublished report.

Levin, I., K.O. Munnich and W. Weiss, 1980. The effect of anthropogenic $\mathrm{CO}_{2}$ and ${ }^{14} \mathrm{C}$ sources on the distribution of ${ }^{14} \mathrm{C}$ in the atmosphere. In M.Stuiver and R.S. Kra (eds.), Proceedings of the $10^{\text {th }}$ International ${ }^{14} \mathrm{C}$ Conference. Radiocarbon, 22:379-391.

Libby, W.F., 1955. Radiocarbon dating, $2^{\text {nd }}$ edition. University of Chicago Press, Chicago, 175 p.

Ludwig, K.R., Z.E. Peterman, K.R. Simmons and E.D. Gutentag, $1993 .{ }^{234} \mathrm{U} /{ }^{238} \mathrm{U}$ ratios as a ground water flow tracer, SW Nevada-SE California. In Conference on High-Level Radioactive Waste Management, $4^{\text {th }}$, Las Vegas, NV. Proceedings American Society of Civil Engineers, p. 1567-1572.

Lyles B.F., J. Edkins, R.L. Jacobson and J.W. Hess, 1990. Time-series analysis of ion and isotope geochemistry of selected springs of the Nevada Test Site, Nye County, Nevada. Water Resources Center, Desert Research Institute, Publication No. 45068, 121 p.

Malmberg, G.T. and T.E. Eakin, 1962. Groundwater appraisal of Sarcobatus Flat and Oasis Valley, Nye and Esmeralda Counties, Nevada: Nevada Department of Conservation and Natural Resources, Groundwater Resources - Reconnaissance Report 10, 39 p.

McCrea, J.M., 1950. On the isotopic chemistry of carbonates and a paleotemperature scale. Jour. Chem. Phys., 18:849-857.

Mckinley, P.W. and T.A. Oliver, 1994. Meteorological, stream-discharge, and water-quality data for water year 1992 from two small basins in central Nevada. U.S. Geological Survey OpenFile Report 94-456, 56 p.

Mckinley, P.W. and T.A. Oliver, 1995. Meteorological, stream-discharge, and water-quality data for 1986 through 1991 from two small basins in central Nevada. U.S. Geological Survey Open-File Report 93-651, 167 p.

McNichol, A.P., G.A. Jones, D.L. Hutton, A.R. Gagnon and R.M. Key, 1994. The rapid preparation of seawater $\Sigma \mathrm{CO}_{2}$ for radiocarbon analysis at the National Ocean Sciences AMS Facility. Radiocarbon, 36:237-246. 
Mifflin, M.D. and J.W. Hess, 1979. Regional carbonate flow systems in Nevada. Jour. Hydrol., 43:217-237.

Milne, W.K., L.V. Benson and P.W. McKinley, 1987. Isotope content and temperature of precipitation in southern Nevada, August 1983-August 1986. U.S. Geological Survey OpenFile Report 87-463, 32 p.

Mook, W.G., J.C. Bommerson and W.H. Staverman, 1974. Carbon isotope fractionation between dissolved bicarbonate and gaseous carbon dioxide. Earth Planet. Sci. Lett., 22:169-176.

Mook, W.G., 1980. Carbon-14 in hydrogeological studies. In P. Fritz and J.Ch. Fontes, (eds.), Handbook of Environmental Isotope Geochemistry, Volume 1, The Terrestrial Environment, A. Elsevier, Amsterdam, pp. 49-74.

Mook, W.G., 1986. ${ }^{13} \mathrm{C}$ in atmospheric $\mathrm{CO}_{2}$. Netherlands Journal of Sea Research, 20:211-223.

Newman, B.D., A.R. Campbell, D.I. Norman and D.B. Ringelberg, 1997. A model for microbially induced precipitation of vadose-zone calcites in fractures at Los Alamos, New Mexico, USA. Geochim. Cosmochim. Acta, 61:1783-1792.

O’Hagan, M.D. and R.J. Laczniak, 1996. Ground-water levels beneath eastern Pahute Mesa and vicinity, Nevada Test Site, Nye County, Nevada. U.S. Geological Survey, Water Resources Investigations Report 96-4042.

O'Neil, J.R., R.N. Clayton and T.K. Mayeda, 1969. Oxygen isotope fractionation in divalent metal carbonates. Jour. Chem. Physics, 51:5547-5558.

O'Nions, R.K. and E.R. Oxburgh, 1988. Helium, volatile fluxes and the development of continental crust. Earth Planet. Sci. Lett., 90:331-347.

Oster, H., C. Sonntag and K.O. Munnich, 1996. Groundwater age dating with chlorofluorocarbons. Water Resour. Res., 32:2989-3001.

Paces, J.B., L.A. Neymark, B.D. Marshall, J.F. Whelan and Z.E. Peterman, 1996. Ages and origins of subsurface secondary minerals in the exploratory studies facility (ESF). U.S. Geological Survey, Yucca Mountain Project Branch, 1996 Milestone Report 3GQH450M, 55 p.

Perfect, D.L., C.C. Faunt, W.C. Steinkampf and A.K. Turner. 1994. Hydrochemical database for the Death Valley region. U.S. Geological Survey Open File Report 94-305.

Peterman, Z.E., J.S. Stuckless, S.A. Mahan, B.D. Marshall, E.D. Gutentag and J.S. Downey, 1992. Strontium isotope characterization of the Ash Meadows ground-water system, southern Nevada, USA. In Kharaka, Y.K. and Maest, A.S. (eds.), Water-Rock Interaction. Proc. $7^{\text {th }}$ International Symposium Water-Rock Interaction, Park City, Utah, 13-18 July 1992, pp. 825829.

Plummer, L.N., E.C. Prestemon and D.L. Parkhurst, 1991. An interactive code (NETPATH) for modeling net geochemical reactions along a flowpath. U.S. Geological Survey WaterResources Investigations Report 91-4078, 94 p.

Plummer, L.N., R.L. Michel, E.M. Thurman and P.D. Glynn, 1993. Environmental tracers for age dating young ground water. In Alley, W.M. (ed.), Regional Ground-water Quality. Van Nostrand Reinhold, New York, p. 255-294. 
Plummer, L.N., E.C. Prestemon and D.L. Parkhurst, 1994, An interactive code (NETPATH) for modeling net geochemical reactions along a flowpath, version 2. U.S. Geological Survey Water-Resources Investigations Report 94-4169, 130 p.

Poreda, R.J., T.E. Cerling and D.K. Salomon, 1988. Tritium and helium isotopes as hydrologic tracers in a shallow unconfined aquifer. Jour. Hydrol., 103:1-9.

Prothro, L.B. and S.L. Drellack, Jr. 1997. Nature and extent of lava-flow aquifers beneath Pahute Mesa, Nevada Test Site. Bechtel Nevada, DOE/NV/11718-156.

Quade, J., T.E. Cerling and J.R. Bowman, 1989. Systematic variations in the carbon and oxygen isotopic composition of pedogenic carbonate along elevation transects in the southern Great Basin, United States. Geol. Soc. Am. Bull., 101:464-475.

Raker, S.L., 1987. Chemistry of groundwater in tuffaceous rocks, central Nevada. University of Nevada, Reno, unpublished Masters Thesis, 111 p.

Reed, W.P., 1992. Report of investigation, reference materials 8543-8546. National Institute of Standards and Technology Report, June 22, 1992, 3 p.

Reimus, P.W., M.J. Haga, S.D. Ware, A. Humphrey and D. Counce, 1998. Laboratory experiments to support interpretation of the BULLION forced-gradient experiment. Los Alamos National Laboratory Draft Report submitted to DOE September 10, 1998.

Reiner, S.R., R.J. Laczniak, G.A. DeMeo, J.L. Smith, P.E. Elliott, W.E. Nylund and C.J. Fridrich, 2002. Ground-water discharge determined from measurements of evapotranspiration, other available hydrologic components, and shallow water-level changes, Oasis Valley, Nye County, Nevada. U.S. Geological Survey Water-Resources Investigations Report 01-4239, 65 p.

Robledo, A.R., P.L. Ryder, J.M. Fenelon and F.L. Paillet, 1998. Geohydrology of monitoring wells drilled in Oasis Valley near Beatty, Nye County, Nevada, 1997: U.S. Geological Survey Water-Resources Investigations Report 98-4184, 40 p.

Rose, T.P., J.M. Kenneally, D.K. Smith, M.L. Davisson, G.B. Hudson and J.H. Rego, 1997. Chemical and isotopic data for groundwater in southern Nevada. Lawrence Livermore National Laboratory UCRL-ID-128000, 35 p.

Rose, T.P., M.L. Davisson, D.K. Smith and J.M. Kenneally, J.M. 1998a. Isotope hydrology investigation of regional groundwater flow in central Nevada. In D.K. Smith, ed., Hydrologic Resources Management Program and Underground Test Area Operable Unit FY 1997 Progress Report, Lawrence Livermore National Laboratory, UCRL-ID-130792, pp. 53-75.

Rose, T.P., J.M. Kenneally, G.B. Hudson, G.F. Eaton and D.K. Smith, D.K. 1998b. Tritium, helium and carbon isotopic data for groundwater from Oasis Valley and Pahute Mesa: FY98 analytical results. Report submitted to UGTA Operable Unit, U.S. Department of Energy, Nevada Operations Office, Las Vegas, NV. September.

Rose, T.P., F.C. Benedict, Jr. and G.F. Eaton. 1999. Stable isotope and radiocarbon compositions of secondary calcite from Pahute Mesa, Nevada Test Site. In D.K. Smith and G.F. Eaton (eds.) Hydrologic Resources Management Program and Underground Test Area FY 1998 Progress Report, Lawrence Livermore National Laboratory, UCRL-ID-135170, pp. 57-76. 
Rosenbaum, J. and S.M.F. Sheppard, 1986. An isotopic study of siderites, dolomites and ankerites at high temperatures. Geochim. Cosmochim. Acta, 50:1147-1150.

Rubinson, M. and R.N. Clayton, R.N. 1969. Carbon-13 fractionation between aragonite and calcite. Geochim. Cosmochim. Acta, 33:997-1002.

Russell, C.E., 1987. Hydrogeologic investigations of flow in fractured tuffs, Rainier Mesa, Nevada Test Site. University of Nevada, Las Vegas, unpublished Masters Thesis, 154 p.

Sadler, W.R., 1990. A deuterium-calibrated, discrete-state compartment model of regional groundwater flow, Nevada Test Site and Vicinity. University of Nevada, Reno, unpublished Masters Thesis, $249 \mathrm{p}$.

Salomons, W. and W.G. Mook, 1986. Isotope geochemistry of carbonates in the weathering zone. In P. Fritz and J.Ch. Fontes, eds., Handbook of Environmental Isotope Geochemistry, Volume 2, The Terrestrial Environment, B. Elsevier, Amsterdam, pp. 239-269.

Sass, J.H., A.H. Lachenbruch and C.W. Mase, C.W. 1980. Analysis of thermal data from drill holes UE25a-3 and UE-25a-1, Calico Hills and Yucca Mountain, Nevada Test Site. U.S. Geological Survey Open-File Report 80-826, 25 p.

Schlosser, P., 1992. Tritium $/{ }^{3}$ He dating of waters in natural systems. In Isotopes of Noble Gases as Tracers in Environmental Studies. IAEA, Vienna, pp. 123-145.

Schoff, S.L. and J.E. Moore, J.E. 1964. Chemistry and movement of ground water, Nevada Test Site. U.S. Geological Survey, Report TEI-838, 75 p.

Singh, A., 1996. Outliers and robust procedures in some chemometric applications. Chemometrics and Intelligent Laboratory Systems, 33:75-100.

Singh, A, A.K. Singh and G. Flatman, 1994. Estimation of background levels of contaminants. Mathematical Geology, 26:361-388.

Smith, D.K., T.P. Rose, M.L. Davisson, G.B. Hudson, S. Niemeyer and A.E. Moeller, 1998. Volatile and fluid transport in deep, arid soils. Lawrence Livermore National Laboratory, UCRL-ID-129653, 10 p.

Sorey, M.L., W.C. Evans, B.M. Kennedy, C.D. Farrar, L.J. Hainsworth and B. Hausback, 1998. Carbon dioxide and helium emissions from a reservoir of magmatic gas beneath Mammoth Mountain, California. Jour. Geophys. Res., 103:15,303-15,323.

STATISTICA for Windows Vol III: Statistics II, 2nd Edition, StatSoft Inc., 3197-3234, 1995.

Stetzenbach, K.J., M. Amano, D.K. Kreamer and V.F. Hodge, V.F. 1994. Testing the limits of ICP-MS: determination of trace elements in ground water at the parts-per-trillion level. Ground Water, 32:976-985.

Stuiver, M. and H. Polach, 1977. Reporting of ${ }^{14} \mathrm{C}$ data. Radiocarbon, 19:355-363.

Surano, K.A., G.B. Hudson, R.A. Failor, J.M. Sims, R.C. Holland, S.C. MacLean. and J.C. Garrison, 1992. Helium-3 spectrometry for low-level tritium analysis of environmental samples. J. Radioanal. Nuclear Chem. Articles, 161:443-453.

Szabo, B.J. and T.K. Kyser, 1990. Ages and stable isotope compositions of secondary calcite and opal in drill cores from Tertiary volcanic rocks of the Yucca Mountain area, Nevada. Geol. Soc. Am. Bull., 102, 1714-1719. 
Szabo, Z., D.E. Rice, L.N. Plummer, E. Busenberg, S. Drenkard. And P. Schlosser, 1996. Age dating of shallow groundwater with chlorofluorocarbons, tritium/helium-3, and flowpath analysis, southern New Jersey coastal plain. Water Resour. Res., 32:1023-1038.

Thomas, J.M.,1996. Geochemical and isotopic interpretation of groundwater flow, geochemical processes and age dating of groundwater in the carbonate-rock aquifers of the southern Basin and Range. University of Nevada, Reno, unpublished Ph.D. thesis, 135 p.

Thomas, J.M., A.H. Welch and M.D. Dettinger, 1996. Geochemistry and isotope hydrology of representative aquifers in the Great Basin region of Nevada, Utah and adjacent states. U.S. Geological Survey Professional Paper 1409-C, 100 p.

Thorstenson, D.C., E.P. Weeks, H. Haas, E. Busenberg, L.N. Plummer and C.A. Peters, 1998. Chemistry of unsaturated zone gases sampled in open boreholes at the crest of Yucca Mountain, Nevada: Data and basic concepts of chemical and physical processes in the mountain. Water Resour. Res., 34(6):1507-1529.

Torgersen, T. and G.N. Ivey, 1985. Helium accumulation in groundwater. II: A model for the accumulation of the crustal ${ }^{4} \mathrm{He}$ degassing flux. Geochim. Cosmochim. Acta, 49:2445-2452.

U.S. Department of Energy. 1997. Regional groundwater flow and tritium transport monitoring and risk assessment of the underground test area, Nevada Test Site, Nevada. U.S. Department of Energy, Nevada Operations Office, Environmental Restoration Division, DOE/NV-477, Las Vegas, NV.

Vogel, J.C., L. Thilo and M. Van Dijken, 1974. Determination of groundwater recharge with tritium. J. Hydrol., 23:131-140.

Vogel, J.S., J.R. Southon. and D.E. Nelson, 1987. Catalyst and binder effects in the use of filamentous graphite for AMS. Nuclear Instruments and Methods in Physics Research, B29, $50-56$.

Wackernagel, H., 1995. Multivariate Geostatistics. Springer-Verlag, Berlin.

Walker, F.W., J.R. Parrington and F. Feiner, 1989. Nuclides and isotopes. General Electric Co. Nuclear Energy Operations, San Jose, California, 57 p.

Warren, R.G., D.A. Sawyer, F.M. Byers, Jr. and G.L. Cole, 1998. A petrographic/geochemical database and structural framework for the southwestern Nevada volcanic field. Los Alamos National Laboratory, CD ROM.

Warren, R.G., 1994. Structural elements and hydrogeologic units of the southwestern Nevada volcanic field. Informal document contained in: DOE 1997. Regional groundwater flow and tritium transport monitoring and risk assessment of the underground test area, Nevada Test Site, Nevada. U.S. Department of Energy, Nevada Operations Office, Environmental Restoration Division, DOE/NV-477, Las Vegas, NV.

Weeks, E.P., D.E. Earp and G.M. Thompson, 1982. Use of atmospheric fluorocarbons F-11 and F-12 to determine the diffusion parameters of the unsaturated zone in the southern high plains of Texas. Water Resour. Res., 18, 1365-1378.

Welhan, J.A., R.J. Poreda, W. Rison and H. Craig, 1988. Helium isotopes in geothermal and volcanic gases of the western United States, 1. Regional variability and magmatic origin. Jour. Volcanol. Geotherm. Res., 34:185-199. 
Whelan, J.F. and J.S. Stuckless, 1992. Paleohydrologic implications of the stable isotopic composition of secondary calcite within the Tertiary volcanic rocks of Yucca Mountain, Nevada. In Proceedings of the Third International Conference on High Level Radioactive Waste Management, April 12-16, 1992, Las Vegas, NV, pp. 1572-1581.

Whelan, J.F., R.J. Moscati and S.B.M. Allerton, 1995. Stable isotopic composition of precipitation at Yucca Mountain and the surrounding regions - February 1993 to February 1995. U.S. Geological Survey milestone report 3GCR510M to Department of Energy Yucca Mountain Project, Accession \#MOL.19960220.0022, 36 p.

White, A.F., 1979. Geochemistry of ground water associated with tuffaceous rocks, Oasis Valley, Nevada: U.S. Geological Survey Professional Paper 712-E, 25 p.

White, A.F. and N.J. Chuma, 1987. Carbon and isotopic mass balance models of Oasis ValleyFortymile Canyon groundwater basin, southern Nevada. Water Resour. Res., 23(4): 571-582.

White, A.F., H.C. Claassen and L.V. Benson, 1980. The effect of dissolution of volcanic glass on the water chemistry in a tuffaceous aquifer, Rainer Mesa, Nevada: U.S. Geological Survey Water-Supply Paper 1535-Q, 34 p.

Winograd, I.J. and W. Thordarson, 1975. Hydrogeologic and hydrochemical framework south-central Great Basin, Nevada-California, with special reference to the Nevada Test Site. U.S. Geological Survey Professional Paper 712-C, 126 p.

Winograd, I.J. and F.J. Pearson, Jr., 1976. Major carbon-14 anomaly in a regional carbonate aquifer: Possible evidence for megascale channeling, south central Great Basin. Water Resour. Res., 12:1125-1143.

Winograd, I.J. and F.N. Robertson, 1982. Deep oxygenated ground water: Anomaly or common occurrence? Science, 216:1227-1230.

Winograd, I.J., A.C. Riggs and T.B. Coplen, 1998. The relative contributions of summer and cool-season precipitation to groundwater recharge, Spring Mountains, Nevada, USA. Hydrogeology Journal, 6(1):77-93.

Wold, S., K. Esbensen and P. Geladi, 1987. Principal component analysis. Chemometrics and Intelligent Laboratory Systems, 2:37-52.

Yang, I.C., G.W. Rattray and P.Yu, 1996. Interpretation of chemical and isotopic data from boreholes in the unsaturated zone at Yucca Mountain, Nevada. U.S. Geological Survey Water-Resources Investigations Report 96-4058, 58 p. 